\title{
Carbon and Mineral Transformations in Seafloor Serpentinization Systems
}

by

Niya Gueorguieva Grozeva

B.S., Stony Brook University, 2011

Submitted in partial fulfillment of the requirements for the degree of

Doctor of Philosophy

at the

MASSACHUSETTS INSTITUTE OF TECHNOLOGY

and the

WOODS HOLE OCEANOGRAPHIC INSTITUTION

February 2018

(C) 2018 Niya G. Grozeva. All rights reserved.

The author hereby grants to MIT and WHOI permission to reproduce and to distribute publicly paper and electronic copies of this thesis document in whole or in part in any medium now known or hereafter created.

Signature of Author

Joint Program in Oceanography/Applied Ocean Science and Engineering Massachusetts Institute of Technology and Woods Hole Oceanographic Institution December 22, 2017

Certified by

Dr. Frieder Klein Thesis Co-Supervisor

Certified by Dr. Jeffrey S. Seewald Thesis Co-Supervisor

Accepted by

Dr. Mark D. Behn

Chair, Joint Committee for Geology and Geophysics Woods Hole Oceanographic Institution 


\title{
Carbon and Mineral Transformations in Seafloor Serpentinization Systems
}

\author{
by \\ Niya G. Grozeva \\ Submitted to the MIT/WHOI Joint Program in Oceanography/Applied Ocean Science \\ and Engineering on December 22, 2017 in partial fulfillment of the requirements \\ for the degree of Doctor of Philosophy in Geochemistry
}

\begin{abstract}
This thesis examines abiotic processes controlling the transformation and distribution of carbon compounds in seafloor hydrothermal systems hosted in ultramafic rock. These processes have a direct impact on carbon budgets in the oceanic lithosphere and on the sustenance of microorganisms inhabiting hydrothermal vent ecosystems. Where mantle peridotite interacts with carbon-bearing aqueous fluids in the subseafloor, dissolved inorganic carbon can precipitate as carbonate minerals or undergo reduction by $\mathrm{H}_{2(a q)}$ to form reduced carbon species. In Chapters 2 and 3 , I conduct laboratory experiments to assess the relative extents of carbonate formation and $\mathrm{CO}_{2}$ reduction during alteration of peridotite by $\mathrm{CO}_{2(a q)}$-rich fluids. Results from these experiments reveal that formation of carbonate minerals is favorable on laboratory timescales, even at high $\mathrm{H}_{2(a q)}$ concentrations generated by serpentinization reactions. Although $\mathrm{CO}_{2(a q)}$ attains rapid metastable equilibrium with formate, formation of thermodynamically stable $\mathrm{CH}_{4(a q)}$ is kinetically limited on timescales relevant for active fluid circulation in the subseafloor. It has been proposed that $\mathrm{CH}_{4}$ and potentially longer-chain hydrocarbons may be sourced, instead, from fluid inclusions hosted in plutonic and mantle rocks. Chapter 4 analyzes $\mathrm{CH}_{4}$-rich fluid inclusions in olivine-rich basement rocks from the Von Damm hydrothermal field and the Zambales ophiolite to better understand the origin of abiotic hydrocarbons in ultramaficinfluenced hydrothermal systems. Comparisons of hydrocarbon abundances and stable isotopic compositions in fluid inclusions and associated vent fluids suggest that fluid inclusions may provide a significant contribution of abiotic hydrocarbons to both submarine and continental serpentinization systems.
\end{abstract}

Thesis Co-supervisor: Dr. Frieder Klein Title: Associate Scientist, Woods Hole Oceanographic Institution

Thesis Co-supervisor: Dr. Jeffrey S. Seewald

Title: Senior Scientist, Woods Hole Oceanographic Institution 


\section{Acknowledgements}

First and foremost, I would like to thank my co-advisors, Frieder Klein and Jeff Seewald, for their scientific guidance and support over the past 5.5 years. Frieder was brave enough to take me on as his first Ph.D. student. And while I was far from the perfect student, Frieder's boundless enthusiasm and encouragement to explore new problems have helped me grow as both a scientist and a person. He has always been willing to keep his door open and answer any question, no matter how big or small, at all hours of the day. Jeff has been a constant source of wisdom, creativity, and positivity toward all obstacles (be they science- or boat-related), particularly with his sage advice to "work as little as possible, but still do good work." I will whole-heartedly attempt to follow this guidance as much as possible in my future career and life.

Many thanks to my defense chair, Chris German, and my committee members, Susan Humphris and Shuhei Ono, for their constructive comments and critical questions that improved this thesis. I would like to express my sincerest thanks to Sean Sylva for his inexhaustible technical expertise in the lab and for conducting some of the fluid analyses presented in this thesis. Without him, I would undoubtedly still be wondering where the power button is on the gas chromatograph. I am also indebted to Emmanuel Codillo and Karmina Aquino for collecting and performing analyses on samples in Chapter 4. Jill McDermott's doctoral research on the Von Damm hydrothermal field laid the essential groundwork for the exploration of $\mathrm{CH}_{4}$-rich fluid inclusions at this site. Many other individuals have contributed their scientific and technical expertise to this work, including Mark Kurz, Joshua Curtice, Carl Johnson, Eoghan Reeves, Maurice Tivey, Margaret Sulanowska, Neel Chatterjee, and Jim Eckert. I am especially grateful to the administrative talents at WHOI and MIT, including Eilean Kozak, Andrew Daly, Meg Tivey, Julia Westwater, Leanor Fraser, Christine Charette, Ronni Schwarz, Kris Kipp, Jim Yoder, and everyone in the Academic Programs Office who keeps the Joint Program running smoothly in the background. Finally, none of this would have been possible without the encouragement of Meg Tivey, who first introduced me to the world of seafloor hydrothermal vents at WHOI when I was a young and impressionable summer student fellow.

Needless to say, completing a Ph.D. would not have been nearly as tolerable without all the fantastic friends I have made at both WHOI and MIT. Above all, I am tremendously lucky to have shared my grad school experience with Erin Black. I could not have asked for a more supportive friend, colleague, and (briefly) housemate. Thank you to Net Charoenpong for bringing all manners of desserts to Fye (via Jen Karolewski) and commiserating with me on the state of the ion chromatograph. To my former officemates, Alex Mitchell and Max Collinet thank you for letting me sleep awkwardly on the office couch at all hours of the day (and sometimes night). I will sorely miss all the great times shared with (in no particular order) Christopher Kinsley, Ben Mandler, Elena Steponaitis, Jaap Nienhuis, Kate French, Deepak Cherian, Dan Amrhein, Melissa Moulton, Stephanie Brown, Yodit Tewelde, Mike Sori, Steve Messenger, Ben Klein, Aimee Gillespie, Sara Bosshart, Helen Feng, Danielle Gruen, Laura Stevens, Maja Edenius, Gabriela Farfan, Jay Brett, Sophie Chu, Lauren Kipp, Megan May, Jeff Kaeli, Mola the dog, and Mola's human, Carly Buchwald. Lastly, thanks to Ruel Jerry for giving me my name back. Coming from you, that means a lot. 
To my family - thank you for your unwavering and constant support over these past 5.5 years, and your equally constant nagging about when I will graduate. I know that one of you completed their doctoral research in less than 3 years. However, if there is anything I have learned from my work in geology, it is that numbers of the same order of magnitude are the same number.

Et finalement, à mon mari, Jean-Arthur Olive - thank you for always finding something new to be excited about in science and passing that infectious enthusiasm on to me. I would not have made it very far without your constant supply of French food, wine, bad geology disaster movies, and a willing ear to rant into.

This thesis research was funded by the National Science foundation through grants OCE1427274 and OCE-1634032. Louise Von Damm generously contributed financial support for research conducted in Chapter 4. Hopefully, we now know a little bit more about processes occurring at the Von Damm hydrothermal field and beyond. Funding for my first 4 years in graduate school was provided by fellowships from the National Science Foundation Graduate Research Fellowship Program (NSF-GRFP) and the WHOI Deep Ocean Exploration Institute (DOEI). The WHOI Academic Programs Office and MIT Student Assistance Fund provided financial support for conference travel. 
"What's wrong with scientists is that [they] do see wonder and beauty in everything."

- xkcd comic \#877 


\title{
Table of Contents
}

\begin{abstract}
$\begin{array}{lr}\text { Abstract } & 3\end{array}$
Acknowledgements $\quad 5$

List of Tables $\quad 12$

$\begin{array}{ll}\text { List of Figures } & 13\end{array}$
\end{abstract}

$\begin{array}{lr}\text { Chapter 1. Introduction } & 15\end{array}$

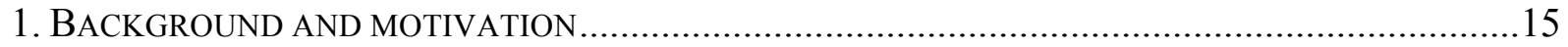

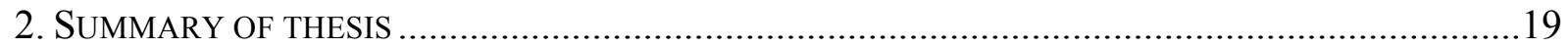

Chapter 2. Experimental study of carbonate formation in oceanic peridotite 27

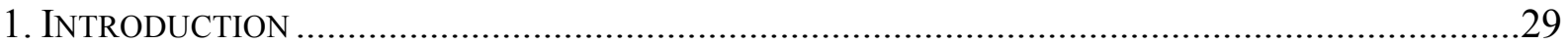

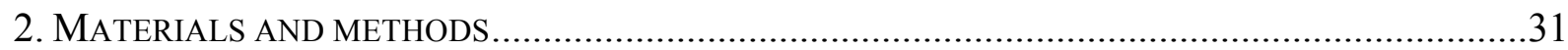

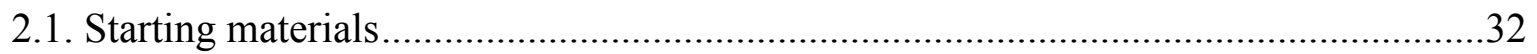

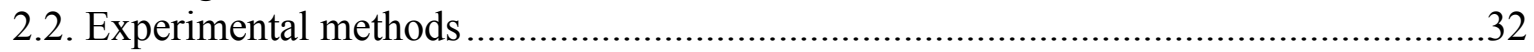

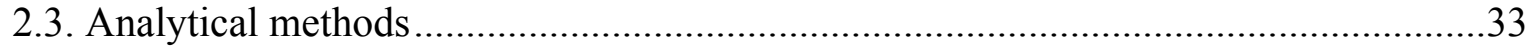

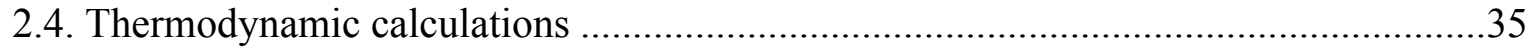

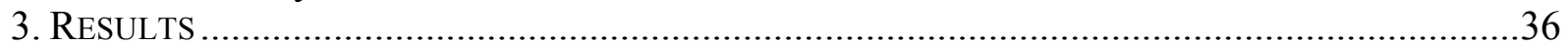

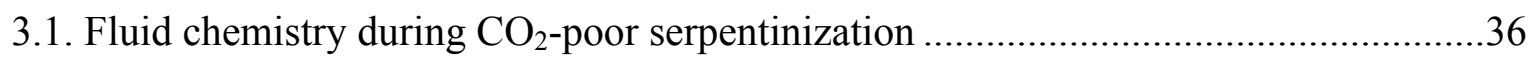

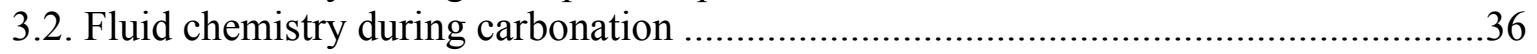

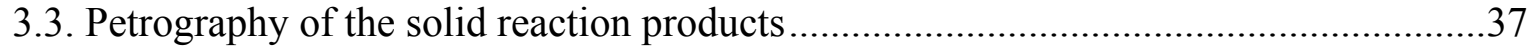

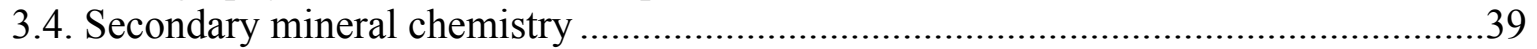

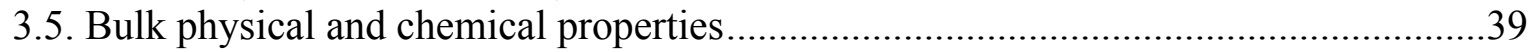

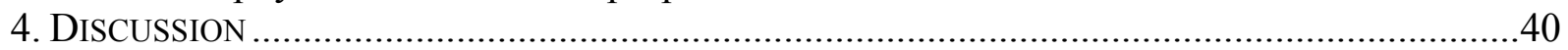

4.1. Reaction pathways during serpentinization of harzburgite in a $\mathrm{CO}_{2}$-poor system......40

4.2. Reaction pathways during mineral carbonation in $\mathrm{C}_{2}$-rich system.....................43

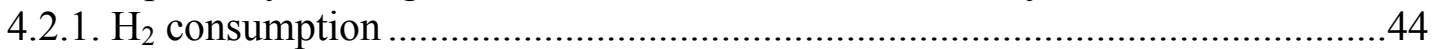

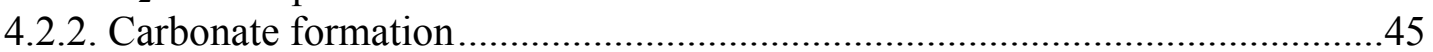

4.3. Mineral carbonation in subseafloor environments ................................................48

4.4. Modeling peridotite-seawater- $\mathrm{CO}_{2}$ interactions ...............................................49

4.5. Implications for carbonate formation in active and fossil oceanic serpentinization

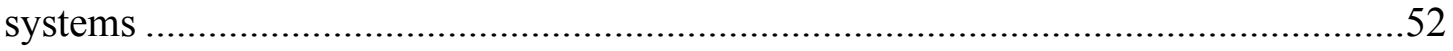

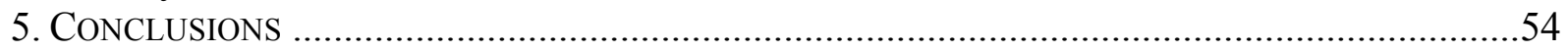

Chapter 3. Linking $\mathrm{CO}_{2}$ reduction and carbonate formation during peridotite-seawater$\begin{array}{lr}\mathrm{CO}_{2} \text { interactions } & 81\end{array}$

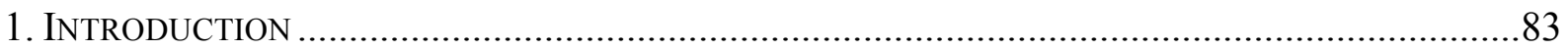

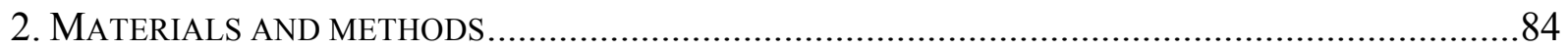

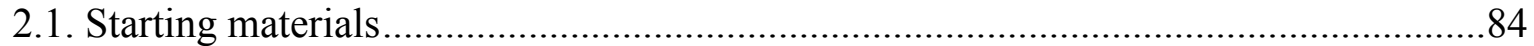

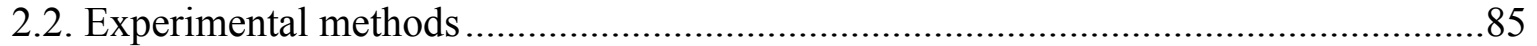

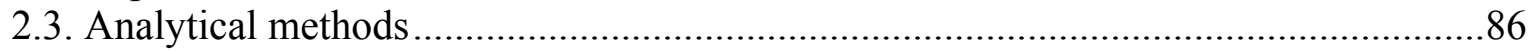




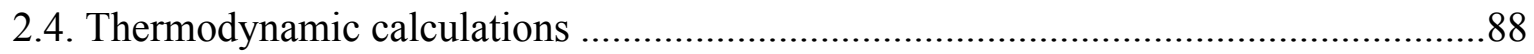

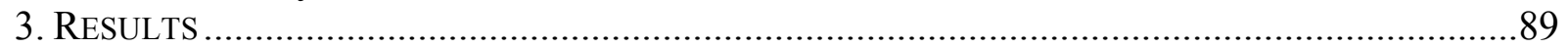

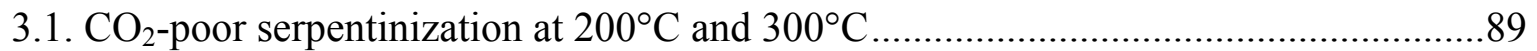

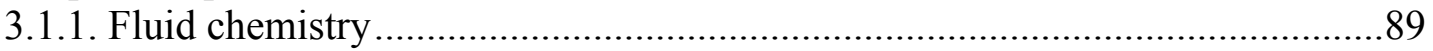

3.1.2. Petrography of serpentinization products......................................................90

3.1.3. Secondary mineral chemistry ......................................................................92

3.1.4. Bulk physical and chemical properties........................................................93

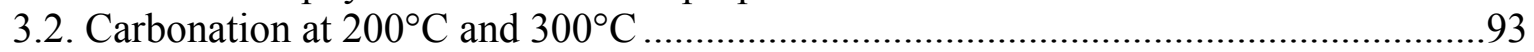

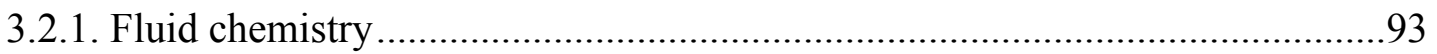

3.2.2. Petrography of carbonate-altered solids .........................................................95

3.2.3. Secondary mineral chemistry .....................................................................97

3.2.4. Bulk physical and chemical properties.......................................................98

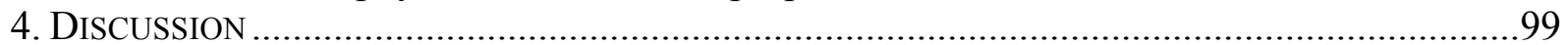

4.1. Reaction pathways during $\mathrm{CO}_{2}$-poor serpentinization ............................................99

4.1.1. $\mathrm{H}_{2}$ generation and Fe partitioning …………….......................................101

4.2. Reaction pathways during peridotite- $\mathrm{CO}_{2}$ interactions .........................................102

4.2.1. Formation of carbonate minerals...............................................................104

4.2.2. Formation of reduced carbon species ..........................................................107

4.3. Implications for carbon reactions in ultramafic-influenced seafloor hydrothermal

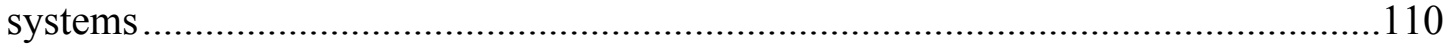

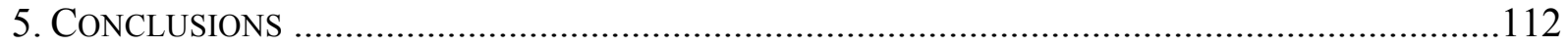

Chapter 4. Isotopic analyses of methane- and ethane-bearing fluid inclusions in olivine-rich rocks: Implications for the origin of abiotic hydrocarbons in ultramaficinfluenced hydrothermal systems

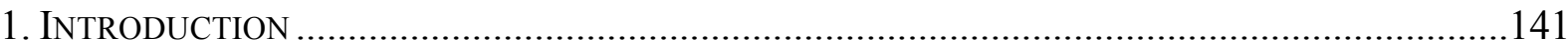

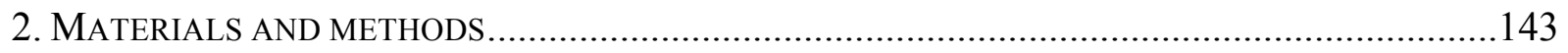

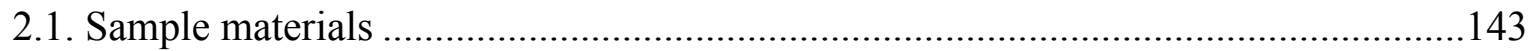

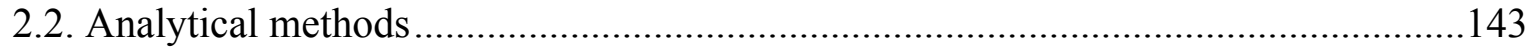

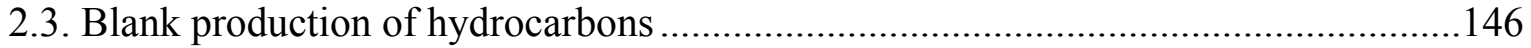

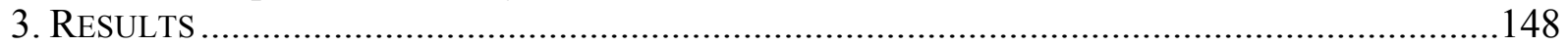

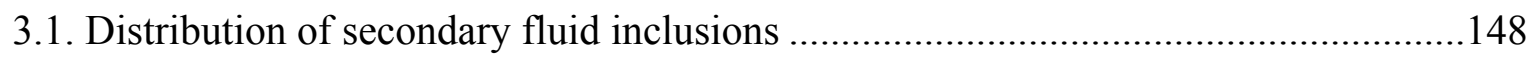

3.2. Composition of secondary fluid inclusions .........................................................148

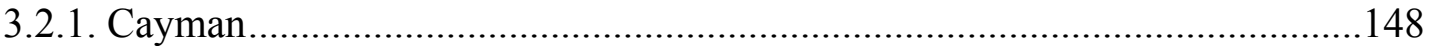

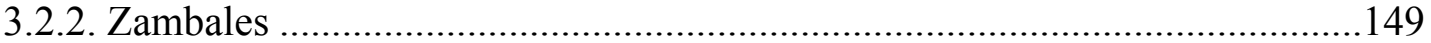

3.3. Hydrocarbon abundances and isotopes ..............................................................150

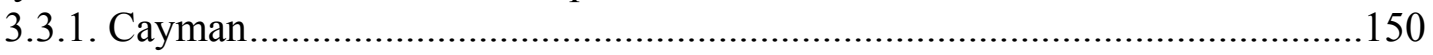

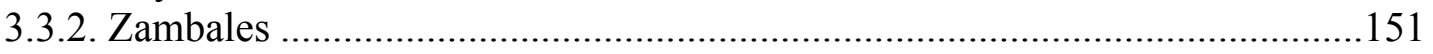

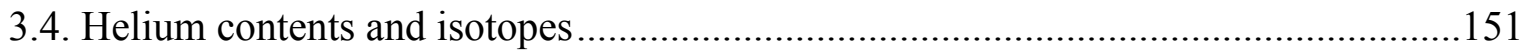

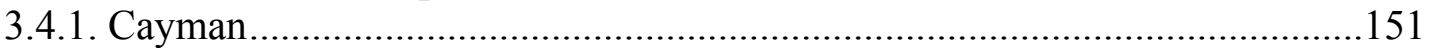

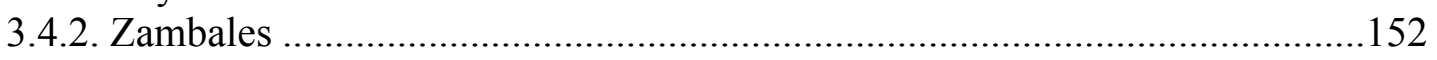

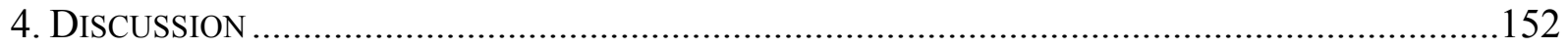

4.1. Formation and compositional evolution of carbon-rich fluid inclusions in oceanic

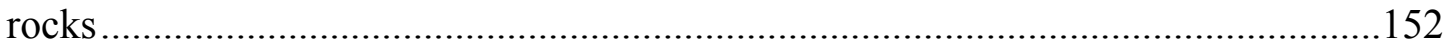

4.1.1. Source of volatiles in secondary fluid inclusions ............................................152 
4.1.2. Compositional evolution of olivine-hosted secondary inclusions

4.1.3. Compositional evolution of plagioclase- and clinopyroxene-hosted secondary inclusions

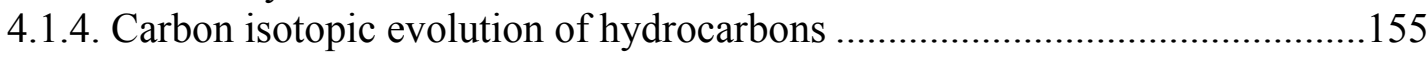

4.2. Comparison of results to previous fluid inclusion studies ......................................156

4.3. Comparison of results to Von Damm hydrothermal fluids ..................................158

4.4. Comparison of results to Zambales gas seeps ......................................................160

4.5. Implications for the origin of abiotic hydrocarbons in serpentinization systems.......161

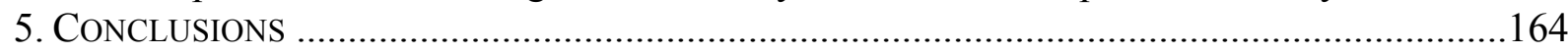

Chapter 5. Conclusions and future research directions 


\section{List of Tables}

\section{Chapter 2.}

2.1 Composition of fluids measured during the experiment........................................56

2.2 Summary of petrographic observations. ...........................................................5

2.3 Electron microprobe analyses of primary and secondary minerals. .............................58

2.4 Composition of harzburgite used in the reaction path model...................................59

2.5 Composition of evolved seawater used in the reaction path model..............................59

\section{Chapter 3.}

3.1 Composition of fluids measured in the $200^{\circ} \mathrm{C}$ experiment......................................114

3.2 Composition of fluids measured in the $300^{\circ} \mathrm{C}$ experiment.....................................115

3.3 Electron microprobe analyses of secondary minerals in the $200^{\circ} \mathrm{C}$ experiment. .........116

3.4 Electron microprobe analyses of secondary minerals in the $300^{\circ} \mathrm{C}$ experiment. .........117

3.5 Bulk element compositions of the starting material and alterations products.............118

\section{Chapter 4.}

4.1 Hydrocarbon abundances from blank measurements. ..........................................166

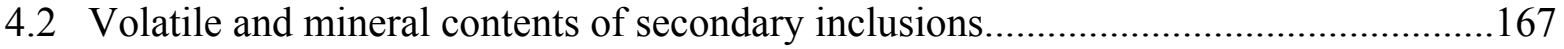

4.3 Whole-rock hydrocarbon abundances and isotopic compositions............................168

4.4 Whole-rock helium contents and isotopic compositions.......................................169

4.5 Calculated water-rock mass ratios for Cayman samples. .......................................170 


\section{List of Figures}

\section{Chapter 1.}

1.1 Schematic diagram showing sources and sinks of dissolved $\mathrm{CO}_{2}$ in submarine hydrothermal systems.

\section{Chapter 2.}

2.1 Changes in measured fluid chemistry during serpentinization of harzburgite at $300^{\circ} \mathrm{C}$ and $35 \mathrm{MPa}$

2.2 Backscattered electron (BSE) images of the solid reaction products.

2.3 Representative Raman spectra of hydrous silicates and magnetite formed in the experiment.

2.4 BSE images of primary and secondary minerals after 20499 hours of reaction.

2.5 BSE images of zoned carbonates containing distinct, rhombohedral layers. Falsecolored Raman maps showing changes in the frequency of the carbonate v1 internal mode.

2.6 Raman spectra of dolomite, Ca-dolomite, and Mg-calcite, showing changes in band frequencies with composition.

2.7 Plot of $\mathrm{Al}_{2} \mathrm{O}_{3}$ content (wt. \%) vs. $\mathrm{Mg} \#$, and plot of $\mathrm{NiO}$ vs. $\mathrm{Cr}_{2} \mathrm{O}_{3}$ content (wt. \%) of minerals replacing olivine, orthopyroxene, and clinopyroxene.

2.8 Results from simultaneous thermogravimetric (TG) analysis and differential thermal analysis (DTA) of the solid products.

2.9 Activity-activity diagrams depicting phase relations in the $\mathrm{MgO}-\mathrm{CaO}-\mathrm{SiO}_{2}-\mathrm{H}_{2} \mathrm{O}-$ $\mathrm{CO}_{2}$ system at $300^{\circ} \mathrm{C}$ and $35 \mathrm{MPa}$

2.10 BSE images of carbonate-altered serpentinites from the Atlantis Massif, $30^{\circ} \mathrm{N}$ Mid-Atlantic Ridge (IODP Expedition 304).

2.11 Reaction path model simulating the serpentinization and subsequent carbonation of harzburgite at $300^{\circ} \mathrm{C}$ and $50 \mathrm{MPa}$.

\section{Chapter 3.}

3.1 Schematic diagram of gas chromatography (GC) system for measuring methanol in seawater solutions.

3.2 Variations in fluid chemistry during serpentinization and subsequent carbonation of harzburgite at $200^{\circ} \mathrm{C}$ and $300^{\circ} \mathrm{C}, 35 \mathrm{MPa}$.

3.3 Backscattered electron (BSE) images of primary and secondary minerals following $\mathrm{CO}_{2}$-poor serpentinization of harzburgite at $200^{\circ} \mathrm{C}$ and $300^{\circ} \mathrm{C}$.

3.4 Measured concentrations of $\Sigma$ formate and methanol at $200^{\circ} \mathrm{C}$ and $300^{\circ} \mathrm{C}$.

3.5 BSE images of the alteration solids following carbonation of serpentinized harzburgite at $200^{\circ} \mathrm{C}$ and $300^{\circ} \mathrm{C}$.

3.6 Raman spectra of magnesite formed during carbonation of harzburgite at $200^{\circ} \mathrm{C} \ldots \ldots .128$

3.7 Raman spectra of carbonate minerals formed during carbonation of harzburgite at $300^{\circ} \mathrm{C}$. 
3.8 Activity-activity diagrams depicting phase equilibria in the $\mathrm{MgO}-\mathrm{CaO}-\mathrm{SiO}_{2}-\mathrm{H}_{2} \mathrm{O}-$ $\mathrm{CO}_{2}$ system at $200^{\circ} \mathrm{C}$ and $300^{\circ} \mathrm{C}, 35 \mathrm{MPa}$.

3.9 Calculated equilibrium concentrations of aqueous species as a function of $\mathrm{pH}$ at $200^{\circ} \mathrm{C}$ and $300^{\circ} \mathrm{C}, 35 \mathrm{MPa}$.

\section{Chapter 4.}

4.1 Bathymetric map of the Mount Dent oceanic core complex on the Mid-Cayman Rise showing sampling locations.

4.2 Map of the Zambales Ophiolite Complex in the Philippines displaying sampling locations.

4.3 Schematic diagram of the stainless steel crushing device in line with a gas chromatography-isotope ratio mass spectroscopy (GC-IRMS) system.

4.4 Plots showing changes in $\delta^{13} \mathrm{C}_{\mathrm{C}_{2} \mathrm{H}_{6}}$ values with analysis of successive aliquots of sample material.

4.5 Thin section photomicrographs of $\mathrm{CH}_{4}$-rich secondary inclusions

4.6 Representative Raman spectra of olivine-hosted secondary inclusions in samples from the Mid-Cayman Rise.

4.7 False-color Raman maps showing the locations of mineral and gaseous species in secondary fluid inclusions.

4.8 Representative Raman spectra of plagioclase-hosted secondary inclusions in samples from the Mid-Cayman Rise.

4.9 Representative Raman spectrum of a clinopyroxene-hosted secondary inclusion. .......182

4.10 Plots of ${ }^{3} \mathrm{He} /{ }^{4} \mathrm{He}\left(\mathrm{R} / \mathrm{R}_{\mathrm{a}}\right)$ vs. ${ }^{4} \mathrm{He}(\mathrm{cc} \mathrm{STP} / \mathrm{g})$ and ${ }^{3} \mathrm{He} /{ }^{4} \mathrm{He}\left(\mathrm{R} / \mathrm{R}_{\mathrm{a}}\right)$ vs. $\mathrm{CH}_{4} /{ }^{3} \mathrm{He}$ for whole rock samples from the Mid-Cayman Rise.

4.11 Range in carbon isotopic compositions for $\mathrm{CH}_{4}$ from whole rock samples in this study, Zambales gas seeps, MOR vent fluids, and SWIR gabbros.

4.12 Range in carbon isotopic compositions for $\mathrm{C}_{2} \mathrm{H}_{6}$ from whole rock samples in this study and ultramafic-influenced MOR vent fluids.

4.13 Range in $\mathrm{CH}_{4} / \mathrm{C}_{2} \mathrm{H}_{6}$ ratios for whole rock samples in this study, Zambales gas seeps, and ultramafic-influenced MOR vent fluids. 


\section{Chapter 1}

\section{Introduction}

\section{Background and motivation}

Hot spring fluids venting from the seafloor are generated by the interaction of seawater with oceanic lithosphere in regions of high heat flow. Hydrothermal venting is especially prominent along mid-ocean ridges and other seafloor spreading centers where upwelling magma or cooling of newly formed crust provides a heat source to drive the convection of seawater within the lithosphere. As seawater penetrates into and flows through hot, permeable rock, a variety of chemical reactions take place that alter the composition of both the circulating seawater and surrounding rock. Hydrothermal fluids issuing from the seafloor at ocean ridges and ridge flanks are the surface expression of this deep-seated chemical, isotopic, and thermal exchange.

Hydrothermal circulation along mid-ocean ridges provides a mechanism for transferring heat and mass between the lithosphere and overlying oceans. Approximately a third of the heat lost from the oceanic lithosphere occurs by convective circulation of seawater in the upper oceanic crust (Sclater et al., 1981; Stein and Stein, 1994). Interactions between seawater and basement rocks also have a profound effect on ocean chemistry and the composition of the oceanic lithosphere through the addition or removal of elements (Alt, 1995). These interactions

depend greatly on the nature of the crustal material, fluid to rock mass ratio, and temperature and pressure conditions of reaction (e.g., Seyfried and Mottl, 1982; Janecky and Seyfried, 1986; McCollom and Bach, 2009). Convection of seawater through basaltic rocks typically generates hot, acidic, and reducing fluids that are enriched in metals and sulfide, and depleted in $\mathrm{Mg}$ and $\mathrm{SO}_{4}$ relative to the initial seawater composition (German and Von Damm, 2006). Relative to reaction with basalt, reaction of seawater with mantle peridotite produces more reduced fluids with higher dissolved $\mathrm{H}_{2}$ concentrations as a result of serpentinization reactions (Charlou et al., 2010). When hot, reduced fluids mix with cold, oxidized seawater in the shallow subsurface or at the seafloor, minerals precipitate and form vent structures (Rona, 1984). Chemical disequilibria 
created by the resulting redox gradients provide a source of metabolic energy for microorganisms in hydrothermal vent environments (Shock et al., 1995; McCollom and Shock, 1997).

Submarine hydrothermal systems are important sites for the production and transformation of carbon compounds. Seafloor vent fluids contain significant quantities of dissolved $\mathrm{CO}_{2}, \mathrm{CH}_{4}$, and other reduced carbon species that have a profound impact on geochemical budgets and biological activity at ocean ridges and ridge flanks (e.g., Merlivat et al., 1987; Charlou et al., 1996; Charlou et al., 2002; Lilley et al., 2003; Proskurowski et al., 2008; McDermott et al., 2015). Reduced carbon species represent a source of carbon and metabolic energy for microbes in vent ecosystems (McCollom and Shock, 1997). Abiotic formation of organic compounds in submarine hydrothermal systems may have supplied prebiotic molecules needed for the emergence of life on Earth (Sleep et al., 2011). Finally, carbon compounds provide important clues to the physical and geochemical conditions present in hydrothermal reaction zones (Bonatti et al., 1974; Cruse and Seewald, 2006). Despite growing evidence for subsurface processes that may generate these dissolved carbon species, fundamental questions remain regarding the sources and sinks of carbon compounds in submarine hydrothermal systems.

Mid-ocean ridge systems release $\mathrm{CO}_{2}$ during decompression and crystallization of basaltic magma, supplying $\sim 1-3 \times 10^{12}$ moles of carbon to the oceans per year (Marty and Tolstikhin, 1998; Cartigny et al., 2008; Fischer, 2008). $\mathrm{CO}_{2}$ may also be supplied by dissolution of carbonates or leaching of carbon-bearing inclusions in plutonic rocks (Alt and Teagle, 1999; Kelley and Früh-Green, 2000). As $\mathrm{CO}_{2}$ migrates through the oceanic crust, it becomes entrained in convecting hydrothermal fluids that subsequently react with the host rock. At slow- and ultraslow-spreading ocean ridges, $\mathrm{CO}_{2}$-bearing fluids may react with mantle peridotite that has been tectonically exhumed to shallow crustal levels. Where peridotite interacts with $\mathrm{CO}_{2}$-bearing hydrous fluids, dissolved inorganic carbon $\left(\Sigma \mathrm{CO}_{2}=\mathrm{CO}_{2}+\mathrm{HCO}_{3}{ }^{-}+\mathrm{CO}_{3}{ }^{2-}\right)$ can be reduced by $\mathrm{H}_{2}$ to form reduced carbon species, utilized by microorganims for biomass synthesis, precipitated as carbonate minerals, or trapped in mineral-hosted fluid inclusions (Figure 1.1). Removal of magmatic $\mathrm{CO}_{2}$ by one or more of these processes prior to hydrothermal venting is suggested by low $\mathrm{CO}_{2} /{ }^{3} \mathrm{He}$ ratios in fluids from the Lost City hydrothermal field (Proskurowski et al., 2008). 
Estimates of the carbon content of basaltic crust suggest that it is either a net carbon sink or is carbon neutral, depending on the magmatic $\mathrm{CO}_{2}$ flux considered (Alt and Teagle, 1999). While exhumed lower crustal and peridotite rocks are thought to take up an order of magnitude less carbon than basaltic crust (Kelemen et al., 2011), their carbon contents have been quantified to a depth of only 200 mbsf (Casey, 1997). Seismic data suggest that serpentinization - or hydration of peridotite - may extend to depths of 1.5-6 km below detachment faults (Kelemen et al., 2004; Canales et al., 2008) and potentially as deep as $15 \mathrm{~km}$ below the seafloor (Schlindwein and Schmid, 2016). Ultramafic lithologies are estimated to comprise $\sim 5-9 \%$ of the rocks exposed along slow- and ultraslow-spreading ocean ridges, which make up about half of the global ridge system (Carlson, 2001; Cannat et al., 2010). In addition, approximately half of all hightemperature hydrothermal systems on slow-spreading ridges are hosted in tectonically-controlled settings, where uplifted olivine-rich plutonic and mantle rocks may interact with circulating fluids in the shallow subsurface (German et al., 2016). This suggests that chemical exchange between seawater and ultramafic lithologies may be more widespread than previously thought and have a significant impact on carbon budgets in the oceanic lithosphere.

The fate of carbon in submarine hydrothermal systems ultimately depends on physical and chemical conditions present in subsurface reaction zones. However, these conditions remain poorly understood due to the technical limitations of sampling fluids and rocks in hydrothermal reaction zones. Serpentinization likely plays a key role in influencing carbon pathways at slowspreading mid-ocean ridges and shallow subduction zone forearcs. Reactions between seawaterderived fluids and ultramafic rocks generate $\mathrm{H}_{2(a q)}$-rich fluids that can drive the reduction of $\Sigma \mathrm{CO}_{2}$ to reduced carbon species (McCollom and Seewald, 2007). Fluids emanating from ultramafic-influenced hydrothermal systems typically contain elevated concentrations of dissolved $\mathrm{H}_{2}, \mathrm{CH}_{4}, \mathrm{C}_{2+}$ hydrocarbons and formate, relative to fluids from basalt-hosted systems (Charlou et al., 2002; Lang et al., 2006; Proskurowski et al., 2008; Lang et al., 2010; McDermott et al., 2015). Evidence from isotopic compositions and relative abundances support an abiotic origin for these reduced carbon compounds (Proskurowski et al., 2008; Charlou et al., 2010; Lang et al., 2010; McDermott et al., 2015). One possible mechanism to account for the abiotic reduction of $\Sigma \mathrm{CO}_{2}$ to $\mathrm{CH}_{4}$ and longer-chain alkanes is Fischer-Tropsch-type synthesis, a process involving the reduction of $\mathrm{CO}_{2}$ by $\mathrm{H}_{2}$ according to the generalized reaction (McCollom and Seewald, 2007): 
$\mathrm{CO}_{2(a q)}+\left(2+\frac{\mathrm{m}}{2 \mathrm{n}}\right) \mathrm{H}_{2(a q)}=\left(\frac{1}{\mathrm{n}}\right) \mathrm{C}_{\mathrm{n}} \mathrm{H}_{\mathrm{m}(a q)}+2 \mathrm{H}_{2} \mathrm{O}$

Additional $\mathrm{CH}_{4}$ and other low-molecular weight organics may be leached from fluid inclusions hosted in plutonic rocks (Kelley and Früh-Green, 1999; McDermott et al., 2015).

Ultramafic-influenced hydrothermal systems also favor the formation of carbonate minerals by generating highly alkaline fluids during low-temperature serpentinization reactions. The most spectacular example of carbonate formation can be seen at the Lost City hydrothermal field, where mixing of Ca-rich, alkaline fluids with seawater results in the precipitation of large carbonate chimneys composed of aragonite, calcite and brucite (Ludwig et al., 2006). Carbonate minerals additionally occur as veins and breccia cements in hydrothermally-altered plutonic and mantle rocks. They predominantly form by precipitation from low temperature $\left(<150^{\circ} \mathrm{C}\right)$ pore fluids during shallow circulation of seawater in the upper crust, or during subsurface mixing of seawater and hydrothermal fluids (Alt and Shanks, 2003; Bach et al., 2011; Schwarzenbach et al., 2013). Recent experimental evidence suggests that carbonates may also form at higher temperatures via fluid-rock interactions in hydrothermal reaction zones (e.g., Andreani et al., 2009; Hövelmann et al., 2011; Van Noort et al., 2013). Mg-, Fe-, and Ca-bearing silicates in peridotite can undergo replacement by carbonate minerals when exposed to $\mathrm{CO}_{2}$-bearing hydrous fluids. This replacement process, known as mineral carbonation, has been documented in several peridotite outcrops on the seafloor (Alt and Shanks, 1998; Kelemen et al., 2004; Müntener and Manatschal, 2006; Andreani et al., 2009).

Despite recent investigations of $\mathrm{CO}_{2}$ reduction and carbonate formation in submarine hydrothermal systems, the physical conditions and mechanisms regulating carbon transformations in ultramafic-influenced systems remain incompletely understood. Models reveal thermodynamic drives for both $\mathrm{CH}_{4}$ and carbonate formation during alteration of peridotite by $\mathrm{CO}_{2}$-rich aqueous fluids (Shock and Canovas, 2010; Klein and Garrido, 2011). However, kinetic barriers present in natural systems necessitate the use of field and laboratory observations to probe the mechanisms and extent of these reactions in subsurface reaction zones. 


\section{Summary of thesis}

This thesis examines the abiotic processes controlling the speciation and distribution of carbon compounds in ultramafic-influenced seafloor hydrothermal systems. The research presented here combines laboratory experiments, thermodynamic models, and analyses of natural samples to further our understanding of the fate of carbon in the oceanic lithosphere.

CHAPTERS 2 and 3 aim to assess the relative extents of carbonate formation and $\mathrm{CO}_{2}$ reduction during interaction of mantle peridotite and $\mathrm{CO}_{2}$-bearing aqueous fluids. These two carbon pathways compete for $\mathrm{CO}_{2}$ under the reducing conditions generated in active serpentinization systems. Laboratory experiments were performed to address the following questions:

1. How much $\mathrm{CO}_{2(a q)}$ undergoes reduction to reduced carbon species, including formate, methanol, and $\mathrm{CH}_{4(\mathrm{aq})}$, providing a potential source of carbon and energy for microorganisms in vent ecosystems?

2. How much $\mathrm{CO}_{2(a q)}$ precipitates as carbonate minerals, and thus becomes sequestered in the subsurface?

3. How do protolith and temperature affect carbon reaction pathways and carbon distributions in seafloor serpentinization systems?

CHAPTER 2 describes a laboratory experiment conducted at $300^{\circ} \mathrm{C}$ to investigate carbonate formation pathways in active serpentinization systems. Results of this chapter suggest that the formation of $\mathrm{Ca}-\mathrm{Mg}$ carbonates is favorable even under strongly reducing conditions, and likely represents a significant carbon sink in ultramafic-influenced hydrothermal systems. Despite the strong thermodynamic drive for abiotic synthesis of $\mathrm{CH}_{4(a q)}$, little if any $\mathrm{CO}_{2(a q)}$ was reduced to $\mathrm{CH}_{4(a q)}$, consistent with slow rates of $\mathrm{CO}_{2(a q)}$ reduction to $\mathrm{CH}_{4(a q)}$ previously documented under hydrothermal conditions.

CHAPTER 3 builds on the results of CHAPTER 2 by examining the synthesis of dissolved carbon intermediaries, including formate and methanol, during alteration of peridotite by $\mathrm{CO}_{2}-$ rich aqueous fluids. In addition, it examines carbon and silicate reactions at lower temperatures, down to $200^{\circ} \mathrm{C}$, making them applicable to a wider range of subseafloor conditions. Results from this chapter reveal that carbonate formation is the dominant sink for dissolved inorganic carbon at temperature and redox conditions typical for submarine serpentinization systems. Although measureable quantities of formate were produced by reduction of $\mathrm{CO}_{2(\mathrm{aq})}$, they account for only a 
minor carbon sink. Despite the strongly reducing conditions generated during serpentinization, strong kinetic barriers to both methanol and $\mathrm{CH}_{4}$ formation were observed at $200-300^{\circ} \mathrm{C}$.

CHAPTERS 2 and 3 confirm previous laboratory studies which have documented sluggish rates of $\mathrm{CO}_{2(a q)}$ reduction to $\mathrm{CH}_{4(a q)}$ on the time scales of active fluid convection in the subseafloor (e.g., McCollom and Seewald, 2001; McCollom and Seewald, 2003; Seewald et al., 2006; McCollom, 2016). These results appear inconsistent with the formation of abiotic $\mathrm{CH}_{4(a q)}$ from dissolved inorganic carbon in actively circulating seawater-derived fluids in the lithosphere (e.g., Charlou et al., 2002; Proskurowski et al., 2008; Charlou et al., 2010). Alternatively, $\mathrm{CH}_{4}$ and potentially longer chain hydrocarbons may be derived from leaching of carbon-rich fluid inclusions in plutonic and mantle rocks in the subsurface (Kelley, 1996; Kelley and Früh-Green, 1999; McCollom and Seewald, 2007; McDermott et al., 2015). This model postulates that magmatic $\mathrm{CO}_{2}$ and $\mathrm{H}_{2} \mathrm{O}$ initially trapped within mineral-hosted inclusions underwent respeciation to $\mathrm{CH}_{4}$ and $\mathrm{C}_{2+}$ hydrocarbons upon cooling to $<400^{\circ} \mathrm{C}$ on geologic time scales (Kelley and Früh-Green, 1999).

CHAPTER 4 aims to better understand the origin of abiotic hydrocarbons in ultramaficinfluenced hydrothermal systems. It tests the hypothesis that abiotic hydrocarbons in ultramaficinfluenced vent fluids are derived from the leaching of fluid inclusions in lower crustal plutonic and mantle rocks. This study analyzed relative abundances and stable isotope compositions of hydrocarbons hosted in fluid inclusions in olivine-rich basement rocks from two active serpentinization systems - the Von Damm hydrothermal field on the Mid-Cayman Rise, and the Zambales ophiolite complex in the Philippines. Comparison of hydrocarbon isotopic signatures in inclusions and associated vent fluids suggests that leaching of fluid inclusions may provide a significant contribution of hydrocarbons to circulating fluids in both submarine and continental serpentinization systems. 


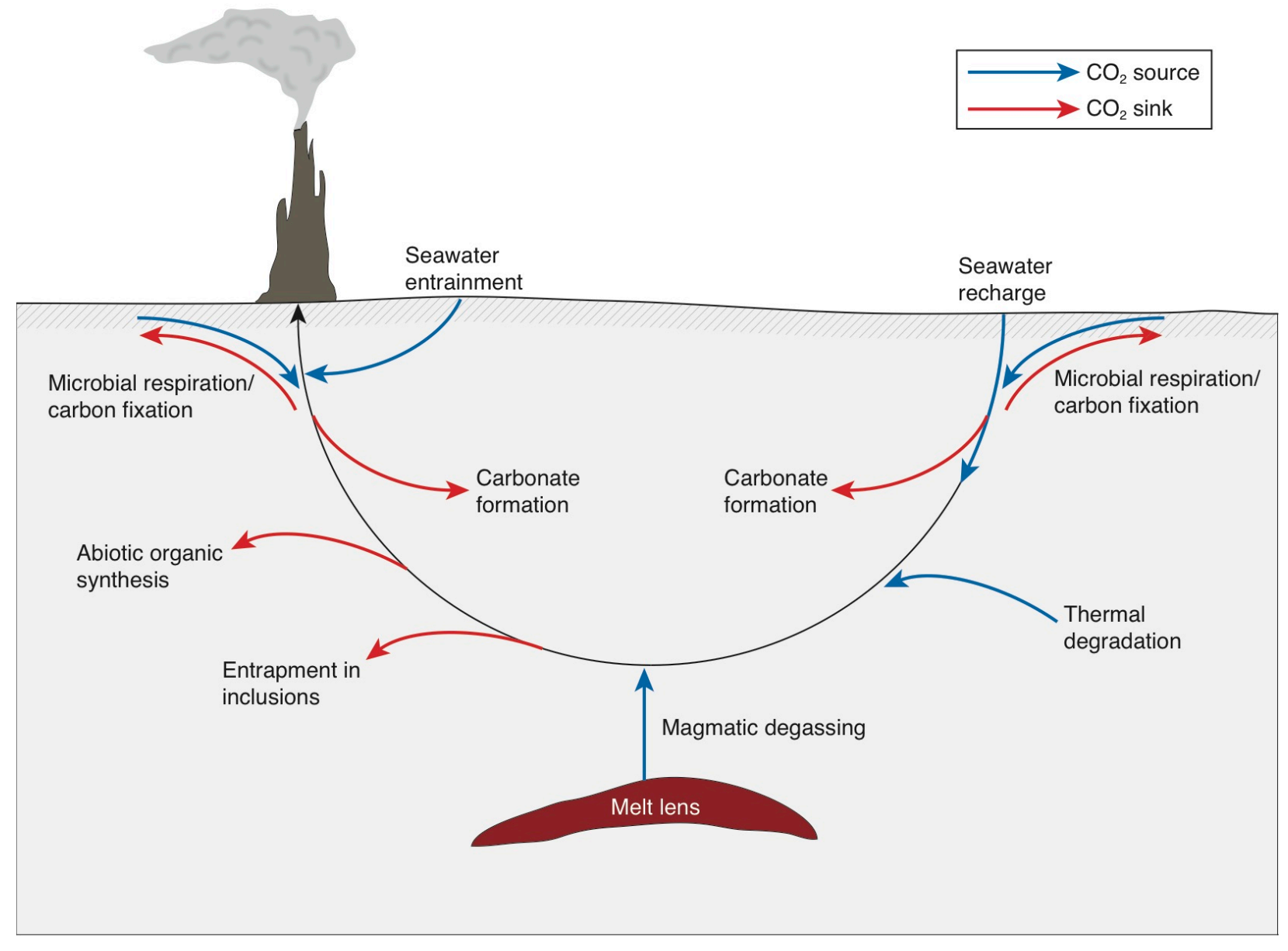

Figure 1.1

Schematic diagram showing sources and sinks of dissolved $\mathrm{CO}_{2}$ in submarine hydrothermal systems. 


\section{REFERENCES}

Alt J. C. (1995) Subseafloor processes in mid-ocean ridge hydrothermal systems. In Seafloor Hydrothermal Systems: Physical, Chemical, Biological, and Geological Interactions (eds. S. E. Humphris, R. A. Zierenberg, L. S. Mullineaux, and R. E. Thomson). American Geophysical Union, Washington, D. C. pp. 85-114.

Alt J. C. and Shanks W. C. (1998) Sulfur in serpentinized oceanic peridotites: Serpentinization processes and microbial sulfate reduction. J. Geophys. Res. 103, 9917-9929.

Alt J. C. and Shanks W. C. (2003) Serpentinization of abyssal peridotites from the MARK area, Mid-Atlantic Ridge: Sulfur geochemistry and reaction modeling. Geochim. Cosmochim. Acta 67, 641-653.

Alt J. C. and Teagle D. A. H. (1999) The uptake of carbon during alteration of ocean crust. Geochim. Cosmochim. Acta 63, 1527-1535.

Andreani M., Luquot L., Gouze P., Godard M., Hoisé E. and Gibert B. (2009) Experimental study of carbon sequestration reactions controlled by the percolation of $\mathrm{CO}_{2}$-rich brine through peridotites. Environ. Sci. Technol. 43, 1226-1231.

Bach W., Rosner M., Jöns N., Rausch S., Robinson L. F., Paulick H. and Erzinger J. (2011) Carbonate veins trace seawater circulation during exhumation and uplift of mantle rock: Results from ODP Leg 209. Earth Planet. Sci. Lett. 311, 242-252.

Bonatti E., Emiliani C., Ferrara G., Honnorez J. and Rydell H. (1974) Ultramafic-carbonate breccias from the equatorial Mid Atlantic Ridge. Mar. Geol. 16, 83-102.

Canales J. P., Tucholke B. E., Xu M., Collins J. A. and DuBois D. L. (2008) Seismic evidence for large-scale compositional heterogeneity of oceanic core complexes. Geochemistry, Geophys. Geosystems 9, Q08002, doi:10.1029/2008GC002009.

Cannat M., Fontaine F. and Escartín J. (2010) Serpentinization and associated hydrogen and methane fluxes at slow spreading ridges. In Diversity of Hydrothermal Systems on Slow Spreading Ocean Ridges (eds. P. A. Rona, C. W. Devey, J. D. And, and B. J. Murton). American Geophysical Union, Washington, D. C. pp. 241-264.

Carlson R. L. (2001) The abundance of ultramafic rocks in Atlantic Ocean crust. Geophys. J. Int. 144, 37-48.

Cartigny P., Pineau F., Aubaud C. and Javoy M. (2008) Towards a consistent mantle carbon flux estimate: Insights from volatile systematics $\left(\mathrm{H}_{2} \mathrm{O} / \mathrm{Ce}, \delta \mathrm{D}, \mathrm{CO}_{2} / \mathrm{Nb}\right)$ in the North Atlantic mantle $\left(14^{\circ} \mathrm{N}\right.$ and $\left.34^{\circ} \mathrm{N}\right)$. Earth Planet. Sci. Lett. 265, 672-685.

Casey J. (1997) Comparison of major- and trace element geochemistry of abyssal peridotites and mafic plutonic rocks with basalts from the MARK region of the Mid-Atlantic Ridge. Proc. Ocean Drill. Program, Sci. Results 153, 181-241.

Charlou J. L., Fouquet Y., Donval J. P., Auzende J. M., Jean-Baptiste P., Stievenard M. and Michel S. (1996) Mineral and gas chemistry of hydrothermal fluids on an ultrafast spreading ridge: East Pacific Rise, $17^{\circ}$ to $19^{\circ} \mathrm{S}$ (Naudur cruise, 1993) phase separation processes controlled by volcanic and tectonic activity. J. Geophys. Res. 101, 15,899-15,919.

Charlou J. L., Donval J. P., Fouquet Y., Jean-Baptiste P. and Holm N. (2002) Geochemistry of high $\mathrm{H}_{2}$ and $\mathrm{CH}_{4}$ vent fluids issuing from ultramafic rocks at the Rainbow hydrothermal field (36 14 'N, MAR). Chem. Geol. 191, 345-359.

Charlou J. L., Donval J. P., Konn C., Ondréas H., Fouquet Y., Jean-Baptiste P. and Fourré E. (2010) High production and fluxes of $\mathrm{H}_{2}$ and $\mathrm{CH}_{4}$ and evidence of abiotic hydrocarbon synthesis by serpentinization in ultramafic-hosted hydrothermal systems on the Mid- 
Atlantic Ridge. In Diversity Of Hydrothermal Systems On Slow Spreading Ocean Ridges (eds. P. A. Rona, C. W. Devey, J. Dyment, and B. J. Murton). American Geophysical Union, Washington, D. C. pp. 265-296.

Cruse A. M. and Seewald J. S. (2006) Geochemistry of low-molecular weight hydrocarbons in hydrothermal fluids from Middle Valley, northern Juan de Fuca Ridge. Geochim.

Cosmochim. Acta 70, 2073-2092.

Fischer T. P. (2008) Fluxes of volatiles $\left(\mathrm{H}_{2} \mathrm{O}, \mathrm{CO}_{2}, \mathrm{~N}_{2}, \mathrm{Cl}, \mathrm{F}\right)$ from arc volcanoes. Geochem. $J$. 42, 21-38.

German C. R. and Von Damm K. L. (2006) Hydrothermal processes. In Treatise on

Geochemistry, vol. 6, The Oceans and Marine Geochemistry (ed. H. Elderfield). Elsevier, Oxford, U. K. pp. 181-222.

German C. R., Petersen S. and Hannington M. D. (2016) Hydrothermal exploration of mid-ocean ridges: Where might the largest sulfide deposits be forming? Chem. Geol. 420, 114-126.

Hövelmann J., Austrheim H., Beinlich A. and Munz I. A. (2011) Experimental study of the carbonation of partially serpentinized and weathered peridotites. Geochim. Cosmochim. Acta 75, 6760-6779.

Janecky D. R. and Seyfried W. E. J. (1986) Hydrothermal serpentinization of peridotite within the oceanic crust: Experimental investigations of mineralogy and major element chemistry. Geochim. Cosmochim. Acta 50, 1357-1378.

Kelemen P. B., Kikawa E., Miller D. J., Abe N., Bach W., Carlson R. L., Casey J. F., Chambers L. M., Cheadle M., Cipriani A., Dick H. J. B., Faul U., Garces M., Garrido C., Gee J. S., Godard M. M., Graham D. W., Griffin D. W., Harvey J., Ildefonse B., Iturrino G. J., Josef J., Meurer W. P., Paulick H., Rosner M., Schroeder T., Seyler M. and Takazawa E. (2004) Site 1275. Proc. Ocean Drill. Program, Initial Reports 209, 1-167.

Kelemen P. B., Matter J., Streit E. E., Rudge J. F., Curry W. B. and Blusztajn J. (2011) Rates and mechanisms of mineral carbonation in peridotite: Natural processes and recipes for enhanced, in situ $\mathrm{CO}_{2}$ capture and storage. Annu. Rev. Earth Planet. Sci. 39, 545-576.

Kelley D. S. (1996) Methane-rich fluids in the oceanic crust. J. Geophys. Res. Earth 101, 29432962.

Kelley D. S. and Früh-Green G. L. (1999) Abiogenic methane in deep-seated mid-ocean ridge environments: Insights from stable isotope analyses. J. Geophys. Res. 104, 10,439-10,460.

Kelley D. S. and Früh-Green G. L. (2000) Volatiles in mid-ocean ridge environments. Spec. Pap. Soc. Am., 237-260.

Klein F. and Garrido C. J. (2011) Thermodynamic constraints on mineral carbonation of serpentinized peridotite. Lithos 126, 147-160.

Lang S. Q., Butterfield D. a., Lilley M. D., Paul Johnson H. and Hedges J. I. (2006) Dissolved organic carbon in ridge-axis and ridge-flank hydrothermal systems. Geochim. Cosmochim. Acta 70, 3830-3842.

Lang S. Q., Butterfield D. A., Schulte M., Kelley D. S. and Lilley M. D. (2010) Elevated concentrations of formate, acetate and dissolved organic carbon found at the Lost City hydrothermal field. Geochim. Cosmochim. Acta 74, 941-952.

Lilley M. D., Butterfield D. a, Lupton J. E. and Olson E. J. (2003) Magmatic events can produce rapid changes in hydrothermal vent chemistry. Nature 422, 878-881.

Ludwig K. A., Kelley D. S., Butterfield D. A., Nelson B. K. and Früh-Green G. (2006) Formation and evolution of carbonate chimneys at the Lost City Hydrothermal Field. Geochim. Cosmochim. Acta 70, 3625-3645. 
Marty B. and Tolstikhin I. N. (1998) $\mathrm{CO}_{2}$ fluxes from mid-ocean ridges, arcs and plumes. Chem. Geol. 145, 233-248.

McCollom T. M. (2016) Abiotic methane formation during experimental serpentinization of olivine. Proc. Natl. Acad. Sci. 113, 13,965-13,970.

McCollom T. M. and Bach W. (2009) Thermodynamic constraints on hydrogen generation during serpentinization of ultramafic rocks. Geochim. Cosmochim. Acta 73, 856-875.

McCollom T. M. and Seewald J. S. (2001) A reassessment of the potential for reduction of dissolved $\mathrm{CO}_{2}$ to hydrocarbons during serpentinization of olivine. Geochim. Cosmochim. Acta 65, 3769-3778.

McCollom T. M. and Seewald J. S. (2003) Experimental constraints on the hydrothermal reactivity of organic acids and acid anions: I. Formic acid and formate. Geochim. Cosmochim. Acta 67, 3625-3644.

McCollom T. M. and Seewald J. S. (2007) Abiotic synthesis of organic compounds in deep-sea hydrothermal environments. Chem. Rev. 107, 382-401.

McCollom T. M. and Shock E. L. (1997) Geochemical constraints on chemolithoautotrophic metabolism by microorganisms in seafloor hydrothermal systems. Geochim. Cosmochim. Acta 61, 4375-4391.

McDermott J. M., Seewald J. S., German C. R. and Sylva S. P. (2015) Pathways for abiotic organic synthesis at submarine hydrothermal fields. Proc. Natl. Acad. Sci. 112, 7668-7672.

Merlivat L., Pineau F. and Javoy M. (1987) Hydrothermal vent waters at $13^{\circ} \mathrm{N}$ on the East Pacific Rise: Isotopic compostion and gas concentration. Earth Planet. Sci. Lett. 84, 100108.

Müntener O. and Manatschal G. (2006) High degrees of melt extraction recorded by spinel harzburgite of the Newfoundland margin: The role of inheritance and consequences for the evolution of the southern North Atlantic. Earth Planet. Sci. Lett. 252, 437-452.

Proskurowski G., Lilley M. D., Seewald J. S., Früh-Green G. L., Olson E. J., Lupton J. E., Sylva S. P. and Kelley D. S. (2008) Abiogenic hydrocarbon production at Lost City Hydrothermal Field. Science 319, 604-607.

Rona P. (1984) Hydrothermal mineralization at seafloor spreading centers. Earth Sci. Rev. 20, 1104.

Schlindwein V. and Schmid F. (2016) Mid-ocean-ridge seismicity reveals extreme types of ocean lithosphere. Nature 535, 276-279.

Schwarzenbach E. M., Früh-Green G. L., Bernasconi S. M., Alt J. C. and Plas A. (2013) Serpentinization and carbon sequestration: A study of two ancient peridotite-hosted hydrothermal systems. Chem. Geol. 351, 115-133.

Sclater J. G., Parsons B. and Jaupart C. (1981) Oceans and continents: Similarities and differences in the mechanisms of heat loss. J. Geophys. Res. 86, 11,535-11,552.

Seewald J. S., Zolotov M. Y. and McCollom T. (2006) Experimental investigation of single carbon compounds under hydrothermal conditions. Geochim. Cosmochim. Acta 70, 446460.

Seyfried W. E. J. and Mottl M. J. (1982) Hydrothermal alteration of basalt by seawater under seawater-dominated conditions. Geochim. Cosmochim. Acta 46, 985-1002.

Shock E. and Canovas P. (2010) The potential for abiotic organic synthesis and biosynthesis at seafloor hydrothermal systems. Geofluids 10, 161-192.

Shock E. L., McCollom T. and Schulte M. D. (1995) Geochemical constraints on chemolithoautotrophic reactions in hydrothermal systems. Orig. Life Evol. Biosph. 25, 141- 
159.

Sleep N. H., Bird D. K. and Pope E. C. (2011) Serpentinite and the dawn of life. Philos. Trans. R. Soc. B Biol. Sci. 366, 2857-2869.

Stein C. A. and Stein S. (1994) Constraints on hydrothermal heat flux through the oceanic lithosphere from global heat flow. J. Geophys. Res. 99, 3081-3095.

van Noort R., Spiers C. J., Drury M. R. and Kandianis M. T. (2013) Peridotite dissolution and carbonation rates at fracture surfaces under conditions relevant for in situ mineralization of $\mathrm{CO}_{2}$. Geochim. Cosmochim. Acta 106, 1-24. 


\title{
Chapter 2
}

\section{Experimental study of carbonate formation in oceanic peridotite ${ }^{1}$}

\begin{abstract}
Interactions of $\mathrm{CO}_{2}$-rich aqueous fluids with mantle peridotite have major implications for geochemical budgets and microbial life in the shallow oceanic lithosphere through the formation of carbonate minerals and reduced carbon species. However, the underlying mechanisms controlling the transformation of $\mathrm{CO}_{2}$ to carbonates in ultramafic-hosted hydrothermal systems remain incompletely understood. A long-term laboratory experiment was conducted at $300^{\circ} \mathrm{C}$ and $35 \mathrm{MPa}$ to investigate serpentinization and carbonate formation pathways during hydrothermal alteration of peridotite. Powdered harzburgite was initially reacted with a Ca-rich aqueous fluid for 14592 hours (608 days) and changes in fluid composition were monitored with time. Once the system reached a steady state, a $\mathrm{CO}_{2(a q)}$-rich fluid was injected and allowed to react with the system for 5907 hours (246 days). Fluid speciation and mineral analyses suggest that serpentinization of harzburgite in the $\mathrm{CO}_{2}$-poor system led to the precipitation of serpentine, brucite, magnetite, and minor calcite, in addition to other minor phases including chlorite and sulfur-poor Ni sulfides. The addition of the $\mathrm{CO}_{2(a q)}$-rich fluid caused dolomite, Ca-rich dolomite, and high-Mg calcite to form at the expense of olivine, calcite, and brucite, while serpentine remained unreactive. Replacement textures and mineral assemblages mimic those documented in carbonate-altered seafloor serpentinites, particularly those from the Mid-Atlantic Ridge and the Iberia Margin. In contrast to thermodynamic predictions, magnesite did not form in the experiment because the dissolution of clinopyroxene, in combination with the lack of serpentine reactivity, maintained low $\mathrm{Mg} / \mathrm{Ca}$ ratios in solution. Clinopyroxene dissolution and unreactive serpentine may similarly maintain low $\mathrm{Mg} / \mathrm{Ca}$ ratios in submarine serpentinization systems and limit magnesite formation in subseafloor environments. Results of this study suggest that the formation of $\mathrm{Ca}-\mathrm{Mg}$ carbonates by mineral carbonation is favorable in subseafloor
\end{abstract}

\footnotetext{
${ }^{1}$ Published as: Grozeva N. G., Klein F., Seewald J. S. and Sylva S. P. (2017) Experimental study of carbonate formation in oceanic peridotite. Geochim. Cosmochim. Acta 199, 264-286. Copyright 2017 Elsevier.
} 
serpentinization systems and likely represents a significant, but poorly quantified, carbon sink in hydrothermally altered oceanic lithosphere created at slow-spreading mid-ocean ridges. 


\section{INTRODUCTION}

Mantle peridotite is exposed in a range of tectonic settings, including mid-ocean ridges, continental margins, subduction zone fore-arcs, and ophiolites (Fryer et al., 1995; Bodinier and Godard, 2003; Dick et al., 2003; Cannat et al., 2010). When exposed to aqueous fluids near Earth's surface, peridotite undergoes hydrothermal alteration to form hydrous silicates, carbonates, oxides, and sulfides (e.g., Frost, 1985). The replacement of silicate and hydroxide minerals by carbonates - a process referred to as mineral carbonation - sequesters dissolved $\mathrm{CO}_{2}$ into solids that can be stable over geologic time (e.g., Kelemen and Matter, 2008). Since hydrothermally altered peridotite is thought to comprise 5-9\% of the rocks exposed along slowand ultraslow-spreading mid-ocean ridges (Carlson, 2001; Cannat et al., 2010), mineral carbonation represents a potentially significant sink for carbon in the shallow oceanic lithosphere.

Mineral carbonation has received considerable attention as a means to sequester atmospheric $\mathrm{CO}_{2}$ and mitigate global warming (e.g., Seifritz, 1990; Kelemen et al., 2011). A number of field, experimental, and theoretical studies have examined carbonation reactions in ultramafic substrates (Bruni et al., 2002; Cipolli et al., 2004; Giammar et al., 2005; Hansen et al., 2005; Kelemen and Matter, 2008; Andreani et al., 2009; King et al., 2010; Klein and Garrido, 2011; Hövelmann et al., 2011; Paukert et al., 2012; Van Noort et al., 2013; Klein and McCollom, 2013; Lafay et al., 2014; Peuble et al., 2015a; Peuble et al., 2015b). With only few exceptions, previous experimental studies have focused on the carbonation of olivine to magnesite, which can occur by the simplified reaction

$$
\begin{array}{lr}
\mathrm{Mg}_{2} \mathrm{SiO}_{4}+2 \mathrm{CO}_{2(a q)}= & 2 \mathrm{MgCO}_{3}+\mathrm{SiO}_{2} . \\
\text { olivine } & \text { magnesite quartz }
\end{array}
$$

Magnesite is common in carbonate-altered peridotite (soapstone and listvenite) on land, which is typically associated with convergent plate margins, such as ophiolites in orogenic belts and exhumed mélange rocks in paleo-subduction zones (Naldrett, 1966; Griffis, 1972; Barnes et al., 1973; Dabitzias, 1980; Böhlke, 1989; Schandl and Wicks, 1991; Hansen et al., 2005; Robinson et al., 2005; Spandler et al., 2008; Boschi et al., 2009; Beinlich et al., 2012; Ulrich et al., 2014; Falk and Kelemen, 2015). The carbon in these rocks appears to be dominantly sourced from sedimentary lithologies that were affected by metamorphic decarbonation reactions (Barnes 
et al., 1973; Dabitzias, 1980; Schandl and Wicks, 1991; Beinlich et al., 2012; Falk and Kelemen, 2015). Magnesite also occurs in completely to incompletely serpentinized peridotite that has undergone low temperature alteration by $\mathrm{Mg}$ - and $\mathrm{HCO}_{3}$-rich waters (Barnes and O'Neil, 1969; Stanger, 1985; Bruni et al., 2002; Kelemen and Matter, 2008; Kelemen et al., 2011; Paukert et al., 2012; Oskierski et al., 2013; del Real et al., 2016; Schwarzenbach et al., 2016b). Here, fluids appear to be meteoric in origin, with carbon derived mainly from soil or atmospheric $\mathrm{CO}_{2}$ (Schroll, 2002; Oskierski et al., 2013; Schwarzenbach et al., 2016b).

Whereas magnesite commonly occurs in ultramafic outcrops on land, it is rarely found in association with carbonate-altered mantle rocks in oceanic settings (Gablina et al., 2006). Serpentinized peridotite in the shallow oceanic lithosphere commonly contains Ca-bearing carbonates such as calcite, aragonite, and dolomite instead of magnesite (Bonatti et al., 1974; Ludwig et al., 2006; Eickmann et al., 2009; Kelemen et al., 2011; Bach et al., 2011; Schwarzenbach et al., 2013; Schroeder et al., 2015). Carbonates can form in several ways in the oceanic lithosphere, including homogeneous precipitation from pore fluids, and replacement of silicate and hydroxide minerals via mineral carbonation (Bonatti et al., 1974; Andreani et al., 2009; Eickmann et al., 2009; Bach et al., 2011; Bach et al., 2013; Schroeder et al., 2015). Homogeneous carbonate precipitation in the subsurface can occur during conductive heating of seawater, conductive cooling of hydrothermal fluid, or mixing of seawater with hydrothermal fluid (Bonatti et al., 1974; Eickmann et al., 2009; Bach et al., 2011; Klein et al., 2015b; Schroeder et al., 2015). Mineral carbonation can take place during low temperature, oxidative alteration of peridotite at ridge flanks and passive margins, or at higher temperatures in ridge crest environments. Several studies have documented the replacement of olivine and pyroxene in these environments by Ca-bearing carbonates, including calcite, high-Mg calcite, and dolomite (Alt and Shanks, 1998; Müntener and Manatschal, 2006; Andreani et al., 2009). On the basis of experimental results, Hövelmann et al. (2011) recognized that calcite can readily replace olivine and its weathering products during alteration by $\mathrm{CO}_{2}$-saturated and $\mathrm{Ca}$-rich fluids at $200^{\circ} \mathrm{C}$, whereas magnesite is favored if the reacting fluid is Ca-poor. While dolomite was supersaturated in one Ca-bearing experiment, it did not precipitate, possibly due to kinetic factors impeding the formation of Mg-bearing carbonates relative to Ca-carbonates (Hövelmann et al., 2011). Peuble et al. $(2015 \mathrm{a}, 2015 \mathrm{~b})$ reported the formation of both magnesite and dolomite in a set of reactive percolation experiments involving injection of $\mathrm{CO}_{2}$-rich and $\mathrm{Ca}$-poor fluid into olivine 
aggregates at $190^{\circ} \mathrm{C}$. Formation of carbonate minerals appeared to be controlled by hydrodynamic processes, with dolomite and magnesite precipitating in regions of moderate and high fluid flow, respectively. The authors note that differences in fluid flow impact the local solution chemistry, which in turn affects carbonate precipitation. Jones et al. (2010), who conducted a laboratory serpentinization experiment at $200^{\circ} \mathrm{C}$ using olivine, chromite, and evolved seawater rich in dissolved $\mathrm{Ca}$ and $\mathrm{HCO}_{3}$, reported calcite and siderite as the dominant carbonate minerals, whereas dolomite and magnesite did not reach saturation. To our knowledge, siderite has not been detected in oceanic serpentinite and it remains unclear what role it plays in active serpentinization systems in the subseafloor. Whether magnesite, dolomite, or calcite forms in seafloor serpentinization systems appears to be ultimately controlled by the $\mathrm{Mg} / \mathrm{Ca}$ ratio of the reacting fluid at the mineral scale (cf. Jones et al., 2010; Hövelmann et al., 2011; Klein and McCollom, 2013; Peuble et al., 2015a; Peuble et al., 2015b). However, it remains unclear what role fluid-rock reactions play in controlling the $\mathrm{Mg} / \mathrm{Ca}$ ratio during interactions of $\mathrm{CO}_{2}$-bearing hydrothermal fluids and peridotite in natural systems.

The purpose of this study was to investigate the reaction pathways and modes of carbonate formation during hydrothermal alteration of harzburgite under strongly reducing conditions and in the presence of a Ca-rich fluid, typical of subseafloor serpentinization systems. We conducted a long-term ( 2.5 years) laboratory experiment, performed detailed analyses of fluid composition and mineralogy, and compared our experimental results to thermodynamic models and natural samples. The present study highlights the important roles that protolith and fluid composition play in regulating carbonate formation pathways during interactions of $\mathrm{CO}_{2}$ rich fluids and peridotite.

\section{MATERIALS AND METHODS}

The laboratory experiment described here was conducted in two stages. In the first stage, powdered harzburgite was reacted with an aqueous solution of seawater chlorinity at $300^{\circ} \mathrm{C}$ and $35 \mathrm{MPa}$. This initial step was done to simulate conditions associated with serpentinizing harzburgite in the absence of $\mathrm{CO}_{2}$ in a mid-ocean ridge setting. In the second stage, a $\mathrm{CO}_{2(a q)}$-rich aqueous fluid was injected into the reaction cell to simulate mineral carbonation of serpentinizing peridotite under strongly reducing conditions. Changes in fluid chemistry were 
monitored during the experiment and solid alteration products were examined at the termination of the experiment.

\subsection{Starting materials}

The seawater chlorinity starting solution was enriched in $\mathrm{Ca}$ and devoid of $\mathrm{Mg}$ and $\mathrm{SO}_{4}$, and was intended to represent an evolved fluid in a hydrothermal reaction zone (Table 2.1). The solution was prepared by mixing reagent grade $\mathrm{NaCl}, \mathrm{CaCl}_{2} \cdot \mathrm{H}_{2} \mathrm{O}$, and $\mathrm{KCl}$ with deionized water.

A fresh mantle xenolith from the Meerfelder Maar (Eifel Volcanic Field, Germany) was used as the peridotite protolith to avoid preexisting alteration products that are characteristic of oceanic peridotites. The xenolith can be classified as a spinel harzburgite composed of $\sim 70$ vol. \% olivine, 26 vol. \% orthopyroxene, 4 vol. \% clinopyroxene, 0.9 vol. \% Cr-spinel, and trace ( $<0.1$ vol. \%) amphibole, glass, and primary sulfides including pentlandite and pyrrhotite. Olivine, orthopyroxene, and clinopyroxene have $\mathrm{Mg \# s}(\mathrm{Mg} /(\mathrm{Mg}+\mathrm{Fe}) \times 100)$ of $91.1,91.0$, and 91.4, respectively, and have compositions typical for those minerals in mantle peridotite (Table 2.3). The composition of Cr-spinel was not determined as petrographic analysis of the solid products showed no evidence for alteration of $\mathrm{Cr}$-spinel during the experiment. Pentlandite has an empirical composition of $\mathrm{Ni}_{4.9} \mathrm{Fe}_{4.1} \mathrm{~S}_{8}$, and is enriched in $\mathrm{Ni}$ relative to its stoichiometric formula. Pyrrhotite has an approximately stoichiometric composition as determined by energydispersive spectroscopy. A more detailed description of the xenolith's mineralogical and chemical composition is presented in Klein et al. (2015a). The xenolith was cored using a diamond drill to avoid alteration rims, cut into cm-sized pieces, and powdered using a tungstencarbide disk grinder. The powder was wet sieved to collect the 63-125 $\mu \mathrm{m}$ fraction, triply rinsed in deionized water, and dried and stored at $40^{\circ} \mathrm{C}$ until the experiment was conducted.

\subsection{Experimental methods}

The experiment was conducted in a flexible-cell hydrothermal apparatus consisting of a gold bag, titanium closure piece, and titanium exit tube enclosed in a stainless-steel pressure vessel (Seyfried et al., 1987). The pressure vessel was filled with deionized water, which acted as the pressure medium. Minerals and fluids were loaded into the gold bag, pressurized, and then heated to $300^{\circ} \mathrm{C}$. The titanium exit tube allowed fluids to be introduced to or extracted from the gold bag during the course of the experiment. 
During the initial stage of the experiment, $18.19 \mathrm{~g}$ of harzburgite powder was reacted with $41.14 \mathrm{~g}$ of starting solution containing no added $\mathrm{CO}_{2}$ at $300^{\circ} \mathrm{C}$ and $35 \mathrm{MPa}$. On six selected sampling occasions, 3 to $6 \mathrm{~g}$ of fluid was removed from the reaction cell in gas-tight, glass syringes to monitor changes in fluid chemistry over time. At the end of this stage, $16.20 \mathrm{~g}$ of fluid remained in the reaction cell. After 14592 hours of reaction, $23.57 \mathrm{~g}$ of starting solution containing $\sim 670 \mathrm{mmol} / \mathrm{kg}$ of isotopically labeled $\mathrm{CO}_{2(a q)}\left(>99 \%{ }^{13} \mathrm{CO}_{2}\right.$, Cambridge Isotope Laboratories, Inc.) was injected into the reaction cell to simulate mineral carbonation of serpentinizing harzburgite. ${ }^{13} \mathrm{C}$-labeled $\mathrm{CO}_{2}$ was used to trace carbon sources and sinks during the experiment. Fluids were injected using a $150 \mathrm{~mL}$ titanium piston-cylinder. The pistoncylinder was first connected to a pressurized ${ }^{13} \mathrm{CO}_{2(g)}$ tank and filled with gas. Fresh starting solution was then added to the piston-cylinder and the system was pressurized to $6.9 \mathrm{MPa}$ for 1 hour to allow the ${ }^{13} \mathrm{CO}_{2(g)}$ to dissolve in the fluid. The piston-cylinder was then connected to the titanium exit tube and the $\mathrm{CO}_{2(a q)}$-rich fluid was pumped into the gold bag at a rate of $3 \mathrm{~mL} / \mathrm{min}$. Based on the concentration of $\mathrm{CO}_{2(a q)}$ in the injected fluid and the amount of fluid injected, the calculated concentration of $\Sigma \mathrm{CO}_{2}$ in the reaction cell was $399 \mathrm{mmol} / \mathrm{kg}$ immediately following the injection.

Following the injection of the ${ }^{13} \mathrm{CO}_{2}$-enriched solution, the system was allowed to react for 5907 hours, during which fluid samples were removed from the reaction cell on six different occasions for chemical characterization. The experiment was terminated by cooling the reaction vessel to room temperature and depressurizing the vessel. The solid reaction products were removed from the reaction vessel, rinsed with deionized water, and dried in air at $40^{\circ} \mathrm{C}$ for subsequent analyses.

\subsection{Analytical methods}

All analyses of fluid and solid material were performed at the Woods Hole Oceanographic Institution unless otherwise noted. During each sampling event, fluids were analyzed for $\mathrm{pH}\left(25^{\circ} \mathrm{C}\right)$, major ions, and dissolved $\mathrm{SiO}_{2}, \mathrm{H}_{2}, \mathrm{CH}_{4}$, and total $\mathrm{CO}_{2}\left(\Sigma \mathrm{CO}_{2}=\mathrm{CO}_{2}+\right.$ $\left.\mathrm{HCO}_{3}{ }^{-}+\mathrm{CO}_{3}{ }^{2-}\right)$. Most species were analyzed in duplicate samples. The $\mathrm{pH}\left(25^{\circ} \mathrm{C}\right)$ was measured using a $\mathrm{Ag} / \mathrm{AgCl}$ micro-combination reference electrode. Major ions ( $\mathrm{Na}, \mathrm{K}, \mathrm{Ca}, \mathrm{Mg}, \mathrm{Cl}$ ) were analyzed by ion chromatography. Dissolved $\mathrm{SiO}_{2}$ was measured spectrophotometrically at 815 $\mathrm{nm}$ wavelength using the heteropoly blue method (Woods and Mellon, 1941). Dissolved $\mathrm{H}_{2}$ and 
$\mathrm{CH}_{4}$ were quantified following a headspace extraction using a gas chromatograph (GC) equipped with a $5 \AA$, molecular sieve packed column and thermal conductivity and flame ionization detectors. Dissolved $\Sigma \mathrm{CO}_{2}$ concentrations were determined using a purge and trap apparatus interfaced directly to a gas chromatograph equipped with a Porapak-Q packed column and thermal conductivity detector. Complete extraction of all carbonate species as $\mathrm{CO}_{2}$ was ensured by the presence of 25 wt. \% phosphoric acid in the purge cell. Gas chromatography-mass spectrometry (GC-MS) was used to assess the extent to which the ${ }^{13} \mathrm{C}$ label was incorporated by $\mathrm{CH}_{4}$ produced during the experiment. This technique was used to detect incorporation of ${ }^{13} \mathrm{C}$ into $\mathrm{CH}_{4}$ on a percent scale.

During the experiment, the initial harzburgite powder was cemented by precipitating secondary minerals, forming a coherent material that allowed polished thin sections of the solid products to be prepared. Thin sections were prepared at High Mesa Petrographics (Los Alamos, $\mathrm{NM}$ ) in oil to avoid dissolution of water-soluble phases and to minimize oxidation of $\mathrm{Fe}(\mathrm{II})$ bearing minerals. Thin sections were inspected with a petrographic microscope in transmitted and reflected light, and with a Hitachi TM3000 scanning electron microscope (SEM) in backscattered electron (BSE) mode. The SEM was coupled to a Bruker-Quantax 70 energy dispersive $\mathrm{X}$-ray spectrometer (EDS) and was operated at a $15 \mathrm{kV}$ accelerating voltage under low vacuum to allow for analysis of uncoated thin sections. High resolution BSE images were obtained on Ptcoated thin sections using a Zeiss Supra 40VP scanning electron microscope operated at a $10 \mathrm{kV}$ accelerating voltage (Marine Biological Laboratory). Volumes of the starting material and solid reaction products were measured with a Micromeritics AccuPyc II 1340 helium pycnometer and were used to calculate the density change during alteration. Bulk magnetic susceptibility was determined at $0.465 \mathrm{kHz}$ using a Bartington MS2B Dual Frequency Sensor. Minerals were identified with a Horiba Jobin-Yvon LabRAM HR confocal Raman spectrometer. A 473 nm laser was used to identify clinopyroxene and its associated secondary minerals, while a $633 \mathrm{~nm}$ laser was used to identify all other minerals. Raman measurements were carried out on both thin section and powdered samples using a $600 \mathrm{~mm}^{-1}$ grating, $100 \mu \mathrm{m}$ confocal hole, and $100 \mu \mathrm{m}$ slit width. Spectra were typically acquired in the $150-1350 \mathrm{~cm}^{-1}$ region, and if necessary, in the $3200-4000 \mathrm{~cm}^{-1}$ region to distinguish serpentine group minerals. The spectra presented represent the average of two acquisitions collected for 5-60 s each. Major element mineral compositions were measured with a JEOL-JXA-8200 'SuperProbe' (Massachusetts Institute of Technology) 
and a JEOL-JXA-8530F 'Hyperprobe' Field-Emission (Yale University) electron probe microanalyzer. Analyses were carried out using a $15 \mathrm{kV}$ accelerating voltage and $10 \mathrm{nA}$ beam current. The beam diameter was set to 7-10 $\mu \mathrm{m}$ for analyses of hydrous silicates and carbonates to avoid volatile loss, and was fully-focused for analyses of primary silicates, oxides, and sulfides. To quantify the proportion of secondary minerals, simultaneous thermogravimetric (TG) analysis and differential thermal analysis (DTA) of the solid products was conducted at Tohoku University (Sendai, Japan) using a Rigaku ThermoPlus EVOII TG8120 differential thermogravimetric analyzer. Approximately $1 \mathrm{~g}$ of the solid reaction products was crushed to a fine powder using an agate mortar and pestle. A $39.7 \mathrm{mg}$ subsample of the crushed solids was then selected for subsequent thermal analysis. The solids were heated in air atmosphere at a rate of $10^{\circ} \mathrm{C} / \mathrm{min}$ from 20 to $1200^{\circ} \mathrm{C}$, and their mass loss measured at a resolution of $0.1 \mu \mathrm{g}$. The temperature difference between the sample and a reference material was simultaneously measured and used to calculate heat flow. Exothermic and endothermic reactions such as devolatilization of carbonates or phase transformations can be identified with DTA.

\subsection{Thermodynamic calculations}

The equilibrium distribution of aqueous species and in situ $\mathrm{pH}$ were calculated from thermodynamic data using the EQ3/6 software code (Wolery, 1992). Thermodynamic calculations were performed using a customized thermodynamic database prepared at $35 \mathrm{MPa}$ with SUPCRT92 (Johnson et al., 1992), details of which can be found in Klein et al. (2009), McCollom and Bach (2009), and Klein et al. (2013).

During the initial $\mathrm{CO}_{2}$-poor phase of the experiment (samples 1-6), the in situ $\mathrm{pH}$ was calculated by speciating the measured fluid composition and $\mathrm{pH}$ at $25^{\circ} \mathrm{C}$, and then re-speciating the fluid composition at the experimental conditions while conserving mass. The same approach could not be used for fluids sampled after the addition of $\mathrm{CO}_{2}$ due to degassing of $\mathrm{CO}_{2}$ during the $\mathrm{pH}$ measurement, which led to a high degree of uncertainty in the measured $\mathrm{pH}\left(25^{\circ} \mathrm{C}\right)$ values. To circumvent these uncertainties, the in situ $\mathrm{pH}$ was calculated for samples 7-12 by assuming equilibrium between dolomite and the fluid at in situ conditions. This assumption is supported by the presence of euhedral dolomite crystals at the end of the experiment, and rapid dolomite precipitation at temperatures $>200^{\circ} \mathrm{C}$ (Arvidson and Mackenzie, 1997). 


\section{RESULTS}

\subsection{Fluid chemistry during $\mathrm{CO}_{2}$-poor serpentinization}

Large and rapid changes in fluid chemistry were observed during the initial $\mathrm{CO}_{2}$-poor stage of the experiment (Figure 2.1, Table 2.1). Alteration of harzburgite resulted in a $\mathrm{pH}\left(25^{\circ} \mathrm{C}\right)$ increase from 7.4 at the beginning of the experiment to 11.0 immediately before the $\mathrm{CO}_{2}$ injection. Considerable amounts of $\mathrm{H}_{2(a q)}$ were generated during the first 7367 hours of reaction before concentrations plateaued at $63 \mathrm{mmol} / \mathrm{kg}$. The concentration of $\mathrm{CH}_{4(a q)}$ increased to 69 $\mu \mathrm{mol} / \mathrm{kg}$ during the same time period. Dissolved $\mathrm{SiO}_{2}$ concentrations increased to $0.33 \mathrm{mmol} / \mathrm{kg}$ within the first 479 hours of reaction, and subsequently decreased to $\sim 0.02 \mathrm{mmol} / \mathrm{kg}$ after 7367 hours. Concentrations of dissolved Ca showed a slight decrease from 30 to $24 \mathrm{mmol} / \mathrm{kg}$, while concentrations of $\mathrm{Na}, \mathrm{K}$, and $\mathrm{Cl}$ increased slightly during serpentinization and likely reflect the uptake of water into hydrous minerals. Except for a large and anomalous increase in the $\mathrm{Mg}$ concentration up to $28 \mathrm{mmol} / \mathrm{kg}$ at 3865-7367 hours, measured $\mathrm{Mg}$ concentrations remained below $<0.1 \mathrm{mmol} / \mathrm{kg}$ in all other samples during the $\mathrm{CO}_{2}$-poor stage of the experiment. Since no other species exhibited anomalous concentrations at 3865-7367 hours, we speculate that the high $\mathrm{Mg}$ values for samples 4 and 5 do not reflect the in situ fluid composition, but are likely a result of sub-micrometer brucite grains passing through or around the fritted filter attached to the exit tube during sampling. Since brucite exhibits retrograde solubility, it is conceivable that small brucite grains dissolve and release $\mathrm{Mg}^{2+}$ as fluids cool. Thus, the anomalous $\mathrm{Mg}$ concentrations should be interpreted with caution. At the end of the $\mathrm{CO}_{2}$-poor stage of the experiment, the dissolved $\Sigma \mathrm{CO}_{2}$ concentration was $0.06 \mathrm{mmol} / \mathrm{kg}$.

\subsection{Fluid chemistry during carbonation}

The measured concentration of dissolved $\Sigma \mathrm{CO}_{2}$ was $195 \mathrm{mmol} / \mathrm{kg} 4$ hours after the injection. Concentrations of $\Sigma \mathrm{CO}_{2}$ then decreased with time, reaching a minimum of $43 \mathrm{mmol} / \mathrm{kg}$ in the final sample of the experiment, 5907 hours after the injection (Figure 2.1, Table 2.1). Four hours after the $\mathrm{CO}_{2}$ injection, the $\mathrm{pH}\left(25^{\circ} \mathrm{C}\right)$ decreased to 5.8 from a value of 11.0 before injection, and further decreased to 4.9 after 119 hours of reaction. The carbonation period revealed higher concentrations of dissolved $\mathrm{SiO}_{2}, \mathrm{Mg}$, and $\mathrm{Ca}$ relative to fluids during the $\mathrm{CO}_{2}$ poor serpentinization stage. Concentrations of dissolved $\mathrm{SiO}_{2}$ and $\mathrm{Mg}$ increased to 0.54 and 4.75 $\mathrm{mmol} / \mathrm{kg}$, respectively, 4 hours after the $\mathrm{CO}_{2}$ injection. Concentrations of dissolved Ca decreased 
to $23 \mathrm{mmol} / \mathrm{kg}$ within the same time period, but subsequently increased to $32 \mathrm{mmol} / \mathrm{kg}$ after 5907 hours of reaction with the $\mathrm{CO}_{2}$-rich fluid. Concentrations of dissolved $\mathrm{H}_{2}$ and $\mathrm{CH}_{4}$ initially decreased after the $\mathrm{CO}_{2}$ injection, primarily due to dilution with the added fluid. Dissolved $\mathrm{CH}_{4}$ concentrations subsequently increased at a rate that was virtually identical to the rate prior to the $\mathrm{CO}_{2}$ injection, while $\mathrm{H}_{2(a q)}$ concentrations continued to decrease and reached a minimum of 0.9 $\mathrm{mmol} / \mathrm{kg}$ in the final sample. Despite the increase in $\mathrm{CH}_{4(a q)}$ concentrations during the carbonation period, ${ }^{13} \mathrm{CH}_{4(a q)}$ was observed at natural abundances $(\sim 1 \%)$ in the final sample, indicating that the ${ }^{13} \mathrm{C}$ from the injected ${ }^{13} \mathrm{CO}_{2}$ was not incorporated into $\mathrm{CH}_{4}$ to a significant extent.

\subsection{Petrography of the solid reaction products}

A summary of the petrographic observations is presented in Table 2.2. The arrangement of secondary minerals resembles pseudomorphic textures in serpentinized oceanic peridotites from natural environments. Serpentine minerals and other minor phases form coronas around primary silicate crystals and appear to conserve their shape. Unlike typical pseudomorphic serpentinite textures, significant pore space is present, allowing for enhanced fluid access to primary mineral surfaces (Figure 2.2a). Fine chrysotile fibers, $<1$ to $20 \mu \mathrm{m}$ in length, are observed to coat the original primary mineral surfaces and extend into the interstitial space (Figure 2.4a).

Primary silicates were partially to completely replaced by secondary minerals during the experiment. Thin section image analysis reveals rare olivine ( $<0.1$ vol. \%), up to $70 \mu \mathrm{m}$ in diameter, and no relict orthopyroxene. In contrast, relict clinopyroxene is relatively abundant and represents $\sim 1$ vol. $\%$ of the final assemblage (Figure $2.2 \mathrm{a}$ ).

Where present, olivine grains are rimmed by a continuous layer of dolomite, 10-20 $\mu \mathrm{m}$ across, followed by a layer of lizardite as identified by Raman spectroscopy (Figures 2.2b, 2.3). Anhedral magnetite occurs at the interface between dolomite and lizardite (Figures 2.2b, 2.3). Areas where olivine is completely altered to secondary minerals are composed of lizardite + chrysotile + magnetite \pm dolomite. Dolomite occurs as subhedral to euhedral crystals at the centers of the replaced olivine and is associated with anhedral magnetite (Figure 2.2d,e). Where dolomite is not present, magnetite occurs as subhedral to euhedral crystals, up to $30 \mu \mathrm{m}$ in diameter, at the center and rim of completely serpentinized olivine (Figure 2.4c). 
In contrast to olivine, orthopyroxene underwent complete alteration during the experiment. Orthopyroxene is chiefly replaced by lizardite and minor chrysotile. The pseudomorphic products typically appear compositionally zoned, with clearly distinguishable cores and rims in back scattered electron images (Figure 2.4d). Neither magnetite nor carbonate occurs in the cores; however, magnetite is found in the rims of completely altered orthopyroxene. Brucite and talc were not detected in the solid products by either optical, Raman, or electron microprobe analyses.

Clinopyroxene was less altered during the experiment compared to olivine and orthopyroxene. It occurs as relict grains, up to $135 \mu \mathrm{m}$ in diameter, rimmed by serpentine minerals with a sheet-like or platy structure indicative of lizardite (Figure 2.4e,f). Relict clinopyroxene overgrown by dolomite is not observed. Raman spectra show that a minor phase may occur with serpentine after clinopyroxene, as evidenced by the presence of shoulders on Raman bands of serpentine and by an unidentified band at $\sim 538 \mathrm{~cm}^{-1}$ (Figure 2.3). However, unequivocal identification was precluded due to the fine-grained nature of the secondary products. Clinopyroxene and olivine exhibit numerous etch pits and embayments resulting from dissolution reactions (Figures 2.2b, 2.4e). Etch pits are oriented in the direction of cleavage traces in clinopyroxene.

Chrysotile fibers are observed to coat the surface of Cr-spinel (Figure $2.4 \mathrm{~g}$ ). With the exception of rare grains rimmed by magnetite, Cr-spinel shows little, if any, signs of dissolution. In contrast to the unaltered harzburgite, which contained the primary sulfides pentlandite and pyrrhotite, the serpentinized and carbonate-altered reaction products contain secondary millerite and minor pyrite as determined by electron microprobe and EDS analyses (Figure 2.4h). Sulfides are $<1$ to $5 \mu \mathrm{m}$ across and are typically associated with magnetite.

In addition to carbonate rimming olivine, subhedral to euhedral carbonate 5-75 $\mu \mathrm{m}$ in diameter occurs in the centers of completely replaced primary silicates and in the interstitial pore spaces (Figures 2.2c-e, 2.4b, 2.5). Raman spectroscopy reveals that carbonate is compositionally zoned in most instances, with dolomite rimming cores composed of Ca-dolomite $\pm \mathrm{Mg}$-calcite (Figures 2.5, 2.6). Ca-dolomite exhibits sharp, symmetric Raman bands, indicating that it is a separate phase and not a mixture of dolomite and $\mathrm{Mg}$-calcite. Ca-dolomite and Mg-calcite in the carbonate interiors exhibit numerous dissolution pits, whereas dolomite rims appear pit-free with sharp, smooth edges. 


\subsection{Secondary mineral chemistry}

Serpentine minerals exhibit $\mathrm{Al}_{2} \mathrm{O}_{3}, \mathrm{FeO}, \mathrm{NiO}$, and $\mathrm{Cr}_{2} \mathrm{O}_{3}$ contents that reflect compositional differences in their primary silicate precursors (Table 2.3, Figure 2.7). Serpentine after clinopyroxene is significantly richer in $\mathrm{Al}_{2} \mathrm{O}_{3}$ and $\mathrm{FeO}$ than serpentine after olivine or orthopyroxene, with $\mathrm{Al}_{2} \mathrm{O}_{3}$ contents of 3.5-5.4 wt. \% and Mg\#s of 84.4-89.9. The elevated $\mathrm{Al}_{2} \mathrm{O}_{3}$ contents suggest that a minor aluminous phase may be intergrown with serpentine, such as chlorite or Mg-smectite. This aluminous mineral is likely the unidentified phase in the Raman spectra of serpentine after clinopyroxene (Figure 2.3). A previous laboratory study has documented the formation of chlorite during serpentinization of harzburgite at $300^{\circ} \mathrm{C}$ (Klein et al., 2015a).

Dolomite contains $55 \pm 2$ mol. $\% \mathrm{CaCO}_{3}$ and is enriched in Ca relative to its ideal endmember composition. It also contains a significant siderite component, with $4.6 \pm 0.3 \mathrm{~mol} \%$ $\mathrm{FeCO}_{3}$, and contains minor amounts of $\mathrm{Mn}\left(0.8 \pm 0.1 \mathrm{~mol} . \% \mathrm{MnCO}_{3}\right)$. Ca-dolomite consists of $66 \pm 3$ mol. $\% \mathrm{CaCO}_{3}$, has more variable Fe contents $\left(2.8 \pm 1.5 \mathrm{~mol} . \% \mathrm{FeCO}_{3}\right)$ and is slightly enriched in $\mathrm{Mn}\left(1.0 \pm 0.3 \mathrm{~mol} . \% \mathrm{MnCO}_{3}\right)$. Raman analyses reveal systematic shifts in the $\mathrm{CO}_{3}$ band positions with changes in composition. The $\mathrm{v} 1$ and $\mathrm{v} 4$ internal modes and two translational lattice modes are systematically shifted to lower wavenumbers with increasing substitution of $\mathrm{Ca}$ into dolomite (Figure 2.6). The observed correlation between band position and Ca-content are consistent with those previously reported for Ca-rich dolomites (e.g., Mposkos et al., 2006). Mgcalcite formed during the experiment has grain sizes smaller than $\sim 5 \mu \mathrm{m}$, precluding electron microprobe analyses of Mg-calcite identified by Raman spectroscopy.

\subsection{Bulk physical and chemical properties}

The bulk density of the starting solids decreased from $3.33 \mathrm{~g} / \mathrm{cm}^{3}$ to $2.67 \mathrm{~g} / \mathrm{cm}^{3}$ in the alteration products recovered at the end of the experiment. At the same time, the volume-specific magnetic susceptibility increased from $4.90 \times 10^{-4}$ to $1.35 \times 10^{-2}$ S.I. as magnetite formed. TG analysis of the solid reaction products revealed a bulk volatile content of 12.9 wt. $\%$ and a serpentine content of $89 \mathrm{wt}$. \% (Figure 2.8). Since the temperature of serpentine dehydroxylation overlaps with that of chlorite and smectite, mass loss from these minerals cannot be distinguished. Therefore, the estimated proportion of serpentine represents a maximum amount. A mass loss of $0.77 \mathrm{wt}$. \% was also detected from the thermal decomposition of carbonate 
minerals, corresponding to a dolomite content of $1.6 \mathrm{wt}$ \%. Because dolomite in the experiment has a variable and more Ca-rich composition than its stoichiometric formula, this value represents a minimum due to the higher molecular weight of Ca compared with $\mathrm{Mg}$.

\section{DISCUSSION}

\subsection{Reaction pathways during serpentinization of harzburgite in a $\mathrm{CO}_{2}$-poor system}

The sequence of reactions taking place during serpentinization and mineral carbonation can be assessed through the use of activity-activity diagrams that depict mineral stability relations at the experimental temperature and pressure conditions. The speciated in situ fluid compositions for the first three fluid samples (98-1655 hours) fall within the stability field of serpentine in an activity diagram for the $\mathrm{MgO}-\mathrm{CaO}-\mathrm{SiO}_{2}-\mathrm{H}_{2} \mathrm{O}-\mathrm{CO}_{2}$ system (Figure 2.9a), suggesting that serpentine formed early during serpentinization, while brucite and talc were unstable (cf. Klein et al., 2015a). This suggests that olivine and orthopyroxene underwent hydration to serpentine according to the following reactions written to conserve $\mathrm{Mg}$ in solution:

$3 \mathrm{Mg}_{2} \mathrm{Si}_{2} \mathrm{O}_{6}+4 \mathrm{H}_{2} \mathrm{O}=2 \mathrm{Mg}_{3} \mathrm{Si}_{2} \mathrm{O}_{5}(\mathrm{OH})_{4}+2 \mathrm{SiO}_{2(a q)}$

orthopyroxene serpentine

and

$$
\underset{\text { olivine }}{3 \mathrm{Mg}_{2} \mathrm{SiO}_{4}}+\mathrm{SiO}_{2(a q)}+4 \mathrm{H}_{2} \mathrm{O}=\underset{3}{2 \mathrm{Mg}_{3} \mathrm{Si}_{2} \mathrm{O}_{5}(\mathrm{OH})_{4}}
$$

where olivine, orthopyroxene, and serpentine represent magnesium endmember components of mineral solid solutions.

Dissolution of orthopyroxene releases dissolved $\mathrm{SiO}_{2}$, which is available to react with olivine to form serpentine. The initial increase in $\mathrm{SiO}_{2(\mathrm{aq})}$ activity from 98 to 479 hours (samples 1 to 2, Figure 2.9a) may suggest that olivine and orthopyroxene reacted at a molar rate of less than 2:1 (olivine:orthopyroxene) during the early stages of serpentinization. Since olivine was $\sim 4$ times more abundant than orthopyroxene in the starting material on a molar basis, orthopyroxene must have been consumed prior to olivine in the experiment. The decrease in $\mathrm{SiO}_{2(\mathrm{aq})}$ activity 
after 479 hours (sample 2 to 5, Figure 2.9a) possibly indicates that serpentinization of olivine became more dominant as the amount of orthopyroxene decreased, and with it the supply of $\mathrm{SiO}_{2}$. In the latter part of the $\mathrm{CO}_{2}$-poor stage, $\mathrm{SiO}_{2(a q)}$ activities dropped sufficiently to stabilize both serpentine and brucite, consistent with the hydration of olivine according to the simplified reaction for Mg-endmembers:

$$
\underset{\text { olivine }}{2 \mathrm{Mg}_{2} \mathrm{SiO}_{4}}+3 \mathrm{H}_{2} \mathrm{O}=\underset{\text { serpentine }}{\mathrm{Mg}_{3} \mathrm{Si}_{2} \mathrm{O}_{5}(\mathrm{OH})_{4}}+\underset{\text { brucite }}{\mathrm{Mg}(\mathrm{OH})_{2}}
$$

Fluid speciation calculations suggest that clinopyroxene was slightly undersaturated during the early phases of the experiment when orthopyroxene and olivine reacted simultaneously (Figure 2.9a). It subsequently became part of the stable mineral assemblage as orthopyroxene was consumed, accompanied by a decrease in $\mathrm{SiO}_{2(a q)}$ activity and an increase in $\mathrm{Ca}^{2+} /\left(\mathrm{H}^{+}\right)^{2}$ activity. Orthopyroxene was likely completely consumed by the end of the $\mathrm{CO}_{2}$-poor serpentinization stage when fluids reached serpentine-brucite-clinopyroxene equilibrium as suggested by speciation calculations (sample 6, Figure 2.9a). The fluid speciation of sample 6 also suggests that the fluid was saturated with calcite prior to the $\mathrm{CO}_{2}$ injection (Figure $2.9 \mathrm{~b}$ ). Since a carbon source was not added initially to the system, $\mathrm{CO}_{2}$ required for calcite formation must have come from the harzburgite protolith or atmospheric $\mathrm{CO}_{2}$ in the starting fluid. The presence of calcite at the end of the $\mathrm{CO}_{2}$-poor serpentinization stage is consistent with a previous experimental study that generated calcite during serpentinization of a harzburgite xenolith from the Meerfelder Maar at the same temperature and pressure conditions (Klein et al., 2015a).

Significant quantities of $\mathrm{H}_{2(a q)}$ were generated by the oxidation of ferrous iron in the $\mathrm{FeO}$ component of olivine and orthopyroxene to ferric iron in the $\mathrm{Fe}_{2} \mathrm{O}_{3}$ component of serpentine and magnetite according to the reaction:

$$
\begin{array}{lc}
2 \mathrm{FeO}+\mathrm{H}_{2} \mathrm{O}= & \mathrm{Fe}_{2} \mathrm{O}_{3}+\mathrm{H}_{2(a q)} \\
\text { primary } & \text { secondary } \\
\text { mineral } & \text { mineral }
\end{array}
$$


The starting protolith contained 7.67 wt. $\% \mathrm{FeO}$ and negligible $\mathrm{Fe}_{2} \mathrm{O}_{3}$ (Klein et al., 2015a). If it is assumed that $\mathrm{Fe}^{3+} / \Sigma \mathrm{Fe}=2 / 3$ in completely serpentinized peridotite (Marcaillou et al., 2011; Andreani et al., 2013; Klein et al., 2014) and that $\mathrm{H}_{2(a q)}$ was not consumed to any significant extent during the experiment by secondary reactions, then reaction 5 indicates that complete alteration of $18.19 \mathrm{~g}$ protolith should generate 6.4 mmoles $\mathrm{H}_{2(a q)}$. Since only 1.9 mmoles $\mathrm{H}_{2(a q)}$ were produced after 14569 hours of reaction, and after correcting for the removal of $\mathrm{H}_{2(a q)}$ during sampling, this would suggest that $\sim 30 \%$ of the harzburgite underwent serpentinization. However, because the solid products could not be analyzed prior to the $\mathrm{CO}_{2}$ injection without disturbing the experiment, the $\mathrm{Fe}_{2} \mathrm{O}_{3}$ content of the serpentinized harzburgite could not be verified. If the $\mathrm{Fe}^{3+} / \Sigma \mathrm{Fe}$ of the reaction products was less than $2 / 3$, then the extent of serpentinization would be higher than the estimated value.

Reaction progress can also be approximated from the increase in magnetic susceptibility resulting from the formation of magnetite during serpentinization (Malvoisin et al., 2012). Based on the measured magnetic susceptibility of the solid products, experimental relations between magnetic susceptibility and serpentinization suggest that at least $23 \%$ of the harzburgite underwent serpentinization (Malvoisin et al., 2012). This value is roughly consistent with the reaction progress estimated from the amount of $\mathrm{H}_{2(a q)}$ generated assuming the $\mathrm{Fe}^{3+} / \Sigma \mathrm{Fe}$ of the reaction products was $2 / 3$, tentatively indicating that abundant olivine likely remained at the end of the serpentinization stage. Given that these results suggest incomplete serpentinization of the protolith, the observed decrease in the rate of $\mathrm{H}_{2(a q)}$ production during the experiment (Figure $2.1 \mathrm{c}$ ) is not the result of complete primary mineral consumption, but instead reflects reduced fluid access to primary olivine mineral surfaces in response to armoring by alteration products (cf. Klein et al., 2015a).

In summary, the mineral assemblage prior to the injection of the $\mathrm{CO}_{2}$-enriched fluid likely consisted of the primary minerals olivine, clinopyroxene, and spinel, in addition to the secondary minerals serpentine, brucite, magnetite, calcite, Ni-sulfides, and possibly chlorite. Primary orthopyroxene was most likely completely consumed. The fluid associated with this disequilibrium mineral assemblage was strongly alkaline, rich in dissolved $\mathrm{Ca}$ and $\mathrm{H}_{2}$, but depleted in dissolved $\mathrm{Si}, \mathrm{Mg}$, and $\Sigma \mathrm{CO}_{2}$. 


\subsection{Reaction pathways during mineral carbonation in a $\mathrm{CO}_{2}$-rich system}

The addition of acidity as $\mathrm{CO}_{2}$ and the precipitation of carbonate minerals resulted in a

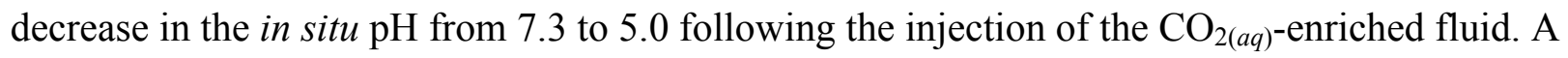
lower $\mathrm{pH}$ can promote the dissolution of $\mathrm{Mg}$-hydroxides and silicates present at the end of the serpentinization stage (Klein and McCollom, 2013). Speciation calculations suggest that brucite, olivine, and clinopyroxene were unstable under these conditions. Observed increases in the concentrations of dissolved $\mathrm{Mg}, \mathrm{SiO}_{2}$, and $\mathrm{Ca}$ after the $\mathrm{CO}_{2}$ injection are consistent with dissolution of these minerals according to the simplified reactions:

$\mathrm{Mg}(\mathrm{OH})_{2}+2 \mathrm{H}^{+}=\mathrm{Mg}^{2+}+2 \mathrm{H}_{2} \mathrm{O}$

brucite

$\mathrm{Mg}_{2} \mathrm{SiO}_{4}+4 \mathrm{H}^{+}=2 \mathrm{Mg}^{2+}+\mathrm{SiO}_{2(a q)}+2 \mathrm{H}_{2} \mathrm{O}$

olivine

$\mathrm{CaMg}\left(\mathrm{SiO}_{3}\right)_{2}+4 \mathrm{H}^{+}=\mathrm{Ca}^{2+}+\mathrm{Mg}^{2+}+2 \mathrm{SiO}_{2(a q)}+2 \mathrm{H}_{2} \mathrm{O}$

clinopyroxene

$\mathrm{SiO}_{2(\mathrm{aq})}$ concentrations initially increased rapidly following the $\mathrm{CO}_{2}$ injection and subsequently plateaued (Figure 2.1). The initial rapid increase in $\mathrm{SiO}_{2(\mathrm{aq})}$ concentrations observed after the $\mathrm{CO}_{2}$ injection may result from slow rates of serpentine precipitation relative to olivine dissolution under conditions of high carbonate alkalinity (Lafay et al., 2014), which would allow $\mathrm{SiO}_{2}$ to accumulate in solution. The subsequent plateau in $\mathrm{SiO}_{2(\mathrm{aq})}$ concentrations may reflect serpentine formation after clinopyroxene, a decrease in olivine and clinopyroxene dissolution rates over time, or a combination of these processes.

${ }^{13} \mathrm{CH}_{4(a q)}$ was observed at natural abundances $(\sim 1 \%)$ at the end of the $\mathrm{CO}_{2}$-rich stage of the experiment, indicating that the ${ }^{13} \mathrm{C}$ from the injected ${ }^{13} \mathrm{CO}_{2}$ was not incorporated into $\mathrm{CH}_{4}$ to a significant extent. This signifies that an undetectable amount of $\mathrm{CO}_{2}$ was reduced to $\mathrm{CH}_{4}$, despite the strong thermodynamic drive for $\mathrm{CH}_{4}$ formation and the presence of potential surface catalysts such as magnetite, Cr-spinel, and Ni-sulfides (Foustoukos and Seyfried, 2004; Cody et al., 2004). This result is consistent with the slow reduction of dissolved $\mathrm{CO}_{2}$ to $\mathrm{CH}_{4}$ reported in 
several previous laboratory studies (McCollom and Seewald, 2001; McCollom and Seewald, 2003; Foustoukos and Seyfried, 2004; Fu et al., 2007; McCollom and Seewald, 2007; Fu et al., 2008). Lack of labeled $\mathrm{CH}_{4}$ indicates that unlabeled $\mathrm{CH}_{4(a q)}$ measured in the experiment was derived from a source other than $\Sigma \mathrm{CO}_{2}$, likely from trace amounts of reduced carbon already present in the starting materials, such as fluid inclusions. Indeed, previous experimental studies have demonstrated the production of micromolar quantities of dissolved methane from reduced carbon compounds in powdered olivine (McCollom and Seewald, 2001; McCollom and Seewald, 2007).

\subsection{1. $\mathrm{H}_{2}$ consumption}

The decrease in dissolved $\mathrm{H}_{2}$ concentrations following $\mathrm{CO}_{2}$ injection is greater than can be accounted for by dilution with the injected fluid, indicating that $\mathrm{H}_{2}$ was consumed by subsequent reactions. A previous experimental study has documented a similar decrease in $\mathrm{H}_{2(\mathrm{aq})}$ concentrations during the reaction of serpentinized peridotite and $\mathrm{CO}_{2}$-bearing fluid (Klein and McCollom, 2013). Consumption of $\mathrm{H}_{2(a q)}$ reflects less reducing conditions during the carbonation stage of the experiment compared to before the $\mathrm{CO}_{2}$ injection. The presence of minor millerite and pyrite in the alteration products is consistent with less reducing fluids during mineral carbonation as indicated by Fe-Ni-O-S phase relations (Frost, 1985; Klein and Bach, 2009). These opaque minerals are also observed in natural mineral assemblages in carbonate-altered serpentinite, which indicate higher oxygen fugacities relative to ultramafic rocks affected only by serpentinization (Eckstrand, 1975; Frost, 1985).

We calculate that 0.72 mmoles $\mathrm{H}_{2}$ were consumed during the carbonation period after correcting for the removal of $\mathrm{H}_{2}$ during sampling. Possible reactions to explain the decrease in $\mathrm{H}_{2}$ include precipitation of graphite, formation of reduced carbon intermediaries (CO, formate, formaldehyde, methanol), formation of siderite solid solution in dolomite, and reduction of $\mathrm{Fe}(\mathrm{III})$-bearing minerals. While graphite was supersaturated in all fluid samples during the carbonation period, no graphite was detected in the solid products by optical, Raman, or electron microprobe analyses. However, it is possible that trace amounts of graphite may have formed with carbonate, which would not have been detected by the above techniques.

To estimate the amount of $\mathrm{H}_{2}$ consumed by formation of reduced carbon intermediaries, the measured fluid compositions were speciated using a thermodynamic model that allowed 
equilibrium between $\mathrm{CO}_{2}, \mathrm{CO}$, formate, formaldehyde, methanol, and $\mathrm{H}_{2}$, but not $\mathrm{CH}_{4}$. Speciation calculations indicate the formation of 0.03 mmoles of reduced carbon intermediaries in the first sample after $\mathrm{CO}_{2}$ injection. Production of these species would consume 0.05 mmoles $\mathrm{H}_{2}$, accounting for $7 \%$ of the measured $\mathrm{H}_{2}$ drop in the experiment.

$\mathrm{H}_{2}$ can also be consumed by reduction of $\mathrm{Fe}(\mathrm{III})$ to $\mathrm{Fe}(\mathrm{II})$ in the siderite component of dolomite. Association of anhedral magnetite with dolomite in the alteration products suggests that siderite formation was possibly coupled to magnetite destruction according to the reaction:

$$
\begin{aligned}
& \mathrm{Fe}_{3} \mathrm{O}_{4}+3 \mathrm{CO}_{2(a q)}+\mathrm{H}_{2(a q)}=\underset{\text { siderite }}{3 \mathrm{FeCO}_{3}}+\mathrm{H}_{2} \mathrm{O} \\
& \text { magnetite }
\end{aligned}
$$

Destruction of magnetite reflects more oxidizing conditions in serpentinite affected by talccarbonate alteration (Naldrett, 1966; Groves et al., 1974; Eckstrand, 1975). Formation of 1.6 wt. $\%$ dolomite having an average $\mathrm{FeO}$ content of 3.51 wt. \% (Table 2.3) would consume 0.06 mmoles $\mathrm{H}_{2}$ via reaction 9. Thus, siderite formation can account for $8 \%$ of the measured $\mathrm{H}_{2(\mathrm{aq})}$ drop during the experiment. Fe(II) in dolomite can also be derived from Fe(III) in solution. However, the low solubility of Fe(III) in near-neutral $\mathrm{pH}$ fluids suggests that this was not a significant source of $\mathrm{Fe}$ for siderite formation. Taken together, the formation of siderite and reduced carbon intermediates can only explain part of the decrease in $\mathrm{H}_{2(\mathrm{aq})}$ concentrations after the $\mathrm{CO}_{2}$ injection, suggesting that there is another, unidentified process responsible for consuming $\mathrm{H}_{2(\mathrm{aq})}$ during the carbonation stage of the experiment.

\subsubsection{Carbonate formation}

Dissolution of brucite and olivine released $\mathrm{Mg}$ to solution, resulting in an increase in the $\mathrm{Mg} / \mathrm{Ca}$ ratio of the fluid from $<0.01$ at the end of the $\mathrm{CO}_{2}$-poor serpentinization stage to 0.21 in the first sample taken 4 hours after the $\mathrm{CO}_{2}$ injection (Table 2.1). This rapid increase in the fluid $\mathrm{Mg} / \mathrm{Ca}$ ratio destabilized early-formed calcite and favored the formation of dolomite (Figure 2.9c). Dolomite occurs as reaction rims over relict olivine (Figure 2.2b), in the centers of completely replaced primary minerals (Figures 2.2c-e, 2.5), and in interstitial pore spaces (Figure $2.4 \mathrm{~b}$ ). The presence of dolomite coronas around relict olivine (Figure 2.2b) suggests that dolomite replaced olivine through a dissolution-precipitation reaction, such as: 


$$
\mathrm{Mg}_{2} \mathrm{SiO}_{4}+4 \mathrm{CO}_{2(a q)}+2 \mathrm{Ca}^{2+}+2 \mathrm{H}_{2} \mathrm{O}=2 \mathrm{CaMg}\left(\mathrm{CO}_{3}\right)_{2}+\mathrm{SiO}_{2(a q)}+4 \mathrm{H}^{+}
$$

olivine

dolomite

where $\mathrm{Ca}^{2+}$ is derived from the reacting fluid and from dissolution of Ca-bearing minerals such as clinopyroxene. The original external shape of the olivine appears to be preserved, indicating coupling of dissolution and precipitation reactions at the olivine-dolomite interface. Olivine exhibits abundant dissolution features, including etch pits and embayments. In addition, the interface between olivine and dolomite appears saw-tooth-shaped, reflecting heterogeneous reactivities of olivine mineral surfaces (King et al., 2014).

Where dolomite has completely replaced olivine or both olivine and brucite, it occurs as anhedral crystals enclosed by magnetite and serpentine (Figure 2.2c,d). However, in many instances, dolomite occurs as euhedral crystals surrounded by abundant void space in the centers of completely replaced primary minerals (Figure 2.2e, 2.5a,c). These euhedral crystals typically appear to have nucleated on the surrounding serpentine rim and to have grown outward into the central pore space. They are interpreted to result from carbonation of only brucite following $\mathrm{CO}_{2}$ injection. In natural serpentinite, brucite occurs in the mesh centers of serpentinized peridotite where it replaces olivine or in veins cross-cutting the mesh texture after olivine (e.g., Klein et al., 2009; Kahl et al., 2015; Schwarzenbach et al., 2016a). However, it is typically absent in carbonate-altered peridotite as a result of carbonation reactions (e.g., Hansen et al., 2005). Brucite likely formed during the $\mathrm{CO}_{2}$-poor serpentinization stage of the experiment as indicated by fluid speciation calculations. The lack of brucite in the alteration products at the end of the experiment and the presence of dolomite in the centers of completely replaced olivine where brucite is expected to occur suggest that dolomite replaced brucite following $\mathrm{CO}_{2}$ injection, according to the reaction:

$$
\mathrm{Mg}(\mathrm{OH})_{2}+2 \mathrm{CO}_{2(a q)}+\mathrm{Ca}^{2+}=\mathrm{CaMg}\left(\mathrm{CO}_{3}\right)_{2}+2 \mathrm{H}^{+}
$$

brucite dolomite

Carbonation of brucite is known to proceed rapidly relative to carbonation of silicate minerals at ambient temperature and moderate $\mathrm{P}_{\mathrm{CO}_{2}}$, resulting in nearly complete replacement to carbonate 
minerals within hours to tens of hours (Zhao et al., 2010; Harrison et al., 2013). While carbonation rates are fastest at moderate temperatures (e.g., Kelemen and Matter, 2008), it is conceivable that brucite dissolved at a faster rate than olivine during the carbonation stage of the experiment. The sharp decrease in $\Sigma \mathrm{CO}_{2(a q)}$ concentrations immediately following the $\mathrm{CO}_{2}$ injection may, therefore, be attributed to the rapid carbonation of brucite, with the subsequent decrease in the rate of $\mathrm{CO}_{2}$ consumption reflecting exhaustion of brucite and slower carbonation of olivine.

Euhedral carbonates replacing brucite are typically zoned, with rims composed of dolomite and cores composed of Ca-dolomite $\pm \mathrm{Mg}$-calcite (Figure 2.5). The Mg content of the carbonates generally increases from core to rim (Table 2.3). Dolomite in the rims appears euhedral and pit-free, suggesting that it was in equilibrium with the surrounding fluid at the end of the experiment. In contrast, $\mathrm{Ca}$-dolomite and $\mathrm{Mg}$-calcite in the interiors exhibit numerous dissolution pits, indicating that they were out of equilibrium with the fluids near the end of the experiment. The metastable persistence of $\mathrm{Ca}$-dolomite and $\mathrm{Mg}$-calcite may reflect stable formation immediately following $\mathrm{CO}_{2}$ injection when the fluid was characterized by low $\mathrm{Mg} / \mathrm{Ca}$ ratios during initial dissolution of olivine and brucite. Continued dissolution of olivine and brucite would then increase the $\mathrm{Mg} / \mathrm{Ca}$ ratio in solution and stabilize dolomite with higher $\mathrm{Mg}$ contents.

Alternatively, Ca-dolomite and Mg-calcite may have formed metastably during the carbonation period due to kinetic barriers preventing formation of the most stable carbonate phase, dolomite. Dolomite subsequently overgrew or partially replaced Ca-dolomite and Mgcalcite. Experiments conducted by Jonas et al. (2015) have shown that the replacement of calcite by Mg-bearing carbonates results in the formation of zoned reaction rims consisting of the intermediate phase dolomite surrounded by magnesite. We observed a similar zonation in our experiment, with more Ca-rich carbonates surrounded by more Mg-rich carbonates. Replacement of calcite by $\mathrm{Mg}$-bearing carbonates can also produce $\mathrm{Ca}-\mathrm{Mg}$ carbonates with a pitted texture, which results from dissolution of earlier formed phases (Katz and Matthews, 1977; Sibley, 1990; Nordeng and Sibley, 1994; Kaczmarek and Sibley, 2014; Jonas et al., 2015). A similar pitted texture is observed in Ca-dolomite and Mg-calcite in the experiment (Figure 2.5). The porosity generated by partial dissolution of $\mathrm{Mg}$-calcite and $\mathrm{Ca}$-dolomite facilitates $\mathrm{Ca}-\mathrm{Mg}$ exchange between the crystal and fluid. The dolomite rims observed during the experiment appear to have 
a lower porosity than the pitted carbonate cores. Low porosity may have limited fluid access and prevented the complete replacement of $\mathrm{Mg}$-calcite and $\mathrm{Ca}$-dolomite, preserving these phases in the carbonate interiors.

In contrast to olivine, chrysotile and lizardite appear unaltered and lack carbonate replacement rims. These findings are consistent with the stability of serpentine minerals in all fluids sampled during the experiment, with the exception of sample 7, which was taken right after the injection of the $\mathrm{CO}_{2}$-rich fluid (Figure 2.9b). Since the unreactivity of serpentine prevented it from contributing $\mathrm{Mg}$ for carbonate formation, carbonate formation was limited by the availability of $\mathrm{Mg}$ from the more reactive minerals, olivine and brucite.

\subsection{Mineral carbonation in subseafloor environments}

The majority of carbonates in oceanic peridotite examined to date formed by direct precipitation from low-temperature $\left(<150^{\circ} \mathrm{C}\right)$ fluids during shallow circulation of seawater in the upper crust or during subsurface mixing of seawater and hydrothermal fluid (Eickmann et al., 2009; Bach et al., 2011; Schwarzenbach et al., 2013). $\mathrm{CO}_{2}$ necessary for carbonate formation is thought to be sourced predominantly from seawater, but can also be derived from degassing of magmatic fluids, decomposition of organic-rich sediments, and leaching of inclusions and basaltic glass (Des Marais and Moore, 1984; Gerlach, 1989; McCollom, 2008). Carbonates formed by replacement reactions in oceanic mantle rocks are found at continental rifted margins (Alt and Shanks, 1998; Müntener and Manatschal, 2006) and oceanic core complexes (Kelemen et al., 2004; Andreani et al., 2009; Schroeder et al., 2015). Unfortunately, there are currently no serpentinite samples available from depths greater than 200 meters below the seafloor, indicating a sampling bias toward shallower sections of exhumed mantle peridotite. However, it seems likely that mineral carbonation reactions are more common in deeper sections of the crust where contributions of $\mathrm{CO}_{2}$ from magmatic degassing may be more significant (McCollom, 2008).

Calcite has been shown to replace clinopyroxene exsolution lamellae in orthopyroxene at the Newfoundland margin (Müntener and Manatschal, 2006). Calcite has also been shown to overgrow olivine and orthopyroxene at the Iberian margin, in addition to filling fractures in carbonate-serpentine breccias (Alt and Shanks, 1998). These carbonate-altered serpentinites exhibit textures similar to those in our experiment, with carbonates forming continuous reaction rims over primary silicates (Figure 2.2b). Dolomite-altered serpentinite has been documented at 
slow-spreading ocean ridges where mineral carbonation is likely facilitated by higher $\mathrm{CO}_{2}$ supply relative to magma-poor passive continental margins. Figure $2.10 \mathrm{~b}$ shows a dolomite-altered serpentinite recovered from the Atlantis Massif $\left(30^{\circ} \mathrm{N}\right.$ Mid-Atlantic Ridge) during Integrated Ocean Drilling Program Expedition 304. Dolomite crystals completely fill the center of a mesh compartment, while the surrounding serpentine appears unaltered. Andreani et al. (2009) also documented high-Mg calcite rimming relict olivine at Atlantis Massif in samples from Expedition 304 (Figure 2.10a). Similar to our experimental results, high-Mg calcite exhibits a porous reaction rim at the contact with olivine (see insert). As in our experiment, pyroxene in samples from Expedition 304 is not altered to carbonate, suggesting that olivine and brucite are more susceptible to carbonation reactions. The similarity of mineral compositions and textures in these rocks and our solid reaction products (Figure 2.2) may suggest that dolomite at the Atlantis Massif formed under conditions similar to those in our experiment. Analogous to our experiment, peridotite from the Atlantis Massif underwent serpentinization followed by carbonation of olivine and brucite to Mg-calcite and dolomite. Carbonate-altered serpentinites from Expedition 304 are only centimeters away from a talc-tremolite-chlorite rich shear zone (Hole 1309B core $11 \mathrm{R}-2,25-50 \mathrm{~cm}$ ), which likely acted as a conduit for upwelling $\mathrm{CO}_{2}$-rich fluids. Some of the $\mathrm{CO}_{2}$ was sequestered in serpentinites, preventing its release at the seafloor.

\subsection{Modeling peridotite-seawater- $\mathrm{CO}_{2}$ interactions}

A reaction path model was constructed using the EQ3/6 software code (Wolery, 1992) to simulate serpentinization and carbonation of harzburgite at $300^{\circ} \mathrm{C}$ in a mid-ocean ridge setting (Figure 2.11). This model explicitly accounts for the role of Ca during carbonation of serpentinite, thereby expanding previous modeling studies (Klein and Garrido, 2011; Bach et al., 2013). The initial rock and fluid compositions in the model were selected to match those in the experiment (Tables $2.4,2.5$ ). Analogous to the experiment, the model was conducted in two stages. In the first stage, harzburgite was equilibrated with a $\mathrm{CO}_{2}$-free solution at a fluid-to-rock mass ratio of 2. Since the fluid-to-rock mass ratio decreased during the experiment owing to the removal of fluid samples, this model is only an approximate representation of the experimental conditions. In the second stage of the model, the serpentinized harzburgite was equilibrated with a fluid containing $400 \mathrm{mmol} / \mathrm{kg} \Sigma \mathrm{CO}_{2(a q)}$ at a fluid-to-rock mass ratio of 2 to simulate the subsequent carbonation of serpentinized harzburgite. All thermodynamic calculations in the 
model were performed at $50 \mathrm{MPa}$ rather than the pressure of the experiment (35 $\mathrm{MPa}$ ) owing to the more extensive thermodynamic database available at $50 \mathrm{MPa}$. Although thermodynamic properties of carbonate minerals do depend on pressure, they are relatively insensitive to pressure changes below $100 \mathrm{MPa}$ (Klein and Garrido, 2011). To account for kinetically inhibited reactions, the formation of minerals not typically observed in mid-ocean ridge serpentinites was suppressed (amesite, antigorite, monticellite, diaspore, boehmite, corundum). All organic carbon species except for formate, formaldehyde, and methanol were also suppressed owing to the limited formation of abiotic hydrocarbons documented at laboratory timescales (e.g., McCollom and Seewald, 2001).

The reaction path model predicts that serpentine, brucite, clinopyroxene, magnetite, and chlorite form a stable mineral assemblage upon complete serpentinization of harzburgite (Figure 2.11a). The predicted mineral assemblage is consistent with fluid speciation calculations at the end of the $\mathrm{CO}_{2}$-poor stage of the experiment. Garnet is also predicted to form during initial serpentinization of harzburgite, consistent with its occurrence as a trace mineral in natural oceanic serpentinite (Beard and Hopkinson, 2000; Klein et al., 2014; Plümper et al., 2014). While no garnet was observed in the experimental products, this does not necessarily preclude its formation during the first stage of the experiment and subsequent consumption following the $\mathrm{CO}_{2}$ injection. In addition, the model closely reproduces the measured $\mathrm{pH}$ and dissolved $\mathrm{SiO}_{2}$ and $\mathrm{Mg}$ concentrations during the $\mathrm{CO}_{2}$-poor serpentinization stage (Figure 2.11b). However, the model predicts a maximum $\mathrm{H}_{2(a q)}$ concentration nearly two times higher than that measured in the experiment. Since $\mathrm{H}_{2(a q)}$ concentrations increase with increasing extent of serpentinization, the discrepancy can be attributed to incomplete serpentinization of the harzburgite protolith in the experiment. While the measured concentration of dissolved Ca decreased during the experiment, the modeled concentration remains virtually constant. This may be due to differences in the actual and predicted amounts of Ca-bearing minerals involved in controlling reactions. For instance, calcite and the portlandite $\left(\mathrm{Ca}(\mathrm{OH})_{2}\right)$ component of the brucite solidsolution likely precipitated during the experiment on the basis of fluid speciation calculations, but were not predicted to form in the model. Overall, the major mineral assemblage predicted by the model appears to be consistent with petrographic observations and fluid compositions in the experiment even though complete equilibrium was not reached. 
Subsequent reaction of serpentinized harzburgite with a $\mathrm{CO}_{2(a q)}$-rich fluid is predicted to form serpentine, magnesite, dolomite, saponite, chlorite, and graphite as a stable mineral assemblage upon complete carbonation (Figure 2.11a). The model predicts that dolomite is the first carbonate phase to form when the $\mathrm{Mg} / \mathrm{Ca}$ ratio of the fluid is low $(<0.2)$. The modeled dolomite contains a minor siderite component ( $\left.\sim 6 \mathrm{~mol}^{\circ} \% \mathrm{FeCO}_{3}\right)$, similar to the measured Fecontent of dolomite in the experiment (see Section 3.4.). Further reaction of serpentinized harzburgite and $\mathrm{CO}_{2}$-enriched fluid is predicted to increase the $\mathrm{Mg} / \mathrm{Ca}$ ratio in solution and stabilize magnesite. However, magnesite was not found among the experimental products. We attribute the lack of magnesite in the experiment to low $\mathrm{Mg} / \mathrm{Ca}$ ratios in solution resulting from clinopyroxene dissolution, while serpentine minerals remained unreactive and did not supply $\mathrm{Mg}$ to the fluid.

Clinopyroxene underwent dissolution to form serpentine during the carbonation stage of the experiment, according to the simplified reaction for Mg-endmember components of mineral solid solutions:

$$
\underset{\text { clinopyroxene }}{3 \mathrm{CaMg}\left(\mathrm{SiO}_{3}\right)_{2}}+6 \mathrm{H}^{+}=\underset{\text { serpentine }}{\mathrm{Mg}_{3} \mathrm{Si}_{2} \mathrm{O}_{5}(\mathrm{OH})_{4}}+3 \mathrm{Ca}^{2+}+4 \mathrm{SiO}_{2(a q)}+\mathrm{H}_{2} \mathrm{O}
$$

Alteration of clinopyroxene released $\mathrm{Ca}$ into solution, causing an increase in dissolved $\mathrm{Ca}$ concentrations subsequent to the $\mathrm{CO}_{2}$ injection (Figure 2.1b). At the same time, olivine and brucite dissolved via reactions 6 and 7, respectively, and supplied Mg to the fluid. However, dissolution of these Mg-bearing minerals initially provided insufficient $\mathrm{Mg}$ to stabilize magnesite in solution.

While the reaction path model predicts that serpentine is stable upon complete carbonation of harzburgite, the absolute amount of serpentine in the equilibrium mineral assemblage is less compared to before the $\mathrm{CO}_{2}$ injection, indicating a thermodynamic drive to partially dissolve serpentine during carbonation. Partial dissolution of serpentine is predicted to increase $\mathrm{Mg} / \mathrm{Ca}$ ratios sufficiently and stabilize magnesite. Yet, petrographic observations indicate that serpentine minerals in the experiment were unreactive and apparently did not undergo dissolution. This is consistent with slow rates of serpentine dissolution reported at elevated temperatures and $\mathrm{P}_{\mathrm{CO}_{2}}$ (Gerdemann et al., 2007; Hövelmann et al., 2011; Daval et al., 2013). Alteration of 
clinopyroxene coupled with the unreactivity of serpentine minerals resulted in $\mathrm{Mg} / \mathrm{Ca}$ ratios in the experiment that were lower than predicted by complete thermodynamic equilibrium in the absence of kinetic barriers. Accordingly, dolomite was the stable carbonate phase at the end of the experiment rather than magnesite.

\subsection{Implications for carbonate formation in active and fossil oceanic serpentinization systems}

Results of the thermodynamic model presented above in conjunction with previous thermodynamic studies predict that magnesite should form during reaction of oceanic serpentinite and $\mathrm{CO}_{2}$-bearing aqueous fluids (e.g., Klein and Garrido, 2011). Yet, few studies have reported magnesite in oceanic serpentinite (Gablina et al., 2006), suggesting that it is rare in subseafloor environments or has yet to be sampled. Clinopyroxene is known to remain stable during serpentinization of harzburgite due to the relatively low $a \mathrm{SiO}_{2(a q)}$ imposed by serpentine and brucite while olivine and orthopyroxene undergo complete serpentinization (e.g., Klein et al., 2013). In contrast, clinopyroxene is unstable at the elevated $a \mathrm{SiO}_{2(a q)}$ during high temperature hydrothermal alteration (e.g., Allen \& Seyfried, 2003) or during carbonation as in the present study. Serpentine can tolerate significantly higher $a \mathrm{SiO}_{2(a q)}$ and $a \mathrm{CO}_{2(a q)}$ than clinopyroxene (Figure 2.9b). As a result, the dissolution of clinopyroxene together with stable (or unreactive) serpentine maintains low $\mathrm{Mg} / \mathrm{Ca}$ ratios in solution and, thus, effectively limits magnesite formation to environments with increased $a \mathrm{CO}_{2(a q)}$ or higher $\mathrm{Mg} / \mathrm{Ca}$ ratios. The lack of serpentine replacement in carbonate-altered oceanic serpentinite (Alt and Shanks, 1998; Kelemen et al., 2004; Müntener and Manatschal, 2006; Andreani et al., 2009; Schroeder et al., 2015) indicates that carbonation of serpentine is less favorable than that of olivine and other primary silicates. This observation is consistent with slow serpentine carbonation rates documented by previous experimental studies (Gerdemann et al., 2007; Hövelmann et al., 2011; Daval et al., 2013), and indicates that both thermodynamic and kinetic constraints must be taken into account when modeling carbonation reactions in subseafloor hydrothermal environments.

Active serpentinization systems are characterized by fluids that are strongly enriched in Ca and depleted in Mg (e.g., Seyfried et al., 2015), with Ca derived from dissolution of clinopyroxene (Gamo et al., 2001; Douville et al., 2002; Kelley et al., 2005) or from reaction with surrounding mafic rocks (Bischoff and Dickson, 1975; Berndt et al., 1989). However, low- 
temperature serpentinization systems are $\mathrm{CO}_{2}$ poor due to high $\mathrm{pH}$, limiting their capacity to drive carbonation reactions. Fluids venting from unsedimented, basalt-hosted hydrothermal systems are also enriched in $\mathrm{Ca}$ and depleted in $\mathrm{Mg}$, but are enriched in $\mathrm{CO}_{2}$ (e.g., Lilley et at al., 2003; Von Damm et al., 1998). Hybrid hydrothermal systems where both mafic and ultramafic rocks interact with hydrothermal fluids enriched in $\mathrm{CO}_{2}$ and heated by a magmatic heat source may be sites of extensive carbonation in the subseafloor. However, it appears that such systems are more likely to produce $\mathrm{Ca}$-bearing carbonates than magnesite. Magnesite may form during reaction with clinopyroxene-poor ultramafic rocks, such as dunite (Klein and Garrido, 2011) or completely serpentinized peridotite that has lost most of its $\mathrm{Ca}$ to solution. Mg-rich but Ca-poor fluids are generally only associated with peridotite that has undergone complete or nearly complete serpentinization (Barnes and O'Neil, 1969). Thus, the common occurrence of magnesite in convergent tectonic settings exposed on land can be explained by the reaction of completely serpentinized peridotite with $\mathrm{CO}_{2}$-rich metamorphic or meteoric fluids.

Magnesite formation appears to be favored in settings where ultramafic rocks undergo reaction with $\mathrm{CO}_{2}$ - and $\mathrm{Mg}$-rich, but Ca-poor fluids. Evidence for the composition of fluids associated with magnesite deposits comes from ophiolites and alpine peridotite massifs undergoing active, low-temperature weathering (Barnes and O'Neil, 1969; del Real et al., 2016; Paukert et al., 2012; Quesnel et al., 2013). Magnesite also occurs in peridotite massifs that have undergone carbonation to soapstone (talc-carbonate) or listvenite (silica-carbonate) in fossil hydrothermal systems (Naldrett, 1966; Griffis, 1972; Dabitzias, 1980; Böhlke, 1989; Schandl and Wicks, 1991; Hansen et al., 2005; Robinson et al., 2005; Boschi et al., 2009; Beinlich et al., 2012; Ulrich et al., 2014; Falk and Kelemen, 2015). $\mathrm{CO}_{2}$ in the fluids is thought to derive from diagenetic and metamorphic reactions of carbon-bearing rocks (Dabitzias, 1980; Schandl and Wicks, 1991; Beinlich et al., 2012; Falk and Kelemen, 2015), meteoric water (Boschi et al., 2009; Ulrich et al., 2014), or magmatic degassing (Robinson et al., 2005).

Although magnesite is unlikely to form in significant amounts in marine serpentinization settings, at least in the shallow subseafloor accessed to date, the formation of $\mathrm{Ca}-\mathrm{Mg}$ carbonates appears to be an important process in currently active and fossil subseafloor serpentinization systems. In addition to documented occurrences of dolomite in modern seafloor serpentinites such as the Atlantis Massif, dolomite-alteration of extrusive ultramafic rocks (komatiite) is a common phenomenon documented in Archean greenstone belts (Gole et al., 1987; Hanor and 
Duchač, 1990; Schandl and Naldrett, 1992; Schandl and Wicks, 1993; van Zuilen et al., 2003; Schandl and Gorton, 2012). While the alteration history of these rocks remains difficult to reconstruct, it is possible that dolomite formation took place under conditions similar to those of the present study. The higher concentrations of $\mathrm{Ca}$ in komatiite and the high concentrations of $\mathrm{CO}_{2(a q)}$ in Archean seawater (Morse and Mackenzie, 1998) may have facilitated more widespread dolomite formation on early Earth relative to modern environments within the oceanic lithosphere.

\section{CONCLUSIONS}

The laboratory experiment presented here was designed to investigate serpentinization and carbonation pathways during alteration of harzburgite by $\mathrm{Ca}$ - and $\mathrm{CO}_{2}$-rich fluids typical of active serpentinization systems in the subseafloor. Fluid and mineral analyses suggest the following sequence of carbonate formation reactions took place during the experiment. First, minor calcite precipitated during serpentinization of harzburgite in a $\mathrm{CO}_{2}$-poor and Ca-bearing system. Second, the injection of a $\mathrm{CO}_{2(a q)}$-rich fluid caused an increase in the $\mathrm{Mg} / \mathrm{Ca}$ ratio in solution, which favored the formation of $\mathrm{Mg}-\mathrm{Ca}$ carbonates at the expense of calcite, brucite, and relict olivine, while serpentine remained unreactive. High-Mg calcite and Ca-rich dolomite initially formed as stable or metastable phases following the $\mathrm{CO}_{2 \text { (aq) }}$ injection. Lastly, dolomite formed as the final stable carbonate phase through homogeneous precipitation and/or replacement of earlier-formed $\mathrm{Mg}$-Ca carbonates.

Results from thermodynamic modeling indicate that magnesite can form during the reaction of serpentinized harzburgite and $\mathrm{CO}_{2}$-bearing aqueous fluids. Discrepancies between the predicted and observed mineral assemblages indicate that the carbonation stage of the experiment did not reach thermodynamic equilibrium. Magnesite likely did not form in the experiment due to low $\mathrm{Mg} / \mathrm{Ca}$ ratios in the fluid resulting from dissolution of clinopyroxene in combination with the lack of serpentine reactivity. This process may similarly maintain low $\mathrm{Mg} / \mathrm{Ca}$ ratios in active submarine serpentinization systems, effectively limiting magnesite formation where serpentine is stable. The formation of magnesite in oceanic settings is, therefore, likely limited to domains of Ca-poor ultramafic rocks, such as dunite or completely serpentinized peridotite, or where a sustained influx of $\mathrm{CO}_{2}$-rich fluids leads to $a \mathrm{SiO}_{2(a q)}$ that exceeds the stability of serpentine. 
Field observations, modeling results, and laboratory experiments support the idea that the formation of $\mathrm{Ca}-\mathrm{Mg}$ carbonates dominates over that of magnesite in oceanic peridotite affected by $\mathrm{CO}_{2}$-enriched hydrothermal fluids, at least in the shallow parts of the oceanic lithosphere accessed to date. Dolomite and other $\mathrm{Ca}-\mathrm{Mg}$ carbonates in oceanic serpentinite may represent a potentially significant sink for carbon that would otherwise enter the oceans. Moreover, dolomite-altered oceanic serpentinite transported into subduction zones may represent an additional carbon reservoir recycled into the deep mantle. The similarity of petrographic observations from this study with field observations suggests that the reaction pathways investigated in laboratory experiments can serve as analogs for dolomite formation in a wide range of present-day and fossil geological environments where Ca-bearing ultramafic lithologies and carbon-rich aqueous fluids interact.

\section{ACKNOWLEDGEMENTS}

We thank Jim Eckert and Nilanjan Chatterjee for assistance with electron microprobe analyses. We are grateful to Atsushi Okamoto and Ryosuke Oyanagi for performing the TGDTA analyses. This manuscript benefited greatly from constructive reviews by Romain Lafay, Esther Schwarzenbach, and an anonymous reviewer. This research was supported by the National Science Foundation through grant OCE-1427274 to F.K. and J.S.S., and a GRFP fellowship to N.G.G. 


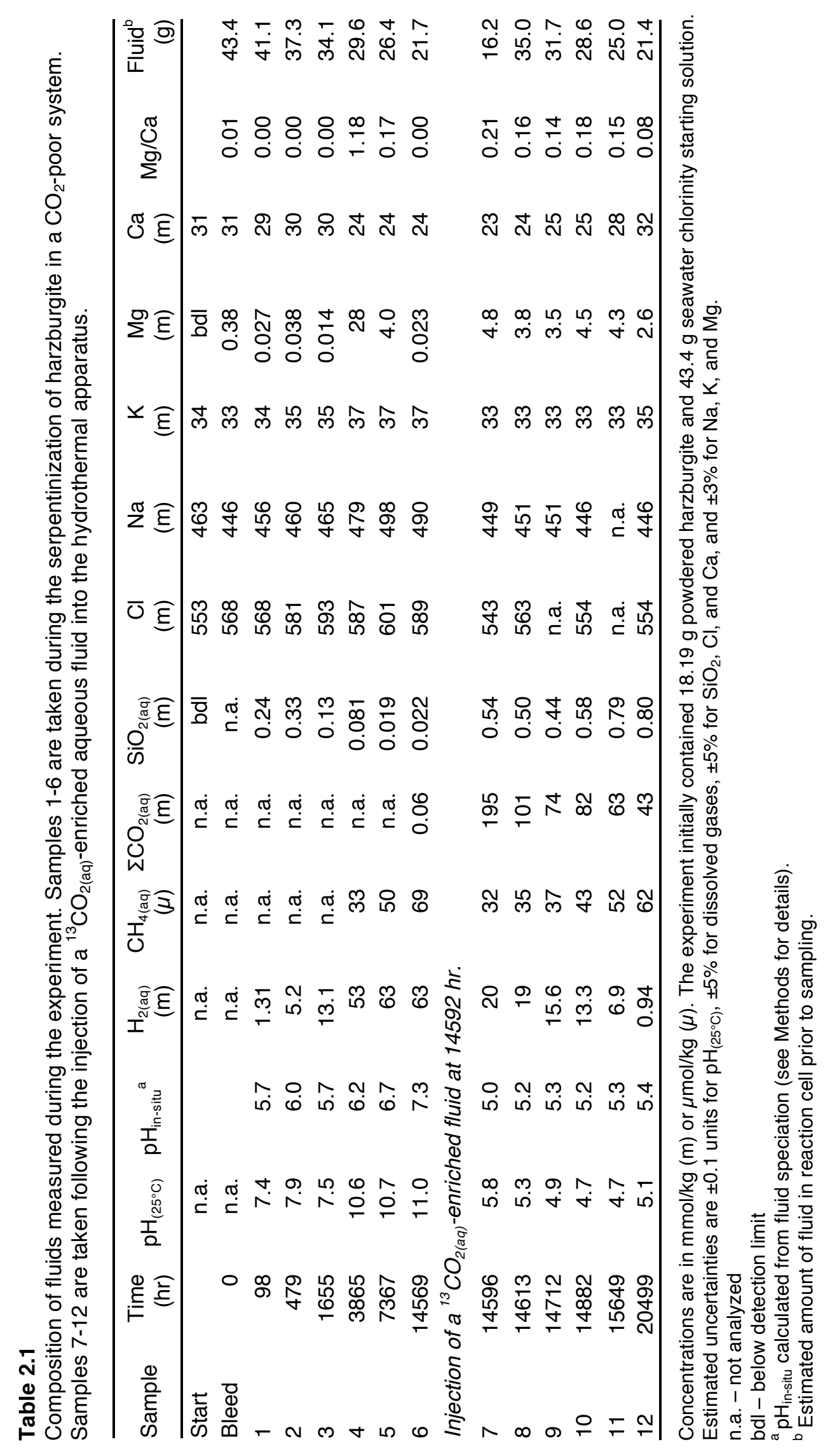


Table 2.2

Summary of petrographic observations.

\begin{tabular}{lll}
\hline Primary mineral & Secondary minerals & Comments \\
\hline Ol & Lz, Ctl, minor Mag, Brc, Dol & Dolomite replaces relict olivine and likely brucite. \\
Opx & Lz, Ctl, minor Mag & Orthopyroxene is likely consumed by the end of serpentinization. \\
Cpx & Srp, Ctl, possibly Chl & $\begin{array}{l}\text { Negligible alteration during serpentinization. Reaction } \\
\text { products likely formed following the injection of the } \mathrm{CO}_{2} \text {-rich fluid. }\end{array}$ \\
Sulfides (Pn, Po) & Mlr, Py & $\begin{array}{l}\text { Secondary sulfides are typically associated with magnetite. } \\
\text { Spl }\end{array}$ \\
None & Cal, Dol & Not altered. Chrysotile precipitates from solution and coats spinel. \\
- & & $\begin{array}{l}\text { Calcite likely precipitates from solution during serpentinization. } \\
\text { Dolomite grows over and replaces early-formed calcite. }\end{array}$
\end{tabular}

Abbreviations: Brc - brucite, Cal - calcite, Chl - chlorite, Cpx - clinopyroxene, Ctl - chrysotile, Dol - dolomite, Lz lizardite, Mag - magnetite, Mlr - millerite, OI - olivine, Opx - orthopyroxene, Pn - pentlandite, Po - pyrrhotite, Py pyrite, Srp - serpentine 


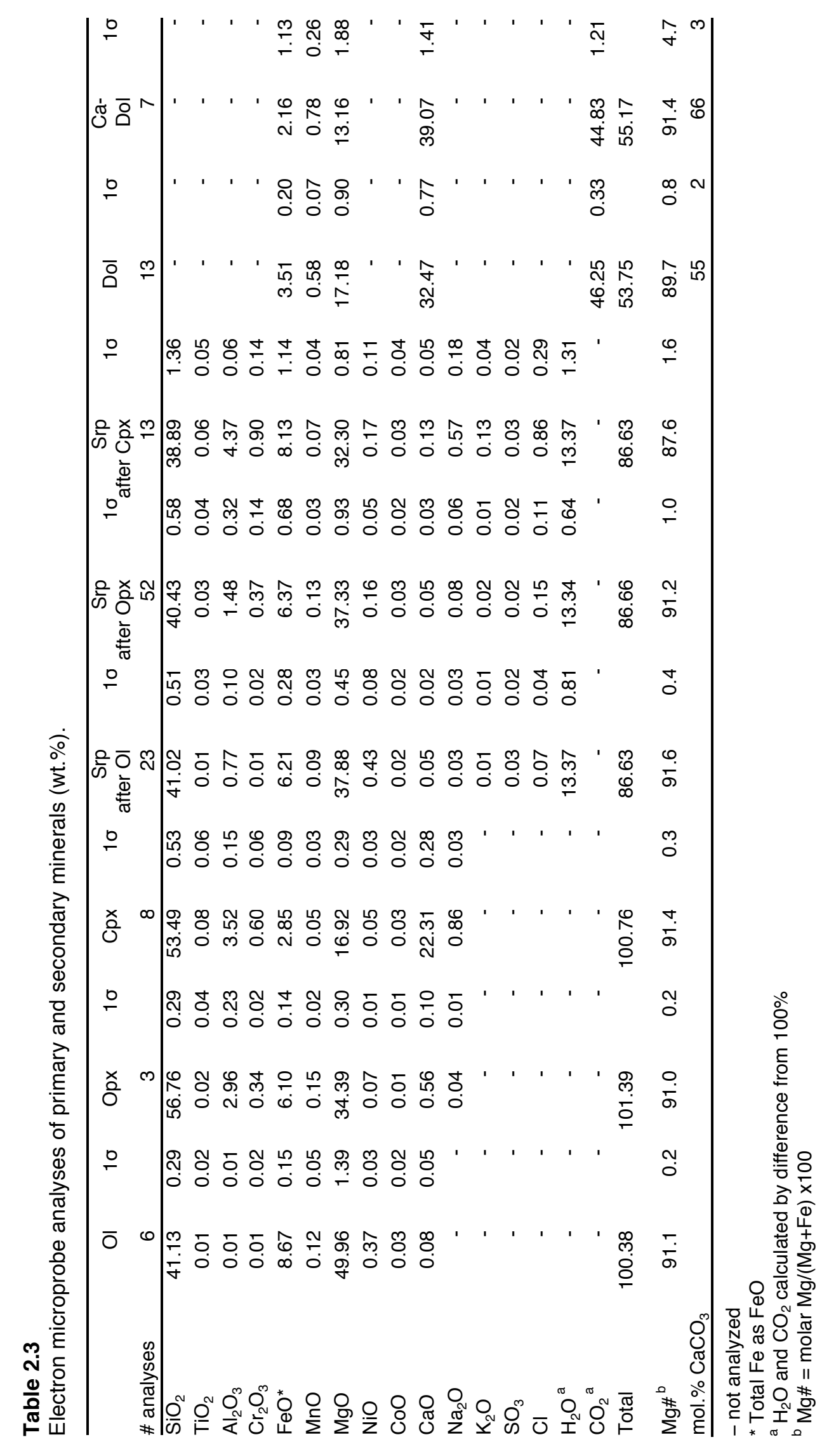


Table 2.4

Composition of harzburgite used in the reaction path model.

\begin{tabular}{lr}
\hline & wt.\% \\
\hline $\mathrm{SiO}_{2}$ & 45.52 \\
$\mathrm{Al}_{2} \mathrm{O}_{3}$ & 0.92 \\
$\mathrm{FeO}$ & 7.87 \\
$\mathrm{MgO}$ & 44.65 \\
$\mathrm{CaO}$ & 1.04 \\
\hline
\end{tabular}

Table 2.5

Composition of evolved seawater used in the reaction path model (mmol/kg).

\begin{tabular}{lr}
\hline $\mathrm{Na}$ & 463 \\
$\mathrm{~K}$ & 34.0 \\
$\mathrm{Ca}$ & 31 \\
$\mathrm{Mg}^{\mathrm{a}}$ & $10^{-6}$ \\
$\mathrm{Fe}^{\mathrm{a}}$ & $10^{-6}$ \\
$\mathrm{Al}^{\mathrm{a}}$ & $10^{-6}$ \\
$\mathrm{SiO}_{2}$ & 0.0001 \\
$\mathrm{O}_{2}{ }^{\mathrm{b}}$ & 0.16 \\
$\mathrm{Cl}$ & 553 \\
$\Sigma \mathrm{CO}_{2}$ & 0.06 \\
$\mathrm{pH}^{\mathrm{b}}$ & 5.65 \\
\hline
\end{tabular}

${ }^{\mathrm{a}} \mathrm{Mg}, \mathrm{Fe}$, and $\mathrm{Al}$ concentrations are assigned low values for speciation calculations.

${ }^{\mathrm{b}} \mathrm{O}_{2}$ and $\mathrm{pH}$ based on equilibrium with the atmosphere. 

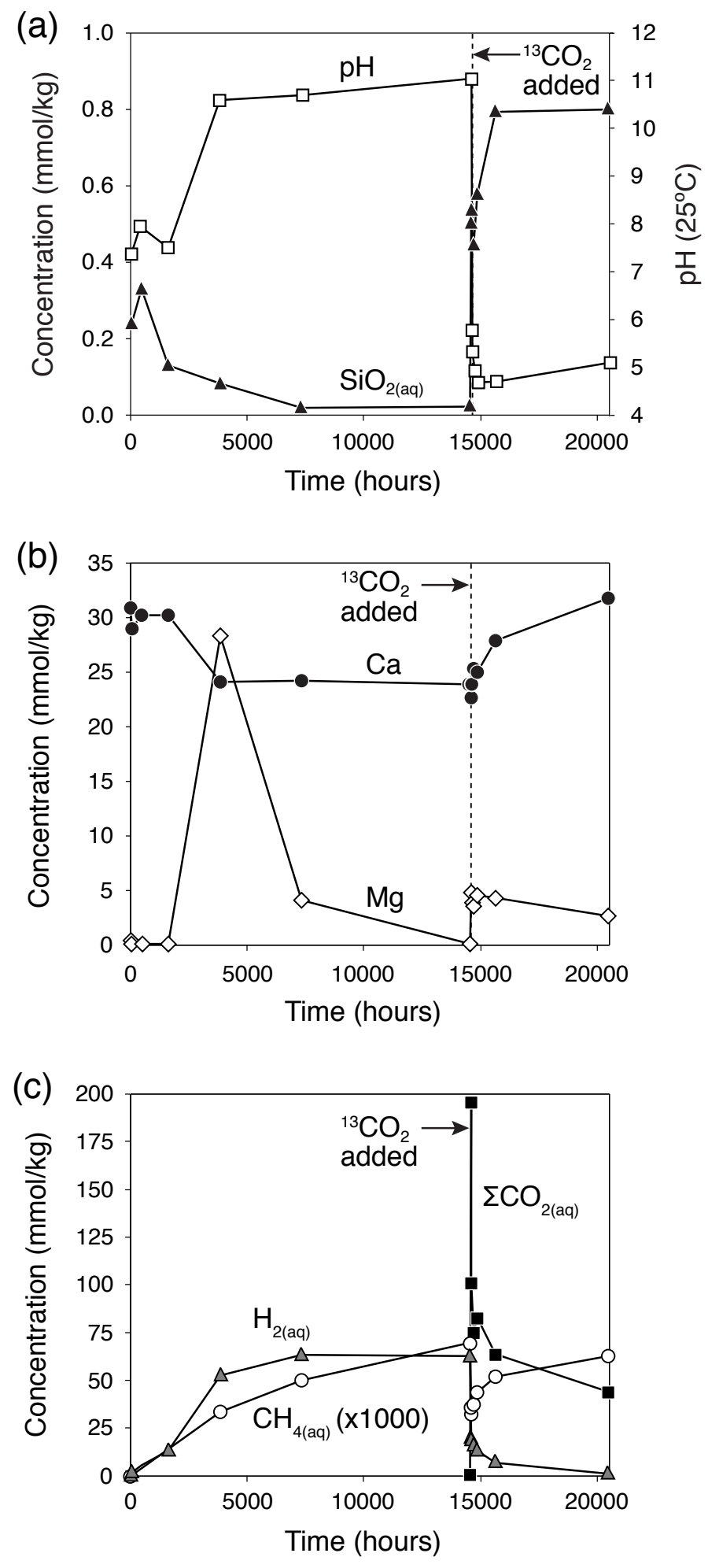

Figure 2.1

Changes in measured fluid chemistry as a function of time during serpentinization of harzburgite at $300^{\circ} \mathrm{C}$ and $35 \mathrm{MPa}$. (a) $\mathrm{pH}$ and $\mathrm{SiO}_{2(a q)}$, (b) dissolved $\mathrm{Ca}$ and $\mathrm{Mg}$, and (c) dissolved $\Sigma \mathrm{CO}_{2}, \mathrm{H}_{2}$, and $\mathrm{CH}_{4}$. 

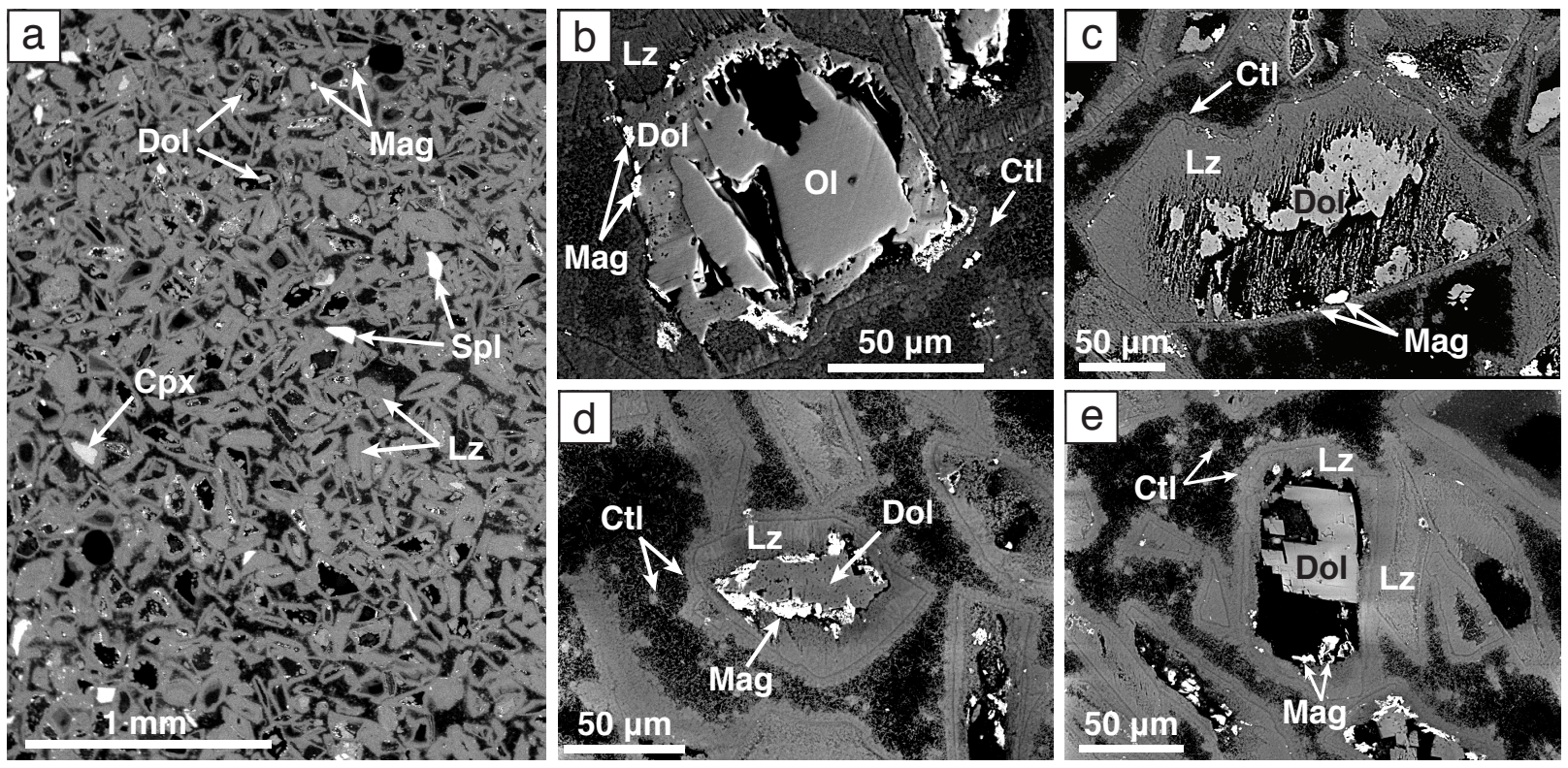

\section{Figure 2.2}

Backscattered electron (BSE) images of the solid reaction products. (a) Overview image showing lizardite and chrysotile overgrowing primary minerals (olivine, pyroxene, spinel) and cementing the harzburgite powder into a coherent, porous rock. (b) Relict olivine rimmed by a thin (10-20 $\mu \mathrm{m}$ wide) layer of dolomite, followed by a layer of lizardite. Note that anhedral magnetite formed at the interface between dolomite and lizardite. Olivine shows abundant embayments and etch pits resulting from dissolution. The saw-toothed nature of the reaction interface indicates that dolomite replaced olivine, most likely via a dissolution-precipitation reaction. (c-e) Primary silicates completely replaced by dolomite + lizardite \pm magnetite. Subhedral to euhedral dolomite occurs in the centers of replaced silicates and is rimmed by lizardite. Note again that anhedral magnetite occurs at the interface between dolomite and lizardite when formed at the expense of olivine. Chrysotile and magnetite rim the original primary mineral surfaces. Abbreviations: Cpx - clinopyroxene, Ctl - chrysotile, Dol - dolomite, Lz - lizardite, Mag magnetite, $\mathrm{Ol}$ - olivine, $\mathrm{Spl}$ - spinel 


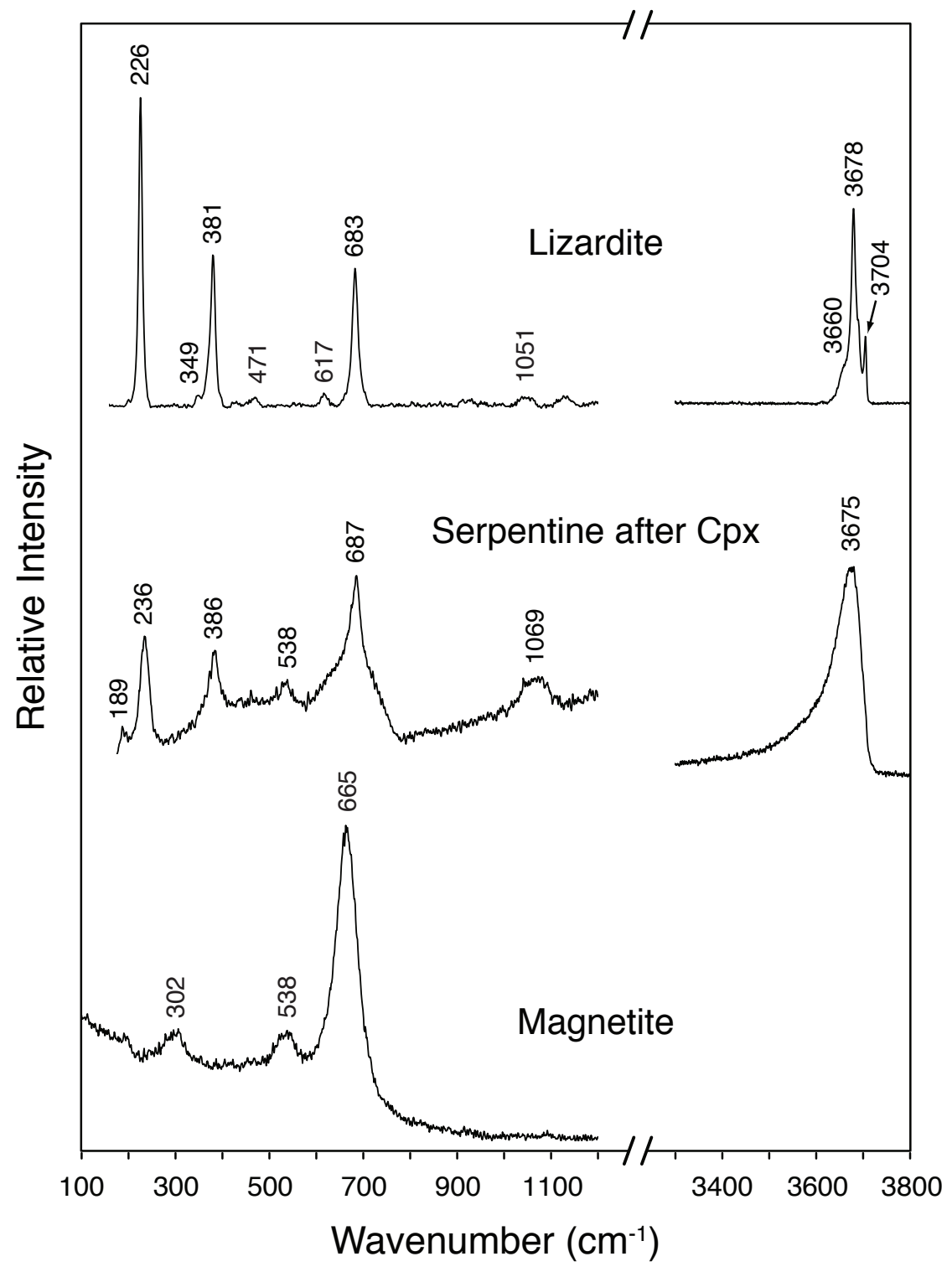

Figure 2.3

Representative Raman spectra of hydrous silicates and magnetite formed in the experiment. 


\section{Figure 2.4}

BSE images of primary and secondary minerals after 20499 hours of reaction. (a) Chrysotile fibers up to $20 \mu \mathrm{m}$ in length coated the original primary mineral surfaces and grew into the surrounding pore space. Chrysotile fibers were also observed to radiate outward from clusters within the pores. (b) A euhedral dolomite crystal on the surface of the powder surrounded by lizardite and fibrous chrysotile. (c) Euhedral to subhedral magnetite in the center of a completely serpentinized olivine. Chrysotile and magnetite rim the original mineral surface. (d) Compositional zonation observed in lizardite after orthopyroxene. Brighter regions near the rim correspond to $\mathrm{Fe}$ and $\mathrm{Al}$ enrichment in lizardite as revealed by electron microprobe analyses. (e) Alteration of primary clinopyroxene to serpentine minerals. Note the etch pits in clinopyroxene that indicate partial dissolution. (f) Magnified image of serpentine after clinopyroxene in e (dashed white box) showing the sheet-like or platy structure of the serpentine minerals. $(\mathrm{g})$ Unaltered spinel coated with chrysotile fibers. (h) Magnetite nucleated onto millerite. Because EDS and electron microprobe data show compositional homogeneity in millerite, the differences in brightness are likely due to surface imperfections of the platinum coating. Abbreviations: Chl - chlorite, Cpx - clinopyroxene, Ctl - chrysotile, Dol - dolomite, Lz - lizardite, Mag - magnetite, Mlr - millerite, Spl - spinel, Srp - serpentine 

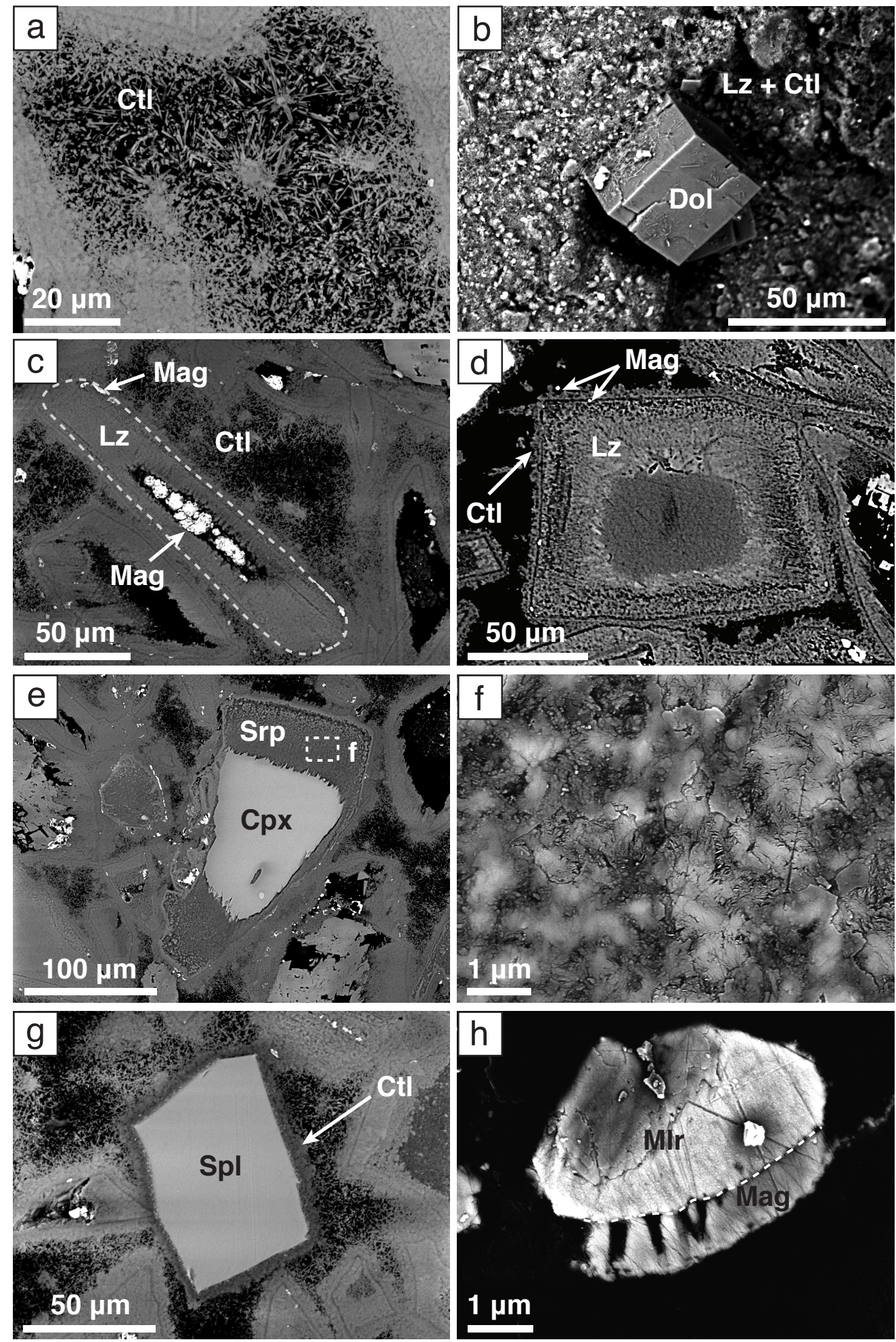

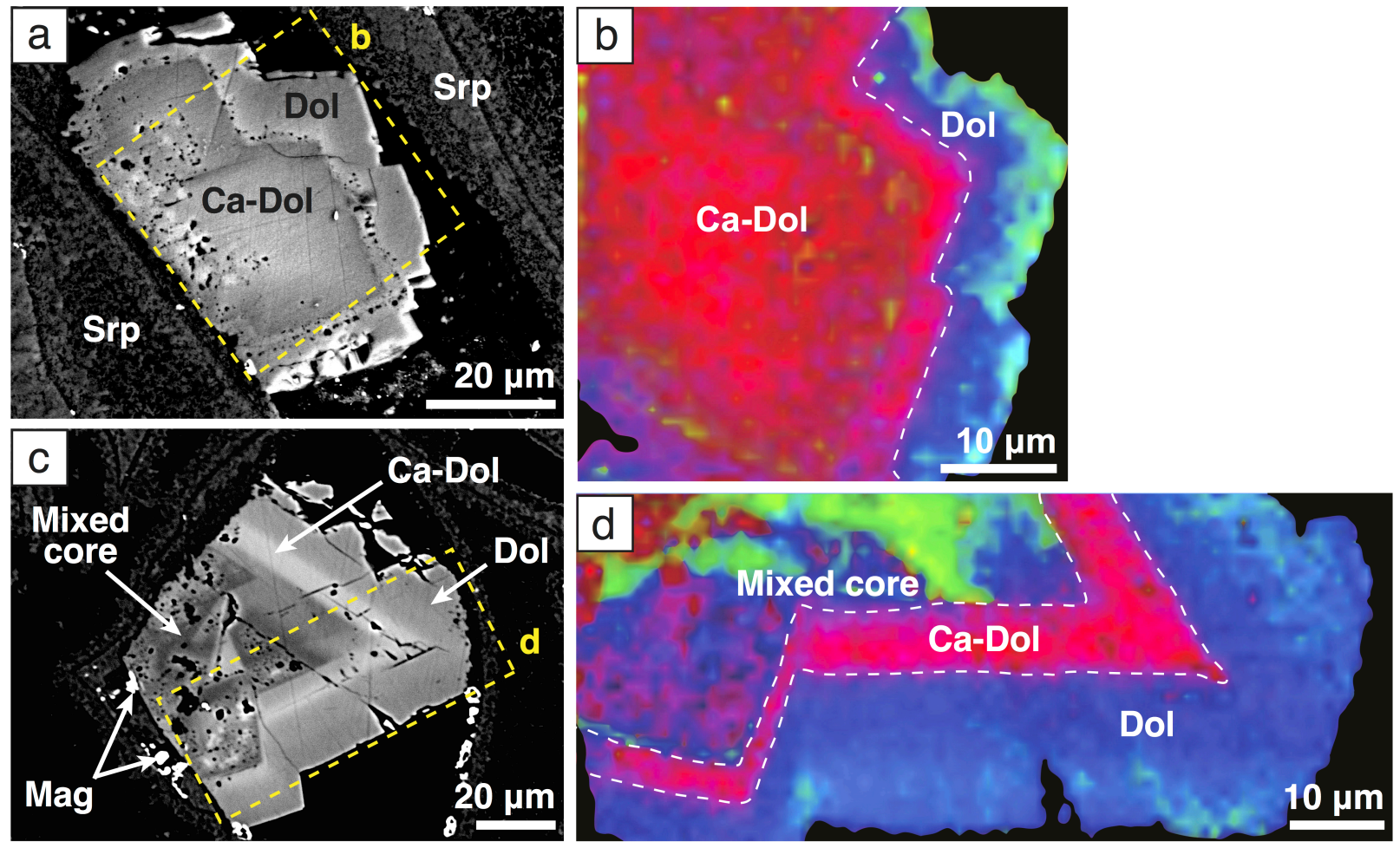

\section{Figure 2.5}

(a, c) BSE images of zoned carbonates containing distinct, rhombohedral layers. Dashed yellow boxes show areas mapped using confocal Raman spectroscopy. (a) Euhedral dolomite overgrew a porous $\mathrm{Ca}$-dolomite (Ca-Dol) containing approximately $64 \mathrm{~mol} . \% \mathrm{CaCO}_{3}$ as indicated by electron microprobe analysis. Although $\mathrm{Ca}$-dolomite is enriched in calcium, it appears as a dark core due to its relatively low $\mathrm{FeO}$ content (0.9-1.1 wt. \%) compared to that of dolomite (3.3 wt. \%). (c) Euhedral dolomite rimming a zone of Ca-rich dolomite and a dark, pitted core. Here, Ca-dolomite is brighter than that in (a) due to its higher FeO content (2.8 wt. \%). The core exhibits a mottled texture, suggesting a heterogeneous composition. (b, d) False-colored Raman maps showing changes in the frequency of the carbonate v1 internal mode. Colors represent average signal intensities in the following spectral regions: Red: $1087-1092 \mathrm{~cm}^{-1}$, Blue: 1092$1096 \mathrm{~cm}^{-1}$, Green: 1096-1100 $\mathrm{cm}^{-1}$. Both carbonates show a systematic shift toward lower band frequencies from rim to core, corresponding to more extensive Ca substitution into dolomite. The mixed core in (d) exhibits Raman peaks for Mg-calcite, Ca-dolomite, and Dolomite, while the core in (b) contains only Ca-dolomite. 


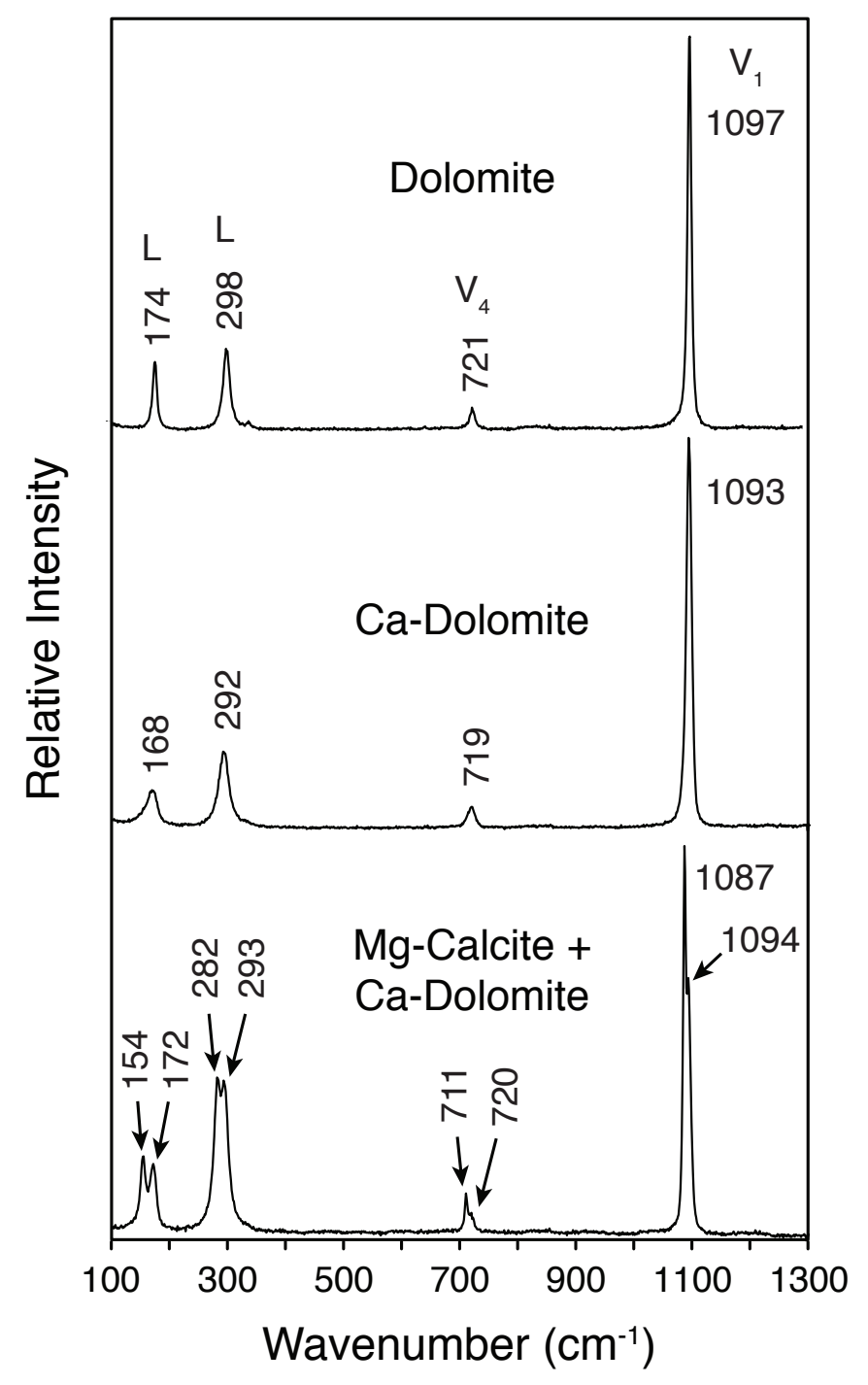

Figure 2.6

Raman spectra of dolomite, Ca-dolomite, and Mg-calcite, showing changes in band frequencies with composition. The carbonate internal modes (v1, v4) and two translational lattice modes (L) are systematically shifted to lower wavenumbers with increasing substitution of $\mathrm{Ca}$ into dolomite. 

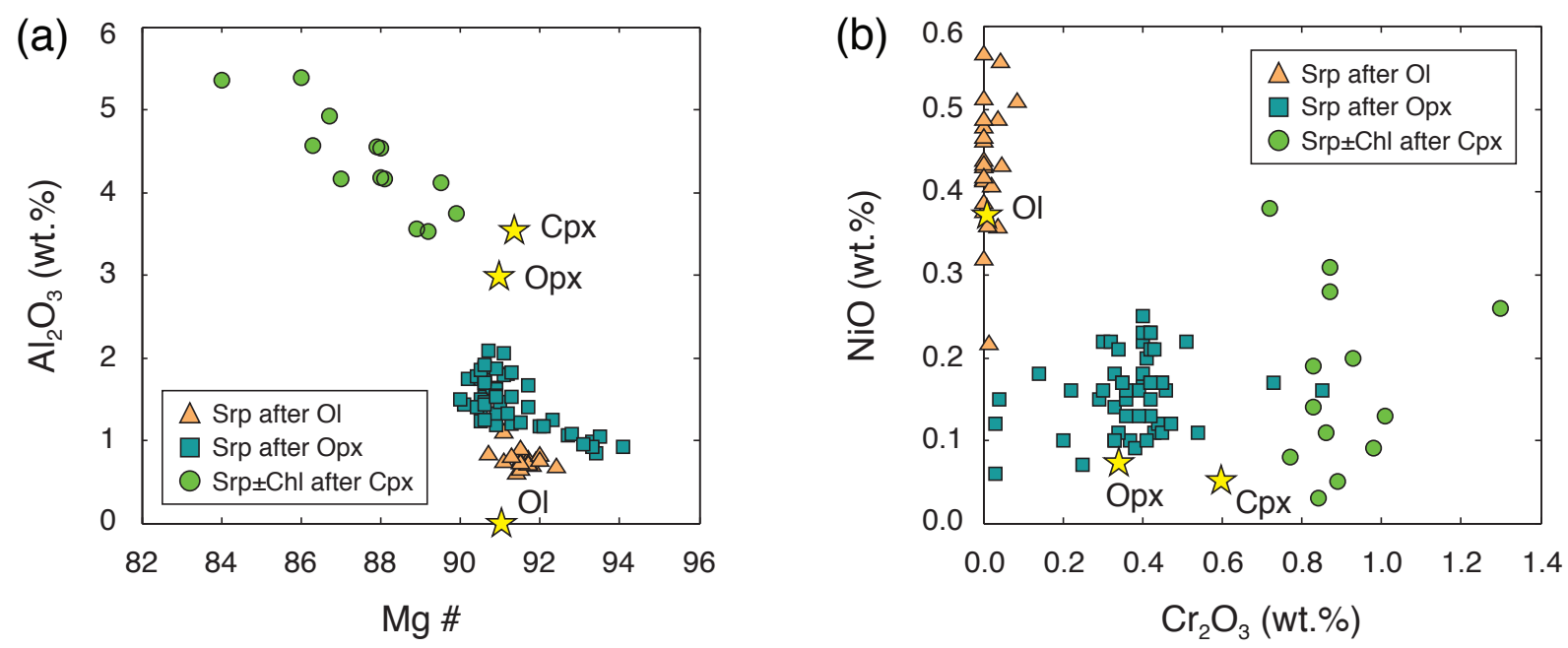

\section{Figure 2.7}

(a) Plot of $\mathrm{Al}_{2} \mathrm{O}_{3}$ content (wt. \%) vs. $\mathrm{Mg \#}$ of minerals replacing olivine, orthopyroxene, and clinopyroxene. Shown for comparison are the $\mathrm{Al}_{2} \mathrm{O}_{3}$ contents and $\mathrm{Mg \# s}$ of the primary silicates. Serpentine \pm chlorite after clinopyroxene is easily distinguishable by its high $\mathrm{Al}_{2} \mathrm{O}_{3}$ content $(>3.5$ wt. \%) and low Mg\# (<90). Serpentine after olivine and orthopyroxene have similar $\mathrm{Mg \# s,} \mathrm{with}$ averages of 91.6 and 91.2, respectively. However, they can be distinguished on the basis of $\mathrm{Al}_{2} \mathrm{O}_{3}$ contents, with serpentine after orthopyroxene containing more $\mathrm{Al}_{2} \mathrm{O}_{3}$ for a given $\mathrm{Mg \#}$ on average. (b) Plot of $\mathrm{NiO}$ vs. $\mathrm{Cr}_{2} \mathrm{O}_{3}$ content (wt. \%) of minerals replacing olivine, orthopyroxene, and clinopyroxene. Serpentine after olivine contains elevated $\mathrm{NiO}$ contents, while serpentine after pyroxene shows elevated $\mathrm{Cr}_{2} \mathrm{O}_{3}$ contents, reflecting compositional differences in the primary silicate precursors. 


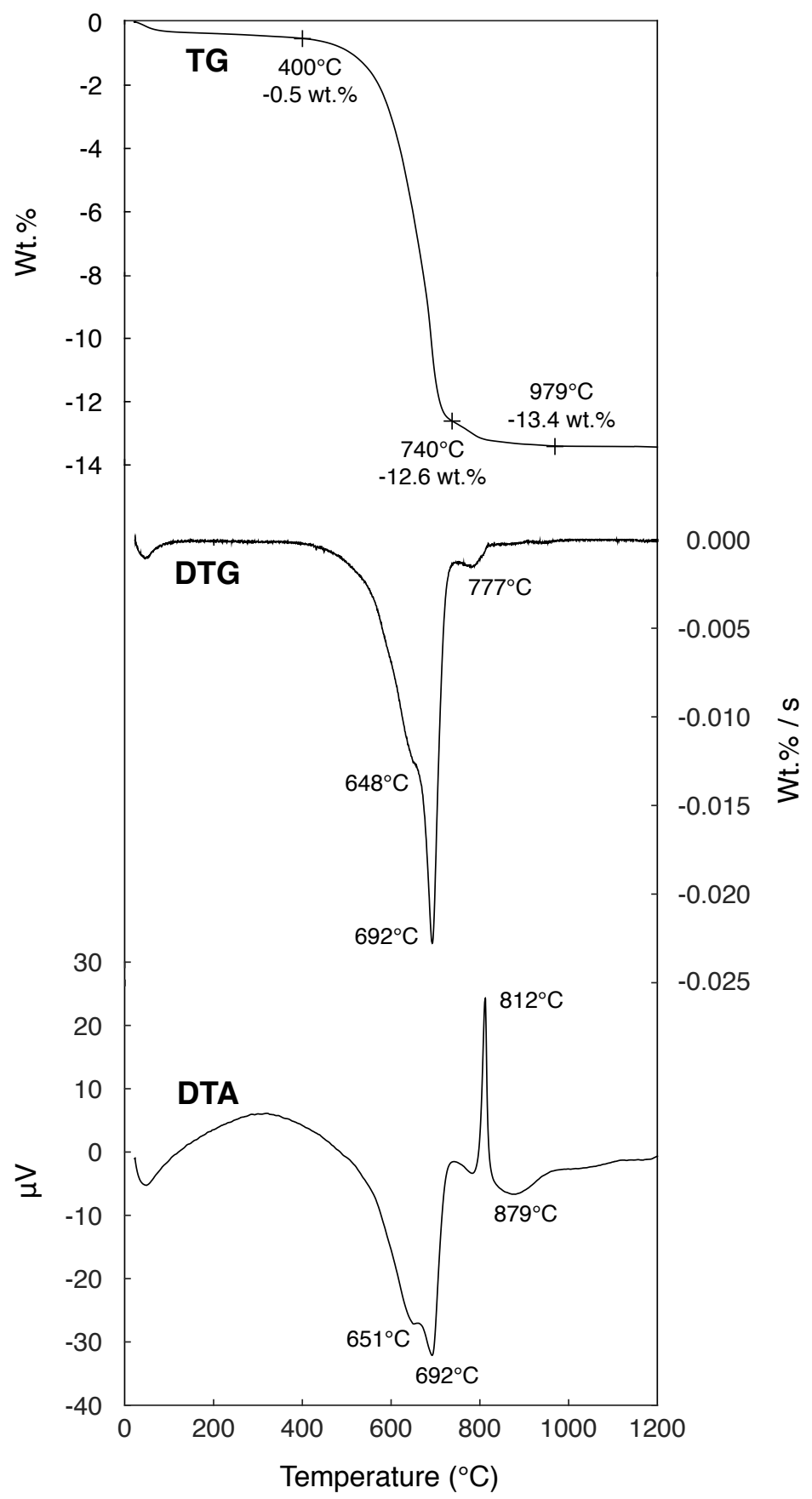

Figure 2.8.

Results from simultaneous thermogravimetric (TG) analysis and differential thermal analysis (DTA) of the solid products. Also shown is the derivative of the thermogravimetric curve (DTG). $39.7 \mathrm{mg}$ of solids were heated in air atmosphere at a rate of $10^{\circ} \mathrm{C} / \mathrm{min}$ from 20 to $1200^{\circ} \mathrm{C}$, resulting in a mass loss of $12.9 \mathrm{wt}$ \% due to devolatilization of serpentine and carbonate minerals. There is no indication of water loss due to breakdown of brucite. Minima in the DTA curve correspond to changes in heat flow resulting from desorption of adsorbed water or decomposition of discrete mineral phases. 


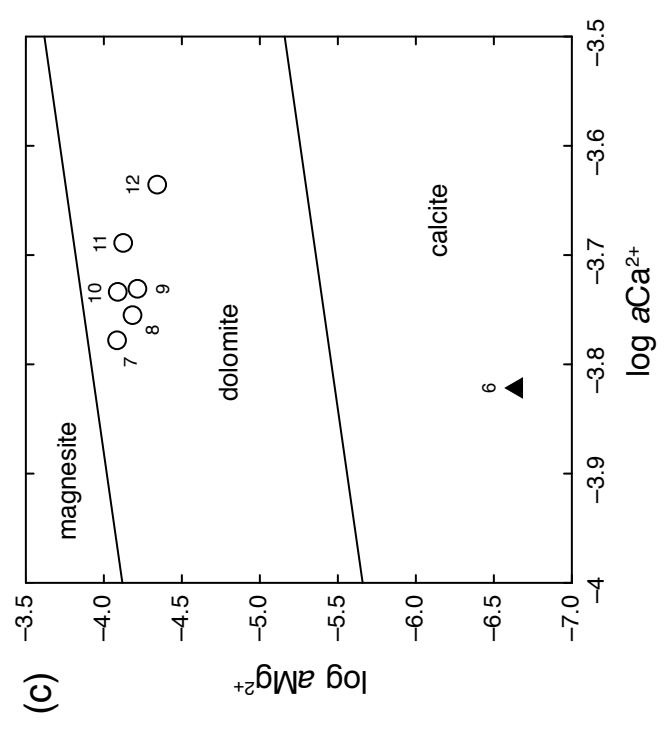

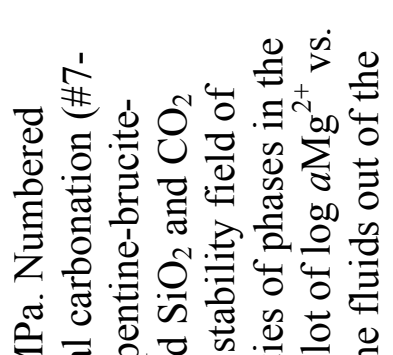

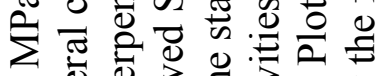

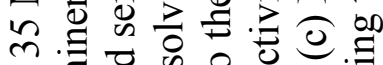

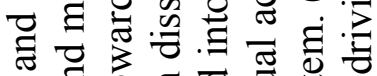

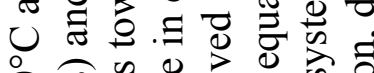

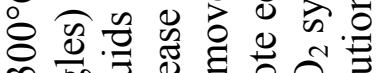

స

घ

ब

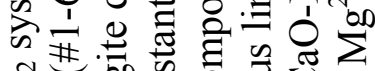

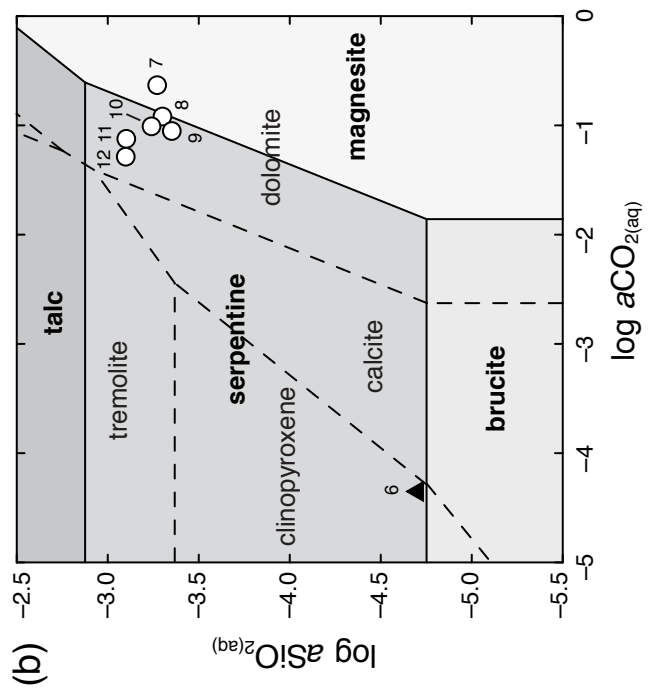

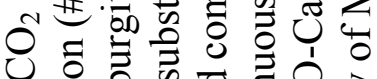

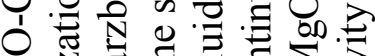

I. 글

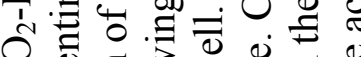

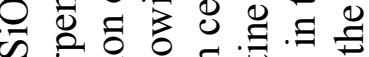

1

ల్ర

O.

$\sum_{0}$ 荡

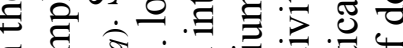

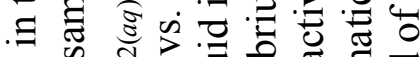

पै

.

牙

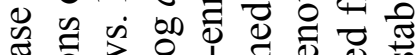

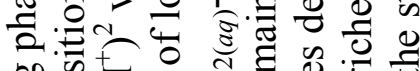

.00

.

웡

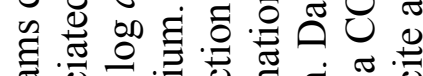

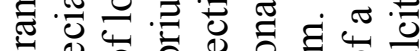
की 它䒕음

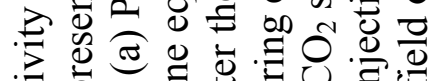

งิ

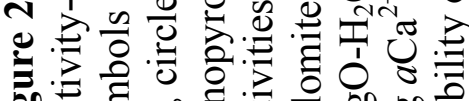

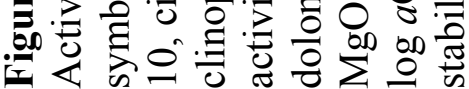



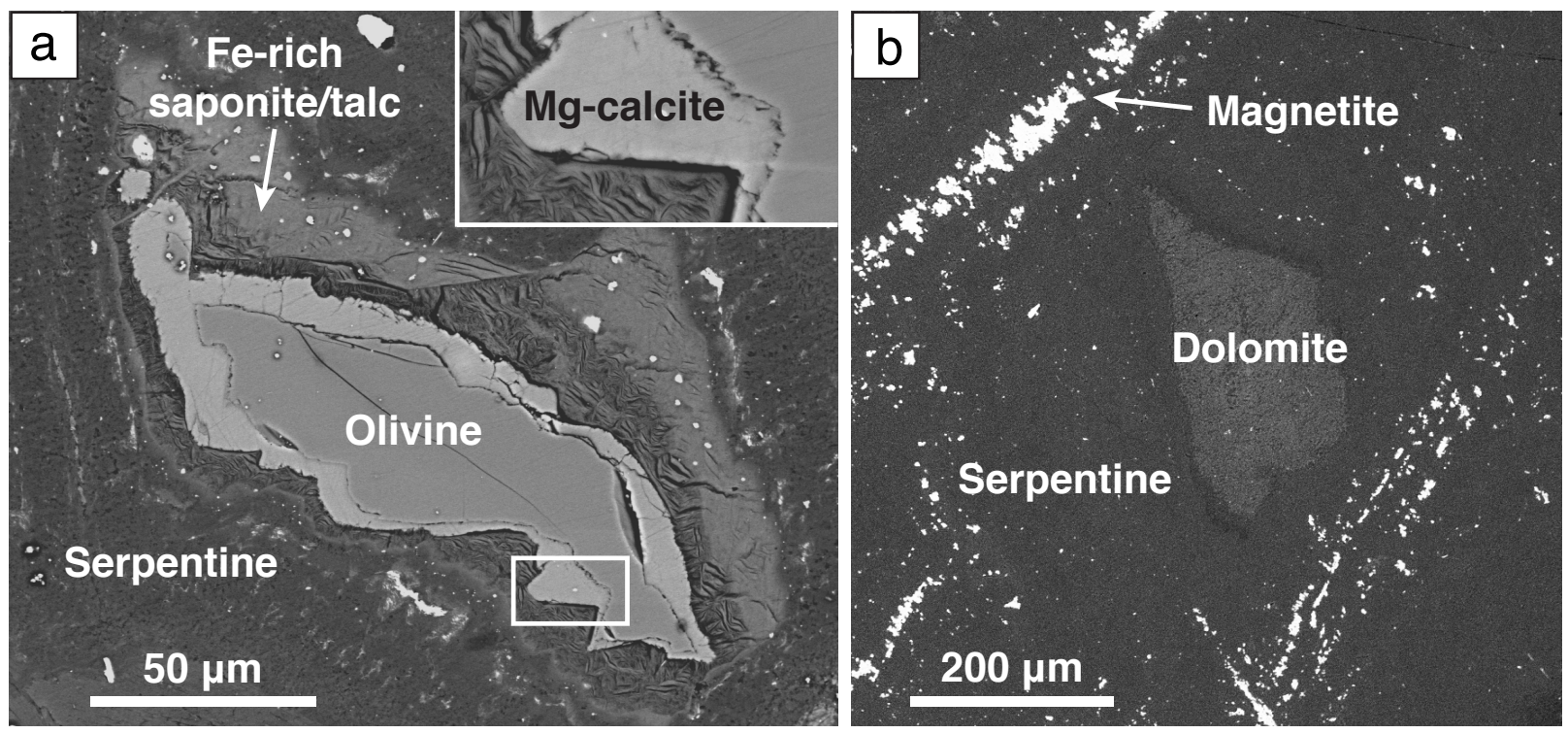

Figure 2.10

BSE images of carbonate-altered serpentinites from the Atlantis Massif, $30^{\circ} \mathrm{N}$ Mid-Atlantic Ridge (IODP Expedition 304). (a) High Mg-calcite forms a continuous rim over olivine. Note the saw-toothed nature of the reaction interface, which is similar to that formed between dolomite and relict olivine in the experiment. (Reprinted with permission from Andreani et al., 2009. Copyright 2015 American Chemical Society) (b) Dolomite replaces the center of a serpentine mesh compartment. 


\section{Figure 2.11}

Reaction path model simulating the serpentinization and subsequent carbonation of harzburgite at $300^{\circ} \mathrm{C}$ and $50 \mathrm{MPa}$. Increasing reaction progress reflects the incremental addition of rock to fluid in a closed system, resulting in a decrease in the fluid-to-rock mass ratio (F/R). The addition of the $\mathrm{CO}_{2}$-rich fluid at a reaction progress of 1 causes a sharp increase in $\mathrm{F} / \mathrm{R}$. Thermodynamic equilibrium is attained at each step of the reaction. (a) Calculated changes in mineral proportions during serpentinization and carbonation. Serpentine, brucite, clinopyroxene, magnetite, and chlorite are predicted to form a stable mineral assemblage upon complete serpentinization of harzburgite, consistent with petrographic observations and fluid speciation calculations in the experiment. Garnet is also predicted to have formed, but was not observed among the reaction products. Subsequent addition of a $\mathrm{CO}_{2(a q)}$-rich fluid causes brucite, clinopyroxene, and magnetite to dissolve in favor of dolomite and magnesite. Additional minerals predicted to form after the injection include graphite, talc, and saponite. (b) Calculated changes in fluid chemistry during serpentinization and subsequent carbonation of harzburgite. (c) and (d) are enlarged portions of (a) and (b), respectively, showing calculated changes in mineral proportions and fluid chemistry during the incipient stages of carbonation. The model predicts that dolomite forms first when the $\mathrm{Mg} / \mathrm{Ca}$ ratio of the fluid is low $(<0.2)$. Magnesite is not predicted to form until sufficient dissolved $\mathrm{Ca}$ is consumed and $\mathrm{Mg}$ is released into solution. Abbreviations: Brc - brucite, Chl - chlorite, Cpx - clinopyroxene, Dol - dolomite, Gr - graphite, Grt - garnet, Mag - magnetite, Mgs - magnesite, Sap - saponite, Srp - serpentine, Tlc - talc 
(a)

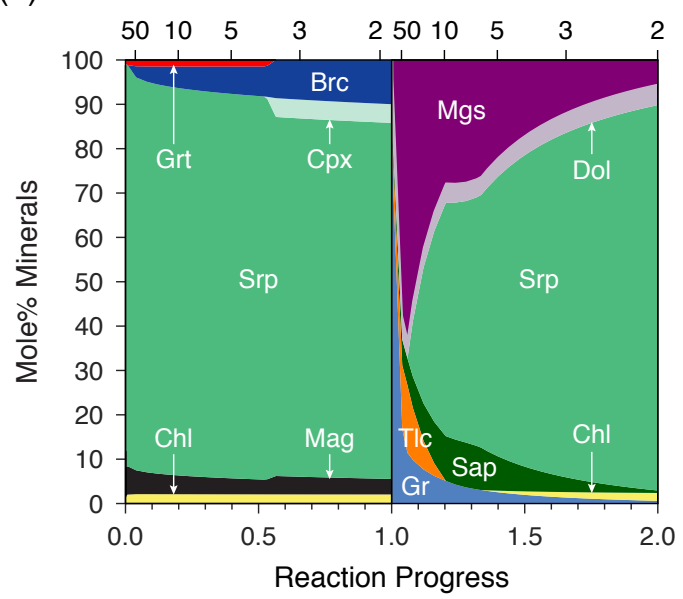

(c)

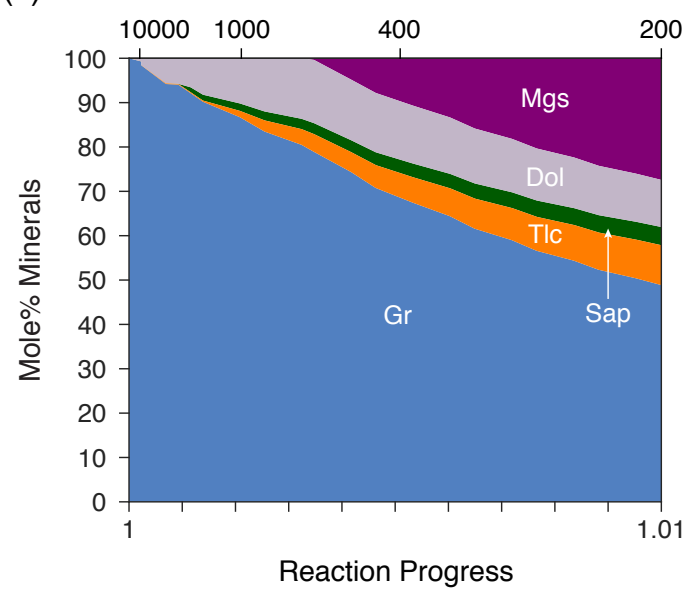

(b)

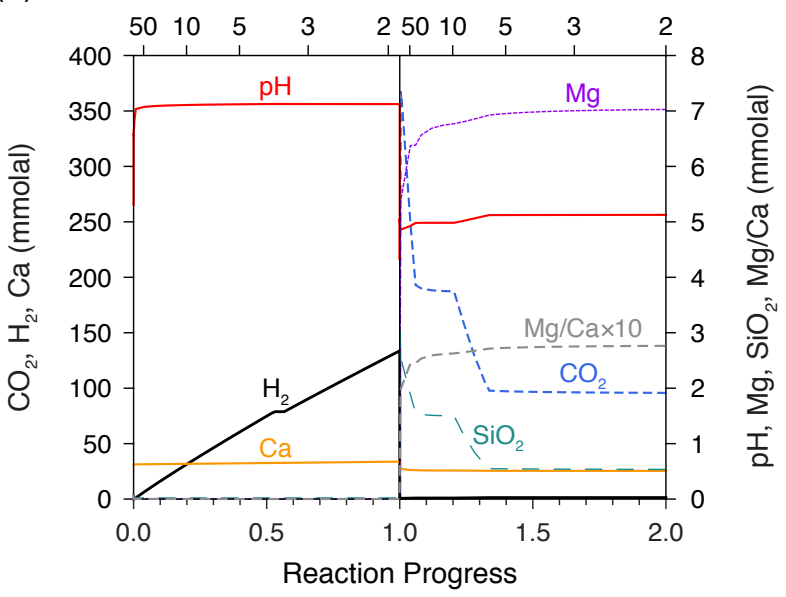

(d)

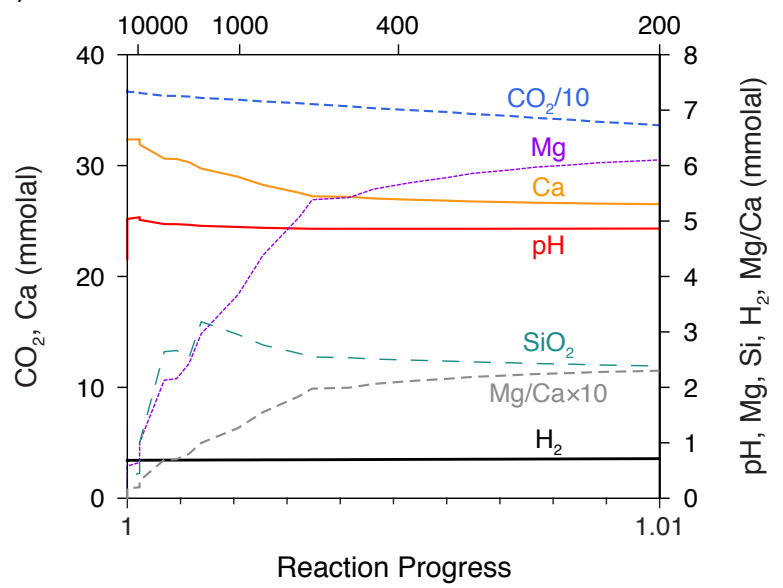




\section{REFERENCES}

Allen D. E. and Seyfried W. E. Jr (2003) Compositional controls on vent fluids from ultramafichosted hydrothermal systems at mid-ocean ridges: An experimental study at $400^{\circ} \mathrm{C}, 500$ bars. Geochim. Cosmochim. Acta 67, 1531-1542.

Alt J. C. and Shanks W. C. III (1998) Sulfur in serpentinized oceanic peridotites: Serpentinization processes and microbial sulfate reduction. J. Geophys. Res. 103, $9917-$ 9929.

Andreani M., Luquot L., Gouze P., Godard M., Hoisé E. and Gibert B. (2009) Experimental study of carbon sequestration reactions controlled by the percolation of $\mathrm{CO}_{2}$-rich brine through peridotites. Environ. Sci. Technol. 43, 1226-1231.

Andreani M., Muñoz M., Marcaillou C. and Delacour A. (2013) $\mu$ XANES study of iron redox state in serpentine during oceanic serpentinization. Lithos 178, 70-83.

Arvidson R. S. and Mackenzie F. T. (1997) Tentative kinetic model for dolomite precipitation rate and its application to dolomite distribution. Aquat. Geochemistry 2, 273-298.

Bach W., Rosner M., Jöns N., Rausch S., Robinson L. F., Paulick H. and Erzinger J. (2011) Carbonate veins trace seawater circulation during exhumation and uplift of mantle rock: Results from ODP Leg 209. Earth Planet. Sci. Lett. 311, 242-252.

Bach W., Klein F. and Jöns N. (2013) Metasomatism within the ocean crust. In Metasomatism and the Chemical Transformation of Rock (eds. D. E. Harlov and H. Austrheim). Springer Berlin Heidelberg. pp. 253-288.

Barnes I. and O'Neil J. R. (1969) The relationship between fluids in some fresh alpine-type ultramafics and possible modern serpentinization, Western United States. Geol. Soc. Am. Bull. 80, 1947-1960.

Barnes I., O'Neil J. R., Rapp J. B. and White D. E. (1973) Silica-carbonate alteration of serpentine: Wall rock alteration in mercury deposits of the California Coast Ranges. Econ. Geol. 68, 388-398.

Beard J. S. and Hopkinson L. (2000) A fossil, serpentinization-related hydrothermal vent, Ocean Drilling Program Leg 173, Site 1068 (Iberia Abyssal Plain): Some aspects of mineral and fluid chemistry. J. Geophys. Res. 105, 16527-16539.

Beinlich A., Plümper O., Hövelmann J., Austrheim H. and Jamtveit B. (2012) Massive serpentinite carbonation at Linnajavri, N-Norway. Terra Nov. 24, 446-455.

Berndt M. E., Seyfried W. E. Jr and Janecky D. R. (1989) Plagioclase and epidote buffering of cation ratios in mid-ocean ridge hydrothermal fluids: Experimental results in and near the supercritical region. Geochim. Cosmochim. Acta 53, 2283-2300.

Berndt M. E., Allen D. E. and Seyfried W. E. Jr (1996) Reduction of $\mathrm{CO}_{2}$ during serpentinization of olivine at $300^{\circ} \mathrm{C}$ and 500 bar. Geology 24, 351-354.

Bischoff J. L. and Dickson F. W. (1975) Seawater-basalt interaction at $200^{\circ} \mathrm{C}$ and 500 bars: Implications for origin of sea-floor heavy-metal deposits and regulation of seawater chemistry. Earth Planet. Sci. Lett. 25, 385-397.

Bodinier J.-L. and Godard M. (2003) Orogenic, ophiolitic, and abyssal peridotites. In Treatise on Geochemistry, vol. 2, The Mantle and Core (eds. R. W. Carlson, H. D. Holland, and K. K. Turekian). Elsevier, New York. pp. 103-170.

Böhlke J. K. (1989) Comparison of metasomatic reactions between a common $\mathrm{CO}_{2}$-rich vein fluid and diverse wall rocks: Intensive variables, mass transfers, and Au mineralization at Alleghany, California. Econ. Geol. 84, 291-327. 
Bonatti E., Emiliani C., Ferrara G., Honnorez J. and Rydell H. (1974) Ultramafic-carbonate breccias from the equatorial Mid Atlantic Ridge. Mar. Geol. 16, 83-102.

Boschi C., Dini A., Dallai L., Ruggieri G. and Gianelli G. (2009) Enhanced $\mathrm{CO}_{2}$-mineral sequestration by cyclic hydraulic fracturing and Si-rich fluid infiltration into serpentinites at Malentrata (Tuscany, Italy). Chem. Geol. 265, 209-226.

Bruni J., Canepa M., Chiodini G., Cioni R., Cipolli F., Longinelli A., Marini L., Ottonello G. and Zuccolini M. V. (2002) Irreversible water-rock mass transfer accompanying the generation of the neutral, $\mathrm{Mg}-\mathrm{HCO}_{3}$ and high-pH, $\mathrm{Ca}-\mathrm{OH}$ spring waters of the Genova province, Italy. Appl. Geochem. 17, 455-474.

Cannat M., Fontaine F. and Escartín J. (2010) Serpentinization and associated hydrogen and methane fluxes at slow spreading ridges. In Diversity of Hydrothermal Systems on Slow Spreading Ocean Ridges (eds. P. A. Rona, C. W. Devey, J. D. And, and B. J. Murton). American Geophysical Union, Washington, D. C. pp. 241-264.

Carlson R. L. (2001) The abundance of ultramafic rocks in Atlantic Ocean crust. Geophys. J. Int. 144, 37-48.

Cipolli F., Gambardella B., Marini L., Ottonello G. and Zuccolini M. V. (2004) Geochemistry of high-pH waters from serpentinites of the Gruppo di Voltri (Genova, Italy) and reaction path modeling of $\mathrm{CO}_{2}$ sequestration in serpentinite aquifers. Appl. Geochem. 19, 787-802.

Cody G., Boctor N., Brandes J., Filley T., Hazen R. and Yoder H. (2004) Assaying the catalytic potential of transition metal sulfides for abiotic carbon fixation. Geochim. Cosmochim. Acta 68, 2185-2196.

Dabitzias S. G. (1980) Petrology and genesis of the Vavdos cryptocrystalline magnesite deposits, Chalkidiki Peninsula, northern Greece. Econ. Geol. 75, 1138-1151.

Daval D., Hellmann R., Martinez I., Gangloff S. and Guyot F. (2013) Lizardite serpentine dissolution kinetics as a function of $\mathrm{pH}$ and temperature, including effects of elevated $p \mathrm{CO}_{2}$. Chem. Geol. 351, 245-256.

del Real P. G., Maher K., Kluge T., Bird D. K., Brown G. E. Jr and John C. M. (2016) Clumpedisotope thermometry of magnesium carbonates in ultramafic rocks. Geochim. Cosmochim. Acta, doi: http://dx.doi.org/10.1016/j.gca.2016.08.003.

Des Marais D. J. and Moore J. G. (1984) Carbon and its isotopes in mid-oceanic basaltic glasses. Earth Planet. Sci. Lett. 69, 43-57.

Dick H. J. B., Lin J. and Schouten H. (2003) An ultraslow-spreading class of ocean ridge. Nature 426, 405-412.

Douville E., Charlou J. L., Oelkers E. H., Bienvenu P., Jove Colon C. F., Donval J. P., Fouquet Y., Prieur D. and Appriou P. (2002) The Rainbow vent fluids (36² $\left.14^{\prime} \mathrm{N}, \mathrm{MAR}\right)$ : The influence of ultramafic rocks and phase separation on trace metal content in Mid-Atlantic Ridge hydrothermal fluids. Chem. Geol. 184, 37-48.

Eckstrand O. R. (1975) The Dumont serpentinite: A model for control of nickel-iferous opaque mineral assemblages by alteration reations in ultramafic rocks. Econ. Geol. 70, 183-201.

Eickmann B., Bach W. and Peckmann J. (2009) Authigenesis of carbonate minerals in modern and Devonian ocean-floor hard rocks. J. Geol. 117, 307-323.

Falk E. S. and Kelemen P. B. (2015) Geochemistry and petrology of listvenite in the Samail ophiolite, Sultanate of Oman: Complete carbonation of peridotite during ophiolite emplacement. Geochim. Cosmochim. Acta 160, 70-90.

Foustoukos D. I. and Seyfried W. E. Jr (2004) Hydrocarbons in hydrothermal vent fluids: The role of chromium-bearing catalysts. Science 304, 1002-1005. 
Frost B. R. (1985) On the stability of sulfides, oxides, and native metals in serpentinite. J. Petrol. 26, 31-63.

Fryer P., Mottl M., Johnson L., Haggerty J., Phipps S. and Maekawa H. (1995) Serpentine bodies in the forearcs of western Pacific convergent margins: Origin and associated fluids. In Active Margins and Marginal Basins of the Western Pacific (eds. B. Taylor and J. Natland). American Geophysical Union, Washington, D. C. pp. 259-279.

Fu Q., Sherwood Lollar B., Horita J., Lacrampe-Couloume G. and Seyfried W. E. Jr (2007) Abiotic formation of hydrocarbons under hydrothermal conditions: Constraints from chemical and isotope data. Geochim. Cosmochim. Acta 71, 1982-1998.

Fu Q., Foustoukos D. I. and Seyfried W. E. Jr (2008) Mineral catalyzed organic synthesis in hydrothermal systems: An experimental study using time-of-flight secondary ion mass spectrometry. Geophys. Res. Lett. 35, L07612, doi:10.1029/2008GL033389.

Gablina I. F., Semkova T. A., Stepanova T. V. and Gor'kova N. V. (2006) Diagenetic alterations of copper sulfides in modern ore-bearing sediments of the Logatchev-1 hydrothermal field

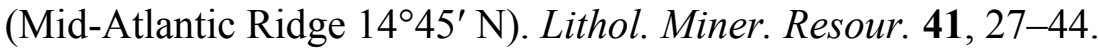

Gamo T., Chiba H., Yamanaka T., Okudaira T., Hashimoto J., Tsuchida S., Ishibashi J., Kataoka S., Tsunogai U., Okamura K., Sano Y. and Shinjo R. (2001) Chemical characteristics of newly discovered black smoker fluids and associated hydrothermal plumes at the Rodriguez Triple Junction, Central Indian Ridge. Earth Planet. Sci. Lett. 193, 371-379.

Gerdemann S. J., O’Connor W. K., Dahlin D. C., Penner L. R. and Rush H. (2007) Ex situ aqueous mineral carbonation. Environ. Sci. Technol. 41, 2587-2593.

Gerlach T. M. (1989) Degassing of carbon dioxide from basaltic magma at spreading centers: II. Mid-oceanic ridge basalts. J. Volcanol. Geotherm. Res. 39, 221-232.

Giammar D. E., Bruant R. G. and Peters C. A. (2005) Forsterite dissolution and magnesite precipitation at conditions relevant for deep saline aquifer storage and sequestration of carbon dioxide. Chem Geol. 217, 257-276.

Gole M. J., Barnes S. J. and Hill R. E. T. (1987) The role of fluids in the metamorphism of komatiites, Agnew nickel deposit, western Australia. Contrib. Mineral. Petrol. 96, 151-162.

Griffis R. (1972) Genesis of a magnesite deposit, Deloro Twp., Ontario. Econ. Geol. 67, 63-71.

Groves D. I., Hudson D. R. and Hack T. B. C. (1974) Modification of iron-nickel sulfides during serpentinization and talc-carbonate alteration at Black Swan, Western Australia. Econ. Geol. 69, 1265-1281.

Hanor J. S. and Duchač K. C. (1990) Isovolumetric silicification of early Archean komatiites: Geochemical mass balances and constraints on origin. J. Geol. 98, 863-877.

Hansen L. D., Dipple G. M., Gordon T. M. and Kellett D. A. (2005) Carbonated serpentinite (listwanite) at Atlin, British Columbia: A geological analogue to carbon dioxide sequestration. Can. Mineral. 43, 225-239.

Harrison A. L., Power I. M. and Dipple G. M. (2013) Accelerated carbonation of brucite in mine tailings for carbon sequestration. Environ. Sci. Technol. 47, 126-134.

Hövelmann J., Austrheim H., Beinlich A. and Munz I. A. (2011) Experimental study of the carbonation of partially serpentinized and weathered peridotites. Geochim. Cosmochim. Acta 75, 6760-6779.

Johnson J. W., Oelkers E. H. and Helgeson H. C. (1992) SUPCRT92: A software package for calculating the standard molal thermodynamic properties of minerals, gases, aqueous species, and reactions from 1 to 5000 bar and 0 to $1000^{\circ} \mathrm{C}$. Comput. Geosci. 18, 899-947.

Jonas L., Müller T., Dohmen R., Baumgartner L. and Putlitz B. (2015) Transport-controlled 
hydrothermal replacement of calcite by Mg-carbonates. Geology 43, 779-782.

Jones L. C., Rosenbauer R., Goldsmith J. I. and Oze C. (2010) Carbonate control of $\mathrm{H}_{2}$ and $\mathrm{CH}_{4}$ production in serpentinization systems at elevated P-Ts. Geophys. Res. Lett. 37, L14306, doi:10.1029/2010GL043769.

Kaczmarek S. E. and Sibley D. F. (2014) Direct physical evidence of dolomite recrystallization. Sedimentology 61, 1862-1882.

Kahl W.-A., Jöns N., Bach W., Klein F. and Alt J. C. (2015) Ultramafic clasts from the South Chamorro serpentine mud volcano reveal a polyphase serpentinization history of the Mariana forearc mantle. Lithos 227, 1-20.

Katz A. and Matthews A. (1977) The dolomitization of $\mathrm{CaCO}_{3}$ : An experimental study at 252$295^{\circ}$ C. Geochim. Cosmochim. Acta 41, 297-308.

Kelemen P. B. and Matter J. M. (2008) In situ carbonation of peridotite for $\mathrm{CO}_{2}$ storage. Proc. Natl. Acad. Sci. 105, 17295-17300.

Kelemen P. B., Kikawa E., Miller D. J., Abe N., Bach W., Carlson R. L., Casey J. F., Chambers L. M., Cheadle M., Cipriani A., Dick H. J. B., Faul U., Garces M., Garrido C., Gee J. S., Godard M. M., Graham D. W., Griffin D. W., Harvey J., Ildefonse B., Iturrino G. J., Josef J., Meurer W. P., Paulick H., Rosner M., Schroeder T., Seyler M. and Takazawa E. (2004) Site 1275. Proc. Ocean Drill. Program, Initial Reports 209, 1-167. College Station, TX (Ocean Drilling Program). doi:10.2973/odp.proc.ir.209.110.2004.

Kelemen P. B., Matter J., Streit E. E., Rudge J. F., Curry W. B. and Blusztajn J. (2011) Rates and mechanisms of mineral carbonation in peridotite: Natural processes and recipes for enhanced, in situ $\mathrm{CO}_{2}$ capture and storage. Annu. Rev. Earth Planet. Sci. 39, 545-576.

Kelley D. S., Karson J. A., Früh-Green G. L., Yoerger D. R., Shank T. M., Butterfield D. A., Hayes J. M., Schrenk M. O., Olson E. J., Proskurowski G., Jakuba M., Bradley A., Larson B., Ludwig K., Glickson D., Buckman K., Bradley A. S., Brazelton W. J., Roe K., Bernasconi S. M., Elend M. J., Lilley M. D., Baross J. A., Summons R. E. and Sylva S. P. (2005) A serpentinite-hosted ecosystem: The Lost City hydrothermal field. Science 307, $1428-1434$.

King H. E., Plümper O. and Putnis A. (2010) Effect of secondary phase formation on the carbonation of olivine. Environ. Sci. Technol. 44, 6503-6509.

King H. E., Satoh H., Tsukamoto K. and Putnis A. (2014) Surface-specific measurements of olivine dissolution by phase-shift interferometry. Am. Mineral. 99, 377-386.

Klein F. and Bach W. (2009) Fe-Ni-Co-O-S phase relations in peridotite-seawater interactions. $J$. Petrol. 50, 37-59.

Klein F. and Garrido C. J. (2011) Thermodynamic constraints on mineral carbonation of serpentinized peridotite. Lithos 126, 147-160.

Klein F. and McCollom T. M. (2013) From serpentinization to carbonation: New insights from a $\mathrm{CO}_{2}$ injection experiment. Earth Planet. Sci. Lett. 379, 137-145.

Klein F., Bach W., Jöns N., McCollom T., Moskowitz B. and Berquó T. (2009) Iron partitioning and hydrogen generation during serpentinization of abyssal peridotites from $15^{\circ} \mathrm{N}$ on the Mid-Atlantic Ridge. Geochim. Cosmochim. Acta 73, 6868-6893.

Klein F., Bach W. and McCollom T. M. (2013) Compositional controls on hydrogen generation during serpentinization of ultramafic rocks. Lithos 178, 55-69.

Klein F., Bach W., Humphris S. E., Kahl W.-A., Jöns N., Moskowitz B. and Berquó T. S. (2014) Magnetite in seafloor serpentinite - Some like it hot. Geology 42, 135-138.

Klein F., Grozeva N. G., Seewald J. S., McCollom T. M., Humphris S. E., Moskowitz B., 
Berquó T. S. and Kahl W.-A. (2015a) Experimental constraints on fluid-rock reactions during incipient serpentinization of harzburgite. Am. Mineral. 100, 991-1002.

Klein F., Humphris S. E., Guo W., Schubotz F., Schwarzenbach E. M. and Orsi W. D. (2015b) Fluid mixing and the deep biosphere of a fossil Lost City-type hydrothermal system at the Iberia Margin. Proc. Natl. Acad. Sci. 112, 12036-12041.

Lafay R., Montes-Hernandez G., Janots E., Chiriac R., Findling N. and Toche F. (2014) Simultaneous precipitation of magnesite and lizardite from hydrothermal alteration of olivine under high-carbonate alkalinity. Chem. Geol. 368, 63-75.

Lilley M. D., Butterfield D. A., Lupton J. E. and Olson E. J. (2003) Magmatic events can produce rapid changes in hydrothermal vent chemistry. Nature 422, 878-881.

Ludwig K. A., Kelley D. S., Butterfield D. A., Nelson B. K. and Früh-Green G. (2006) Formation and evolution of carbonate chimneys at the Lost City Hydrothermal Field. Geochim. Cosmochim. Acta 70, 3625-3645.

Malvoisin B., Carlut J. and Brunet F. (2012) Serpentinization of oceanic peridotites: 1. A highsensitivity method to monitor magnetite production in hydrothermal experiments. $J$. Geophys. Res. 117, B01104, doi:10.1029/2011JB008612.

Marcaillou C., Muñoz M., Vidal O., Parra T. and Harfouche M. (2011) Mineralogical evidence for $\mathrm{H}_{2}$ degassing during serpentinization at $300^{\circ} \mathrm{C} / 300$ bar. Earth Planet. Sci. Lett. 303, 281-290.

McCollom T. M. (2008) Observational, experimental, and theoretical constraints on carbon cycling in mid-ocean ridge hydrothermal systems. In Magma to Microbe: Modeling Hydrothermal Processes at Ocean Spreading Centers (eds. R. P. Lowell, J. S. Seewald, A. Metaxas and M. R. Perfit). American Geophysical Union, Washington, DC, pp. 193-213.

McCollom T. M. and Bach W. (2009) Thermodynamic constraints on hydrogen generation during serpentinization of ultramafic rocks. Geochim. Cosmochim. Acta 73, 856-875.

McCollom T. M. and Seewald J. S. (2001) A reassessment of the potential for reduction of dissolved $\mathrm{CO}_{2}$ to hydrocarbons during serpentinization of olivine. Geochim. Cosmochim. Acta 65, 3769-3778.

McCollom T. M. and Seewald J. S. (2003) Experimental constraints on the hydrothermal reactivity of organic acids and acid anions: I. Formic acid and formate. Geochim. Cosmochim. Acta 67, 3625-3644.

McCollom T. M. and Seewald J. S. (2007) Abiotic synthesis of organic compounds in deep-sea hydrothermal environments. Chem. Rev. 107, 382-401.

Morse J. W. and Mackenzie F. T. (1998) Hadean ocean carbonate geochemistry. Aquat. Geochemistry 4, 301-319.

Mposkos E., Baziotis I., Proyer A. and Hoinkes G. (2006) Dolomitic marbles from the ultrahighpressure metamorphic Kimi complex in Rhodope, N.E. Greece. Mineral. Petrol. 88, 341362.

Müntener O. and Manatschal G. (2006) High degrees of melt extraction recorded by spinel harzburgite of the Newfoundland margin: The role of inheritance and consequences for the evolution of the southern North Atlantic. Earth Planet. Sci. Lett. 252, 437-452.

Naldrett A. J. (1966) Talc-carbonate alteration of some serpentinized ultramafic rocks south of Timmins, Ontario. J. Petrol. 7, 489-499.

Nordeng S. H. and Sibley D. F. (1994) Dolomite stoichiometry and Ostwald's Step Rule. Geochim. Cosmochim. Acta 58, 191-196.

Oskierski H. C., Dlugogorski B. Z. and Jacobsen G. (2013) Sequestration of atmospheric $\mathrm{CO}_{2}$ in 
a weathering-derived, serpentinite-hosted magnesite deposit: ${ }^{14} \mathrm{C}$ tracing of carbon sources and age constraints for a refined genetic model. Geochim. Cosmochim. Acta 122, 226-246.

Paukert A. N., Matter J. M., Kelemen P. B., Shock E. L. and Havig J. R. (2012) Reaction path modeling of enhanced in situ $\mathrm{CO}_{2}$ mineralization for carbon sequestration in the peridotite of the Samail Ophiolite, Sultanate of Oman. Chem. Geol. 330-331, 86-100.

Peuble S., Andreani M., Godard M., Gouze P., Barou F., Van de Moortele B., Mainprice D. and Reynard B. (2015a). Carbonate mineralization in percolated olivine aggregates: Linking effects of crystallographic orientation and fluid flow. Am. Mineral. 100, 474-482.

Peuble S., Godard M., Luquot L., Andreani M., Martinez I. and Gouze P. (2015b) $\mathrm{CO}_{2}$ geological storage in olivine rich basaltic aquifers: New insights from reactive-percolation experiments. Appl. Geochem. 52, 174-190.

Plümper O., Beinlich A., Bach W., Janots E. and Austrheim H. (2014) Garnets within geode-like serpentinite veins: Implications for element transport, hydrogen production and lifesupporting environment formation. Geochim. Cosmochim. Acta 141, 454-471.

Quesnel B., Gautier P., Boulvais P., Cathelineau M., Maurizot P., Cluzel D., Ulrich M., Guillot S., Lesimple S. and Couteau C. (2013) Syn-tectonic, meteoric water-derived carbonation of the New Caledonia peridotite nappe. Geology 41, 1063-1066.

Robinson P. T., Malpas J., Zhou M.-F., Ash C., Yang J.-S. and Bai W.-J. (2005) Geochemistry and origin of listwanites in the Sartohay and Luobusa Ophiolites, China. Int. Geol. Rev. 47, 177-202.

Schandl E. S. and Gorton M. P. (2012) Hydrothermal alteration and $\mathrm{CO}_{2}$ metasomatism (natural carbon sequestration) of komatiites in the south-western Abitibi greenstone belt. Can. Mineral. 50, 129-146.

Schandl E. S. and Naldrett A. J. (1992) $\mathrm{CO}_{2}$ metasomatism of serpentinites, south of Timmins, Ontario. Can. Mineral. 30, 93-108.

Schandl E. S. and Wicks F. J. (1991) Two stages of $\mathrm{CO}_{2}$ metasomatism at the Munro mine, Munro Township, Ontario: Evidence from fluid-inclusion, stable-isotope, and mineralogical studies. Can. J. Earth Sci. 28, 721-728.

Schandl E. S. and Wicks F. J. (1993) Carbonate and associated alteration of ultramafic and rhyolitic rocks at the Hemingway Property, Kidd Creek volcanic complex, Timmins, Ontario. Econ. Geol. 88, 1615-1635.

Schroeder T., Bach W., Jöns N., Jöns S., Monien P. and Klügel A. (2015) Fluid circulation and carbonate vein precipitation in the footwall of an oceanic core complex, Ocean Drilling Program Site 175, Mid-Atlantic Ridge. Geochem. Geophys. Geosyst. 16, 3716-3732.

Schroll E. (2002) Genesis of magnesite deposits in the view of isotope geochemistry. Bol. Parana. Geociênc. 50, 59-68.

Schwarzenbach E. M., Früh-Green G. L., Bernasconi S. M., Alt J. C. and Plas A. (2013) Serpentinization and carbon sequestration: A study of two ancient peridotite-hosted hydrothermal systems. Chem. Geol. 351, 115-133.

Schwarzenbach E. M., Caddick M. J., Beard J. S. and Bodnar R. J. (2016a) Serpentinization, element transfer, and the progressive development of zoning in veins: Evidence from a partially serpentinized harzburgite. Contrib. Mineral. Petrol. 171, doi:10.1007/s00410-0151219-3.

Schwarzenbach E. M., Gill B. C., Gazel E. and Madrigal P. (2016b) Sulfur and carbon geochemistry of the Santa Elena peridotites: Comparing oceanic and continental processes during peridotite alteration. Lithos 252-252, 92-108. 
Seifritz W. (1990) $\mathrm{CO}_{2}$ disposal by means of silicates. Nature 345, 486.

Seyfried W. E. Jr, Janecky D. R. and Berndt M. E. (1987) Rocking autoclaves for hydrothermal experiments, II. The flexible reaction-cell system. In Hydrothermal Experimental Techniques (eds. G. C. Ulmer and H. L. Barnes). John Wiley and Sons, New York, NY. pp. 216-239.

Seyfried W. E. Jr, Pester N. J., Tutolo B. M. and Ding K. (2015) The Lost City hydrothermal system: Constraints imposed by vent fluid chemistry and reaction path models on subseafloor heat and mass transfer processes. Geochim. Cosmochim. Acta 163, 59-79.

Sibley D. F. (1990) Unstable to stable transformations during dolomitization. J. Geol. 98, 739748.

Spandler C., Hermann J., Faure K., Mavrogenes J. A. and Arculus R. J. (2008) The importance of talc and chlorite "hybrid" rocks for volatile recycling through subduction zones; evidence from the high-pressure subduction mélange of New Caledonia. Contrib. Mineral. Petrol. 155, 181-198.

Stanger, N. (1985) Silicified serpentinite in the Semail nappe of Oman. Lithos 18, 13-22. Ulrich M., Muñoz M., Guillot S., Cathelineau M., Picard C., Quesnel B., Boulvais P. and Couteau C. (2014) Dissolution-precipitation processes governing the carbonation and silicification of the serpentinite sole of the New Caledonia ophiolite. Contrib. Mineral. Petrol. 167, 952.

van Noort R., Spiers C. J., Drury M. R. and Kandianis M. T. (2013) Peridotite dissolution and carbonation rates at fracture surfaces under conditions relevant for in situ mineralization of $\mathrm{CO}_{2}$. Geochim. Cosmochim. Acta 106, 1-24.

van Zuilen M. A., Lepland A., Teranes J., Finarelli J., Wahlen M. and Arrhenius G. (2003) Graphite and carbonates in the $3.8 \mathrm{Ga}$ old Isua Supracrustal Belt, southern West Greenland. Precambrian Res. 126, 331-348.

Von Damm K. L., Bray A. M., Buttermore L. G. and Oosting S. E. (1998) The geochemical controls on vent fluids from the Lucky Strike vent field, Mid-Atlantic Ridge. Earth Planet. Sci. Lett. 160, 521-536.

Wolery T. J. (1992) EQ3/6, A Software Package for Geochemical Modeling of Aqueous Systems: Theoretical Manual, User's Guide, and Related Documentation (Version 7.0)., Lawrence Livermore National Laboratory.

Woods J. T. and Mellon M. G. (1941) The Molybdenum blue reaction: A spectrophotometric study. Ind. Eng. Chem. Anal. Ed. 13, 760-764.

Zhao L., Sang L., Chen J., Ji J. and Teng H. H. (2010) Aqueous carbonation of natural brucite: Relevance to $\mathrm{CO}_{2}$ sequestration. Environ. Sci. Technol. 44, 406-11. 


\title{
Chapter 3
}

\section{Linking $\mathrm{CO}_{2}$ reduction and carbonate formation during peridotite-seawater- $\mathrm{CO}_{2}$ interactions}

\begin{abstract}
Laboratory experiments were conducted at $200-300^{\circ} \mathrm{C}, 35 \mathrm{MPa}$ to assess relative extents of carbonate formation and $\mathrm{CO}_{2}$ reduction during alteration of peridotite by $\mathrm{CO}_{2(a q)}$-rich fluids. Powdered harzburgite was initially reacted with a seawater chlorinity solution containing no added $\mathrm{CO}_{2}$ in two parallel experiments to simulate the reducing conditions associated with serpentinization in a mid-ocean ridge setting. After 5-7 months of reaction, a $\mathrm{CO}_{2(\mathrm{aq})}$-rich solution was injected into one of the experiments, while the second experiment was terminated to assess mineral-fluid phase relations during serpentinization. Fluids were periodically sampled, and concentrations of dissolved carbon species $\left(\mathrm{CO}_{2}, \mathrm{CH}_{4}\right.$, formate, methanol) were measured over time to quantify the production of reduced carbon compounds from aqueous reduction of $\mathrm{CO}_{2}$. Alteration solids were examined at the termination of each experiment to evaluate the extent of carbonate formation.

Fluid speciation and mineral analyses indicate that initial serpentinization of harzburgite in a $\mathrm{CO}_{2}$-poor system resulted in the formation of serpentine, brucite, and minor calcite at all temperatures, with the additional formation of magnetite at $300^{\circ} \mathrm{C}$. Subsequent injection of $\mathrm{CO}_{2(\mathrm{aq})}$ at $200^{\circ} \mathrm{C}$ caused magnesite to form at the expense of brucite, olivine, and orthopyroxene. Addition of $\mathrm{CO}_{2(a q)}$ at $300^{\circ} \mathrm{C}$, in comparison, lead to the formation of dolomite and minor magnesite at the expense of brucite and olivine. Significantly more carbonate minerals formed at higher temperatures, with carbonate-altered solids at $200^{\circ} \mathrm{C}$ and $300^{\circ} \mathrm{C}$ having bulk inorganic carbon contents of 0.32 and 1.00 wt.\%, respectively. Serpentine minerals remained unreactive at all temperatures and limited the availability of dissolved $\mathrm{Mg}$ for carbonate formation. While formate achieved metastable equilibrium with $\mathrm{CO}_{2(\mathrm{aq})}$ on laboratory timescales at $200-300^{\circ} \mathrm{C}$, total concentrations were low $(\leq 1.4 \mathrm{mmol} / \mathrm{kg})$ and accounted for only a minor carbon sink during mineral carbonation. Despite the high $\mathrm{H}_{2(a q)}$ concentrations generated during serpentinization of
\end{abstract}


harzburgite, strong kinetic barriers to both methanol and methane formation were present on laboratory time scales. Results from this study demonstrate that formation of carbonate minerals is the predominant sink for dissolved inorganic carbon at redox and temperature conditions typical for ultramafic-influenced seafloor hydrothermal systems. 


\section{INTRODUCTION}

Reaction of mantle peridotite and $\mathrm{CO}_{2}$-bearing aqueous fluids in shallow oceanic lithosphere can result in the formation of carbonate minerals, either through homogeneous precipitation from pore fluids, or replacement of silicate and hydroxide phases via mineral carbonation (Bonatti et al., 1974; Ludwig et al., 2006; Andreani et al., 2009; Eickmann et al., 2009; Kelemen et al., 2011; Bach et al., 2011; Alt et al., 2013; Bach et al., 2013; Schwarzenbach et al., 2013; Schroeder et al., 2015; Klein et al., 2015b). Competing with this process is the reduction of $\mathrm{CO}_{2}$ to $\mathrm{CH}_{4}$ and other hydrocarbons under reducing conditions generated during serpentinization of mantle rocks (e.g., Charlou et al., 2002; McCollom and Seewald, 2007; Proskurowski et al., 2008; Charlou et al., 2010; Lang et al., 2010; McDermott et al., 2015). These two processes play key roles in cycling carbon and sustaining microbial life in subseafloor and deep ocean environments. Yet, the linkages between carbonate formation and $\mathrm{CO}_{2}$ reduction during peridotite-seawater- $\mathrm{CO}_{2}$ interactions remain poorly constrained. A number of field, laboratory, and theoretical studies have examined carbonate formation and $\mathrm{CO}_{2}$ reduction during alteration of peridotite by $\mathrm{CO}_{2}$-rich fluids (e.g., Berndt et al., 1996; McCollom and Seewald, 2001; Andreani et al., 2009; Jones et al., 2010; Hövelmann et al., 2011; van Noort et al., 2013). However, few studies have investigated these processes together. Several laboratory experiments investigating abiotic organic synthesis have reported the formation of carbonate minerals (McCollom and Seewald, 2001; McCollom and Seewald, 2003; McCollom et al., 2010; Jones et al., 2010), yet none have quantified their abundance. In addition, few experimental studies of mineral carbonation have documented the formation of organic compounds (Orlando et al., 2011; Klein and McCollom, 2013), and none have measured reduced carbon species other than $\mathrm{CH}_{4(a q)}$ (e.g., formate, formaldehyde, methanol). Recent evidence from ultramafic-influenced hydrothermal sites on the seafloor demonstrates that the intermediate carbon species formate actively forms during shallow fluid mixing (Lang et al., 2010; McDermott et al., 2015). Formate can supply energy and fixed carbon to methanogens inhabiting subsurface mixing zones and may, thus, represent an important metabolic substrate in serpentinization systems (Hedderich and Whitman, 2006). Examining how carbon is distributed among reduced carbon compounds and carbonate in subseafloor environments is thus critical in assessing carbon budgets and the potential habitability of seafloor serpentinization systems. 
The purpose of this study was to investigate carbon transformation pathways during hydrothermal alteration of peridotite under strongly reducing conditions. Laboratory experiments were conducted at $200-300^{\circ} \mathrm{C}$ and $35 \mathrm{MPa}$ to assess the relative extents of $\mathrm{CO}_{2}$ reduction and carbonate formation during interaction of peridotite and $\mathrm{CO}_{2}$-bearing aqueous fluids. Fluid composition and mineralogy were analyzed and compared with thermodynamic predictions for each experiment. Findings from this study elucidate the role that temperature and kinetics play in regulating the distribution of carbon in seafloor serpentinization systems.

This study builds on the findings of Chapter 2 by investigating the formation of reduced carbon intermediaries (formate, methanol) in addition to $\mathrm{CH}_{4(a q)}$ during alteration of harzburgite by $\mathrm{CO}_{2}$-rich hydrous fluids. Furthermore, it examines carbon and silicate reactions at a wider range of temperatures, from $200^{\circ} \mathrm{C}$ to $300^{\circ} \mathrm{C}$. By conducting two parallel experiments at each temperature condition, mineral-fluid phase relations could be assessed after alteration of peridotite by both $\mathrm{CO}_{2}$-poor and $\mathrm{CO}_{2}$-rich fluids. All experiments presented here were conducted using the same harzburgite protolith as Chapter 2, but with a smaller size fraction to achieve faster reaction rates. In addition, the starting solution contained much lower concentrations of dissolved $\mathrm{Ca}(\sim 10 \mathrm{mmol} / \mathrm{kg})$ relative to the starting solution used in Chapter $2(\sim 30 \mathrm{mmol} / \mathrm{kg})$. This was done to simulate reaction of harzburgite with less evolved hydrothermal fluids. Lower dissolved $\mathrm{Ca}$ concentrations resulted in higher $\mathrm{Mg} / \mathrm{Ca}$ ratios in interacting fluids and led to the precipitation of correspondingly more Mg-rich carbonate minerals relative to the Chapter 2 experiment. Finally, higher initial $\mathrm{CO}_{2(\text { aq) }}$ concentrations were attained during carbonation in the present experiments $(\sim 500 \mathrm{mmol} / \mathrm{kg})$ compared to that in Chapter $2(\sim 400 \mathrm{mmol} / \mathrm{kg})$.

\section{MATERIALS AND METHODS}

\subsection{Starting materials}

$\mathrm{A} \mathrm{Mg}$ - and $\mathrm{SO}_{4}$-free seawater chlorinity starting solution was used in all experimental runs (Tables 3.1 and 3.2). Its composition was selected to represent an evolved hydrothermal fluid prior to interaction with mantle peridotite. The starting solution was prepared by mixing reagent grade $\mathrm{NaCl}$ and $\mathrm{CaCl}_{2} \cdot \mathrm{H}_{2} \mathrm{O}$ with deionized water.

A fresh mantle xenolith from the Meerfelder Maar (Eifel Volcanic Field, Germany) was

used as the peridotite protolith in all experiments to avoid alteration products that are pervasive in oceanic peridotites (Snow and Dick, 1995). The xenolith is classified as a spinel harzburgite 
and is composed of $\sim 70$ vol. $\%$ olivine, 26 vol. $\%$ orthopyroxene, 4 vol.\% clinopyroxene, 0.9 vol.\% Cr- spinel, and trace ( $<0.1$ vol.\%) amphibole, glass, and primary sulfides including pentlandite and pyrrhotite. A more detailed description of its mineralogical and chemical composition can be found in Chapter 2 and Klein et al. (2015). Harzburgite is the most abundant peridotite sampled along slow-spreading mid-ocean ridges (Dick et al., 1984; Michael and Bonatti, 1985) and represents a key component of mantle rocks exposed at crustal levels. The xenolith was cut using a diamond drill to remove any alteration rims, and ground to a powder using a tungsten-carbide disk mill. The powder was then wet sieved to collect the 45-75 $\mu \mathrm{m}$ fraction, triply rinsed in deionized water, and dried at $40^{\circ} \mathrm{C}$ in air. The BET specific surface area of the harzburgite powder was measured as $0.7577 \mathrm{~m}^{2} / \mathrm{g}$ via 3-point krypton adsorption using a Micromeritics ASAP 2020 surface area analyzer. A rock powder was used as the starting reactant in place of a whole rock to speed up kinetic rates and allow for the examination of fluidrock reactions on laboratory time scales.

\subsection{Experimental methods}

All experiments were conducted in a flexible-cell hydrothermal apparatus (Seyfried et al., 1987). The apparatus consists of a gold reaction cell enclosed in a stainless steel pressure vessel that uses water as the pressure medium. The flexible nature of the gold cell allows experiments to be conducted at constant pressure with no vapor headspace. The reaction cell is connected to a titanium capillary tube and valve that permits fluids to be extracted from or injected into the hydrothermal apparatus during the course of the experiments without disturbing temperature or pressure.

Experiments were performed at temperatures of 200 and $300^{\circ} \mathrm{C}$, and a pressure of 35 MPa. Two parallel experiments were conducted at each temperature condition. In the first stage of both experiments, powdered harzburgite was reacted with a seawater chlorinity starting solution containing no added $\mathrm{CO}_{2}$ at an initial water-rock (W/R) ratio of $\sim 2$ for 5.5-7 months. This first step was intended to generate high $\mathrm{H}_{2(\text { aq) }}$ concentrations associated with serpentinization of peridotite in order to examine subsequent carbon reactions under strongly reducing conditions. An initial $\mathrm{W} / \mathrm{R}$ ratio of 2 was selected to simulate $\mathrm{W} / \mathrm{R}$ ratios typically estimated for submarine hydrothermal systems (Von Damm, 1995). Fluids (0.3-2.0 g each) were periodically extracted from the reaction cell directly into gas-tight glass syringes and were 
analyzed to monitor changes in fluid composition over time. Following this first serpentinization stage, a $\mathrm{CO}_{2(a q)}$-enriched starting solution was injected into one of the experiments to achieve an initial $\mathrm{CO}_{2(a q)}$ concentration of $\sim 500 \mathrm{mmol} / \mathrm{kg}$ in the reaction cell. The other experiment was terminated by cooling the hydrothermal apparatus to room temperature and depressurizing the reaction cell in order to assess mineral-fluid phase relations at the end of the initial serpentinization stage.

The injection was performed using a $150 \mathrm{~mL}$ titanium piston-cylinder. The pistoncylinder was first connected to a $\mathrm{CO}_{2(g)}(99.8 \%)$ tank and filled with gas. Starting solution was then added and the piston-cylinder was pressurized to $\geq 13.8 \mathrm{MPa}$ for at least 12 hours to allow $\mathrm{CO}_{2(g)}$ to dissolve in the fluid. Finally, the piston-cylinder was connected to the titanium valve of the hydrothermal apparatus, and $\mathrm{CO}_{2(a q)}$-rich fluid was pumped into the reaction cell and allowed to react with the serpentinized harzburgite for 3.5-4.5 months. Fluids were sampled immediately following the $\mathrm{CO}_{2}$ injection, and after increasing time intervals, to monitor changes in fluid chemistry. At the termination of each experiment, solid alteration products were removed from the reaction cell, rinsed with deionized water, and dried at $40^{\circ} \mathrm{C}$ in air.

\subsection{Analytical methods}

Fluids sampled from each experiment were analyzed for $\mathrm{pH}\left(25^{\circ} \mathrm{C}\right)$, major ions, formate, methanol, and dissolved $\mathrm{SiO}_{2}, \mathrm{H}_{2}, \mathrm{CH}_{4}$, and $\mathrm{CO}_{2}$. Most of the data reported in Tables 3.1 and 3.2 represent the average concentration in 2 replicate fluid samples. The $\mathrm{pH}\left(25^{\circ} \mathrm{C}\right)$ was measured using a micro-combination electrode with $\mathrm{Ag} / \mathrm{AgCl}$ reference. Major ions (Cl, $\mathrm{Na}, \mathrm{K}, \mathrm{Mg}, \mathrm{Ca}$ ) and total formate $\left(\Sigma\right.$ formate $\left.=\mathrm{HCOOH}_{(a q)}+\mathrm{HCOO}^{-}\right)$were analyzed by ion chromatography with suppressed conductivity detection. Dissolved $\mathrm{SiO}_{2}$ was measured spectrophotometrically using the heteropoly blue method (Woods and Mellon, 1941). Concentrations of dissolved volatile gases $\left(\mathrm{H}_{2}, \mathrm{CH}_{4}, \mathrm{CO}_{2}\right)$ were determined by gas chromatography $(\mathrm{GC})$. Dissolved $\mathrm{H}_{2}$ was quantified following a headspace extraction with $\mathrm{N}_{2}$ using a GC equipped with a thermal conductivity detector. Dissolved $\mathrm{CH}_{4}$ and total $\mathrm{CO}_{2}\left(\Sigma \mathrm{CO}_{2}=\mathrm{CO}_{2}+\mathrm{HCO}_{3}{ }^{-}+\mathrm{CO}_{3}{ }^{2-}\right)$ were analyzed using a purge and trap device interfaced to a GC equipped with serially connected thermal conductivity and flame ionization detectors. Samples for total $\mathrm{CO}_{2}$ analysis were acidified with $25 \mathrm{wt}$ \% phosphoric acid prior to injection into the GC to ensure complete extraction of all dissolved inorganic carbon species as $\mathrm{CO}_{2}$. 
Although methanol is a volatile compound, it forms strong hydrogen bonds with water, making it difficult to extract from aqueous solutions through purging. Fluids with low chlorinity can be analyzed for methanol by direct injection into a GC. However, injection of fluids with seawater chlorinity results in plugging of the injection device with salt crystals. To circumvent this problem, a method was developed to analyze methanol in solutions of seawater chlorinity involving distillation of the solution prior to its introduction into a GC (Figure 3.1). A small fluid sample (1-2 $\mu \mathrm{L})$ was injected into a Pyrex tube heated to $125^{\circ} \mathrm{C}$ and under a stream of helium carrier gas. Heating of the sample resulted in vaporization of methanol and water, and crystallization of salts inside the Pyrex tube. Methanol and water vapor were then transported by the helium flow and focused onto a cryogenic trap immersed in liquid $\mathrm{N}_{2}$. The sample was subsequently injected into a GC equipped with a Hayesep-Q packed column and flame ionization detector.

Thin sections of the solid alteration products were prepared in oil at High Mesa Petrographics (Los Alamos, NM) to avoid dissolution of water-soluble phases and oxidation of $\mathrm{Fe}^{2+}$-bearing minerals. Thin sections were imaged with a petrographic microscope in transmitted and reflected light, and with a Hitachi TM3000 scanning electron microscope (SEM) in backscattered electron (BSE) mode. The SEM was coupled to a Bruker-Quantax 70 energy dispersive x-ray spectrometer (EDS) operated at a $15 \mathrm{kV}$ accelerating voltage under low-vacuum to allow for semi-quantitative analysis of primary and secondary minerals. Minerals were identified with a Horiba Jobin-Yvon LabRAM HR confocal Raman spectrometer. Raman spectra were typically acquired using a $633 \mathrm{~nm}$ laser, $600 \mathrm{~mm}^{-1}$ grating, and $100 \mu \mathrm{m}$ slit size, and represent the average of three acquisitions. Mineral compositions were quantified with a JEOL-JXA-8530F fieldemission electron probe microanalyzer operated at a $15 \mathrm{kV}$ accelerating voltage and $10 \mathrm{nA}$ beam current. The beam diameter was set to 6-10 $\mu \mathrm{m}$ for analyses of hydrous silicates and carbonates to avoid volatile loss, and was fully-focused for analyses of primary silicates, oxides, and sulfides.

Volumes of the starting material and solid alteration products were measured with a Micromeritics AccuPyc II 1340 helium pycnometer and were used to calculate density changes during the experiments. Bulk magnetic susceptibility was determined using a Bartington MS2B Dual Frequency Sensor. Whole-rock major element compositions were quantified by x-ray fluorescence (XRF) fusion at Activation Laboratories, Inc using a Panalytical Axios Advanced 
wavelength dispersive XRF. Bulk FeO contents were determined by titration at Activation Laboratories, Inc following a cold acid digestion. The starting material and experimental products were analyzed by elemental analysis before and after acidification to quantify bulk total carbon $(\% \mathrm{TC})$, organic carbon $(\% \mathrm{OC})$, and inorganic carbon $(\% \mathrm{IC})$ contents. Solids were analyzed using a Costech 4010 elemental analyzer, coupled to a Thermo Delta-V-Plus isotope ratio mass spectrometer via a Finnigan-MAT Conflo-II interface. A more detailed description of the methods is found in Whiteside et al. (2011).

\subsection{Thermodynamic calculations}

The equilibrium distribution of aqueous species at in situ conditions was calculated for all fluid samples using the EQ3/6 software code (Wolery, 1992). Thermodynamic calculations were performed using a customized thermodynamic database for $35 \mathrm{MPa}$ assembled using SUPCRT92 (Johnson et al., 1992). Activity coefficients for charged species were calculated using the B-dot equation, with hardcore diameters, B-dot parameters, and Debye-Hückel parameters obtained from Wolery and Jove-Colon (2004). Activity coefficients for neutral species were assigned values of unity, except for non-polar gases, which were assigned values for $\mathrm{CO}_{2}$ after Drummond (1981). More detailed information on the thermodynamic database can be found in Klein et al. (2009) and McCollom and Bach (2009).

During the $\mathrm{CO}_{2}$-poor stages of the experiments, in situ $\mathrm{pH}$ was calculated by speciating the measured fluid composition and $\mathrm{pH}$ at $25^{\circ} \mathrm{C}$, and then re-speciating the fluid composition at the experimental conditions while conserving mass and charge. For samples with $\mathrm{Mg}$ concentrations below the detection limit of ion chromatography, the method detection limit of $\mathrm{Mg}(5 \mu \mathrm{g} / \mathrm{L})$ was used for thermodynamic calculations. Fluids analyzed after addition of a $\mathrm{CO}_{2}-$ rich fluid have uncertain $\mathrm{pH}\left(25^{\circ} \mathrm{C}\right)$ values due to degassing of $\mathrm{CO}_{2}$ during the $\mathrm{pH}$ measurements. Therefore, in situ $\mathrm{pH}$ for fluids with high $\mathrm{CO}_{2}$ concentrations was estimated assuming equilibrium between carbonate minerals (dolomite or magnesite) and the bulk fluid at in situ conditions. Carbonate-fluid equilibrium is supported by the presence of euhedral carbonate crystals at the end of each experiment, and by relatively rapid carbonate precipitation kinetics at temperatures $\geq 200^{\circ} \mathrm{C}$, particularly at high carbonate concentrations and low $\mathrm{pH}$ (Arvidson and Mackenzie, 1997; Saldi et al., 2012). 


\section{RESULTS}

\section{1. $\mathrm{CO}_{2}$-poor serpentinization at $200^{\circ} \mathrm{C}$ and $300^{\circ} \mathrm{C}$}

\subsubsection{Fluid chemistry}

Alteration of harzburgite by $\mathrm{CO}_{2}$-poor fluids resulted in large changes in fluid chemistry at $200^{\circ} \mathrm{C}$ and $300^{\circ} \mathrm{C}$ (Tables 3.1 and 3.2, Figure 3.2). The $\mathrm{CO}_{2}$-poor stages of the two replicate experiments at each temperature exhibited remarkably reproducible fluid compositions. Highly alkaline fluids were generated at both temperature conditions. At $200^{\circ} \mathrm{C}, \mathrm{pH}\left(25^{\circ} \mathrm{C}\right)$ increased to $>11$ after $\sim 400$ hours of reaction and plateaued at 11.5 . At $300^{\circ} \mathrm{C}, \mathrm{pH}\left(25^{\circ} \mathrm{C}\right)$ increased more slowly and reached less alkaline steady-state values of 10.7-10.8. Considerable amounts of $\mathrm{H}_{2(a q)}$ were produced in all experiments. Dissolved $\mathrm{H}_{2}$ concentrations increased nearly linearly during serpentinization at $200^{\circ} \mathrm{C}$, reaching values of $35.6-37.5 \mathrm{mmol} / \mathrm{kg}$ after $\sim 3900$ hours of reaction. $\mathrm{H}_{2(a q)}$ concentrations at $300^{\circ} \mathrm{C}$ increased to higher values in the same time period, and reached a maximum of $106 \mathrm{mmol} / \mathrm{kg}$ after 5189 hours of reaction. Small quantities of dissolved $\mathrm{CH}_{4}$ were also generated in the experiments, reaching values of 16 and $38 \mu \mathrm{mol} / \mathrm{kg}$ at $200^{\circ} \mathrm{C}$ and $300^{\circ} \mathrm{C}$, respectively. The rate of $\mathrm{CH}_{4(a q)}$ production was initially fast at both temperatures and slowed over time. Although no $\mathrm{CO}_{2}$ was added to the starting solution, low levels of background $\Sigma \mathrm{CO}_{2}$ $(<0.2 \mathrm{mmol} / \mathrm{kg})$ were detected in all sampled fluids during the $\mathrm{CO}_{2}$-poor serpentinization stages, with $\Sigma \mathrm{CO}_{2}$ concentrations showing a small, but measureable, decrease over time. $\mathrm{SiO}_{2(a q)}$ concentrations were initially elevated in the first sample of all experiments, and then decreased to low values $\left(\leq 0.07 \mathrm{mmol} / \mathrm{kg}\right.$ ) for the remainder of the $\mathrm{CO}_{2}$-poor serpentinization period. Although $\mathrm{SiO}_{2(a q)}$ concentrations exhibited some variability between replicate experiments at the same temperature, they were on average lower at $200^{\circ} \mathrm{C}$ than at $300^{\circ} \mathrm{C} . \mathrm{Mg}$ concentrations were below or near the detection limit in all $\mathrm{CO}_{2}$-poor fluids. Concentrations of dissolved $\mathrm{Ca}$ decreased significantly during $\mathrm{CO}_{2}$-poor serpentinization, from $9.6 \mathrm{mmol} / \mathrm{kg}$ in the starting solution to a minimum of $5.4 \mathrm{mmol} / \mathrm{kg}$ and $2.4 \mathrm{mmol} / \mathrm{kg}$ at $200^{\circ} \mathrm{C}$ and $300^{\circ} \mathrm{C}$, respectively. Concentrations of dissolved $\mathrm{Na}$ and $\mathrm{Cl}$ slightly increased during serpentinization of harzburgite, most likely reflecting the uptake of water into hydrous minerals. Fluids at the end of the $\mathrm{CO}_{2}$ poor serpentinization stages contained low, but detectable, quantities of methanol ( $22 \mu \mathrm{mol} / \mathrm{kg}$ and $11 \mu \mathrm{mol} / \mathrm{kg}$ at 200 and $300^{\circ} \mathrm{C}$, respectively). Formate was below the detection limit of ion chromatography at all temperatures in the $\mathrm{CO}_{2}$-poor experiments. 
Comparison of the $300^{\circ} \mathrm{C}$ experiment described in Chapter 2 with the present experiments conducted at the same temperature reveal similar inorganic fluid chemistries during $\mathrm{CO}_{2}$-poor serpentinization of harzburgite. Fluids in both sets of experiments were strongly alkaline and depleted in dissolved $\mathrm{SiO}_{2}, \mathrm{Mg}$, and $\Sigma \mathrm{CO}_{2}$ prior to the injection of a $\mathrm{CO}_{2}$-enriched fluid. The main differences lie in the dissolved $\mathrm{Ca}$ and $\mathrm{H}_{2}$ concentrations. $\mathrm{H}_{2(a q)}$ reached much higher concentrations in the present experiments (up to $106 \mathrm{mmol} / \mathrm{kg}$ ) compared to that of Chapter 2 (up to $63 \mathrm{mmol} / \mathrm{kg}$ ). In addition, $\mathrm{CO}_{2}$-poor serpentinization fluids in Chapter 2 contained higher quantities of dissolved $\mathrm{Ca}$, mainly reflecting the higher $\mathrm{Ca}$ concentration of the starting solution.

\subsubsection{Petrography of serpentinization products}

Alteration of harzburgite powder by $\mathrm{CO}_{2}$-poor aqueous solutions at $200^{\circ} \mathrm{C}$ and $300^{\circ} \mathrm{C}$ resulted in the overgrowth and partial to complete replacement of primary silicates by secondary minerals. Thin section image analysis revealed that secondary minerals make up approximately 68 vol. $\%$ of the solids altered at $200^{\circ} \mathrm{C}$. Harzburgite underwent a higher extent of serpentinization at $300^{\circ} \mathrm{C}$; solid products recovered from experiment 3 are composed of $\sim 94 \%$ secondary minerals, according to thin section image analysis. At all temperatures, thin chrysotile fibers precipitated onto original primary mineral surfaces and grew into the interstitial spaces, forming an interconnected network of chrysotile rims that cemented together the initial harzburgite powder (Figure 3.3). Chrysotile rims precipitated at $200^{\circ} \mathrm{C}$ are $2-20 \mu \mathrm{m}$ wide, and appear more densely packed and discrete than those formed at $300^{\circ} \mathrm{C}$, with the surrounding pore spaces typically devoid of chrysotile fibers. In contrast, solids recovered from the $300^{\circ} \mathrm{C}$ experiment exhibit more diffuse growth of chrysotile throughout all pore spaces, making it difficult to discriminate the width of the chrysotile overgrowths. Nevertheless, abundant pore space was still preserved at all temperatures. Thin section image analysis indicated a porosity of $\sim 26$ vol. $\%$ and 23 vol.\% in the solid products recovered from the $200^{\circ} \mathrm{C}$ and $300^{\circ} \mathrm{C}$ experiments, respectively.

Olivine was partially to completely replaced by secondary minerals during $\mathrm{CO}_{2}$-poor serpentinization at $200^{\circ} \mathrm{C}$ and $300^{\circ} \mathrm{C}$ (Figure 3.3a-b,f-g). Relict olivine at both temperatures exhibits abundant dissolution features, including conical, denticulate, and linear etch pits.

Olivine is typically overgrown by a continuous layer of chrysotile, with abundant pore space 
present between the relict primary mineral and surrounding chrysotile rim. $\mathrm{CO}_{2}$-poor serpentinization at $200^{\circ} \mathrm{C}$ resulted in the direct replacement of olivine by spherical (polyhedral?) serpentine and brucite (Figure 3.3a-b). Serpentine occurs as small spherical grains, 1-4 $\mu \mathrm{m}$ in diameter, that partially fill the pore space immediately surrounding relict olivine. It is also observed to line the inside surface of the chrysotile rim, forming a semi-continuous to continuous layer. The spherical morphology of these serpentine grains is consistent with the presence of polyhedral serpentine. However, the high degree of similarity between the Raman spectra of polyhedral serpentine and lizardite precludes confirmation of its structure. Brucite occurs as thin plates, $<1 \mu \mathrm{m}$ thick, that radiate outward from the relict olivine surface (Figure 3.3b), or extend from one part of the chrysotile rim to another (Figure 3.3a). No magnetite was detected in the solid products recovered at $200^{\circ} \mathrm{C}$ by either optical, Raman, or electron microprobe analyses. In contrast to the $200^{\circ} \mathrm{C}$ experiments, $\mathrm{CO}_{2}$-poor serpentinization at $300^{\circ} \mathrm{C}$ resulted in the replacement of olivine by magnetite, in addition to serpentine and brucite (Figure 3.3f-g). Brucite occurs as elongated pseudohexagonal plates, 1-10 $\mu \mathrm{m}$ thick, that radiate outward from the relict olivine surface or span the entire length of the cavity immediately surrounding relict olivine. Less commonly, brucite plates are arranged in radiating spherules. Magnetite occurs as euhedral to subhedral crystals up to $5 \mu \mathrm{m}$, but more commonly 1-2.5 $\mu \mathrm{m}$, in diameter. Magnetite is typically situated between brucite and the surrounding serpentine, but smaller crystals are also intergrown with brucite. Brucite + magnetite \pm olivine is rimmed by very fine-grained platy and fibrous serpentine minerals having the Raman spectra of lizardite.

Orthopyroxene underwent partial to complete replacement by secondary minerals during $\mathrm{CO}_{2}$-poor serpentinization at $200^{\circ} \mathrm{C}$ (Figure 3.3c). Relict orthopyroxene exhibits abundant linear etch pits. It is overgrown by a continuous layer of fibrous chrysotile, and abundant pore space is present between the relict orthopyroxene and chrysotile rim. This pore space is partially filled with spherical (polyhedral?) serpentine, 1-5 $\mu \mathrm{m}$ in diameter. Spherical serpentine grains also line the inside surface of the chrysotile rim, forming a semi-continuous to continuous layer. $\mathrm{CO}_{2}$-poor serpentinization at $300^{\circ} \mathrm{C}$, in contrast, resulted in the near complete alteration of orthopyroxene, with only rare relict orthopyroxene observed in the solid products. Where primary silicates are completely altered at $300^{\circ} \mathrm{C}$, they are replaced by serpentine \pm magnetite (Figure $3.3 \mathrm{~h}$ ).

Magnetite appears as euhedral to subhedral crystals 1-5 $\mu \mathrm{m}$ in diameter. It occurs as larger grains clustered in the center of the completely replaced primary mineral, or as smaller grains 
intergrown with serpentine. Serpentine minerals are much finer-grained, typically $<1 \mu \mathrm{m}$ in diameter, and exhibit platy, fibrous, and spherical habits.

Clinopyroxene exhibits little to no alteration following $\mathrm{CO}_{2}$-poor serpentinization at $200^{\circ} \mathrm{C}$ and $300^{\circ} \mathrm{C}$ (Figure $3.3 \mathrm{~d}, \mathrm{i}$ ). At both temperatures, clinopyroxene is covered in a continuous layer of chrysotile, with little pore space present between clinopyroxene and the surrounding chrysotile rim. Clinopyroxene edges remain sharp and angular, with little to no etch pits observed. However, a few clinopyroxene grains were apparently partially altered to serpentine and magnetite in the $300^{\circ} \mathrm{C}$ serpentinization experiment (Figure 3.3i).

Chrysotile fibers are observed to coat $\mathrm{Cr}$-spinel at all temperatures. With the exception of minor grains rimmed by magnetite in the $300^{\circ} \mathrm{C}$ experiment and rare etch pits observed in the $200^{\circ} \mathrm{C}$ experiment, Cr-spinel shows no obvious signs of dissolution. Secondary sulfides precipitated during $\mathrm{CO}_{2}$-poor serpentinization at $200^{\circ} \mathrm{C}$ and $300^{\circ} \mathrm{C}$. Alteration products recovered from the $200^{\circ} \mathrm{C}$ experiment contain euhedral pyrite, $<1-6 \mu \mathrm{m}$ in diameter, as determined by electron microprobe analyses. In contrast, solid products from the $300^{\circ} \mathrm{C}$ experiment contain secondary heazlewoodite according to electron microprobe analyses. Heazlewoodite occurs as subhedral to anhedral crystals, 5-10 $\mu \mathrm{m}$ across, overgrown by magnetite (Figure 3.3g). In addition, awaruite was tentatively identified at $300^{\circ} \mathrm{C}$ by energy dispersive $x$-ray spectroscopy. Trace euhedral calcite, 5-15 $\mu \mathrm{m}$ in diameter, was observed in solid reaction products from both the $200^{\circ} \mathrm{C}$ and $300^{\circ} \mathrm{C}$ serpentinization experiments (Figure $3.3 e, j)$.

\subsubsection{Secondary mineral chemistry}

Serpentine minerals formed during $\mathrm{CO}_{2}$-poor serpentinization at $300^{\circ} \mathrm{C}$ exhibit systematic differences in $\mathrm{FeO}, \mathrm{Al}_{2} \mathrm{O}_{3}, \mathrm{NiO}$, and $\mathrm{Cr}_{2} \mathrm{O}_{3}$ contents that reflect compositional differences in their primary silicate precursors (Table 3.4). Serpentine after orthopyroxene is moderately enriched in $\mathrm{FeO}, \mathrm{Al}_{2} \mathrm{O}_{3}$, and $\mathrm{Cr}_{2} \mathrm{O}_{3}$, but depleted in $\mathrm{NiO}$, relative to serpentine after olivine. $\mathrm{Mg \# s}$ of serpentine after orthopyroxene range from 90.5 to 91.5 , while $\mathrm{Mg \# s}$ of serpentine after olivine are slightly higher, spanning 92.5-92.9. Brucite produced by serpentinization of olivine at $300^{\circ} \mathrm{C}$ is relatively Fe-rich, with $\mathrm{Mg \# s}$ of 86.7-88.7, and has a minor $\mathrm{Cl}$ component (1.4-1.7 wt.\%). 
Hydrous minerals formed during $\mathrm{CO}_{2}$-poor serpentinization at $200^{\circ} \mathrm{C}$ were typically smaller than the beam diameter required for electron microprobe analysis. Thus, it was not possible to determine the composition of brucite and serpentine minerals formed at $200^{\circ} \mathrm{C}$, with the exception of 3 analyses of serpentine after olivine (Table 3.3). Serpentine formed after olivine at $200^{\circ} \mathrm{C}$ appears to have a similar $\mathrm{Mg} \#(91.9-92.5)$ to that formed at $300^{\circ} \mathrm{C}$.

\subsubsection{Bulk physical and chemical properties}

Bulk chemical compositions of the harzburgite starting material and experimental alteration products are presented in Table 3.5. The harzburgite starting material has a bulk density of $3.33 \mathrm{~g} / \mathrm{cm}^{3}$ and no detectable loss on ignition. The bulk density decreased to 2.98 $\mathrm{g} / \mathrm{cm}^{3}$ following $\mathrm{CO}_{2}$-poor serpentinization at $200^{\circ} \mathrm{C}$, as less dense brucite and serpentine minerals were produced. It further decreased to $2.72 \mathrm{~g} / \mathrm{cm}^{3}$ during serpentinization at $300^{\circ} \mathrm{C}$, consistent with the higher extent of reaction at this temperature. Formation of hydrous minerals during serpentinization also resulted in an increase in the loss on ignition to $6.60 \mathrm{wt} \% \%$ and 11.99 wt. $\%$ in the solids recovered from the $200^{\circ} \mathrm{C}$ and $300^{\circ} \mathrm{C}$ experiments, respectively.

Mössbauer analysis revealed no detectable Fe(III) in the harzburgite starting material, indicating that $\mathrm{Fe}^{3+} / \Sigma \mathrm{Fe}$ of the bulk solids is close to 0 (Klein et al., 2015a). Yet, unaltered harzburgite has a volume-specific magnetic susceptibility of $4.91 \times 10^{-4}$ S.I., suggesting that trace ferromagnetic minerals are present. Although $\mathrm{Fe}^{3+} / \Sigma \mathrm{Fe}$ increased to 0.26 following $\mathrm{CO}_{2}$-poor serpentinization at $200^{\circ} \mathrm{C}$, magnetic susceptibility remained essentially constant $\left(4.98 \times 10^{-4}\right.$ S.I. $)$. In contrast, serpentinization at $300^{\circ} \mathrm{C}$ resulted in a significant increase in both $\mathrm{Fe}^{3+} / \Sigma \mathrm{Fe}(0.56)$ and magnetic susceptibility $\left(1.57 \times 10^{-2}\right.$ S.I. $)$ due to the formation of magnetite.

The harzburgite starting material contains very low concentrations of total carbon $(0.01$ wt.\%), with essentially all carbon present as organic compounds. Serpentinization in a $\mathrm{CO}_{2}$-poor system lead to a small increase in the inorganic carbon content to $0.03 \mathrm{wt} . \%$ at both $200^{\circ} \mathrm{C}$ and $300^{\circ} \mathrm{C}$, as minor calcite precipitated. This corresponds to a calcite content of $0.25 \mathrm{wt} . \%$.

\subsection{Carbonation at $200^{\circ} \mathrm{C}$ and $300^{\circ} \mathrm{C}$}

\subsubsection{Fluid chemistry}

Injection of $\mathrm{a} \mathrm{CO}_{2(a q)}$-rich aqueous solution into an active serpentinization system resulted in large and rapid changes in fluid chemistry at $200^{\circ} \mathrm{C}$ and $300^{\circ} \mathrm{C}$ (Tables 3.1 and 3.2, 
Figure 3.2). The concentration of dissolved $\Sigma \mathrm{CO}_{2}$ in the first sample taken after the injection was $427 \mathrm{mmol} / \mathrm{kg}$ and $474 \mathrm{mmol} / \mathrm{kg}$ at $200^{\circ} \mathrm{C}$ and $300^{\circ} \mathrm{C}$, respectively. $\Sigma \mathrm{CO}_{2(a q)}$ concentrations showed rapid subsequent decreases that slowed with time, reaching a minimum of $12 \mathrm{mmol} / \mathrm{kg}$ after 2639 hours of reaction at $200^{\circ} \mathrm{C}$, and $38 \mathrm{mmol} / \mathrm{kg}$ after 3222 hours of reaction at $300^{\circ} \mathrm{C}$. The addition of $\mathrm{CO}_{2}$ also resulted in a substantial decrease in $\mathrm{pH}\left(25^{\circ} \mathrm{C}\right)$ immediately after the injection to 5.8 and 5.2 at $200^{\circ} \mathrm{C}$ and $300^{\circ} \mathrm{C}$, respectively. The $\mathrm{pH}\left(25^{\circ} \mathrm{C}\right)$ did not change appreciably as the reaction progressed at $200^{\circ} \mathrm{C}$, but increased slightly with continued reaction at $300^{\circ} \mathrm{C}$. Concentrations of dissolved $\mathrm{H}_{2}$ and $\mathrm{CH}_{4}$ initially decreased after injection of $\mathrm{CO}_{2}$, mainly due to dilution with the added fluid. $\mathrm{CH}_{4(a q)}$ concentrations subsequently increased at both temperatures. $\mathrm{H}_{2(a q)}$ concentrations continued to decline in the $200^{\circ} \mathrm{C}$ experiment, but remained the same within analytical error with continued reaction at $300^{\circ} \mathrm{C}$.

The carbonation period at both temperatures is characterized by higher concentrations of $\mathrm{SiO}_{2(a q)}$ and $\mathrm{Mg}$ relative to fluids in the $\mathrm{CO}_{2}$-poor serpentinization stage. Both $\mathrm{SiO}_{2(a q)}$ and $\mathrm{Mg}$ concentrations increased immediately following the $\mathrm{CO}_{2}$ injection, and subsequently decreased. However, concentrations reached significantly higher levels in the $200^{\circ} \mathrm{C}$ experiment, up to 14.7 $\mathrm{mmol} / \mathrm{kg} \mathrm{SiO}{ }_{2(a q)}$ and $8.7 \mathrm{mmol} / \mathrm{kg} \mathrm{Mg}$. Samples 6 and 7 at $200^{\circ} \mathrm{C}$ exhibited highly variable $\mathrm{SiO}_{2(a q)}$ concentrations among individual fluid aliquots of the same sampling event, suggesting that silica may have precipitated during processing of the samples. Therefore, measured $\mathrm{SiO}_{2(a q)}$ concentrations in samples 6 and 7 likely represent minimum values. Dissolved Ca concentrations exhibited very different trends at $200^{\circ} \mathrm{C}$ and $300^{\circ} \mathrm{C}$. In the $200^{\circ} \mathrm{C}$ carbonation experiment, $\mathrm{Ca}$ concentrations increased immediately following the $\mathrm{CO}_{2}$ injection due to addition of a more Carich fluid. Concentrations then showed a significant decrease, before increasing gradually to 8.1 $\mathrm{mmol} / \mathrm{kg}$ with continued reaction. Dissolved $\mathrm{Ca}$ concentrations in the $300^{\circ} \mathrm{C}$ carbonation experiment exhibited an initial increase after the $\mathrm{CO}_{2}$ injection, and subsequently decreased for the remainder of the carbonation period, to a minimum of $3.8 \mathrm{mmol} / \mathrm{kg}$. Dissolved $\mathrm{Na}$ and $\mathrm{Cl}$ concentrations initially decreased at both temperatures due to dilution with the added fluid, which had slightly lower $\mathrm{Na}$ and $\mathrm{Cl}$ concentrations than the fluid in the reaction cell just before the injection. Dissolved $\mathrm{Na}$ and $\mathrm{Cl}$ concentrations remained essentially constant at $300^{\circ} \mathrm{C}$. However, they decreased by $13 \%$ and $9 \%$, respectively, throughout the $200^{\circ} \mathrm{C}$ experiment suggesting there was a slow leakage of water into the reaction cell from the pressurizing fluid. 
Interaction of $\mathrm{a} \mathrm{CO}_{2(a q)}$-rich aqueous fluid with the strongly reducing serpentinization fluid resulted in the formation of dissolved organic species, including formate and methanol (Tables 3.1 and 3.2, Figure 3.4). Total formate concentrations were below the detection limit of ion chromatography prior to the $\mathrm{CO}_{2}$ injection at $200^{\circ} \mathrm{C}$, and remained below the detection limit 7 hours after the injection. Measureable quantities of $\Sigma$ formate were detected 48 hours after the addition of $\mathrm{CO}_{2}$ into the $200^{\circ} \mathrm{C}$ carbonation experiment. Concentrations of $\Sigma$ formate then gradually increased with continued reaction and began to level off at $\sim 1.4 \mathrm{mmol} / \mathrm{kg}$. $\Sigma$ formate concentrations at $300^{\circ} \mathrm{C}$ were also below the detection limit during $\mathrm{CO}_{2}$-poor serpentinization. However, in contrast to the $200^{\circ} \mathrm{C}$ experiment, they attained maximum values immediately following the $\mathrm{CO}_{2}$ injection when $\Sigma \mathrm{CO}_{2(a q)}$ concentrations were highest. $\Sigma$ Formate concentrations then decreased with consumption of $\mathrm{CO}_{2}$, reaching $0.26 \mathrm{mmol} / \mathrm{kg}$ after 3222 hours of reaction. Concentrations of methanol initially decreased after injection of $\mathrm{CO}_{2}$ at $200^{\circ} \mathrm{C}$ and $300^{\circ} \mathrm{C}$, primarily due to dilution with the added fluid. Methanol concentrations were variable but low $(11-15 \mu \mathrm{mol} / \mathrm{kg})$ in the $200^{\circ} \mathrm{C}$ carbonation experiment, and are likely characterized by large errors due to the very low concentrations. In contrast, appreciable quantities of methanol were generated at $300^{\circ} \mathrm{C}$, up to $57 \mu \mathrm{mol} / \mathrm{kg}$.

Injection of a $\mathrm{CO}_{2}$-rich fluid led to broadly similar changes in inorganic fluid chemistries of the $300^{\circ} \mathrm{C}$ experiments described here and in Chapter 2. Addition of $\mathrm{CO}_{2(a q)}$ in both sets of experiments resulted in the production of relatively acidic fluids enriched in dissolved $\mathrm{SiO}_{2}, \mathrm{Mg}$, and $\mathrm{Ca}$ relative to before the $\mathrm{CO}_{2}$ injection. However, fluids in the present $300^{\circ} \mathrm{C}$ experiment contained higher $\mathrm{SiO}_{2(\mathrm{aq})}$ concentrations and lower dissolved $\mathrm{Mg}$ and $\mathrm{Ca}$ concentrations compared to carbonation fluids in Chapter 2. More depleted Ca concentrations observed in the

present experiment mainly reflect the lower $\mathrm{Ca}$ concentration of the starting solution. In addition, while dissolved $\mathrm{H}_{2}$ concentrations remained roughly the same with continued reaction in the present experiment, they showed a strong decrease during mineral carbonation in Chapter 2.

\subsubsection{Petrography of carbonate-altered solids}

Reaction of serpentinized harzburgite and $\mathrm{CO}_{2}$-rich aqueous solution resulted in the formation of carbonate minerals at $200^{\circ} \mathrm{C}$ and $300^{\circ} \mathrm{C}$. Carbonates occur in interstitial pore spaces (Figure 3.5a-b,f-g), in the interiors of completely replaced primary minerals, and as reaction rims surrounding relict primary silicates (Figure 3.5c-d,h-i). Euhedral carbonate crystals were 
observed as suspended particles in the aqueous solution upon termination of each carbonation experiment (Figure 3.5a,f). Carbonates recovered from the $200^{\circ} \mathrm{C}$ experiment were identified as magnesite by SEM/EDS and Raman spectroscopy (Figures 3.5a and 3.6). Magnesite crystals are up to $75 \mu \mathrm{m}$ in diameter and form subhedral dodecahedrons. In contrast, carbonates precipitated at $300^{\circ} \mathrm{C}$ were identified as Ca-rich dolomite by SEM/EDS and Raman spectroscopy (Figures $3.5 \mathrm{f}$ and 3.7). They form larger euhedral crystals, up to $100 \mu \mathrm{m}$ in diameter, with larger individual growth hillocks. Dolomite shows variable Fe-enrichment according to EDS, with more Fe-rich crystals exhibiting pitted surfaces, indicative of partial dissolution.

Carbonate minerals also occur as euhedral crystals in the interstitial pore spaces of carbonate-altered serpentinite formed at $200^{\circ} \mathrm{C}$ and $300^{\circ} \mathrm{C}$ (Figure $3.5 \mathrm{~b}, \mathrm{~g}$ ). Interstitial carbonates typically comprise several compositionally distinct zones. Interstitial carbonates formed at $200^{\circ} \mathrm{C}$ consist of up to 4 discrete zones from core to rim (Figure 3.5b): 1) magnesite, 2) Fe-rich magnesite, 3) magnesite, and 4) Fe-rich magnesite, with Fe-poor areas exhibiting more dissolution pits. The exterior zone additionally shows gradual variation in Fe content, with the rim being less Fe-rich. Interstitial carbonates formed at $300^{\circ} \mathrm{C}$ comprise 3 compositional zones from core to rim (Figure 3.5g): 1) dolomite, 2) magnesite, and 3) dolomite. The exterior zone of dolomite is on average more Ca-rich $\left(55 \pm 5\right.$ mol.\% $\left.\mathrm{CaCO}_{3}\right)$ than the interior zone $(49 \pm 5 \mathrm{~mol} \%$ $\mathrm{CaCO}_{3}$ ), and exhibits gradual variation in $\mathrm{Ca}$ content, with $\mathrm{Ca}$ content decreasing toward the rim. In addition to precipitating homogeneously from solution, carbonate minerals replaced primary silicates at $200^{\circ} \mathrm{C}$ and $300^{\circ} \mathrm{C}$. Ca- and Fe-rich magnesite replaced relict olivine and orthopyroxene in the solids recovered from the $200^{\circ} \mathrm{C}$ carbonation experiment (Figure 3.5c-d). Magnesite forms discontinuous rims, 1-15 $\mu \mathrm{m}$ thick, around relict olivine, and even thicker rims, up to $30 \mu \mathrm{m}$, around relict orthopyroxene. In both cases, magnesite is completely coated with fibrous chrysotile. In the $300^{\circ} \mathrm{C}$ carbonation experiments presented here and in Chapter 2, olivine was the only primary silicate observed to undergo replacement by carbonate minerals, as orthopyroxene was essentially completely altered before the $\mathrm{CO}_{2}$-rich fluid was injected. Relict olivine is surrounded by a discontinuous layer of carbonate minerals, $2-25 \mu \mathrm{m}$ thick, followed by a continuous layer of lizardite \pm magnetite (Figure 3.5h-i). Olivine is similarly altered to carbonate, lizardite, and magnetite in the $300^{\circ} \mathrm{C}$ experiment described in Chapter 2 . However, while dolomite is the only carbonate phase to replace olivine in Chapter 2, dolomite and less commonly magnesite replace olivine in the present experiment. In some instances, both dolomite 
and magnesite are observed to rim the same olivine grain (Figure 3.5i). Magnesite typically appears subhedral and exhibits more dissolution pits compared to dolomite. Where olivine is completely replaced by secondary minerals, carbonate occurs as euhedral to subhedral crystals rimmed by a continuous layer of lizardite \pm magnetite.

Clinopyroxene experienced more significant alteration following the injection of a $\mathrm{CO}_{2}$ rich aqueous fluid. Relict clinopyroxene in the solids recovered form the $200^{\circ} \mathrm{C}$ carbonation experiment exhibits abundant dissolution features, including linear and conical etch pits. However, it appears much less altered than olivine and orthopyroxene, typically being overgrown by a thin, 1-15 $\mu \mathrm{m}$ thick, rim of fibrous chrysotile. A few clinopyroxene grains exhibit more extensive alteration to serpentine minerals (Figure 3.5e). In contrast, clinopyroxene in the $300^{\circ} \mathrm{C}$ carbonation experiment was extensively altered to Fe-rich serpentine \pm magnetite (Figure 3.5j). With the exception of one relict clinopyroxene rimmed by magnesite in the $200^{\circ} \mathrm{C}$ carbonation experiment, no carbonate was observed to replace clinopyroxene at either temperature.

Some Cr-spinel grains in the $200^{\circ} \mathrm{C}$ carbonation experiment exhibit etch pits, indicating they have undergone dissolution. In contrast, $\mathrm{Cr}$-spinel appears unreacted following carbonation at $300^{\circ} \mathrm{C}$. Carbonate-altered solids recovered at $300^{\circ} \mathrm{C}$ contain the secondary sulfides godlevskite and heazlewoodite, as determined by electron microprobe and EDS analyses. Sulfides are 1-12 $\mu \mathrm{m}$ across and are typically associated with magnetite. No analyses of sulfides were obtained from the $200^{\circ} \mathrm{C}$ carbonation experiment.

\subsubsection{Secondary mineral chemistry}

The compositions of secondary minerals formed in the experiments are presented in Tables 3.3 and 3.4. Serpentine formed after clinopyroxene at $300^{\circ} \mathrm{C}$ is significantly richer in $\mathrm{FeO}, \mathrm{Al}_{2} \mathrm{O}_{3}$, and $\mathrm{Cr}_{2} \mathrm{O}_{3}$ relative to serpentine formed after olivine and orthopyroxene. Serpentine after clinopyroxene has $\mathrm{Mg} \# \mathrm{~s}$ of 80.5-86.1, $\mathrm{Al}_{2} \mathrm{O}_{3}$ contents of 6.4-8.5 wt.\%, and $\mathrm{Cr}_{2} \mathrm{O}_{3}$ contents of 3.1-4.4 wt.\%.

Dolomite replacing olivine in the $300^{\circ} \mathrm{C}$ carbonation experiment contains $56.4 \pm 3.0$ mol. $\% \mathrm{CaCO}_{3}$, and is enriched in Ca relative to its ideal end-member composition. It has a significant Fe component, with an average $\mathrm{Mg} \#$ of $88.0 \pm 1.0$. Dolomite precipitated in interstitial spaces shows highly variable $\mathrm{Ca}$ contents, and exhibits both $\mathrm{Ca}$ depletions and 
enrichments relative to its stoichiometric formula. Dolomite rims are on average more $\mathrm{Ca}$ - and Fe-rich $\left(55.4 \pm 5.1 \mathrm{~mol} . \% \mathrm{CaCO}_{3}, \mathrm{Mg} \# 88.5 \pm 1.7\right)$ relative to dolomite interiors $(48.8 \pm 4.5$ mol. $\left.\% \mathrm{CaCO}_{3}, \mathrm{Mg} \# 93.9 \pm 1.9\right)$. The composition of dolomite formed during carbonation of serpentinized harzburgite at $300^{\circ} \mathrm{C}$ is consistent with dolomite chemistries documented in Chapter 2. Raman spectra exhibit shifts in the $\mathrm{CO}_{3}$ band positions to lower wavenumbers (Figure 3.7), indicative of Ca substitution into the dolomite structure. Magnesite replacing olivine is enriched in $\mathrm{Ca}$ and $\mathrm{Fe}$ relative to its end-member composition, with an average $\mathrm{CaCO}_{3}$ component of $7.1 \pm 0.6 \mathrm{~mol} \%$ and an average $\mathrm{Mg \#}$ of $92.8 \pm 0.9$. Magnesite in interstitial pore spaces exhibits similar $\mathrm{Ca}$ enrichments $\left(7.4 \pm 0.8 \mathrm{~mol} . \% \mathrm{CaCO}_{3}\right)$, but is slightly more Fe-poor $(\mathrm{Mg} \# 94.5 \pm 0.8)$.

Carbonate minerals formed at $200^{\circ} \mathrm{C}$ were difficult to analyze by EMPA due to their small size. The few carbonate analyses obtained from the $200^{\circ} \mathrm{C}$ carbonation experiment indicate that magnesite is $\mathrm{Ca}$ - and $\mathrm{Fe}$-rich, with $\mathrm{C} \mathrm{CaCO}_{3}$ component of 8.9-23.9 mol.\% and $\mathrm{Mg \#} \mathrm{of} \mathrm{80.9-}$ 88.9. Measured $\mathrm{Ca}$ contents are significantly higher than those reported for naturally occurring magnesite (e.g., Dabitzias, 1980; Boschi et al., 2009; Beinlich et al., 2012; Oskierski et al., 2013). Previous experiments investigating the hydrothermal alteration of Ca-carbonates to magnesite have documented the formation of magnesite with $\mathrm{MgCO}_{3}$ contents as low as 80-87 mol.\% (Jonas et al., 2015; Kell-Duivestein et al., 2017), consistent with values measured in the present study on an Fe-free basis. Alternatively, high Ca contents may result from the fine intergrowth of magnesite with dolomite that cannot be clearly resolved with EMPA or Raman spectroscopy. Electron microprobe analysis of one interstitial carbonate in the $200^{\circ} \mathrm{C}$ carbonation experiment provides tentative identification of dolomite. However, no dolomite was detected in the alteration solids by Raman spectroscopy.

\subsubsection{Bulk physical and chemical properties}

Bulk chemical compositions of the solid alteration products are presented in Table 3.5. Injection of $\mathrm{a} \mathrm{CO}_{2(a q)}$-rich fluid into serpentinized harzburgite resulted in an increase in loss on ignition due to the formation of more carbonate and serpentine minerals, with values increasing from $6.60 \mathrm{wt} . \%$ to $8.38 \mathrm{wt} . \%$ in the $200^{\circ} \mathrm{C}$ experiments, and from $11.99 \mathrm{wt} . \%$ to $13.59 \mathrm{wt} . \%$ in the $300^{\circ} \mathrm{C}$ experiments. Despite the change in mineralogy, bulk density remained essentially constant following reaction with a $\mathrm{CO}_{2}$-rich fluid. Bulk density decreased only slightly from 2.98 
to $2.97 \mathrm{~g} / \mathrm{cm}^{3}$ at $200^{\circ} \mathrm{C}$, and from 2.72 to $2.71 \mathrm{~g} / \mathrm{cm}^{3}$ at $300^{\circ} \mathrm{C}$. Reaction of $\mathrm{CO}_{2}$ and serpentinized harzburgite yielded lower $\mathrm{Fe}^{3+} / \Sigma \mathrm{Fe}$ due to uptake of $\mathrm{Fe}^{2+}$ by carbonate minerals. $\mathrm{Fe}^{3+} / \Sigma \mathrm{Fe}$ decreased slightly from 0.26 to 0.24 in the $200^{\circ} \mathrm{C}$ experiments, and more significantly from 0.56 to 0.45 in the $300^{\circ} \mathrm{C}$ experiments. Volume-specific magnetic susceptibility increased to some extent during carbonation at $200^{\circ} \mathrm{C}$ and $300^{\circ} \mathrm{C}$, to $5.71 \times 10^{-4}$ S.I. and $1.93 \times 10^{-2}$ S.I., respectively.

Solid products from the $200^{\circ} \mathrm{C}$ carbonation experiment have a bulk inorganic carbon content of $0.32 \mathrm{wt} . \%$, corresponding to a magnesite content of $2.28 \mathrm{wt} . \%$. Significantly more carbonate minerals formed at higher temperature. Carbonate-altered solids recovered at $300^{\circ} \mathrm{C}$ have a bulk inorganic carbon content of $1.00 \mathrm{wt}$ \%, corresponding to a dolomite content of 7.69 wt.\%.

\section{DISCUSSION}

\subsection{Reaction pathways during $\mathrm{CO}_{2}$-poor serpentinization}

Petrographic observations indicate that hydrothermal alteration of olivine and orthopyroxene proceeded according to the following reactions in the $\mathrm{MgO}-\mathrm{SiO}_{2}-\mathrm{H}_{2} \mathrm{O}$ system:

$$
\begin{aligned}
& \underset{\text { olivine }}{2 \mathrm{Mg}_{2} \mathrm{SiO}_{4}}+3 \mathrm{H}_{2} \mathrm{O}=\underset{\text { serpentine }}{\mathrm{Mg}_{3} \mathrm{Si}_{2} \mathrm{O}_{5}(\mathrm{OH})_{4}}+\underset{\text { brucite }}{\mathrm{Mg}(\mathrm{OH})_{2}} \\
& \underset{\mathrm{Mg}_{2} \mathrm{Si}_{2} \mathrm{O}_{6}+4 \mathrm{H}_{2} \mathrm{O}=\underset{\text { orthopyroxene }}{2}}{2 \mathrm{Mg}_{3} \mathrm{Si}_{2} \mathrm{O}_{5}(\mathrm{OH})_{4}}+2 \mathrm{SiO}_{2(a q)} \\
& \text { serpentine }
\end{aligned}
$$

Serpentinization at $300^{\circ} \mathrm{C}$ resulted in the near complete consumption of orthopyroxene according to reaction 2, and an overall greater extent of reaction, consistent with faster reaction kinetics at higher temperatures (Martin and Fyfe, 1970; Janecky and Seyfried, 1986).

Reaction pathways during serpentinization were further assessed by speciating fluid compositions at in situ temperatures and pressures (Figure 3.8). Calculated in situ $\mathrm{SiO}_{2(a q)}$ activities $\left(a \mathrm{SiO}_{2(a q)}\right)$ of fluids in the early stages of $\mathrm{CO}_{2}$-poor serpentinization at all temperatures fall within the range of $a \mathrm{SiO}_{2(a q)}$ for which chrysotile is stable (Figure 3.8a-d). Dissolved $\mathrm{SiO}_{2}$ concentrations were initially elevated in the first fluids sampled at $200^{\circ} \mathrm{C}$ and $300^{\circ} \mathrm{C}$, but 
subsequently decreased with continued reaction. Values of $a \mathrm{SiO}_{2(a q)}$ at $200^{\circ} \mathrm{C}$ appear to reach brucite-chrysotile equilibrium after 3881 hours of reaction (Figure 3.8a,c), consistent with the presence of brucite and serpentine minerals in the alteration solids. This indicates that brucite and serpentine attained equilibrium with one another by the end of the $200^{\circ} \mathrm{C}$ experiment, according to the generalized reaction:

$3 \mathrm{Mg}(\mathrm{OH})_{2}+2 \mathrm{SiO}_{2(a q)}=\mathrm{Mg}_{3} \mathrm{Si}_{2} \mathrm{O}_{5}(\mathrm{OH})_{4}+\mathrm{H}_{2} \mathrm{O}$

brucite serpentine

where brucite and serpentine represent $\mathrm{Mg}$ endmember components of solid solutions.

$\mathrm{SiO}_{2(a q)}$ activities at $300^{\circ} \mathrm{C}$, in contrast, were $\sim 1$ order of magnitude higher than those at $200^{\circ} \mathrm{C}$ for comparable reaction times, and remained well above brucite-chrysotile equilibrium values, despite longer reaction times and the presence of brucite in the solid products (Figure $3.8 \mathrm{~b}, \mathrm{~d})$. Lower $\mathrm{SiO}_{2(a q)}$ activities at $200^{\circ} \mathrm{C}$ likely reflect slow rates of orthopyroxene dissolution relative to olivine dissolution at temperatures $<300^{\circ} \mathrm{C}$ (Martin and Fyfe, 1970; Janecky and Seyfried, 1986; Seyfried et al., 2007; Okamoto et al., 2011). Indeed, abundant orthopyroxene remained at the end of the $200^{\circ} \mathrm{C}$ serpentinization experiment. In contrast, little orthopyroxene remained following $\mathrm{CO}_{2}$-poor serpentinization at $300^{\circ} \mathrm{C}$, consistent with faster dissolution rates of orthopyroxene relative to olivine at temperatures $\geq 300^{\circ} \mathrm{C}$ (Martin and Fyfe, 1970; Janecky and Seyfried, 1986; Allen and Seyfried, 2003). $\mathrm{SiO}_{2(a q)}$ released by orthopyroxene dissolution at $300^{\circ} \mathrm{C}$ should react with brucite to form serpentine and lower $\mathrm{SiO}_{2(a q)}$ activities according to reaction 3. However, high $a \mathrm{SiO}_{2(a q)}$ values at $300^{\circ} \mathrm{C}$ indicate that kinetic inhibitions prevented brucite from attaining equilibrium with serpentine on the timescale of the experiment. Similar kinetic inhibitions to brucite-serpentine equilibrium have been reported for the hydrothermal alteration of olivine at $200-320^{\circ} \mathrm{C}$ (McCollom et al., 2016). In contrast to the $300^{\circ} \mathrm{C}$ experiment presented here, fluids in the Chapter 2 experiment reached equilibrium with brucite and serpentine by the end of the $\mathrm{CO}_{2}$-poor serpentinization stage (Figure 2.9a). Attainment of brucite-serpentine equilibrium most likely resulted from the longer duration of the Chapter 2 experiment (14569 hours) compared to the $300^{\circ} \mathrm{C}$ experiment in the present study (5189 hours), since fluids in both experiments reached similar $\mathrm{SiO}_{2(a q)}$ activities after comparable reaction 
times. We would, therefore, expect $\mathrm{SiO}_{2(a q)}$ activities in the $300^{\circ} \mathrm{C}$ experiments described here to also reach brucite-serpentine equilibrium given sufficient reaction time.

Low dissolved $\mathrm{Mg}$ activities indicate that calcite was the stable carbonate phase during $\mathrm{CO}_{2}$-poor serpentinization at all temperatures (Figure 3.8e,f), consistent with the presence of minor calcite in the alteration products. Small amounts of inorganic carbon required for calcite formation was likely sourced from the harzburgite protolith or atmospheric $\mathrm{CO}_{2}$ in the starting solution, since no carbon source was initially added to the system. Precipitation of calcite likely took up some dissolved $\mathrm{Ca}$ from solution in both the $200^{\circ} \mathrm{C}$ and $300^{\circ} \mathrm{C}$ experiments. However, the minor amount of calcite estimated to precipitate from background levels of $\mathrm{CO}_{2(a q)}$ in the fluids $(<0.2 \mathrm{mmol} / \mathrm{kg}$ ) is not sufficient to explain the large decrease in dissolved $\mathrm{Ca}$ concentrations, from $9.6 \mathrm{mmol} / \mathrm{kg}$ in the starting solution to a minimum of $5.4 \mathrm{mmol} / \mathrm{kg}$ and 2.4 $\mathrm{mmol} / \mathrm{kg}$ at $200^{\circ} \mathrm{C}$ and $300^{\circ} \mathrm{C}$, respectively. The observed decrease in Ca concentrations during serpentinization may, instead, be due to precipitation of secondary clinopyroxene and/or precipitation of a portlandite component in brucite $\left[\mathrm{Ca}(\mathrm{OH})_{2}\right]$.

\subsection{1. $\mathrm{H}_{2}$ generation and Fe partitioning}

Significant amounts of dissolved $\mathrm{H}_{2}$ were generated by oxidation of $\mathrm{Fe}^{2+}$ in the primary minerals, olivine and orthopyroxene, to $\mathrm{Fe}^{3+}$ in the secondary minerals, serpentine \pm magnetite. Alteration of harzburgite at $200^{\circ} \mathrm{C}$ led to the formation of serpentine as the sole $\mathrm{Fe}^{3+}$-bearing secondary mineral. This resulted in a lower bulk $\mathrm{Fe}^{3+} / \Sigma \mathrm{Fe}$ ratio of the alteration solids, and consequently, lower $\mathrm{H}_{2(a q)}$ concentrations (up to $38 \mathrm{mmol} / \mathrm{kg}$ ) relative to serpentinization at $300^{\circ} \mathrm{C}$. The presence of minor pyrite in the $200^{\circ} \mathrm{C}$ experiment is consistent with less reducing conditions as indicated by Fe-Ni-O-S phase relations (Frost, 1985; Klein and Bach, 2009). Serpentinization at $300^{\circ} \mathrm{C}$ resulted in a greater extent of oxidation and the formation of magnetite in addition to serpentine minerals, producing a higher bulk $\mathrm{Fe}^{3+} / \Sigma \mathrm{Fe}$ ratio and higher dissolved $\mathrm{H}_{2}$ concentrations (up to $106 \mathrm{mmol} / \mathrm{kg}$ ). The presence of minor heazlewoodite and awaruite in the alteration solids is consistent with the production of more reducing fluids at $300^{\circ} \mathrm{C}$ (Frost, 1985; Klein and Bach, 2009).

Serpentine minerals produced by alteration of olivine and orthopyroxene during $\mathrm{CO}_{2-}$ poor serpentinization contain an appreciable Fe component ( $\mathrm{Mg} \#$ 90-93). Based on the limited number of analyses obtained for serpentine at $200^{\circ} \mathrm{C}$, there does not appear to be any significant 
variation in Fe content with temperature. Relatively uniform serpentine compositions at 200$300^{\circ} \mathrm{C}$ are consistent with previous laboratory experiments involving hydrothermal alteration of olivine (Malvoisin et al., 2012; McCollom et al., 2016) and thermodynamic models of serpentinization at $200-300^{\circ} \mathrm{C}$ (Klein et al., 2009; McCollom and Bach, 2009; Klein et al., 2013). Brucite produced at $300^{\circ} \mathrm{C}$ is somewhat more Fe-rich ( $\mathrm{Mg} \#$ 87-89) than co-precipitating serpentine (Mg\# 90-93). Similar Fe distributions in brucite-serpentine mineral pairs have been reported in previous serpentinization experiments conducted at the same temperature (Malvoisin et al., 2012; McCollom et al., 2016). Although no measurements could be obtained of brucite formed in the $200^{\circ} \mathrm{C}$ experiment, thermodynamic models predict that the Fe content of brucite should increase with decreasing temperature as less magnetite is produced (Klein et al., 2009; McCollom and Bach, 2009; Klein et al., 2013).

\subsection{Reaction pathways during peridotite- $\mathrm{CO}_{2}$ interactions}

Injection of a $\mathrm{CO}_{2}$-rich fluid into actively serpentinizing harzburgite resulted in large and rapid changes in fluid chemistry (Tables 3.1 and 3.2; Figure 3.2). Within several hours of the injection, in situ $\mathrm{pH}$ decreased from 8.5 to 4.8 at $200^{\circ} \mathrm{C}$ and from 7.6 to 5.2 at $300^{\circ} \mathrm{C}$. Speciation calculations suggest that brucite, olivine, orthopyroxene, and clinopyroxene were unstable under these conditions (Figure 3.8). A lower $\mathrm{pH}$ promoted the dissolution of brucite and primary silicates present at the end of the $\mathrm{CO}_{2}$-poor serpentinization period, as indicated by decreasing proportions of these minerals in the alteration products following carbonation. Dissolved $\mathrm{Mg}$ and $\mathrm{SiO}_{2}$ concentrations increased markedly at all temperatures, consistent with enhanced mineral dissolution.

$\mathrm{SiO}_{2(a q)}$ activities reached high enough values in the first $\sim 200$ hours of reaction at $300^{\circ} \mathrm{C}$ to stabilize talc. Speciated compositions of the first three fluids sampled after the $\mathrm{CO}_{2}$ injection plot near the chrysotile-talc equilibrium boundary (samples 6-8 in Figure 3.8b,d). However, no talc was identified in the alteration solids by optical, Raman, or electron microprobe analyses. Lack of talc in the reaction products may reflect relatively slow precipitation kinetics (Saccocia et al., 2009), low levels of super-saturation, and/or dissolution of talc prior to termination of the experiment. Concentrations of dissolved $\mathrm{SiO}_{2}$ were even higher during carbonation at $200^{\circ} \mathrm{C}$, with bulk fluids attaining concentrations at or above quartz saturation 7 hours after the $\mathrm{CO}_{2}$ injection (sample 5 in Figure 3.8c). However, quartz was not observed in the alteration solids, 
likely due to sluggish precipitation rates (samples 6-9 in Figure 3.8c). $\mathrm{SiO}_{2(a q)}$ concentrations subsequently decreased at all temperatures as serpentine minerals formed after clinopyroxene (Figure 3.5e-j).

Significantly higher concentrations of dissolved $\mathrm{SiO}_{2}$ and $\mathrm{Mg}$ at $200^{\circ} \mathrm{C}$ relative to $300^{\circ} \mathrm{C}$ likely reflect the higher proportion of reactive primary silicates remaining at the end of $\mathrm{CO}_{2}$-poor serpentinization, as well as the sequestration of $\mathrm{Mg}$ and $\mathrm{SiO}_{2}$ in unreactive serpentine minerals at $300^{\circ} \mathrm{C}$. Serpentinization of harzburgite at $200^{\circ} \mathrm{C}$ produced a rock composed of $\sim 32 \mathrm{vol} . \%$ primary olivine and pyroxene minerals. In contrast, only $\sim 6 \%$ vol. $\%$ of primary minerals remained following more extensive serpentinization at $300^{\circ} \mathrm{C}$, and nearly all of orthopyroxene was consumed. Serpentine minerals appear unaltered in all experiments, suggesting they were unreactive during carbonation and did not contribute $\mathrm{Mg}$ and $\mathrm{SiO}_{2}$ to solution. This is consistent with rates of serpentine carbonation that are orders of magnitude slower than carbonation rates of brucite, olivine, and pyroxene under hydrothermal conditions (Gerdemann et al., 2007; Kelemen et al., 2011; Hövelmann et al., 2011; Daval et al., 2013). A higher degree of serpentinization in stage 1 of the $300^{\circ} \mathrm{C}$ experiment resulted in more $\mathrm{Mg}$ and $\mathrm{SiO}_{2}$ being sequestered into unreactive serpentine minerals and thus unavailable for secondary mineral formation.

Following the injection of a $\mathrm{CO}_{2(a q)}$-rich fluid, dissolved $\mathrm{H}_{2}$ concentrations at both temperatures decreased more than can be accounted for by dilution with the added fluid and by potential loss of $\mathrm{H}_{2}$ due to leakage of the hydrothermal reactor. The slow leakage detected at $200^{\circ} \mathrm{C}$ (experiment $\# 2$ ) may have decreased $\mathrm{H}_{2 \text { (aq) }}$ concentrations by at most $\sim 2.5 \mathrm{mmol} / \mathrm{kg}$ as determined from the decrease in dissolved $\mathrm{Na}$ and $\mathrm{Cl}$ concentrations over the same time period. Similar $\mathrm{H}_{2}$ depletions have been documented in Chapter 2 and in previous laboratory experiments investigating mineral carbonation in active serpentinization systems (Klein and McCollom, 2013). $\mathrm{H}_{2}$ may have been consumed by formation of reduced carbon intermediaries (e.g., formate, methanol) and/or reduction of $\mathrm{Fe}^{3+}$ to $\mathrm{Fe}^{2+}$ in the siderite component of carbonate minerals. Destruction of magnetite at $300^{\circ} \mathrm{C}$ may have provided Fe for siderite formation, according to the reaction:

$\mathrm{Fe}_{3} \mathrm{O}_{4}+3 \mathrm{CO}_{2(a q)}+\mathrm{H}_{2(a q)}=3 \mathrm{FeCO}_{3}+\mathrm{H}_{2} \mathrm{O}$ 
However, no detectable magnetite was present in the $200^{\circ} \mathrm{C}$ experiments to act as a source of

$\mathrm{Fe}^{3+}$. In addition, serpentine minerals formed during the initial $\mathrm{CO}_{2}$-poor stage of the experiment appear unreacted and, thus, were unlikely to have contributed Fe for carbonate formation.

\subsubsection{Formation of carbonate minerals}

Dissolution of Mg-bearing minerals after injection of a $\mathrm{CO}_{2(a q)}$-rich fluid increased the $\mathrm{Mg} / \mathrm{Ca}$ ratio in solution from near zero at the end of the $\mathrm{CO}_{2}$-poor serpentinization stages to 0.22 and 1.10 at $200^{\circ} \mathrm{C}$ and $300^{\circ} \mathrm{C}$, respectively (Tables 3.1 and 3.2). The increase in dissolved $\mathrm{Mg}$ activities destabilized early-formed calcite in favor of Mg-bearing carbonate minerals at both temperatures (Figure 3.8e-f). Magnesite was the only carbonate mineral to precipitate in the $200^{\circ} \mathrm{C}$ experiment, although there are tentative indications for the formation of trace dolomite. Both dolomite and minor magnesite precipitated during carbonation at $300^{\circ} \mathrm{C}$. In contrast to the experiments described here, the experiment in Chapter 2 did not produce any magnesite. This is likely due to the higher dissolved $\mathrm{Ca}$ concentration $(31 \mathrm{mmol} / \mathrm{kg})$ in the starting solution, which resulted in fluids with lower $\mathrm{Mg} / \mathrm{Ca}$ ratios. Whereas $\mathrm{Mg} / \mathrm{Ca}$ fluid ratios in the present experiments reached maximum values of 3.50 and 0.29 following the addition of $\mathrm{CO}_{2}$ at $200^{\circ} \mathrm{C}$ and $300^{\circ} \mathrm{C}$, respectively, $\mathrm{Mg} / \mathrm{Ca}$ ratios increased to only 0.21 in the Chapter 2 experiment. Lower $\mathrm{Mg} / \mathrm{Ca}$ fluid ratios in Chapter 2 may also reflect a higher extent of reaction during the initial $\mathrm{CO}_{2}$-poor serpentinization stage. A greater degree of serpentinization would sequester more $\mathrm{Mg}$ in unreactive serpentine minerals and limit the release of $\mathrm{Mg}$ from mineral dissolution. However, the extent of serpentinization in the Chapter 2 experiment could not be confirmed as the alteration solids were not examined before the $\mathrm{CO}_{2}$ injection.

We propose that the main factor influencing carbonate mineralogy following $\mathrm{CO}_{2}$ injection in the present experiments is the extent of prior rock alteration during $\mathrm{CO}_{2}$-poor serpentinization. A greater degree of serpentinization at $300^{\circ} \mathrm{C}$ led to more $\mathrm{Mg}$ being sequestered in unreactive serpentine minerals as discussed above, limiting the availability of $\mathrm{Mg}$ for subsequent carbonate formation. In contrast, a higher proportion of more reactive primary silicates remained at the end of $\mathrm{CO}_{2}$-poor serpentinization at $200^{\circ} \mathrm{C}$. Dissolution of primary olivine and orthopyroxene following injection of $\mathrm{CO}_{2}$ at $200^{\circ} \mathrm{C}$ generated significantly higher dissolved $\mathrm{Mg}$ concentrations and higher $\mathrm{Mg} / \mathrm{Ca}$ activity ratios, thereby stabilizing magnesite at $200^{\circ} \mathrm{C}$. 
Lack of brucite in the alteration solids recovered from each carbonation experiment suggests that brucite underwent carbonation at 200 and $300^{\circ} \mathrm{C}$ according to the reaction:

$\mathrm{Mg}(\mathrm{OH})_{2}+\mathrm{CO}_{2(a q)}=\mathrm{MgCO}_{3}+\mathrm{H}_{2} \mathrm{O}$

brucite magnesite

and at $300^{\circ} \mathrm{C}$ by the reaction:

$\mathrm{Mg}(\mathrm{OH})_{2}+2 \mathrm{CO}_{2(a q)}+\mathrm{Ca}^{2+}=\mathrm{CaMg}\left(\mathrm{CO}_{3}\right)_{2}+2 \mathrm{H}^{+}$

brucite dolomite

Experiments by Zhao et al. (2010) and Harrison et al. (2013) have demonstrated that brucite carbonation to magnesite is rapid at ambient temperature and moderate $\mathrm{P}_{\mathrm{CO}_{2}}$, and can lead to complete conversion on timescales of hours to tens of hours. The initial rapid decrease in $\Sigma \mathrm{CO}_{2 \text { (aq) }}$ concentrations following $\mathrm{CO}_{2}$ injection is consistent with fast carbonation kinetics for brucite.

The occurrence of carbonate rims over olivine and orthopyroxene suggests that carbonate minerals replaced these primary silicates via dissolution-precipitation reactions, such as:

$200^{\circ} \mathrm{C}$ only:

$\mathrm{Mg}_{2}\left(\mathrm{SiO}_{3}\right)_{2}+2 \mathrm{CO}_{2(a q)}=2 \mathrm{MgCO}_{3}+2 \mathrm{SiO}_{2(a q)}$

orthopyroxene magnesite

$200^{\circ} \mathrm{C}$ and $300^{\circ} \mathrm{C}$ :

$\mathrm{Mg}_{2} \mathrm{SiO}_{4}+2 \mathrm{CO}_{2(a q)}=2 \mathrm{MgCO}_{3}+\mathrm{SiO}_{2(a q)}$

olivine magnesite

$300^{\circ} \mathrm{C}$ only:

$\mathrm{Mg}_{2} \mathrm{SiO}_{4}+4 \mathrm{CO}_{2(a q)}+2 \mathrm{Ca}^{2+}+2 \mathrm{H}_{2} \mathrm{O}=2 \mathrm{CaMg}\left(\mathrm{CO}_{3}\right)_{2}+\mathrm{SiO}_{2(a q)}+4 \mathrm{H}^{+}$ olivine dolomite 
Carbonation of olivine and orthopyroxene is known to proceed more slowly than that of brucite at elevated temperatures and pressures (Kelemen et al., 2011), resulting in the incomplete reaction of primary silicates during the carbonation experiments. Thin section image analysis revealed that reaction of serpentinized harzburgite with a $\mathrm{CO}_{2}$-rich fluid decreased the proportion of primary silicates in the alteration solids from $\sim 32$ to 25 vol. $\%$ at $200^{\circ} \mathrm{C}$, and from $\sim 6$ to 5 vol. $\%$ at $300^{\circ} \mathrm{C}$. Consumption of primary silicates reflects both replacement of olivine \pm orthopyroxene by carbonate minerals and alteration of clinopyroxene to serpentine. Since clinopyroxene experienced a relatively low degree of alteration at $200^{\circ} \mathrm{C}$ (Figure $3.5 \mathrm{e}$ ), most of the depletion in primary silicates at this temperature can be attributed to carbonate replacement. More extensive consumption of primary silicates at $200^{\circ} \mathrm{C}(\sim 7 \mathrm{vol} . \%)$ relative to $300^{\circ} \mathrm{C}(\sim 1$ vol.\%) suggests that carbonation rates were more rapid at lower temperatures. This is consistent with previous studies of olivine carbonation which have demonstrated that carbonation rates are fastest at $\sim 185^{\circ} \mathrm{C}$ and decrease at higher temperatures (O'Connor et al., 2005; Gerdemann et al., 2007). This optimal temperature reflects competing drives between kinetics and thermodynamics (Kelemen and Matter, 2008). Although higher temperatures increase diffusion rates, they lower the chemical potential gradient that provides the thermodynamic driving force for carbonation (Klein and Garrido, 2011).

While fewer silicate minerals were consumed during carbonation at $300^{\circ} \mathrm{C}$, more carbonate minerals formed at this temperature as indicated by the higher bulk inorganic carbon content of the alteration solids. Carbonate-altered solids recovered at $200^{\circ} \mathrm{C}$ and $300^{\circ} \mathrm{C}$ have bulk inorganic carbon contents of $0.32 \mathrm{wt} . \%$ and $1.00 \mathrm{wt.} \%$, respectively. The larger quantity of carbonate minerals produced at $300^{\circ} \mathrm{C}$ likely reflects more extensive carbonate replacement of brucite and homogeneous precipitation. A higher proportion of brucite is expected to be present prior to the $\mathrm{CO}_{2}$ injection at $300^{\circ} \mathrm{C}$, as harzburgite experienced a higher degree of serpentinization at this temperature. In addition, more $\mathrm{CO}_{2}$ was added to the $300^{\circ} \mathrm{C}$ experiment, which should result in more extensive carbonate precipitation.

Carbonate minerals precipitated in interstitial pore spaces are typically compositionally zoned and reflect changes in fluid chemistry during carbonation. Interstitial magnesite precipitated at $200^{\circ} \mathrm{C}$ exhibits zonation predominantly in Fe-content as revealed by SEM/EDS and electron microprobe analyses, with magnesite exteriors generally being more Fe-rich than interiors (Figure 3.5b and Table 3.3). Magnesite precipitated at $200^{\circ} \mathrm{C}$ is also enriched in $\mathrm{Fe}$ 
compared to carbonate minerals formed at $300^{\circ} \mathrm{C}$. Fe enrichment may reflect replacement of brucite, which is predicted to be more Fe-rich at $200^{\circ} \mathrm{C}$. However, no analyses were performed on brucite in the $200^{\circ} \mathrm{C}$ experiments due to the small grain size of the minerals. Interstitial carbonates formed at $300^{\circ} \mathrm{C}$, in comparison, exhibit more striking compositional zonation (Figure $3.5 \mathrm{~g}$ and Table 3.4). Carbonate interiors are typically composed of dolomite overgrown by magnesite. Carbonate exteriors comprise Ca-rich dolomite that exhibits gradual depletion in $\mathrm{Ca}$ towards the rim. The observed zonation in carbonate mineralogy likely reflects changes in the $\mathrm{Mg} / \mathrm{Ca}$ ratio in solution during carbonation. Prior to the injection of a $\mathrm{CO}_{2}$-rich fluid, the $\mathrm{Mg} / \mathrm{Ca}$ ratio of the bulk fluid was close to zero. Addition of $\mathrm{CO}_{2(\mathrm{aq})}$ resulted in the rapid dissolution of brucite that released $\mathrm{Mg}$ into solution and increased the $\mathrm{Mg} / \mathrm{Ca}$ ratio of the fluid sufficiently to stabilize dolomite. Therefore, dolomite is the first Mg-bearing carbonate predicted to form. However, it is conceivable that dissolution of brucite increased $\mathrm{Mg} / \mathrm{Ca}$ ratios to much higher values than measured in the first sample after the injection (sample 6). The middle zone of magnesite may have, therefore, formed prior to sample 6 if $\mathrm{Mg} / \mathrm{Ca}$ ratios increased to values significantly higher than 0.22 . Continued precipitation of magnesite would subsequently take up dissolved $\mathrm{Mg}$, lowering the $\mathrm{Mg} / \mathrm{Ca}$ ratio in solution and bringing the fluid back into the stability field of dolomite (samples 6-8). Formation of more Mg-rich dolomite was favored in the later stages of carbonation as slower carbonation of olivine took up Ca from solution and increased the $\mathrm{Mg} / \mathrm{Ca}$ ratio of the fluid over time (samples 8-11).

\subsubsection{Formation of reduced carbon species}

Serpentinization of harzburgite at $200-300^{\circ} \mathrm{C}$ generated strongly reducing conditions that favor the reduction of $\mathrm{CO}_{2}$ to reduced carbon species, including formate, methanol, and $\mathrm{CH}_{4(a q)}$. The extent to which these reduced carbon species attained thermodynamic equilibrium in the experiments can be assessed by calculating the chemical affinity, $A$, for each reaction using the relation:

$A=-\Delta_{r} G=-R T \ln \left(Q_{r} K_{e q}\right)$

where $R$ is the universal gas constant, $T$ is the temperature in Kelvin, $Q_{r}$ is the reaction quotient, and $K_{e q}$ is the equilibrium constant for the reaction. The chemical affinity of $\mathrm{CO}_{2(a q)}$ reduction to 
$\mathrm{CH}_{4(a q)}$ is calculated to be large in the first fluid sampled after the $\mathrm{CO}_{2}$ injection $(A=145 \mathrm{KJ} / \mathrm{mol}$ at $200^{\circ} \mathrm{C}$, and $117 \mathrm{KJ} / \mathrm{mol}$ at $300^{\circ} \mathrm{C}$ ). Dissolved $\mathrm{CH}_{4}$ was generated during both $\mathrm{CO}_{2}$-poor serpentinization and subsequent carbonation of harzburgite, and reached concentrations of up to $16 \mu \mathrm{mol} / \mathrm{kg}$ at $200^{\circ} \mathrm{C}$ and $59 \mu \mathrm{mol} / \mathrm{kg}$ at $300^{\circ} \mathrm{C}$ (Tables 3.1 and 3.2, Figure 3.2). However, such low concentrations are likely not a product of $\mathrm{CO}_{2}$ reduction to $\mathrm{CH}_{4}$, but are more likely sourced from trace amounts of reduced carbon in the starting material. Indeed, previous serpentinization experiments have reported the production of micromolar quantities of $\mathrm{CH}_{4(a q)}$ from organic impurities in olivine (McCollom and Seewald, 2001; McCollom and Seewald, 2007). In addition, injection of $\mathrm{a} \mathrm{CO}_{2}$-rich fluid did not appear to appreciably increase the rate of $\mathrm{CH}_{4}$ production, as would be expected if $\mathrm{CH}_{4}$ were derived from the reduction of $\mathrm{CO}_{2}$. Instead, dissolved $\mathrm{CH}_{4}$ concentrations remained low throughout carbonation, despite the strong thermodynamic drive for $\mathrm{CH}_{4}$ formation. These results are consistent with strong kinetic barriers to $\mathrm{CO}_{2}$ reduction to $\mathrm{CH}_{4}$ under hydrothermal conditions, except in the presence of specific catalysts (Chapter 2; McCollom and Seewald, 2001; McCollom and Seewald, 2003; Foustoukos and Seyfried, 2004; Seewald et al., 2006; Fu et al., 2007; McCollom, 2016).

Concentrations of total formate were below the detection limit during $\mathrm{CO}_{2}$-poor serpentinization of harzburgite. Subsequent addition of $\mathrm{CO}_{2(a q)}$ resulted in the formation of mmolar quantities of $\Sigma$ formate at $200^{\circ} \mathrm{C}$ and $300^{\circ} \mathrm{C}$ (Tables 3.1 and 3.2, Figure 3.4), according to the reaction:

$\mathrm{CO}_{2(\mathrm{aq})}+\mathrm{H}_{2(\mathrm{aq})}=\mathrm{HCOOH}$

Thermodynamic calculations were performed to determine whether equilibrium was attained among dissolved carbon species in the system. Comparison of measured and equilibrium $\Sigma$ formate concentrations indicates that reduction of $\mathrm{CO}_{2(a q)}$ to formate was sufficiently rapid at $300^{\circ} \mathrm{C}$ to establish a state of metastable thermodynamic equilibrium between these species within 8 hours of $\mathrm{CO}_{2}$ injection (Figure 3.4b). These results are consistent with the rapid reduction of $\mathrm{CO}_{2(a q)}$ to formate previously documented at $300^{\circ} \mathrm{C}$, with $\mathrm{CO}_{2}$-formate equilibrium attained in less than 48 hours (McCollom and Seewald, 2001; Seewald et al., 2006). Equilibrium $\Sigma$ formate concentrations are slightly higher than measured values, which may reflect uncertainties in the calculated in situ $\mathrm{pH}$ of the experiments. If total thermodynamic equilibrium 
were obtained, then the majority of $\mathrm{CO}_{2(a q)}$ should have been converted to $\mathrm{CH}_{4(a q)}$ at the experimental conditions. However, measured concentrations of $\mathrm{CH}_{4(a q)}$ were far below equilibrium values, indicating that formation of these species was kinetically inhibited under the experimental conditions.

$\Sigma$ Formate concentrations show a very different trend during reaction of a $\mathrm{CO}_{2}$-rich fluid and serpentinized harzburgite at $200^{\circ} \mathrm{C}$. Measureable quantities of total formate were only detected $>48$ hours after the addition of $\mathrm{CO}_{2}$ at $200^{\circ} \mathrm{C}$. $\Sigma$ Formate concentrations then gradually increased with continued reaction and began to level off at $\sim 1.4 \mathrm{mmol} / \mathrm{kg}$. Comparison of measured and equilibrium $\Sigma$ formate concentrations indicates that dissolved $\mathrm{CO}_{2}$ and formate approached metastable equilibrium after $\sim 1130$ hours of reaction at $200^{\circ} \mathrm{C}$ (Figure $3.4 \mathrm{a}$ ). Rates of formate production in the present study are considerably slower than those reported in previous hydrothermal experiments at $200^{\circ} \mathrm{C}$, in which metastable equilibrium was attained within a few hundred hours of reaction at $\mathrm{pH} \leq 3$ (Seewald et al., 2006). This discrepancy may reflect differences in the in situ $\mathrm{pH}$, which has a significant impact on reaction rates. Carbonation experiments in the present study were conducted at higher in situ $\mathrm{pH}$ (4.8-5.5), which should result in slower reaction rates.

Methanol was present in low, but measureable, quantities (11-22 $\mu \mathrm{mol} / \mathrm{kg})$ during $\mathrm{CO}_{2}$ poor serpentinization at all temperatures, and was likely sourced from decomposition of background organic material. Methanol concentrations remained low following the injection of $\mathrm{CO}_{2}$ at $200^{\circ} \mathrm{C}$ and did not appreciably increase with continued reaction, reaching only 14 $\mu \mathrm{mol} / \mathrm{kg}$ after 2639 hours (Figure 3.4c). Thermodynamic calculations indicate that equilibration of dissolved $\mathrm{CO}_{2}$ with methanol should generate $7 \mathrm{mmol} / \mathrm{kg}$ methanol at the end of the $200^{\circ} \mathrm{C}$ carbonation experiment if $\mathrm{CH}_{4(a q)}$ formation were suppressed. Equilibrium methanol concentrations are $>\sim 3$ orders of magnitude higher than measured values, indicating strong kinetic barriers to methanol production at $200^{\circ} \mathrm{C}$.

Although fluids were not analyzed for methanol prior to the injection of $\mathrm{CO}_{2}$ at $300^{\circ} \mathrm{C}$ (experiment \#4), pre-injection concentrations can be estimated assuming methanol behaves as a conservative species. The calculated concentration of methanol immediately before the $\mathrm{CO}_{2}$ injection is $17 \mu \mathrm{mol} / \mathrm{kg}$, which is similar to the measured concentration at the end of the serpentinization-only experiment $\left(11 \mu \mathrm{mol} / \mathrm{kg}\right.$ in experiment \#3). Subsequent addition of a $\mathrm{CO}_{2}$ rich fluid at $300^{\circ} \mathrm{C}$ caused methanol concentrations to increase to well above their pre-injection 
values, reaching a maximum of $57 \mu \mathrm{mol} / \mathrm{kg}$ after 3222 hours of reaction (Figure 3.4d). The faster rate of methanol production after injection of $\mathrm{CO}_{2}$ at $300^{\circ} \mathrm{C}$ suggests that additional methanol was formed by reduction of the added $\mathrm{CO}_{2(a q)}$. However, comparison of measured and equilibrium concentrations indicates that methanol remained far below the concentration of 429 $\mu \mathrm{mol} / \mathrm{kg}$ predicted for metastable equilibrium at the end of the experiment.

Rates of methanol production observed during the present study differ from the results of Seewald et al. (2006) and Reeves (2010), who formed mmolar quantities of methanol on laboratory time scales at $200-325^{\circ} \mathrm{C}$. Seewald et al. (2006) generated $2 \mathrm{mmol} / \mathrm{kg}$ methanol after 332 hours of reaction at $200^{\circ} \mathrm{C}$, and $1 \mathrm{mmol} / \mathrm{kg}$ methanol after 216 hours of reaction at $300^{\circ} \mathrm{C}$. Reeves (2010) formed $0.5 \mathrm{mmol} / \mathrm{kg}$ methanol after 1900 hours of reaction at $325^{\circ} \mathrm{C}$. Both studies, however, used formic acid or $\mathrm{CO}_{(a q)}$ rather than $\mathrm{CO}_{2(a q)}$ as the initial carbon sources, which likely enhanced methanol formation rates by providing elevated concentrations of formic acid intermediates. In contrast, the present study used $\mathrm{CO}_{2(a q)}$ as the initial carbon source and only generated small quantities of intermediate carbon compounds - up to $1.3 \mathrm{mmol} / \mathrm{kg} \Sigma$ formate and no detectable CO. Furthermore, the presence of minerals in the present study, while providing potential catalytic surfaces for methanol formation, likely buffered the in situ $\mathrm{pH}$ to higher values than would occur solely in the aqueous phase. More alkaline $\mathrm{pH}$ favors the dissociation of formic acid ( $\mathrm{HCOOH})$ to formate (HCOO-). $\log \mathrm{K}_{\mathrm{a}}$ of formic acid dissociation is -4.4 and -5.2 at $200^{\circ} \mathrm{C}$ and $300^{\circ} \mathrm{C}$, respectively. The calculated in situ $\mathrm{pH}$ following injection of $\mathrm{CO}_{2}$ was $\geq 4.8$ at $200^{\circ} \mathrm{C}$ and $\geq 5.2$ at $300^{\circ} \mathrm{C}$, indicating that formate was the dominant $\Sigma$ formate species during the carbonation experiments (Figure 3.9). Since formic acid, rather than formate, participates in the reduction of $\mathrm{CO}_{2(a q)}$ to methanol (McCollom and Seewald, 2007), any suppression of formic acid concentrations would inhibit methanol formation.

\subsection{Implications for carbon reactions in ultramafic-influenced seafloor hydrothermal systems}

Results from laboratory experiments and field observations indicate that carbonate formation is kinetically faster than reduction of $\mathrm{CO}_{2(a q)}$ to $\mathrm{CH}_{4(a q)}$ and would be expected to effectively compete for dissolved inorganic carbon during active fluid convection in the subseafloor (Chapters 2-3; McCollom and Seewald, 2001; McCollom and Seewald, 2003; Foustoukos and Seyfried, 2004; Seewald et al., 2006; Fu et al., 2007; McDermott et al., 2015; 
McCollom, 2016). Precipitation of carbonate minerals would, therefore, have a strong impact on the potential for abiotic $\mathrm{CH}_{4}$ synthesis in ultramafic-influenced hydrothermal systems by removing dissolved inorganic carbon from circulating fluids. Indeed, fluids venting from the Lost City hydrothermal field are calcite saturated and contain low $\Sigma \mathrm{CO}_{2}$ concentrations and $\mathrm{CO}_{2} /{ }^{3} \mathrm{He}$ ratios, suggesting that subsurface carbonate precipitation has removed inorganic carbon from solution (Proskurowski et al., 2008).

A strong thermodynamic drive for $\mathrm{CH}_{4(a q)}$ formation, combined with sluggish reaction kinetics for $\mathrm{CO}_{2(a q)}$ reduction to $\mathrm{CH}_{4(a q)}$, allows for the accumulation of metastable carbon intermediaries in solution including formate and methanol. Previous studies have shown that dissolved $\mathrm{CO}_{2}$ and formate attain states of metastable equilibrium at $200-325^{\circ} \mathrm{C}$ on laboratory time scales that are comparable to estimated residence times of high-temperature fluids in midocean ridge hydrothermal systems (McCollom and Seewald, 2001; McCollom and Seewald, 2003; Seewald et al., 2006; Reeves, 2010). Although formate similarly achieved metastable equilibrium with $\mathrm{CO}_{2(a q)}$ on laboratory time scales in the present study, measured $\Sigma$ formate concentrations were low, particularly as $\Sigma \mathrm{CO}_{2}$ was consumed by carbonate formation. Figure 3.9 shows that higher in situ $\mathrm{pH}$ favors the production of more total formate. Accordingly, higher $\Sigma$ formate concentrations would be favored in ultramafic-influenced hydrothermal systems with neutral or alkaline $\mathrm{pH}$ fluids, such as the Lost City and Von Damm vent fields. Indeed, significant quantities of formate have been measured in hydrothermal fluids venting from Lost City (36-158 $\mu \mathrm{mol} / \mathrm{kg}$ ) and Von Damm (82-669 $\mu \mathrm{mol} / \mathrm{kg}$ ) (Lang et al., 2010; McDermott et al., 2015). However, higher $\mathrm{pH}$ also promotes the precipitation of carbonate minerals, thus limiting the total dissolved carbon available for formation of reduced carbon species, as is thought to occur in Lost City (Kelley et al., 2005). Lower temperatures similarly favor the formation of reduced carbon compounds (Seewald et al., 2006). However, while the thermodynamic drive for $\mathrm{CO}_{2}$ reduction increases at lower temperatures, reaction kinetics slow down appreciably.

Clearly, optimal conditions for abiotic organic synthesis require not only a thermodynamic driving force, but also sufficient reaction length. One way to achieve longer reaction times is to trap magmatic $\mathrm{CO}_{2}$ and $\mathrm{H}_{2}$ in mineral-hosted inclusions, which may be later extracted during hydrothermal alteration or fracturing of the host rock (Kelley, 1996; Kelley and Früh-Green, 1999; McCollom and Seewald, 2007; McDermott et al., 2015). Rocks exhumed along oceanic detachment faults take $0.3-0.7 \mathrm{Ma}$ to cool from $\sim 850^{\circ} \mathrm{C}$ to $200^{\circ} \mathrm{C}$ according to 
thermochronological measurements (John et al., 2004; Grimes et al., 2008; Baines et al., 2009; Schwartz et al., 2009; Grimes et al., 2011). Thus, carbon-rich fluid inclusions may persist in the subsurface for up to hundreds of thousands of years prior to their extraction by circulating hydrothermal fluids, potentially allowing ample time for carbon species to equilibrate. Indeed, $\mathrm{CH}_{4}$-rich fluid inclusions have been observed in mafic and ultramafic rocks from the Southwest Indian Ridge, Mid-Cayman Rise, and Zambales ophiolite (Chapter 4; Kelley, 1996; Kelley and Früh-Green, 1999; Kelley and Früh-Green, 2001).

Given sufficiently long reaction times, thermodynamics rather than kinetics is expected to control the partitioning of carbon among reduced and oxidizing species. Carbon speciation depends on a number of factors, including temperature, protolith composition, fluid chemistry, and W/R mass ratio. Hentscher (2012) conducted thermodynamic models to examine carbon reactions during seawater alteration of peridotite at moderate temperatures $\left(100-250^{\circ} \mathrm{C}\right)$. Model results demonstrate that $\mathrm{CH}_{4}$ is the dominant organic carbon species at elevated $\mathrm{H}_{2}$ activities predicted for subseafloor serpentinization systems (Hentscher, 2012). While $\mathrm{CH}_{4}$ appears to be stable at a wide range of $\mathrm{W} / \mathrm{R}$ mass ratios (1-400), carbonate minerals can stably co-exist with $\mathrm{CH}_{4}$ only at high W/R mass ratios (> 50) where $\mathrm{H}_{2(a q)}$ concentrations are low (Hentscher, 2012). Analysis of carbon-bearing fluid inclusions hosted in basement rocks from the Mid-Cayman Rise and the Zambales ophiolite (Chapter 4), reveals the presence of both $\mathrm{CH}_{4(g)}$ and carbonate minerals in the same inclusion. According to the models of Hentscher (2012), $\mathrm{CH}_{4}$ and carbonates should occur together only at high W/R mass ratios, which are clearly incompatible with the low $\mathrm{W} / \mathrm{R}$ mass ratios present in fluid inclusions. This indicates either metastable coexistence of these carbon species, or points to an initial fluid that is very different in composition from that of seawater. For instance, it is possible that $\mathrm{CH}_{4}$ and carbonate minerals may be stabilized at low $\mathrm{W} / \mathrm{R}$ mass ratios if $\mathrm{CO}_{2}$ concentrations in the interacting fluid are high due to an input of $\mathrm{CO}_{2}$ from magmatic degassing. Additional thermodynamic models are, therefore, needed to assess the role of fluid composition on carbon speciation during peridotite- $\mathrm{CO}_{2}$ interactions.

\section{CONCLUSIONS}

Laboratory experiments demonstrate that formation of carbonate minerals is the predominant sink for dissolved inorganic carbon during alteration of harzburgite by $\mathrm{CO}_{2}$-rich 
fluids at redox and temperature conditions typical for ultramafic-influenced seafloor hydrothermal systems. Although measureable quantities of reduced carbon species were generated by reduction of $\mathrm{CO}_{2(\mathrm{aq})}$, their concentrations were low and account for only a minor carbon sink during mineral carbonation. Formate achieved metastable equilibrium with dissolved $\mathrm{CO}_{2}$ on laboratory time scales at $200-300^{\circ} \mathrm{C}$. In contrast, methanol attained concentrations well below those predicted by thermodynamic equilibrium, particularly at low temperatures $\left(200^{\circ} \mathrm{C}\right)$, indicating strong kinetic barriers to methanol formation at the experimental conditions. Despite the strong thermodynamic drive for $\mathrm{CH}_{4}$ formation, no appreciable $\mathrm{CH}_{4}$ was produced via aqueous reduction of $\mathrm{CO}_{2}$ in experiments from this study and Chapter 2. These results are consistent with previous laboratory studies which indicate that reduction of $\mathrm{CO}_{2(a q)}$ to $\mathrm{CH}_{4(a q)}$ is prohibitively slow on time scales of active fluid circulation in mid-ocean ridge hydrothermal systems.

\section{ACKNOWLEDGEMENTS}

I would like to thank Carl Johnson at WHOI for performing the elemental carbon analyses, and Davide Ciceri at MIT for performing the BET measurement. Thank you to Jim Eckert at Yale University for assistance with electron microprobe analyses. 


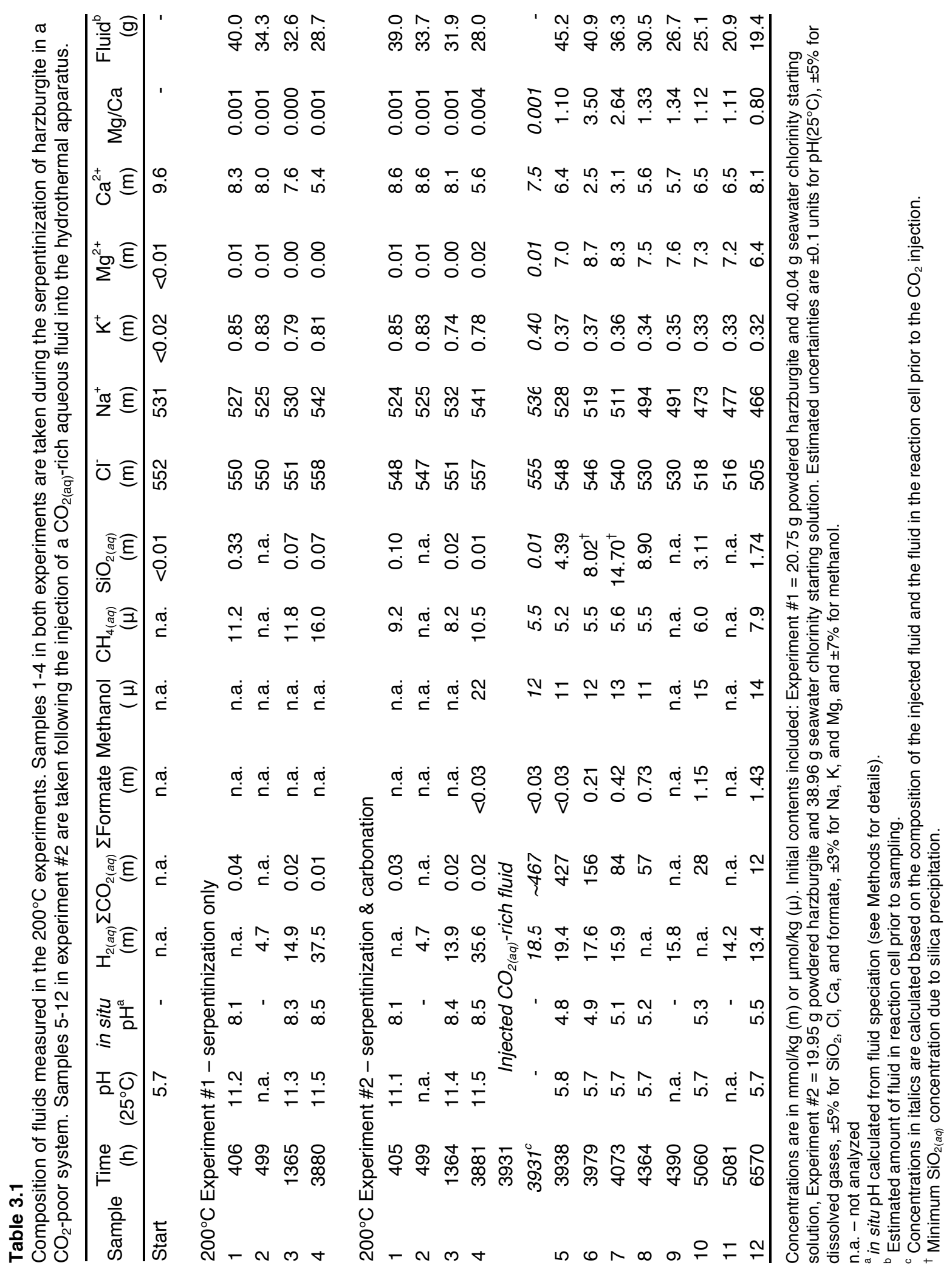




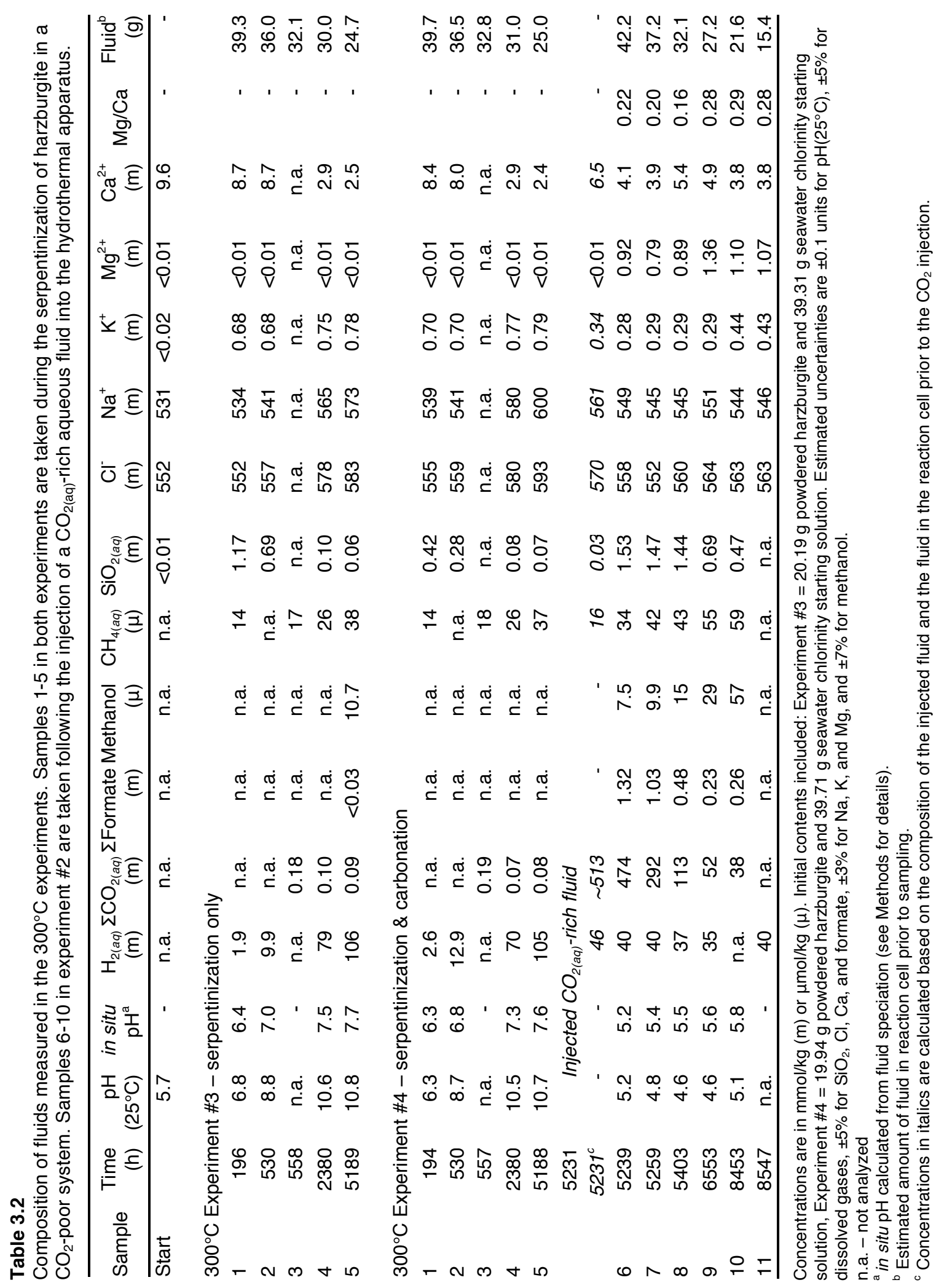


Table 3.3

Electron microprobe analyses of secondary minerals (wt.\%) in the $200^{\circ} \mathrm{C}$ experiments.

\begin{tabular}{|c|c|c|c|c|c|c|c|c|c|c|}
\hline \multirow[b]{3}{*}{ \# analyses } & \multicolumn{6}{|c|}{ Direct replacement minerals } & \multicolumn{4}{|c|}{ Interstitial, zoned carbonates } \\
\hline & $\begin{array}{r}\text { Srp } \\
\text { after Oliv }\end{array}$ & $1 \sigma$ & $\begin{array}{l}\text { Ca-Mgs } \\
\text { after Oliv }\end{array}$ & $1 \sigma$ & $\begin{array}{r}\text { Ca-Mgs } \\
\text { after Opx }\end{array}$ & $1 \sigma$ & $\begin{array}{r}\text { Core- } \\
\text { Ca-Mgs }\end{array}$ & $1 \sigma$ & $\begin{array}{r}\text { Rim- } \\
\text { Ca-Mgs }\end{array}$ & $1 \sigma$ \\
\hline & 3 & & 2 & & 2 & & 4 & & 6 & \\
\hline $\mathrm{SiO}_{2}$ & 39.80 & 0.43 & 0.21 & 0.11 & 0.55 & 0.45 & 0.37 & 0.54 & 0.19 & 0.22 \\
\hline $\mathrm{TiO}_{2}$ & 0.10 & 0.00 & & & & & & & & \\
\hline $\mathrm{Al}_{2} \mathrm{O}_{3}$ & 1.03 & 0.05 & & & & & & & & \\
\hline $\mathrm{Cr}_{2} \mathrm{O}_{3}$ & 0.00 & 0.00 & & & & & & & & \\
\hline $\mathrm{FeO}^{*}$ & 5.70 & 0.16 & 10.50 & 0.50 & 9.4 & 1.6 & 8.10 & 0.67 & 10.67 & 0.47 \\
\hline $\mathrm{MnO}$ & 0.10 & 0.00 & 0.61 & 0.31 & 0.54 & 0.04 & 0.53 & 0.13 & 0.57 & 0.25 \\
\hline $\mathrm{MgO}$ & 37.57 & 0.42 & 28.80 & 2.70 & 32.15 & 3.05 & 30.33 & 1.64 & 29.20 & 1.35 \\
\hline $\mathrm{NiO}$ & 0.34 & 0.24 & & & & & & & & \\
\hline $\mathrm{CoO}$ & n.d. & n.d. & & & & & & & & \\
\hline $\mathrm{CaO}$ & 0.22 & 0.06 & 10.29 & 1.91 & 7.89 & 2.41 & 11.13 & 2.16 & 9.98 & 1.35 \\
\hline $\mathrm{Na}_{2} \mathrm{O}$ & 0.13 & 0.07 & & & & & & & & \\
\hline $\mathrm{K}_{2} \mathrm{O}$ & 0.01 & 0.00 & & & & & & & & \\
\hline $\mathrm{SO}_{3}$ & n.d. & n.d. & & & & & & & & \\
\hline $\mathrm{Cl}$ & 0.32 & 0.08 & & & & & & & & \\
\hline $\mathrm{H}_{2} \mathrm{O}^{\mathrm{a}}$ & 14.93 & 0.67 & & & & & & & & \\
\hline $\mathrm{CO}_{2}{ }^{\mathrm{a}}$ & & & 49.47 & 0.24 & 49.59 & 1.23 & 49.54 & 0.70 & 49.40 & 0.51 \\
\hline Total & 85.07 & 0.67 & 50.53 & 0.24 & 50.41 & 1.23 & 50.46 & 0.70 & 50.60 & 0.51 \\
\hline$M g \#^{b}$ & 92.15 & 0.24 & 82.9 & 2.0 & 85.7 & 3.2 & 87.0 & 0.8 & 83.0 & 0.8 \\
\hline $\mathrm{mol} \% \mathrm{MgCO}_{3}{ }^{\mathrm{C}}$ & & & 67.8 & 5.0 & 74.0 & 6.3 & 70.2 & 3.4 & 68.4 & 2.5 \\
\hline $\mathrm{mol} \% \mathrm{FeCO}_{3}{ }^{\mathrm{c}}$ & & & 13.9 & 0.9 & 12.2 & 2.2 & 10.5 & 0.8 & 14.0 & 0.6 \\
\hline $\mathrm{mol} \% \mathrm{CaCO}_{3}{ }^{\mathrm{C}}$ & & & 17.5 & 3.6 & 13.1 & 4.1 & 18.6 & 3.7 & 16.8 & 2.4 \\
\hline
\end{tabular}

n.d. - not detected

* Total Fe as $\mathrm{FeO}$

${ }^{\mathrm{a}} \mathrm{H}_{2} \mathrm{O}$ and $\mathrm{CO}_{2}$ calculated by difference from $100 \%$

${ }^{\mathrm{b}} \mathrm{Mg} \#=$ molar $\mathrm{Mg} /(\mathrm{Mg}+\mathrm{Fe}) \times 100$

${ }^{c} \mathrm{~mol}^{\circ} \% \mathrm{YCO}_{3}=$ molar $\mathrm{Y} /(\mathrm{Mg}+\mathrm{Fe}+\mathrm{Ca}+\mathrm{Mn}) \times 100$ 


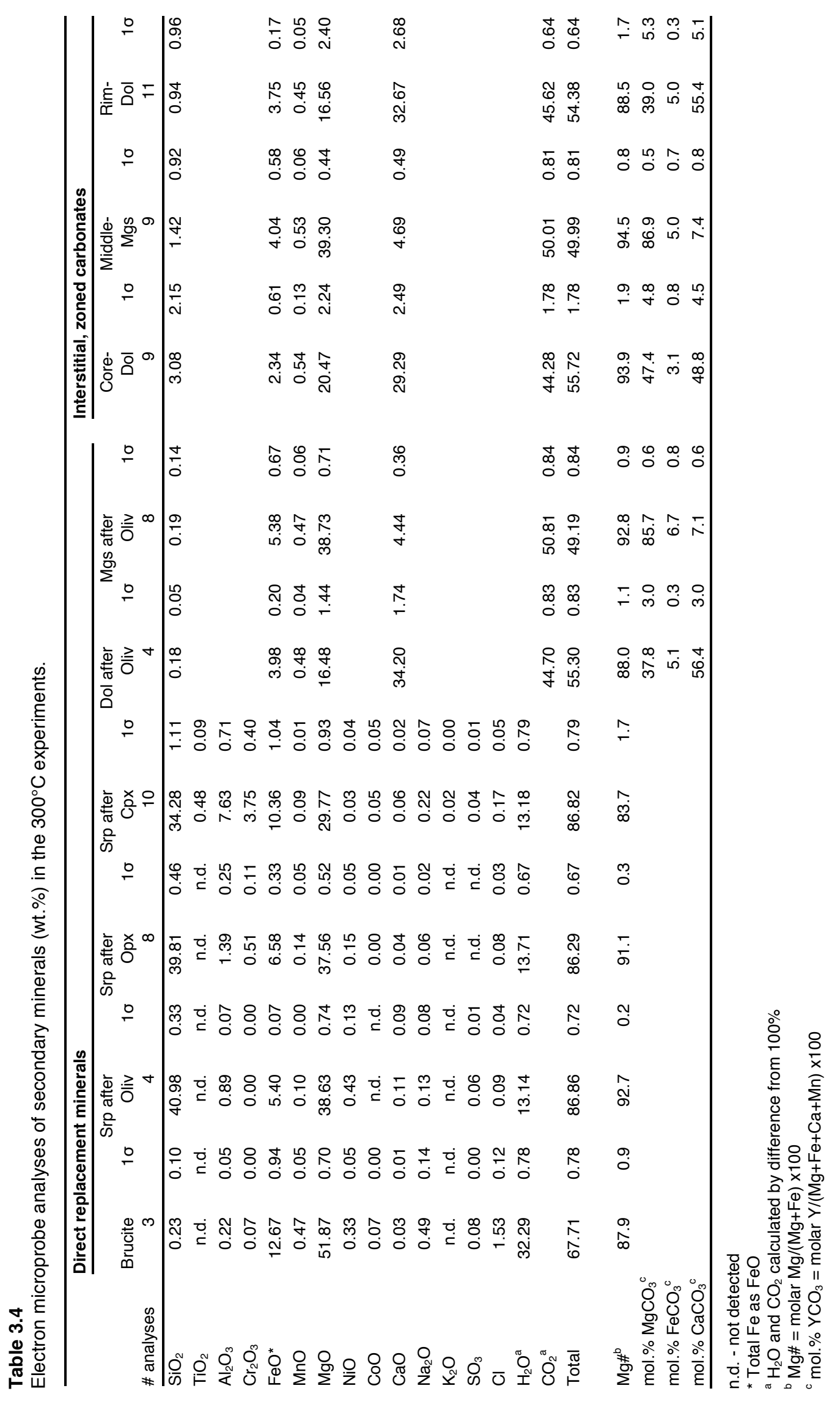


Table 3.5

Bulk element compositions of the harzburgite starting material and experimental alteration products determined by XRF, Fe titration, and bulk carbon analysis. All oxides are reported in wt.\%.

\begin{tabular}{|c|c|c|c|c|c|}
\hline \multirow{2}{*}{\multicolumn{2}{|c|}{ Harzburgite ${ }^{a}$}} & \multicolumn{2}{|l|}{$200^{\circ} \mathrm{C}$} & \multicolumn{2}{|l|}{$300^{\circ} \mathrm{C}$} \\
\hline & & $\begin{array}{r}\text { Experiment \#1 } \\
\text { serpentinization } \\
\text { only }\end{array}$ & $\begin{array}{r}\text { Experiment \#2 } \\
\text { serpentinization } \\
+ \text { carbonation }\end{array}$ & $\begin{array}{r}\text { Experiment \#3 } \\
\text { serpentinization } \\
\text { only }\end{array}$ & $\begin{array}{r}\text { Experiment \#4 } \\
\text { serpentinization } \\
+ \text { carbonation }\end{array}$ \\
\hline$\overline{\mathrm{SiO}_{2}}$ & 44.66 & 40.97 & 40.33 & 37.94 & 38.21 \\
\hline $\mathrm{TiO}_{2}$ & 0.01 & 0.02 & 0.02 & 0.02 & 0.02 \\
\hline $\mathrm{Al}_{2} \mathrm{O}_{3}$ & 1.01 & 1.19 & 1.10 & 1.01 & 1.08 \\
\hline $\mathrm{Cr}_{2} \mathrm{O}_{3}$ & 0.31 & 0.40 & 0.39 & 0.38 & 0.38 \\
\hline $\mathrm{FeO}_{\text {Tot }}^{\mathrm{b}}$ & 7.67 & 7.05 & 6.95 & 6.52 & 6.50 \\
\hline $\mathrm{FeO}^{\mathrm{c}}$ & - & 5.2 & 5.3 & 2.9 & 3.6 \\
\hline $\mathrm{Fe}_{2} \mathrm{O}_{3}{ }^{d}$ & - & 2.1 & 1.8 & 4.0 & 3.2 \\
\hline $\mathrm{MnO}$ & 0.124 & 0.113 & 0.111 & 0.105 & 0.102 \\
\hline $\mathrm{MgO}$ & 45.96 & 42.00 & 41.36 & 39.00 & 38.91 \\
\hline $\mathrm{NiO}$ & 0.306 & 0.289 & 0.286 & 0.263 & 0.267 \\
\hline $\mathrm{Co}_{3} \mathrm{O}_{4}$ & - & 0.015 & 0.015 & 0.013 & 0.013 \\
\hline $\mathrm{CuO}$ & 0.001 & 0.007 & bdl & bdl & bdl \\
\hline $\mathrm{CaO}$ & 0.65 & 0.84 & 0.88 & 0.81 & 0.81 \\
\hline $\mathrm{Na}_{2} \mathrm{O}$ & 0.04 & 0.12 & 0.15 & 0.04 & 0.13 \\
\hline $\mathrm{K}_{2} \mathrm{O}$ & bdl & 0.02 & 0.02 & bdl & 0.04 \\
\hline $\mathrm{P}_{2} \mathrm{O}_{5}$ & 0.02 & 0.02 & 0.02 & 0.02 & 0.02 \\
\hline $\mathrm{V}_{2} \mathrm{O}_{5}$ & 0.004 & 0.005 & 0.006 & 0.007 & 0.005 \\
\hline $\mathrm{LOI}^{\mathrm{e}}$ & - & 6.60 & 8.38 & 11.99 & 13.59 \\
\hline Total & 100.77 & 99.86 & 100.20 & 98.53 & 100.40 \\
\hline $\mathrm{Fe}^{+3} / \Sigma \mathrm{Fe}$ & - & 0.26 & 0.24 & 0.56 & 0.45 \\
\hline$\%$ TC & 0.01 & 0.05 & 0.34 & 0.04 & 1.07 \\
\hline$\% \mathrm{OC}$ & 0.01 & 0.02 & 0.02 & 0.01 & 0.06 \\
\hline$\%$ IC & bdl & 0.03 & 0.32 & 0.03 & 1.00 \\
\hline
\end{tabular}

Detection limits are: 0.1 wt.\% for $\mathrm{FeO} ; 0.01$ wt.\% for $\mathrm{SiO}_{2}, \mathrm{TiO}_{2}, \mathrm{Al}_{2} \mathrm{O}_{3}, \mathrm{Cr}_{2} \mathrm{O}_{3}, \mathrm{FeO}_{\text {Tot }}, \mathrm{MgO}, \mathrm{CaO}, \mathrm{Na}_{2} \mathrm{O}, \mathrm{K}_{2} \mathrm{O}$, $\mathrm{P}_{2} \mathrm{O}_{5}$, and $\mathrm{LOI} ; 0.005$ wt.\% for $\mathrm{Co}_{3} \mathrm{O}_{4}$ and $\mathrm{CuO} ; 0.003$ wt. \% for $\mathrm{NiO}$ and $\mathrm{V}_{2} \mathrm{O}_{5} ; 0.001$ wt. $\%$ for $\mathrm{MnO}$.

bdl - below detection limit

${ }^{a}$ XRF data of harzburgite starting material from Klein et al. (2015).

${ }^{\mathrm{b}}$ Total $\mathrm{Fe}$ as $\mathrm{FeO}$.

${ }^{\mathrm{c}} \mathrm{FeO}$ determined by titration.

${ }^{\mathrm{d}} \mathrm{Fe}_{2} \mathrm{O}_{3}$ calculated from $\mathrm{FeO}$ and total $\mathrm{Fe}$.

${ }^{\mathrm{e}}$ Loss on ignition, adjusted for the difference in oxygen between $\mathrm{FeO}$ and $\mathrm{Fe}_{2} \mathrm{O}_{3}$. 


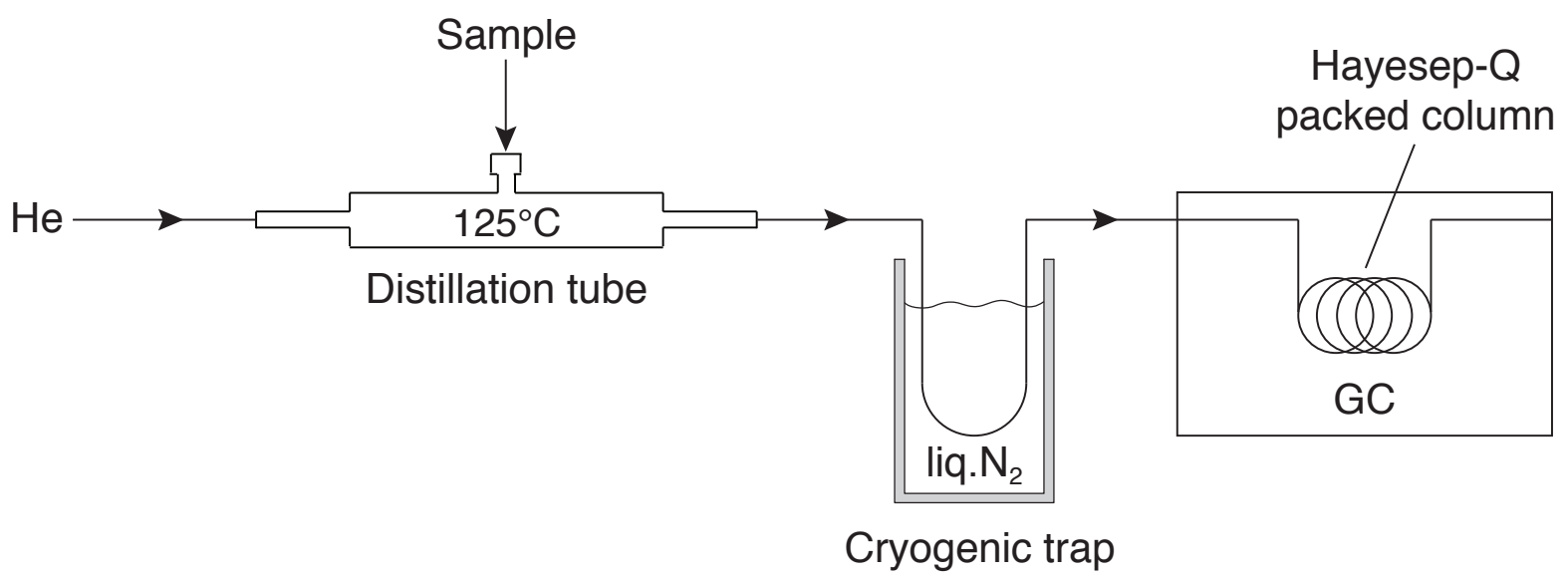

Figure 3.1

Schematic diagram of the gas chromatography (GC) system for measuring methanol in seawater solutions. 
$200^{\circ} \mathrm{C}$
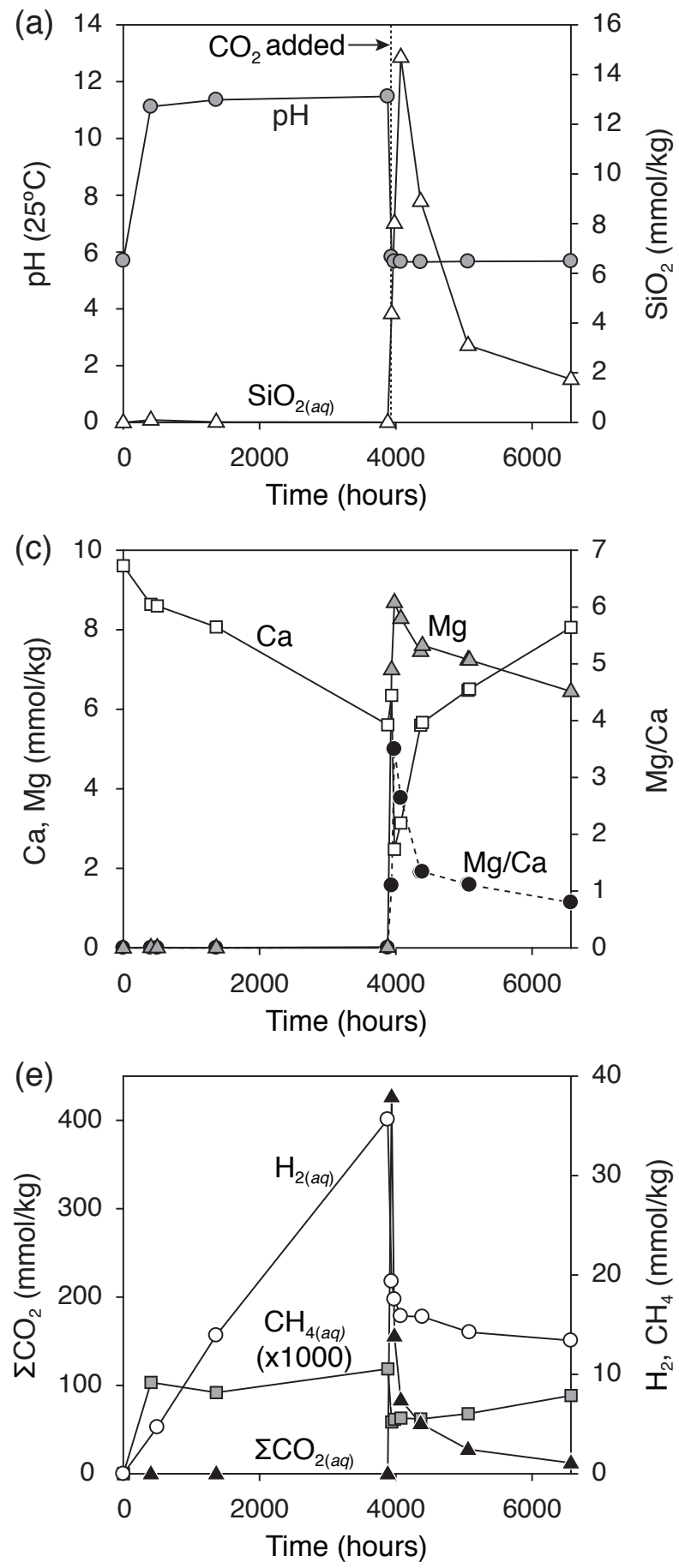

$300^{\circ} \mathrm{C}$
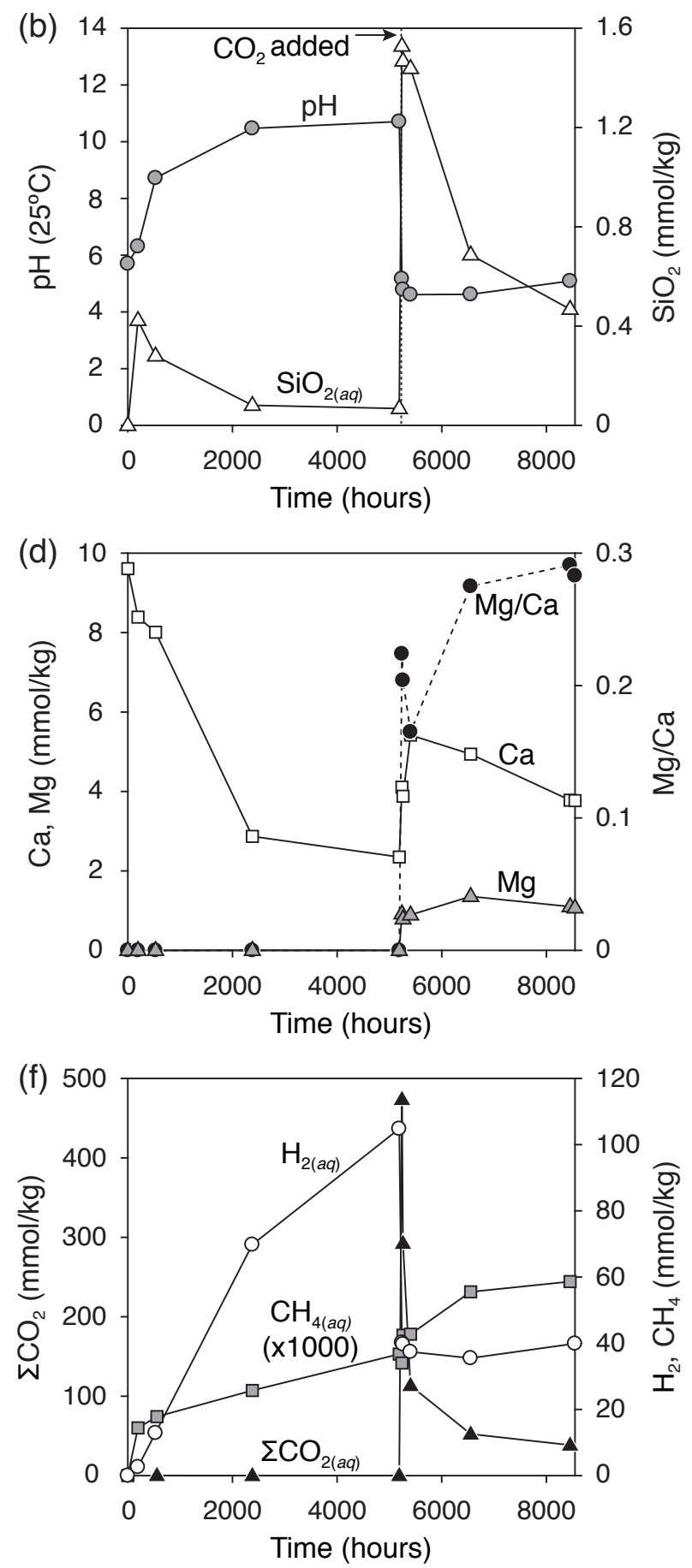

Figure 3.2

Variations in fluid chemistry as a function of reaction time during serpentinization and subsequent carbonation of harzburgite at $200^{\circ} \mathrm{C}$ and $300^{\circ} \mathrm{C}, 35 \mathrm{MPa}$ (experiments 2 and 4). (a-b) $\mathrm{pH}\left(25^{\circ} \mathrm{C}\right)$ and $\mathrm{SiO}_{2(a q)}$, (c-d) dissolved $\mathrm{Ca}, \mathrm{Mg}$, and $\mathrm{Mg} / \mathrm{Ca}$ ratio, and (e-f) dissolved $\mathrm{H}_{2}, \mathrm{CH}_{4}$, and $\Sigma \mathrm{CO}_{2}$. 


\section{Figure 3.3}

Backscattered electron (BSE) images of primary and secondary minerals following $\mathrm{CO}_{2}$-poor serpentinization of harzburgite at $200^{\circ} \mathrm{C}$ and $300^{\circ} \mathrm{C}$. All primary mineral surfaces are rimmed by thin chrysotile fibers that grew into the interstitial spaces and cemented together the initial harzburgite powder.

$\mathbf{2 0 0}^{\circ} \mathrm{C}$ (a-e): (a-b) Relict olivine altered to serpentine + brucite. Olivine shows abundant etch pits resulting from dissolution, and is directly rimmed by serpentine minerals with a spherical morphology (polyhedral serpentine?). Brucite occurs as thin plates that radiate outward from the relict olivine surface or extend from one part of the serpentine rim to another. (c) Relict orthopyroxene rimmed by serpentine having a spherical morphology (polyhedral serpentine?). (d) Unaltered clinopyroxene coated with chrysotile fibers. (e) Trace euhedral calcite precipitated from solution.

$3^{300} \mathbf{C}$ (f-j): (f-g) Relict olivine altered to serpentine + brucite + magnetite. Brucite occurs as elongated pseudohexagonal plates that radiate outward from the relict olivine surface or span the entire length of the cavity surrounding olivine. Magnetite occurs as euhedral to subhedral crystals situated between brucite and the surrounding serpentine, or intergrown with brucite. Brucite and magnetite are rimmed by fine-grained, platy and fibrous serpentine minerals. Secondary heazlewoodite in (g) is overgrown by magnetite. (h) Primary silicate, most likely orthopyroxene, completely altered to serpentine + magnetite. (i) Clinopyroxene exhibiting minor alteration to serpentine. (j) Trace euhedral calcite precipitated from solution.

Abbreviations: Brc - brucite, Cal - calcite, Cpx - clinopyroxene, Ctl - chrysotile, Hzl heazlewoodite, Mag - magnetite, Ol - olivine, Opx - orthopyroxene, Srp - serpentine 

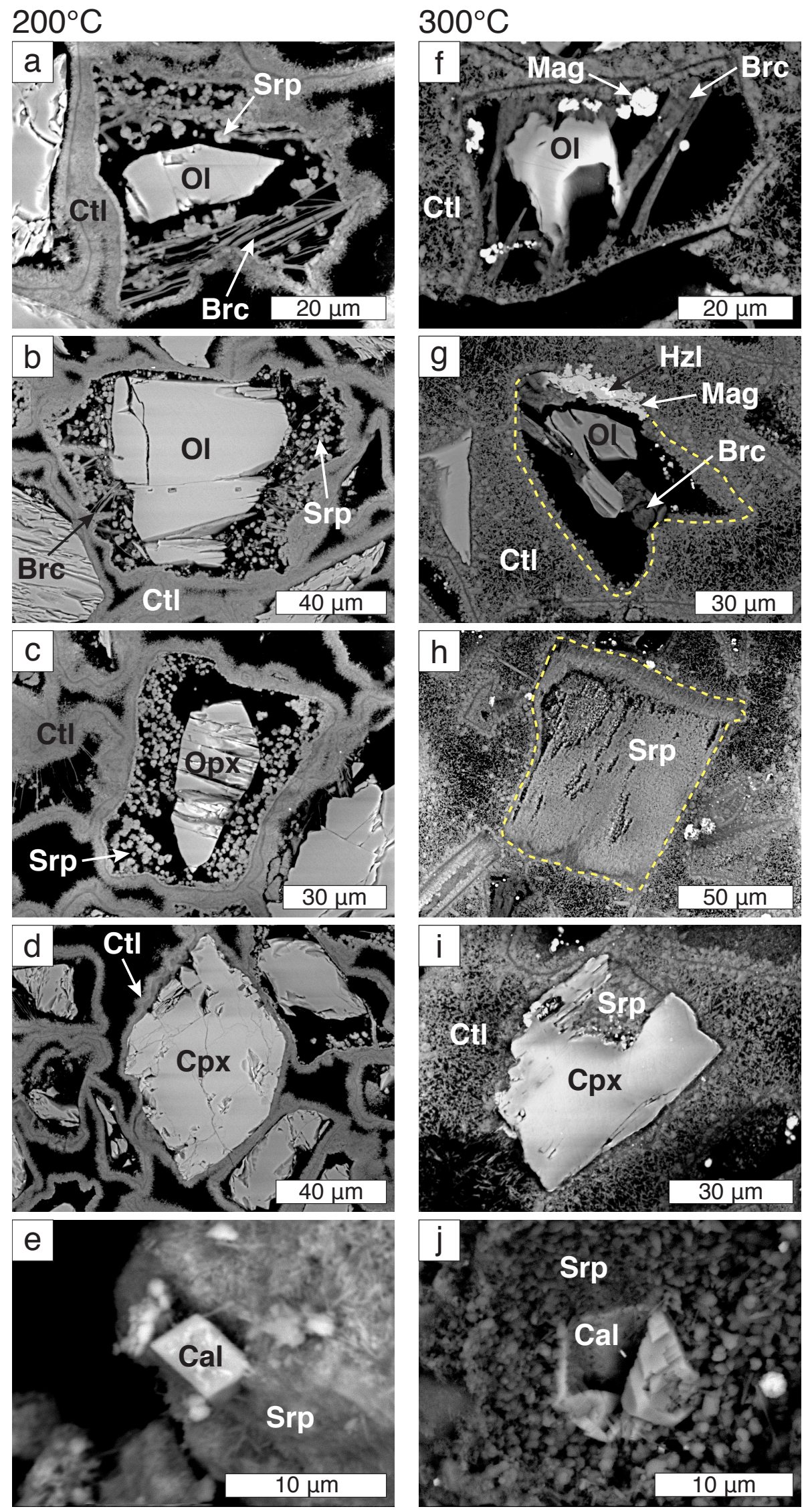
$200^{\circ} \mathrm{C}$
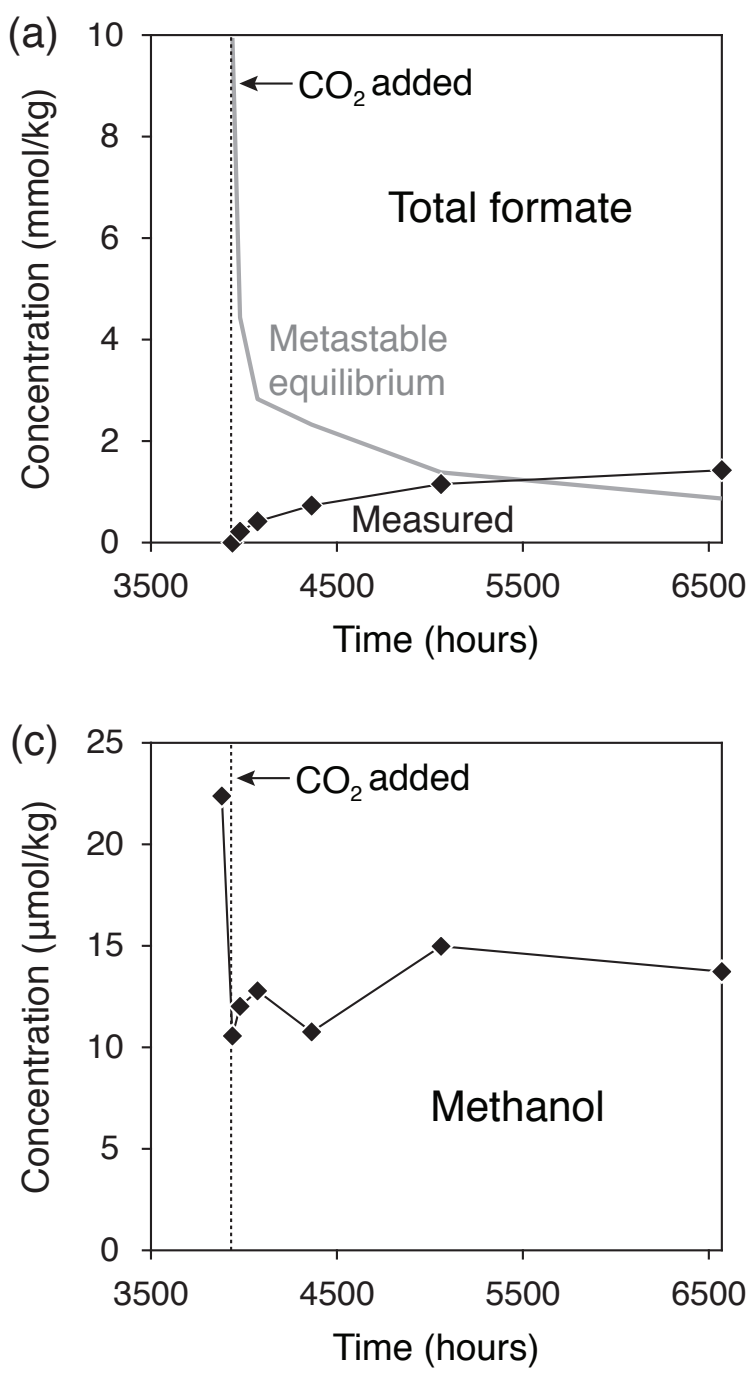

$300^{\circ} \mathrm{C}$
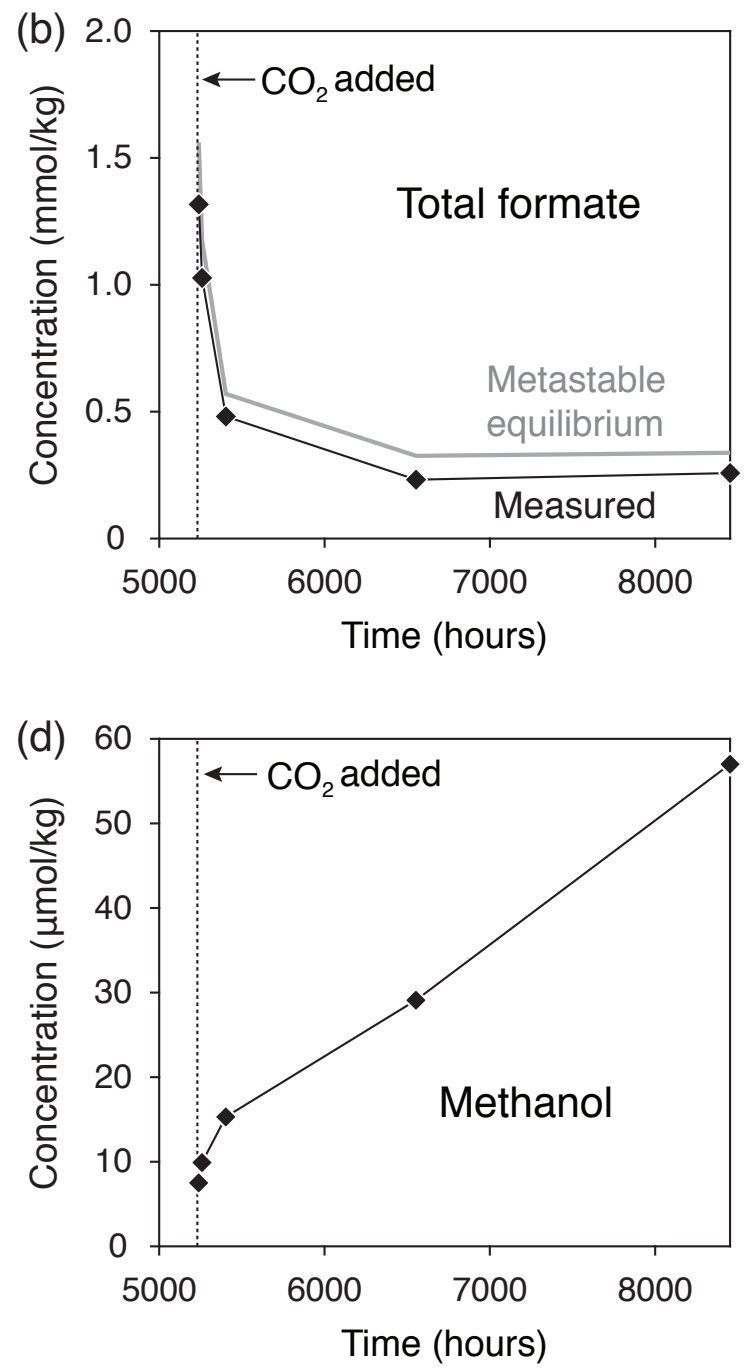

Figure 3.4

Measured concentrations of (a-b) $\Sigma$ formate and (c-d) methanol following the addition of a $\mathrm{CO}_{2(a q)}$-rich aqueous fluid into actively serpentinizing harzburgite at $200^{\circ} \mathrm{C}$ and $300^{\circ} \mathrm{C}, 35 \mathrm{MPa}$. Metastable equilibrium concentrations of $\Sigma$ formate were calculated by speciating measured fluid compositions at in situ conditions while suppressing the formation of methanol and $\mathrm{CH}_{4(a q)}$. Complete equilibrium was allowed between $\mathrm{H}_{2(a q)}, \mathrm{CO}_{2(a q)}, \mathrm{CO}_{(a q)}$, formate, and formaldehyde. 


\section{Figure 3.5}

Backscattered electron (BSE) images of the alteration solids following carbonation of serpentinized harzburgite at $200^{\circ} \mathrm{C}$ and $300^{\circ} \mathrm{C}$.

$200^{\circ} \mathbf{C}$ (a-e): (a) Euhedral magnesite found suspended in the fluid upon termination of the experiment. (b) Magnesite precipitated in interstitial pore spaces, showing compositional zonation in Fe content. (c) Relict olivine directly rimmed by a discontinuous layer of magnesite, and overgrown by fibrous chrysotile. (d) Relict orthopyroxene partially replaced by magnesite + serpentine. (e) Clinopyroxene showing minor alteration to serpentine. Clinopyroxene exhibits abundant dissolution features, including linear and conical etch pits.

$300^{\circ} \mathbf{C}$ (f-j): (f) Euhedral dolomite found suspended in solution upon termination of the experiment. (g) Compositionally zoned carbonate precipitated in the interstitial pore space. Carbonate interiors are typically composed of dolomite overgrown by magnesite. Carbonate exteriors comprise Ca-rich dolomite that exhibits gradual depletion in Ca towards the rim. (h-i) Relict olivine directly rimmed by a semi-continuous layer of carbonate minerals, followed by a continuous layer of lizardite \pm magnetite. Olivine is more commonly replaced by Ca-rich dolomite, and less commonly by magnesite. In some instances, both dolomite and magnesite are observed to rim the same olivine grain (i). (j) Clinopyroxene extensively altered to Fe-rich serpentine \pm magnetite.

Abbreviations: Cpx - clinopyroxene, Dol - dolomite, Mag - magnetite, Mgs - magnesite, Ol olivine, Opx - orthopyroxene, Srp - serpentine 
$200^{\circ} \mathrm{C}$

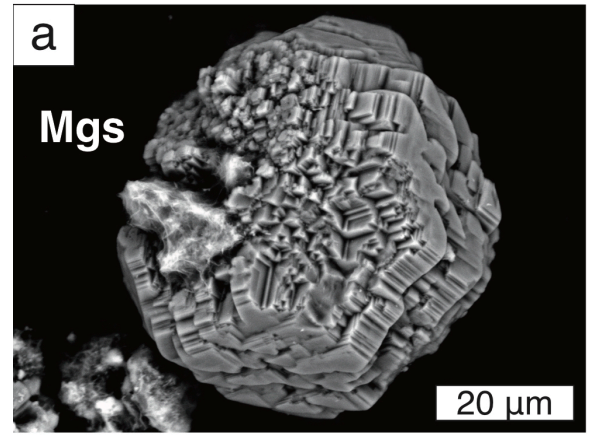

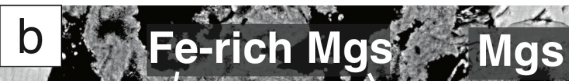

Mgs 1 - en
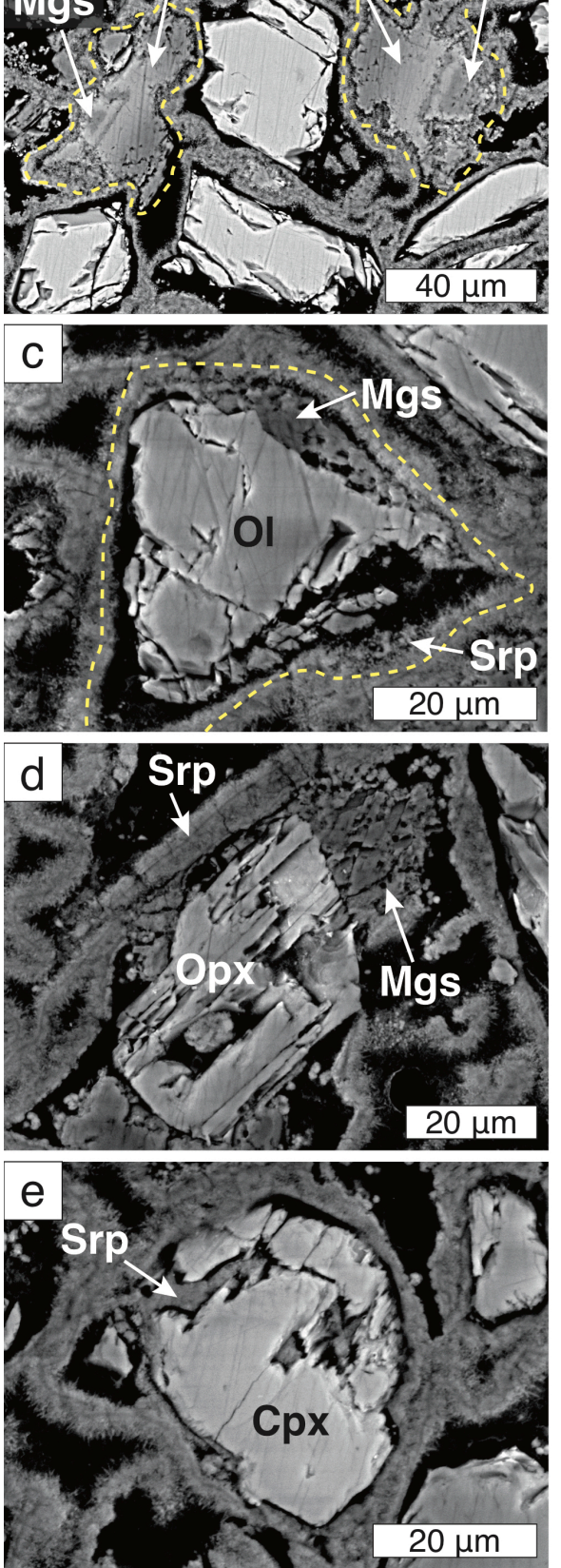

$300^{\circ} \mathrm{C}$
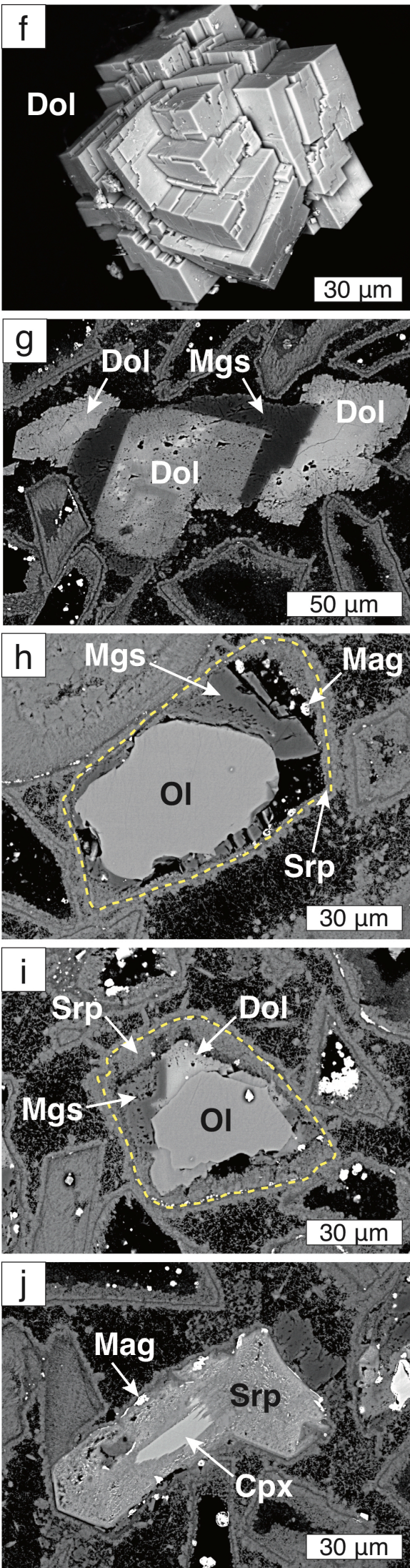


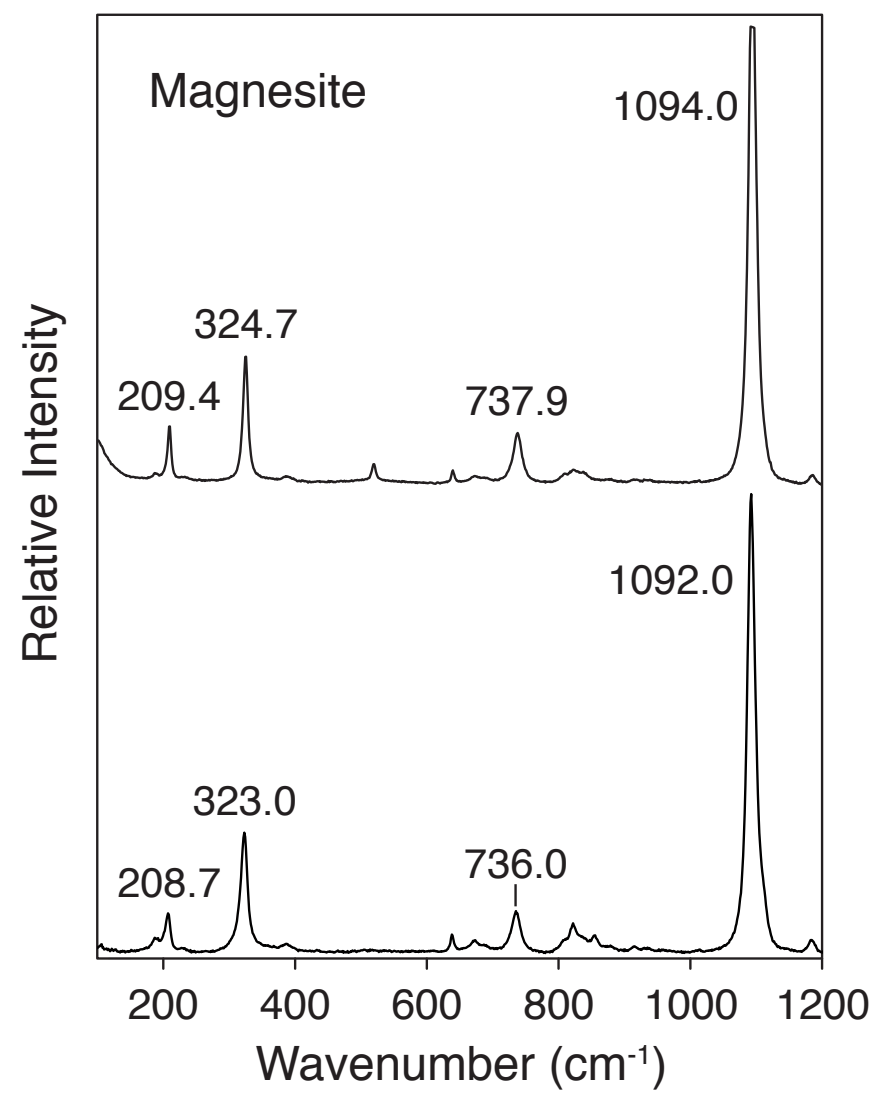

Figure 3.6

Raman spectra of magnesite formed during carbonation of harzburgite at $200^{\circ} \mathrm{C}$, showing the range in frequencies observed for the characteristic carbonate Raman bands. 


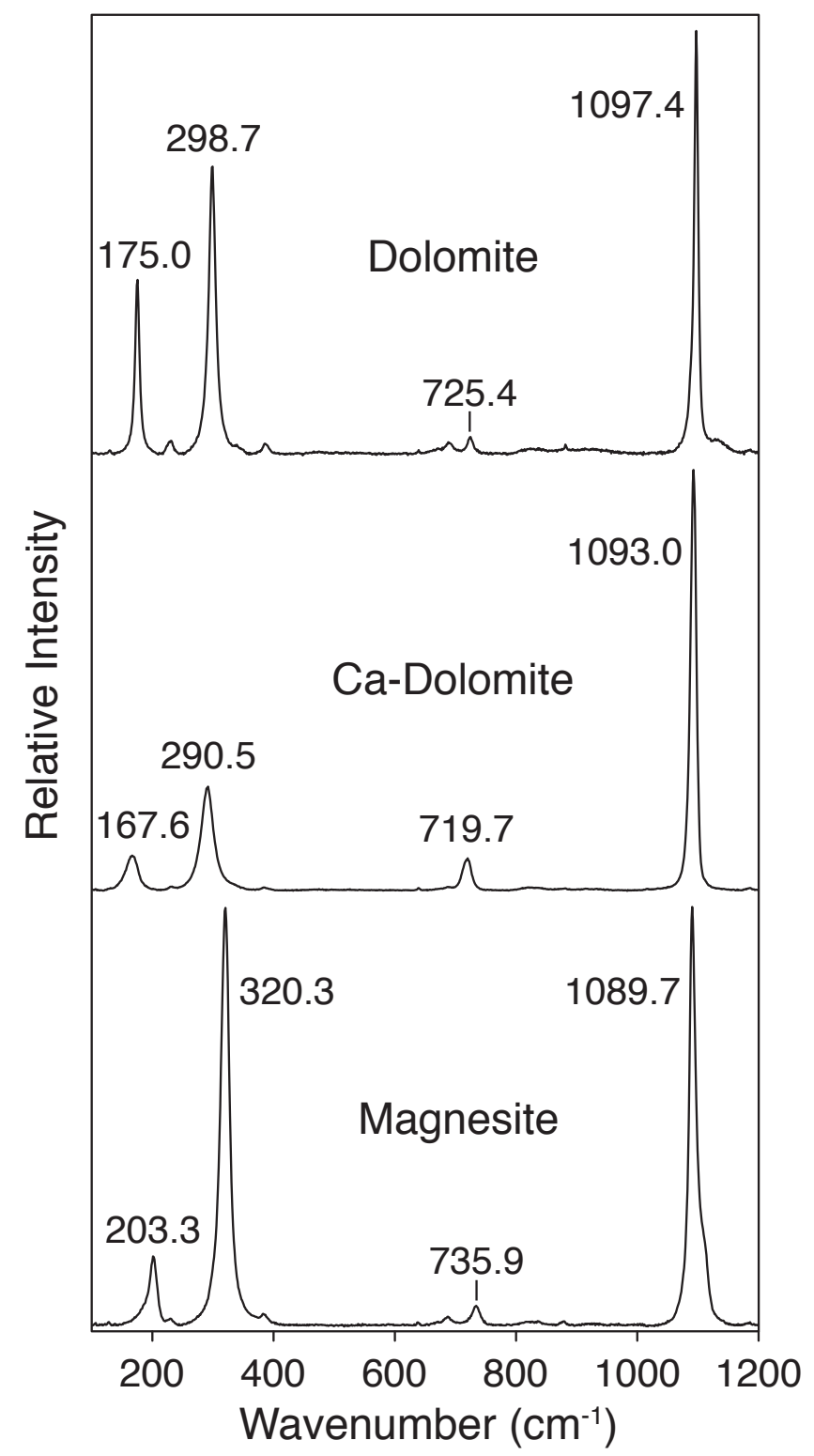

Figure 3.7

Representative Raman spectra of carbonate minerals formed during carbonation of harzburgite at $300^{\circ} \mathrm{C}$. 
$200^{\circ} \mathrm{C}$
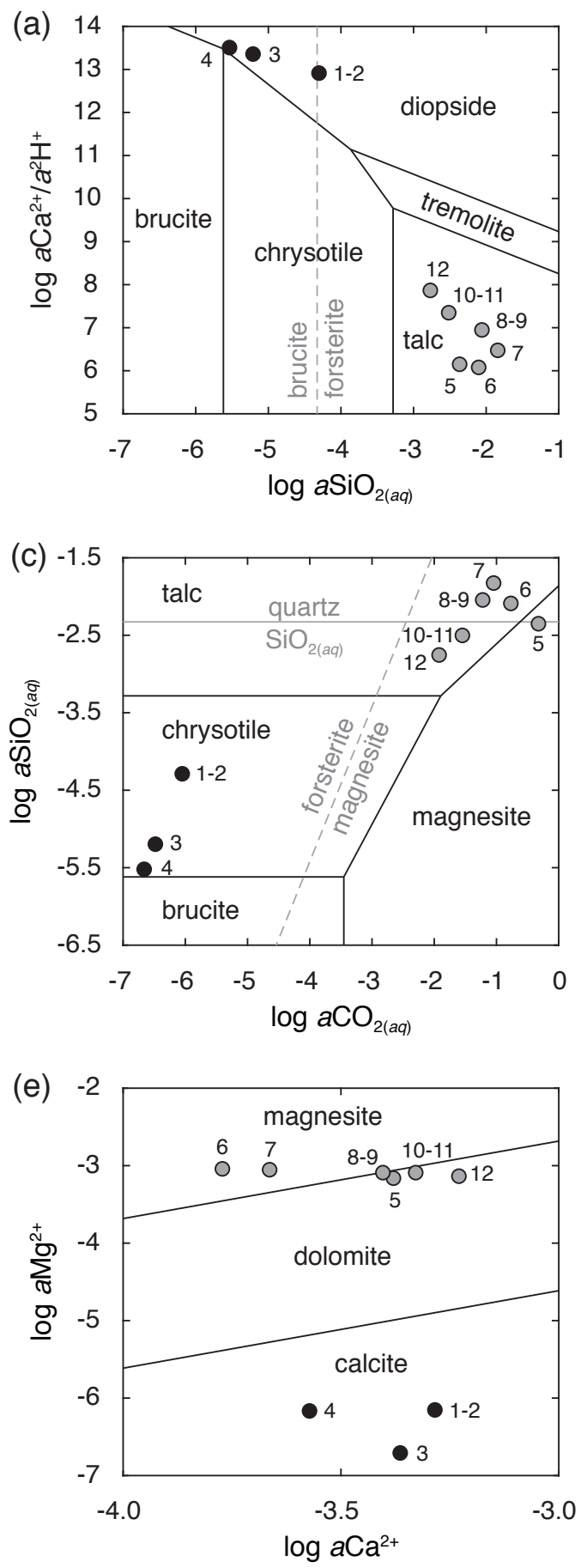

$300^{\circ} \mathrm{C}$
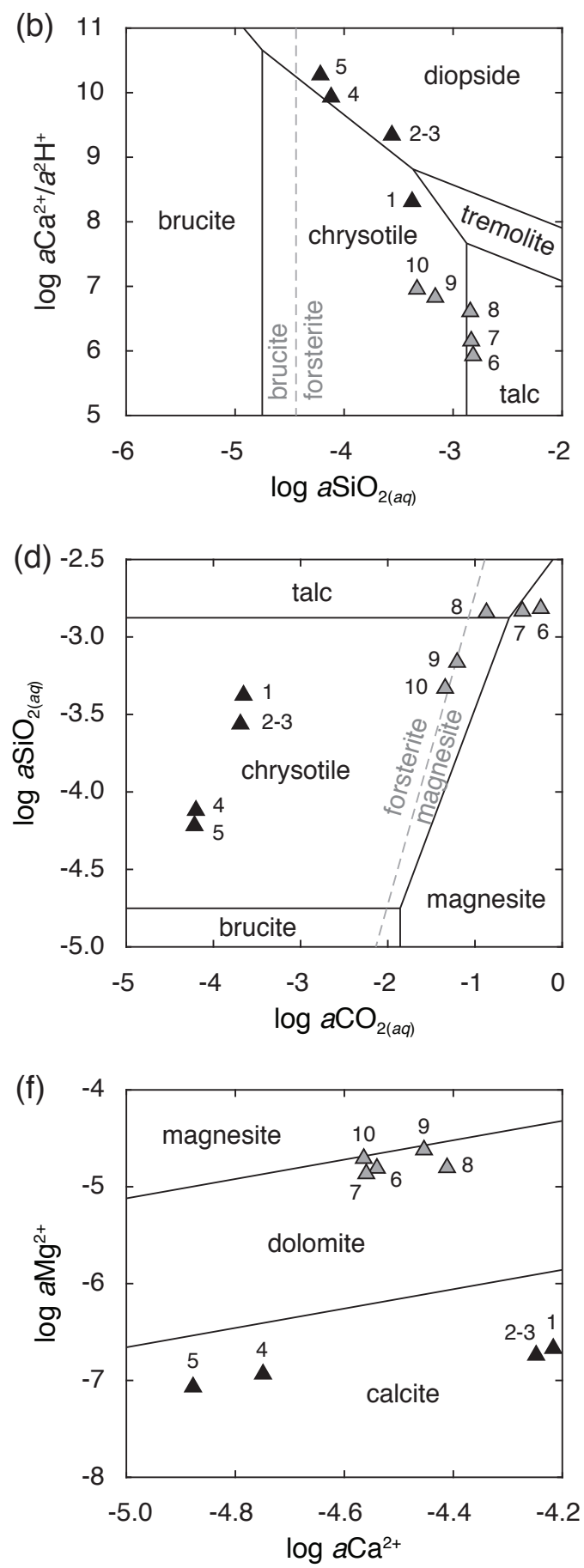

\section{Figure 3.8}

Activity-activity diagrams depicting phase equilibria in the $\mathrm{MgO}-\mathrm{CaO}-\mathrm{SiO}_{2}-\mathrm{H}_{2} \mathrm{O}-\mathrm{CO}_{2}$ system at $200^{\circ} \mathrm{C}$ and $300^{\circ} \mathrm{C}, 35 \mathrm{MPa}$. Numbered symbols represent speciated fluid compositions sampled during $\mathrm{CO}_{2}$-poor serpentinization (black symbols) and subsequent carbonation (gray symbols) of harzburgite (experiments 2 and 4). Dashed lines denote metastable reactions. (a-b) Plot of $\log \mathrm{aCa}^{2+} / \mathrm{a}^{2} \mathrm{H}^{+}$vs. $\log \mathrm{aSiO}_{2(\mathrm{aq})}$ (c-d) Plot of $\log \mathrm{aSiO}_{2(\mathrm{aq})}$ vs. $\log \mathrm{aCO}_{2(\mathrm{aq})}$ (e-f) Plot of $\log$ $\mathrm{aMg}^{2+}$ vs. $\log \mathrm{aCa}^{2+}$. 

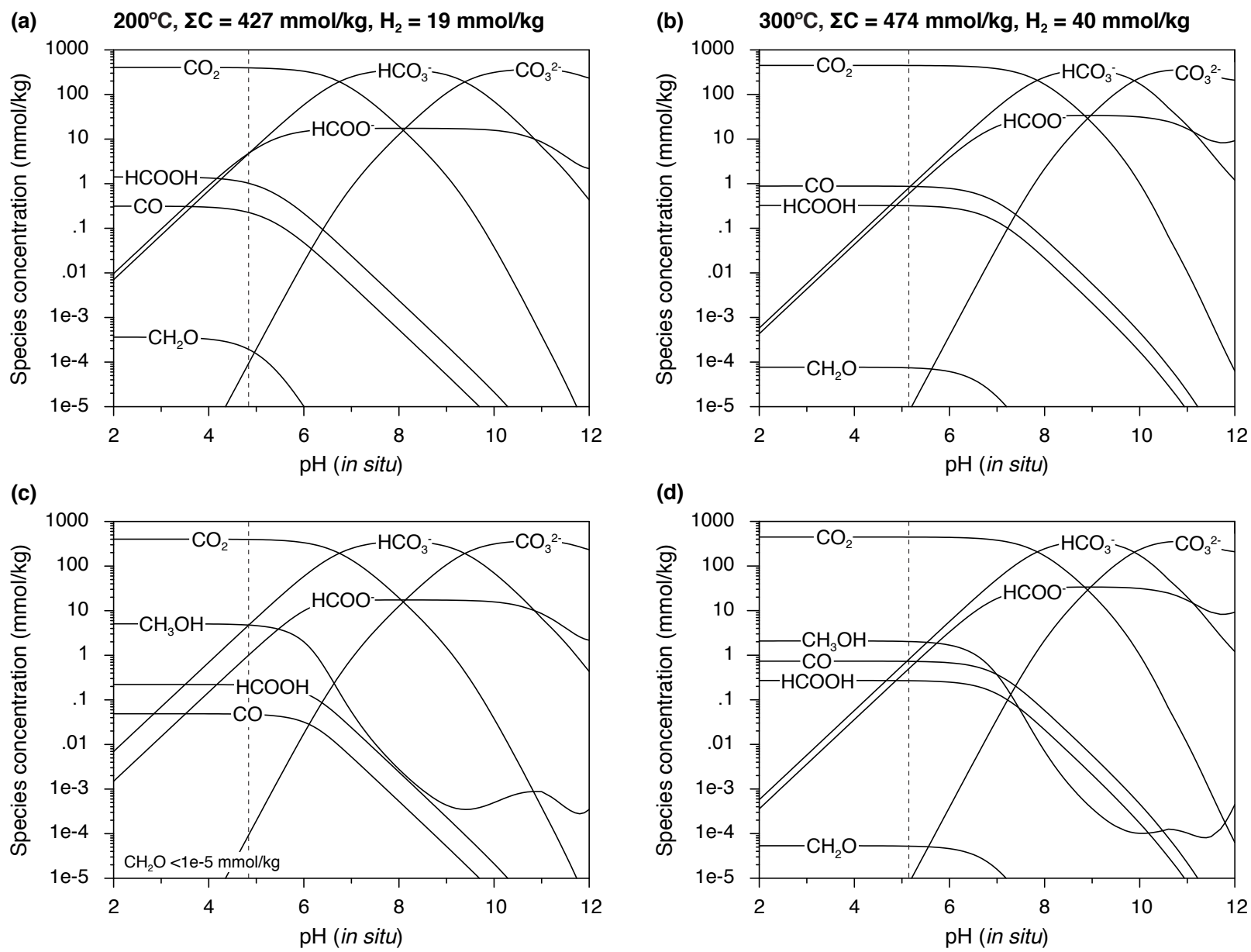

\section{Figure 3.9}

Calculated equilibrium concentrations of single carbon aqueous species as a function of $\mathrm{pH}$ for constant total carbon and $\mathrm{H}_{2(a q)}$ concentrations at $200^{\circ} \mathrm{C}(\mathrm{a}, \mathrm{c})$ and $300^{\circ} \mathrm{C}(\mathrm{b}, \mathrm{d}), 35 \mathrm{MPa}$. Total carbon and $\mathrm{H}_{2(a q)}$ concentrations at each temperature are equal to measured values in the first fluid sampled after the injection of $\mathrm{CO}_{2}$. Figures (a) and (b) assume metastable equilibrium among $\Sigma \mathrm{CO}_{2}, \mathrm{H}_{2(a q)}, \mathrm{CO}_{(a q)}$, $\mathrm{HCOOH}, \mathrm{HCOO}^{-}$, and $\mathrm{CH}_{2} \mathrm{O}$. Figures (c) and (d) allow $\mathrm{CH}_{3} \mathrm{OH}$ to equilibrate with $\Sigma \mathrm{CO}_{2}$, in addition to the species listed above. $\mathrm{CH}_{4(a q)}$ was excluded from all equilibrium assemblages due to kinetic barriers to its formation at the experimental conditions. Dashed vertical lines denote the in situ $\mathrm{pH}$ calculated for the first fluid sampled after the $\mathrm{CO}_{2}$ injection at each temperature. Note that $\mathrm{HCOO}^{-}$is the dominant $\Sigma$ formate species at the in situ $\mathrm{pH}$ of each carbonation experiment. 


\section{REFERENCES}

Allen D. E. and Seyfried W. E. J. (2003) Compositional controls on vent fluids from ultramafichosted hydrothermal systems at mid-ocean ridges: An experimental study at $400^{\circ} \mathrm{C}, 500$ bars. Geochim. Cosmochim. Acta 67, 1531-1542.

Alt J. C., Schwarzenbach E. M., Früh-Green G. L., Shanks W. C., Bernasconi S. M., Garrido C. J., Crispini L., Gaggero L., Padrón-Navarta J. A. and Marchesi C. (2013) The role of serpentinites in cycling of carbon and sulfur: Seafloor serpentinization and subduction metamorphism. Lithos 178, 40-54.

Andreani M., Luquot L., Gouze P., Godard M., Hoisé E. and Gibert B. (2009) Experimental study of carbon sequestration reactions controlled by the percolation of $\mathrm{CO}_{2}$-rich brine through peridotites. Environ. Sci. Technol. 43, 1226-1231.

Arvidson R. S. and Mackenzie F. T. (1997) Tentative kinetic model for dolomite precipitation rate and its application to dolomite distribution. Aquat. Geochemistry 2, 273--298.

Bach W., Rosner M., Jöns N., Rausch S., Robinson L. F., Paulick H. and Erzinger J. (2011) Carbonate veins trace seawater circulation during exhumation and uplift of mantle rock: Results from ODP Leg 209. Earth Planet. Sci. Lett. 311, 242-252.

Bach W., Klein F. and Jöns N. (2013) Metasomatism within the ocean crust. In Metasomatism and the Chemical Transformation of Rock (eds. D. E. Harlov and H. Austrheim). Springer Berlin Heidelberg. pp. 253-288.

Baines A. G., Cheadle M. J., John B. E., Grimes C. B., Schwartz J. J. and Wooden J. L. (2009) SHRIMP $\mathrm{Pb} / \mathrm{U}$ zircon ages constrain gabbroic crustal accretion at Atlantis Bank on the ultraslow-spreading Southwest Indian Ridge. Earth Planet. Sci. Lett. 287, 540-550.

Beinlich A., Plümper O., Hövelmann J., Austrheim H. and Jamtveit B. (2012) Massive serpentinite carbonation at Linnajavri, N-Norway. Terra Nov. 24, 446-455.

Berndt M. E., Allen D. E. and Seyfried W. E. J. (1996) Reduction of $\mathrm{CO}_{2}$ during serpentinization of olivine at $300^{\circ} \mathrm{C}$ and 500 bar. Geology $\mathbf{2 4}, 351-354$.

Bonatti E., Emiliani C., Ferrara G., Honnorez J. and Rydell H. (1974) Ultramafic-carbonate breccias from the equatorial Mid Atlantic Ridge. Mar. Geol. 16, 83-102.

Boschi C., Dini A., Dallai L., Ruggieri G. and Gianelli G. (2009) Enhanced $\mathrm{CO}_{2}$-mineral sequestration by cyclic hydraulic fracturing and Si-rich fluid infiltration into serpentinites at Malentrata (Tuscany, Italy). Chem. Geol. 265, 209-226.

Charlou J. L., Donval J. P., Fouquet Y., Jean-Baptiste P. and Holm N. (2002) Geochemistry of high $\mathrm{H}_{2}$ and $\mathrm{CH}_{4}$ vent fluids issuing from ultramafic rocks at the Rainbow hydrothermal field (36 14 'N, MAR). Chem. Geol. 191, 345-359.

Charlou J. L., Donval J. P., Konn C., Ondréas H., Fouquet Y., Jean-Baptiste P. and Fourré E. (2010) High production and fluxes of $\mathrm{H}_{2}$ and $\mathrm{CH}_{4}$ and evidence of abiotic hydrocarbon synthesis by serpentinization in ultramafic-hosted hydrothermal systems on the MidAtlantic Ridge. In Diversity Of Hydrothermal Systems On Slow Spreading Ocean Ridges (eds. P. A. Rona, C. W. Devey, J. Dyment, and B. J. Murton). American Geophysical Union, Washington, D. C. pp. 265-296.

Dabitzias S. G. (1980) Petrology and genesis of the Vavdos cryptocrystalline magnesite deposits, Chalkidiki Peninsula, northern Greece. Econ. Geol. 75, 1138-1151.

Daval D., Hellmann R., Martinez I., Gangloff S. and Guyot F. (2013) Lizardite serpentine dissolution kinetics as a function of $\mathrm{pH}$ and temperature, including effects of elevated $\mathrm{pCO}_{2}$. Chem. Geol. 351, 245-256. 
Dick H. J. B., Fisher R. L. and Bryan W. B. (1984) Mineralogic variability of the uppermost mantle along mid-ocean ridges. Earth Planet. Sci. Lett. 69, 88-106.

Drummond S. E. J. (1981) Boiling and Mixing of Hydrothermal Fluids: Chemical Effects on Mineral Precipitation. Ph.D. thesis, Pennsylvania State University.

Eickmann B., Bach W. and Peckmann J. (2009) Authigenesis of carbonate minerals in modern and Devonian ocean-floor hard rocks. J. Geol. 117, 307-323.

Foustoukos D. I. and Seyfried W. E. J. (2004) Hydrocarbons in hydrothermal vent fluids: The role of chromium-bearing catalysts. Science 304, 1002-1005.

Frost B. R. (1985) On the stability of sulfides, oxides, and native metals in serpentinite. J. Petrol. 26, 31-63.

Fu Q., Sherwood Lollar B., Horita J., Lacrampe-Couloume G. and Seyfried W. E. J. (2007) Abiotic formation of hydrocarbons under hydrothermal conditions: Constraints from chemical and isotope data. Geochim. Cosmochim. Acta 71, 1982-1998.

Gerdemann S. J., O’Connor W. K., Dahlin D. C., Penner L. R. and Rush H. (2007) Ex situ aqueous mineral carbonation. Environ. Sci. Technol. 41, 2587-2593.

Grimes C. B., John B. E., Cheadle M. J. and Wooden J. L. (2008) Protracted construction of gabbroic crust at a slow spreading ridge: Constraints from ${ }^{206} \mathrm{~Pb} /{ }^{238} \mathrm{U}$ zircon ages from Atlantis Massif and IODP Hole U1309D (30N, MAR). Geochemistry, Geophys. Geosystems 9, Q08012, doi:10.1029/2008GC002063.

Grimes C. B., Cheadle M. J., John B. E., Reiners P. W. and Wooden J. L. (2011) Cooling rates and the depth of detachment faulting at oceanic core complexes: Evidence from zircon $\mathrm{Pb} / \mathrm{U}$ and (U-Th)/He ages. Geochemistry, Geophys. Geosystems 12, Q0AG01, doi:10.1029/2010GC003391.

Harrison A. L., Power I. M. and Dipple G. M. (2013) Accelerated carbonation of brucite in mine tailings for carbon sequestration. Environ. Sci. Technol. 47, 126-134.

Hedderich R. and Whitman W. B. (2006) Physiology and biochemistry of the methaneproducing archaea. In The Prokaryotes, vol. 2 (eds. M. Dworkin, S. Falkow, E. Rosenberg, K. H. Stackebrandt, and E. Schleifer). Springer, New York. pp. 1050-1079.

Hentscher M. (2012) Thermodynamic investigations of microbial metabolism and abiotic organic synthesis in seafloor hydrothermal systems. Ph.D. thesis, University of Bremen.

Hövelmann J., Austrheim H., Beinlich A. and Munz I. A. (2011) Experimental study of the carbonation of partially serpentinized and weathered peridotites. Geochim. Cosmochim. Acta 75, 6760-6779.

Janecky D. R. and Seyfried W. E. J. (1986) Hydrothermal serpentinization of peridotite within the oceanic crust: Experimental investigations of mineralogy and major element chemistry. Geochim. Cosmochim. Acta 50, 1357-1378.

John B. E., Foster D. A., Murphy J. M., Cheadle M. J., Baines A. G., Fanning C. M. and Copeland P. (2004) Determining the cooling history of in situ lower oceanic crust-Atlantis Bank, SW Indian Ridge. Earth Planet. Sci. Lett. 222, 145-160.

Johnson J. W., Oelkers E. H. and Helgeson H. C. (1992) SUPCRT92: A software package for calculating the standard molal thermodynamic properties of minerals, gases, aqueous species, and reactions from 1 to 5000 bar and 0 to $1000^{\circ}$ C. Comput. Geosci. 18, 899-947.

Jonas L., Müller T., Dohmen R., Baumgartner L. and Putlitz B. (2015) Transport-controlled hydrothermal replacement of calcite by Mg-carbonates. Geology 43, 779-782.

Jones L. C., Rosenbauer R., Goldsmith J. I. and Oze C. (2010) Carbonate control of $\mathrm{H}_{2}$ and $\mathrm{CH}_{4}$ production in serpentinization systems at elevated P-Ts. Geophys. Res. Lett. 37, L14306, 
doi:10.1029/2010GL043769.

Kelemen P. B. and Matter J. M. (2008) In situ carbonation of peridotite for $\mathrm{CO}_{2}$ storage. Proc. Natl. Acad. Sci. 105, 17295-17300.

Kelemen P. B., Matter J., Streit E. E., Rudge J. F., Curry W. B. and Blusztajn J. (2011) Rates and mechanisms of mineral carbonation in peridotite: Natural processes and recipes for enhanced, in situ $\mathrm{CO}_{2}$ capture and storage. Annu. Rev. Earth Planet. Sci. 39, 545-576.

Kell-Duivestein I., Dietzel M., Baldermann A. and Mavromatis V. (2017) New insights to the formation of dolomite and magnesite through hydrothermal alteration of Ca-carbonates: An experimental approach. EGU Gen. Assem. Conf. Abstr. 19, 14116.

Kelley D. S. (1996) Methane-rich fluids in the oceanic crust. J. Geophys. Res. Earth 101, 29432962.

Kelley D. S. and Früh-Green G. L. (1999) Abiogenic methane in deep-seated mid-ocean ridge environments: Insights from stable isotope analyses. J. Geophys. Res. 104, 10,439-10,460.

Kelley D. S. and Früh-Green G. L. (2001) Volatile lines of descent in submarine plutonic environments: Insights from stable isotope and fluid inclusion analyses. Geochim. Cosmochim. Acta 65, 3325-3346.

Kelley D. S., Karson J. A., Früh-Green G. L., Yoerger D. R., Shank T. M., Butterfield D. A., Hayes J. M., Schrenk M. O., Olson E. J., Proskurowski G., Jakuba M., Bradley A., Larson B., Ludwig K., Glickson D., Buckman K., Bradley A. S., Brazelton W. J., Roe K., Bernasconi S. M., Elend M. J., Lilley M. D., Baross J. A., Summons R. E. and Sylva S. P. (2005) A serpentinite-hosted ecosystem: The Lost City hydrothermal field. Science 307, $1428-1434$.

Klein F. and Bach W. (2009) Fe-Ni-Co-O-S phase relations in peridotite-seawater interactions. $J$. Petrol. 50, 37-59.

Klein F. and Garrido C. J. (2011) Thermodynamic constraints on mineral carbonation of serpentinized peridotite. Lithos 126, 147-160.

Klein F. and McCollom T. M. (2013) From serpentinization to carbonation: New insights from a $\mathrm{CO}_{2}$ injection experiment. Earth Planet. Sci. Lett. 379, 137-145.

Klein F., Bach W., Jöns N., McCollom T., Moskowitz B. and Berquó T. (2009) Iron partitioning and hydrogen generation during serpentinization of abyssal peridotites from $15^{\circ} \mathrm{N}$ on the Mid-Atlantic Ridge. Geochim. Cosmochim. Acta 73, 6868-6893.

Klein F., Bach W. and McCollom T. M. (2013) Compositional controls on hydrogen generation during serpentinization of ultramafic rocks. Lithos 178, 55-69.

Klein F., Grozeva N. G., Seewald J. S., McCollom T. M., Humphris S. E., Moskowitz B., Berquó T. S. and Kahl W.-A. (2015a) Experimental constraints on fluid-rock reactions during incipient serpentinization of harzburgite. Am. Mineral. 100, 991-1002.

Klein F., Humphris S. E., Guo W., Schubotz F., Schwarzenbach E. M. and Orsi W. D. (2015b) Fluid mixing and the deep biosphere of a fossil Lost City-type hydrothermal system at the Iberia Margin. Proc. Natl. Acad. Sci. 112, 12036-12041.

Lang S. Q., Butterfield D. A., Schulte M., Kelley D. S. and Lilley M. D. (2010) Elevated concentrations of formate, acetate and dissolved organic carbon found at the Lost City hydrothermal field. Geochim. Cosmochim. Acta 74, 941-952.

Ludwig K. A., Kelley D. S., Butterfield D. A., Nelson B. K. and Früh-Green G. (2006) Formation and evolution of carbonate chimneys at the Lost City Hydrothermal Field. Geochim. Cosmochim. Acta 70, 3625-3645.

Malvoisin B., Carlut J. and Brunet F. (2012) Serpentinization of oceanic peridotites: 1. A high- 
sensitivity method to monitor magnetite production in hydrothermal experiments. $J$. Geophys. Res. 117, B01104, doi:10.1029/2011JB008612.

Martin B. and Fyfe W. S. (1970) Some experimental and theoretical observations on the kinetics of hydration reactions with particular reference to serpentinization. Chem. Geol. 6, 185202.

McCollom T. M. (2016) Abiotic methane formation during experimental serpentinization of olivine. Proc. Natl. Acad. Sci. 113, 13,965-13,970.

McCollom T. M. and Bach W. (2009) Thermodynamic constraints on hydrogen generation during serpentinization of ultramafic rocks. Geochim. Cosmochim. Acta 73, 856-875.

McCollom T. M. and Seewald J. S. (2001) A reassessment of the potential for reduction of dissolved $\mathrm{CO}_{2}$ to hydrocarbons during serpentinization of olivine. Geochim. Cosmochim. Acta 65, 3769-3778.

McCollom T. M. and Seewald J. S. (2003) Experimental constraints on the hydrothermal reactivity of organic acids and acid anions: I. Formic acid and formate. Geochim. Cosmochim. Acta 67, 3625-3644.

McCollom T. M. and Seewald J. S. (2007) Abiotic synthesis of organic compounds in deep-sea hydrothermal environments. Chem. Rev. 107, 382-401.

McCollom T. M., Lollar B. S., Lacrampe-Couloume G. and Seewald J. S. (2010) The influence of carbon source on abiotic organic synthesis and carbon isotope fractionation under hydrothermal conditions. Geochim. Cosmochim. Acta 74, 2717-2740.

McCollom T. M., Klein F., Robbins M., Moskowitz B., Berquó T. S., Jöns N., Bach W. and Templeton A. (2016) Temperature trends for reaction rates, hydrogen generation, and partitioning of iron during experimental serpentinization of olivine. Geochim. Cosmochim. Acta 181, 175-200.

McDermott J. M., Seewald J. S., German C. R. and Sylva S. P. (2015) Pathways for abiotic organic synthesis at submarine hydrothermal fields. Proc. Natl. Acad. Sci. 112, 7668-7672.

Michael P. J. and Bonatti E. (1985) Peridotite composition from the North Atlantic: Regional and tectonic variations and implications for partial melting. Earth Planet. Sci. Lett. 73, 91104.

O’Connor W. K., Dahlin D. C., Rush G. E., Gerdemann S. J. and Nilsen D. N. (2005) Aqueous mineral carbonation. US Dept. of Energy Final Report. DOE/ARC-TR-04-002. National Energy Technology Laboratory, US Dept of Energy, Albany, OR.

Okamoto A., Ogasawara Y., Ogawa Y. and Tsuchiya N. (2011) Progress of hydration reactions in olivine- $\mathrm{H}_{2} \mathrm{O}$ and orthopyroxenite- $\mathrm{H}_{2} \mathrm{O}$ systems at $250^{\circ} \mathrm{C}$ and vapor-saturated pressure. Chem. Geol. 289, 245-255.

Orlando A., Borrini D. and Marini L. (2011) Dissolution and carbonation of a serpentinite: Inferences from acid attack and high P-T experiments performed in aqueous solutions at variable salinity. Appl. Geochemistry 26, 1569-1583.

Oskierski H. C., Bailey J. G., Kennedy E. M., Jacobsen G., Ashley P. M. and Dlugogorski B. Z. (2013) Formation of weathering-derived magnesite deposits in the New England Orogen, New South Wales, Australia: Implications from mineralogy, geochemistry and genesis of the Attunga magnesite deposit. Miner. Depos. 48, 525-541.

Proskurowski G., Lilley M. D., Seewald J. S., Früh-Green G. L., Olson E. J., Lupton J. E., Sylva S. P. and Kelley D. S. (2008) Abiogenic hydrocarbon production at Lost City Hydrothermal Field. Science 319, 604-607.

Reeves E. (2010) Laboratory and field-based investigations of subsurface geochemical processes 
in seafloor hydrothermal systems. Ph.D. thesis, Massachusetts Institute of Technology.

Saccocia P. J., Seewald J. S. and Shanks W. C. (2009) Oxygen and hydrogen isotope fractionation in serpentine-water and talc-water systems from 250 to $450^{\circ} \mathrm{C}, 50 \mathrm{MPa}$. Geochim. Cosmochim. Acta 73, 6789-6804.

Saldi G. D., Schott J., Pokrovsky O. S., Gautier Q. and Oelkers E. H. (2012) An experimental study of magnesite precipitation rates at neutral to alkaline conditions and $100-200^{\circ} \mathrm{C}$ as a function of $\mathrm{pH}$, aqueous solution composition and chemical affinity. Geochim. Cosmochim. Acta 83, 93-109.

Schroeder T., Bach W., Jöns N., Jöns S., Monien P. and Klügel A. (2015) Fluid circulation and carbonate vein precipitation in the footwall of an oceanic core complex, Ocean Drilling Program Site 175, Mid-Atlantic Ridge. Geochemistry, Geophys. Geosystems 16, 37163732.

Schwartz J. J., John B. E., Cheadle M. J., Reiners P. W. and Baines A. G. (2009) Cooling history of Atlantis Bank oceanic core complex: Evidence for hydrothermal activity 2.6 Ma off axis. Geochemistry, Geophys. Geosystems 10, Q08020, doi:10.1029/2009GC002466.

Schwarzenbach E. M., Früh-Green G. L., Bernasconi S. M., Alt J. C. and Plas A. (2013) Serpentinization and carbon sequestration: A study of two ancient peridotite-hosted hydrothermal systems. Chem. Geol. 351, 115-133.

Seewald J. S., Zolotov M. Y. and McCollom T. (2006) Experimental investigation of single carbon compounds under hydrothermal conditions. Geochim. Cosmochim. Acta 70, 446460.

Seyfried W. E. J., Janecky D. R. and Berndt M. E. (1987) Rocking autoclaves for hydrothermal experiments, II. The flexible reaction-cell system. In Hydrothermal Experimental Techniques (eds. G. C. Ulmer and H. L. Barnes). John Wiley and Sons, New York, NY. pp. 216-239.

Seyfried W. E. J., Foustoukos D. I. and Fu Q. (2007) Redox evolution and mass transfer during serpentinization: An experimental and theoretical study at $200^{\circ} \mathrm{C}, 500$ bar with implications for ultramafic-hosted hydrothermal systems at mid-ocean ridges. Geochim. Cosmochim. Acta 71, 3872-3886.

Snow J. E. and Dick H. J. B. (1995) Pervasive magnesium loss by marine weathering of peridotite. Geochim. Cosmochim. Acta 59, 4219-4235.

van Noort R., Spiers C. J., Drury M. R. and Kandianis M. T. (2013) Peridotite dissolution and carbonation rates at fracture surfaces under conditions relevant for in situ mineralization of $\mathrm{CO}_{2}$. Geochim. Cosmochim. Acta 106, 1-24.

Von Damm K. L. (1995) Controls on the chemistry and temporal variability of seafloor hydrothermal fluids. In Seafloor Hydrothermal Systems: Physical, Chemical, Biological, and Geological Interactions (eds. S. E. Humphris, R. A. Zierenberg, L. S. Mullineaux, and R. E. Thomson). American Geophysical Union, Washington, D. C. pp. 222-247.

Whiteside J. H., Olsen P. E., Eglinton T. I., Cornet B., McDonald N. G. and Huber P. (2011) Pangean great lake paleoecology on the cusp of the end-Triassic extinction. Palaeogeogr. Palaeoclimatol. Palaeoecol. 301, 1-17.

Wolery T. J. (1992) EQ3/6, A Software Package for Geochemical Modeling of Aqueous Systems: Theoretical Manual, User's Guide, and Related Documentation (Version 7.0)., Lawrence Livermore National Laboratory.

Wolery T. J. and Jove-Colon C. F. (2004) Qualification of thermodynamic data for geochemical modeling of mineral-water interactions in dilute systems. No. ANL-WIS-GS-000003 REV 
00. Yucca Mountain Project, Las Vegas, Nevada.

Woods J. T. and Mellon M. G. (1941) The Molybdenum blue reaction: A spectrophotometric study. Ind. Eng. Chem. Anal. Ed. 13, 760-764.

Zhao L., Sang L., Chen J., Ji J. and Teng H. H. (2010) Aqueous carbonation of natural brucite: Relevance to $\mathrm{CO}_{2}$ sequestration. Environ. Sci. Technol. 44, 406-11. 


\title{
Chapter 4
}

\section{Isotopic analyses of methane- and ethane-bearing fluid inclusions in olivine- rich rocks: Implications for the origin of abiotic hydrocarbons in ultramafic- influenced hydrothermal systems}

\begin{abstract}
To better constrain the origin of abiotic hydrocarbons in the oceanic lithosphere and in ultramafic-influenced hydrothermal fluids, we examined the mineralogical, chemical, and isotopic compositions of fluid inclusions in olivine-rich basement rocks from two active serpentinization systems - the Von Damm hydrothermal field on the Mid-Cayman Rise and the Zambales ophiolite in the Philippines. Peridotite, troctolite, and gabbroic rocks in these systems contain abundant $\mathrm{CH}_{4}$-rich secondary inclusions in olivine, with less abundant inclusions in plagioclase and clinopyroxene. Raman spectroscopy reveals that olivine-hosted secondary inclusions are chiefly composed of $\mathrm{CH}_{4}$ and minor $\mathrm{H}_{2}$, in addition to secondary minerals including serpentine, brucite, magnetite, and carbonates. Secondary inclusions in plagioclase are dominated by $\mathrm{CH}_{4}$ with variable amounts of $\mathrm{H}_{2}$ and liquid $\mathrm{H}_{2} \mathrm{O}$, while those in clinopyroxene contain $\mathrm{CH}_{4}$ as the sole volatile component. We determined hydrocarbon abundances and stable isotope compositions by crushing whole rock samples and analyzing the released volatiles using gas chromatography-isotope ratio mass spectroscopy (GC-IRMS). Bulk rock gas analyses yielded appreciable amounts of $\mathrm{CH}_{4}$ and $\mathrm{C}_{2} \mathrm{H}_{6}$ in samples from the Mid-Cayman Rise (4-313 $\mathrm{nmol} / \mathrm{g} \mathrm{CH}_{4}$ and 0.02-0.99 $\mathrm{nmol} / \mathrm{g} \mathrm{C}_{2} \mathrm{H}_{6}$ ), with lesser amounts in the Zambales ophiolite (2-37 $\mathrm{nmol} / \mathrm{g} \mathrm{CH}_{4}$ and 0.004-0.082 $\mathrm{nmol} / \mathrm{g} \mathrm{C}_{2} \mathrm{H}_{6}$ ). Mafic and ultramafic rocks at Cayman exhibit $\delta^{13} \mathrm{C}_{\mathrm{CH}_{4}}$ values of $-16.7 \%$ to $-4.4 \%$ and $\delta^{13} \mathrm{C}_{\mathrm{C}_{2} \mathrm{H}_{6}}$ values of $-20.3 \%$ to $+0.7 \%$. Ultramafic rocks from Zambales exhibit $\delta^{13} \mathrm{C}_{\mathrm{CH}_{4}}$ values of $-12.4 \%$ o to $-2.8 \%$ and $\delta^{13} \mathrm{C}_{\mathrm{C}_{2} \mathrm{H}_{6}}$ values of -1.2\%o to $0.9 \%$. $\delta^{13} \mathrm{C}$ compositions for $\mathrm{CH}_{4}$ are significantly heavier than those measured in most oceanic plutonic rocks to date, but are similar to the range in $\mathrm{CH}_{4}$ isotopic composition observed in ultramafic-influenced mid-ocean ridge vent fluids. We propose that magmatic $\mathrm{CO}_{2}$ initially trapped in secondary inclusions underwent reduction by $\mathrm{H}_{2}$ to form $\mathrm{CH}_{4}$ and lesser quantities of
\end{abstract}


$\mathrm{C}_{2+}$ alkanes via Fisher-Tropsch-type reactions. Comparisons of isotopic compositions of $\mathrm{CH}_{4}$ and $\mathrm{C}_{2} \mathrm{H}_{6}$ with values from Von Damm hydrothermal fluids and Zambales gas seeps suggest that leaching of fluid inclusions may provide a significant contribution of hydrocarbons to actively circulating fluids in these systems. Similarity in the isotopic compositions of $\mathrm{CH}_{4}$ and $\mathrm{C}_{2} \mathrm{H}_{6}$ from a variety of hydrothermal fields hosted in olivine-rich rocks further supports the idea that a significant portion of abiotic hydrocarbons in ultramafic-influenced vent fluids may be derived from fluid inclusions. 


\section{INTRODUCTION}

Seawater-derived fluids venting from submarine hydrothermal systems provide a significant source of dissolved carbon and metabolic energy needed to support biological activity

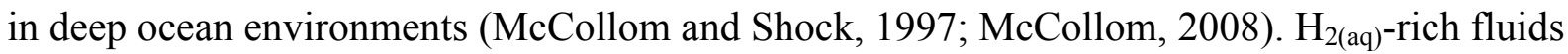
generated from active serpentinization systems have received particular attention for their potential to reduce dissolved inorganic carbon $\left(\Sigma \mathrm{CO}_{2}=\mathrm{CO}_{2}+\mathrm{HCO}_{3}{ }^{-}+\mathrm{CO}_{3}{ }^{2-}\right)$ to organic carbon compounds, including $\mathrm{CH}_{4}$ and longer-chain hydrocarbons (McCollom and Seewald, 2007). Evidence from stable isotope compositions and relative abundances supports an abiotic origin for these reduced carbon species (Charlou et al., 2002; Proskurowski et al., 2008; Charlou et al., 2010; Lang et al., 2010; McDermott et al., 2015).

One model for the formation of abiotic hydrocarbons in submarine hydrothermal systems involves the active reduction of dissolved $\Sigma \mathrm{CO}_{2}$ during circulation of seawater-derived hydrothermal fluids in the subseafloor (e.g., Charlou et al., 2002; Proskurowski et al., 2008; Charlou et al., 2010). However, recent analyses of vent fluids from the ultramafic-influenced Von Damm hydrothermal field at the Mid-Cayman Rise indicate that $\mathrm{CH}_{4(a q)}$ is not formed during active convection of serpentinizing fluids (McDermott et al., 2015). $\mathrm{CH}_{4(a q)}$ measured in Von Damm fluids is radiocarbon dead, whereas $\Sigma \mathrm{CO}_{2}$ contains detectable ${ }^{14} \mathrm{C}$, indicating that $\mathrm{CH}_{4}$ is not sourced from dissolved inorganic carbon in circulating fluids. In addition, dissolved $\Sigma \mathrm{CO}_{2}$ concentrations in Von Damm end-member fluids are nearly identical to those in local bottom seawater when corrected for $\mathrm{H}_{2} \mathrm{O}$ removal by mineral hydration reactions, suggesting that seawater $\Sigma \mathrm{CO}_{2}$ has been neither lost nor gained to any significant extent during active circulation of seawater through the crust. Conservation of $\Sigma \mathrm{CO}_{2}$ during subsurface fluid flow is further supported by the carbon isotopic composition of $\Sigma \mathrm{CO}_{2}$ in end-member fluids, which is identical within analytical error to that in bottom seawater. Addition of $2.81 \mathrm{mmol} / \mathrm{kg} \mathrm{CH}_{4(a q)}$ to endmember fluids at Von Damm, therefore, doubles the amount of carbon contained in circulating fluids relative to that of seawater, and points to a source of $\mathrm{CH}_{4}$ that is disconnected from reduction of $\Sigma \mathrm{CO}_{2}$ during active fluid convection. The lack of evidence for $\mathrm{CO}_{2}$ reduction to $\mathrm{CH}_{4}$ during active fluid flow is consistent with the strong kinetic barriers to abiotic $\mathrm{CH}_{4}$ synthesis under hydrothermal conditions, except where specific catalysts are present (McCollom and Seewald, 2001; McCollom and Seewald, 2003; Foustoukos and Seyfried, 2004; Seewald et al., 2006; Fu et al., 2007; McCollom et al., 2016). 
An alternative source of $\mathrm{CH}_{4}$ and potentially other low-molecular weight hydrocarbons involves leaching from carbon-bearing fluid inclusions hosted in plutonic rocks (Kelley, 1996; Kelley and Früh-Green, 1999; McCollom and Seewald, 2007; McDermott et al., 2015). According to this model, magmatic $\mathrm{CO}_{2}$ and $\mathrm{H}_{2} \mathrm{O}$ trapped within fluid inclusions undergo respeciation to $\mathrm{CH}_{4}$ and $\mathrm{C}_{2+}$ hydrocarbons upon cooling of the host rock on geologic time scales (Kelley and Früh-Green, 1999). $\mathrm{CH}_{4}$-rich fluid inclusions have been observed in plutonic rocks from the ultraslow-spreading Southwest Indian Ridge and are interpreted to be of abiotic origin (Kelley, 1996; Kelley and Früh-Green, 1999; Kelley and Früh-Green, 2001). $\delta^{13} \mathrm{C}_{\mathrm{CH}_{4}}$ values range from $-9 \%$ o to $-34 \%$ (Kelley and Früh-Green, 1999; Kelley and Früh-Green, 2001), consistent with values measured not only in Von Damm hydrothermal fluids, but also fluids venting from other ultramafic-influenced hydrothermal sites (Charlou et al., 2002; Proskurowski et al., 2008; Charlou et al., 2010). Despite growing evidence supporting an abiotic origin for dissolved hydrocarbons in submarine hydrothermal systems, the physical conditions, reaction mechanisms, and timescales of abiotic organic synthesis remain poorly constrained.

The purpose of this study was to test whether abiotic $\mathrm{CH}_{4}$ and $\mathrm{C}_{2} \mathrm{H}_{6}$ in fluids venting from ultramafic-influenced hydrothermal systems could be derived from the leaching of carbonbearing fluid inclusions hosted in olivine-rich rocks. We analyzed the relative abundances and isotopic compositions of hydrocarbons in mafic and ultramafic rocks from the Mount Dent oceanic core complex hosting the Von Damm hydrothermal field. In addition, we analyzed fluid inclusions in ultramafic rocks from the Zambales ophiolite, a continental serpentinization system located in the Philippines. $\mathrm{CH}_{4}$ gas emanating from the ophiolite contains $<1 \%$ modern $\mathrm{C}$ according to radiocarbon measurements (Abrajano et al., 1990), indicating that $\mathrm{CH}_{4}$ is not being actively formed from $\Sigma \mathrm{CO}_{2}$ in meteoric fluids. Similar to the Von Damm hydrothermal field, $\mathrm{CH}_{4}$ at Zambales may also be derived from hydrocarbons trapped in the ultramafic protolith (Abrajano et al., 1988). This study compares the measured hydrocarbon abundances and isotopic signatures in fluid inclusions to values from Von Damm vent fluids and Zambales gas seeps to directly constrain the source of hydrocarbons in active serpentinization systems. 


\section{MATERIALS AND METHODS}

\subsection{Sample materials}

Seven olivine-rich plutonic and mantle rocks from the Mid-Cayman Rise were acquired from the Seafloor Samples Laboratory at Woods Hole Oceanographic Institution. Samples were recovered using the deep submergence vehicle Alvin during the Cayman Trough Project in 1976 (Ballard et al., 1979; Stroup and Fox, 1981). Samples were collected 4-6 km from the Von Damm hydrothermal field, on the eastern flank of the Mount Dent oceanic core complex, and include one gneissic metagabbro (ALV 620-3C), two olivine gabbros (ALV 620-5-1, ALV-624 5-1), two troctolites (ALV 621-3-1, ALV 623-3-2), one serpentinized spinel harzburgite (ALV 624-3-3), and one serpentinized spinel lherzolite (ALV 624-6-2) (Stroup and Fox, 1981). Locations of individual samples analyzed in this study are shown in Figure 4.1. Detailed descriptions of the mineralogical and chemical compositions of each sample are presented in previous works (Malcolm, 1979; Stroup and Fox, 1981; Elthon, 1987).

Four samples of ultramafic rock were acquired from the Zambales ophiolite in the Philippines. Two serpentinized dunites (ZMCR-02 and ZMCR-03) were collected from the Coto Mine, a chromite mine in the Zambales Mineral Chromite Reservation (N 15³4' 21.0", E $\left.120^{\circ} 05^{\prime} 47.9^{\prime \prime}\right)$. Two serpentinized harzburgites (NSS-02 and NSS-04) were collected from Nagsasa Cove in San Antonio, Philippines (N 14 49' 41.1", E $120^{\circ} 7^{\prime}$ 3.2"). Sampling locations are shown in Figure 4.2. All samples were collected $\sim 5 \mathrm{~km}$ from $\mathrm{CH}_{4}$-rich gas seeps in the Zambales ophiolite. Rocks samples from both the Mid-Cayman Rise and Zambales ophiolite exhibit variable degrees of alteration.

\subsection{Analytical methods}

Thin sections of rock samples were examined with a petrographic microscope in transmitted and reflected light to document the types, sizes, and distribution of fluid inclusions. A Horiba Jobin-Yvon LabRAM HR confocal Raman spectrometer with a $473 \mathrm{~nm}$ laser, $600 \mathrm{~mm}^{-}$ ${ }^{1}$ grating, $100 \mu \mathrm{m}$ confocal hole, and $100 \mu \mathrm{m}$ slit width was used to identify the volatile contents of individual inclusions and the mineralogy of the inclusion walls. Spectra represent the average of at least three 30-120 s acquisitions typically conducted in the $150-2300 \mathrm{~cm}^{-1}$ and $2750-4400$ $\mathrm{cm}^{-1}$ regions. Preliminary estimates of $\mathrm{CH}_{4}$ vapor densities and pressures in fluid inclusions of select samples were determined from the measured Raman shift of the $\mathrm{C}-\mathrm{H}$ symmetric stretching 
band relative to the band position of pure methane at $21^{\circ} \mathrm{C}$ and near zero density. Raman spectra for quantitative $\mathrm{CH}_{4}$ measurements were acquired using a $473 \mathrm{~nm}$ laser, $1800 \mathrm{~mm}^{-1}$ grating, and $100 \mu \mathrm{m}$ slit width. $\mathrm{CH}_{4}$ vapor densities were then calculated using the calibration of Zhang et al. (2016), and $\mathrm{CH}_{4}$ pressures were calculated using the calibration of $\mathrm{Lu}$ et al. (2007). Detection limits for Raman spectroscopy are instrument-specific and depend on the measurement conditions, which can vary from sample to sample and even within individual mineral grains. For instance, while it is possible to detect $\mathrm{CO}_{2(\mathrm{~g})}$ with a density of $0.001-0.002 \mathrm{~g} / \mathrm{cm}^{3}$ in large $(>10$ $\mu \mathrm{m}$ ) fluid inclusions near the surface (Wopenka and Pasteris, 1987; Rosso and Bodnar, 1995; Lamadrid, 2016), higher vapor densities are needed to detect $\mathrm{CO}_{2(g)}$ in smaller inclusions or those buried deep in the mineral host. Wopenka and Pasteris (1987) have reported detection limits for $\mathrm{CH}_{4(\mathrm{~g})}\left(0.0002 \mathrm{~g} / \mathrm{cm}^{3}\right)$ and $\mathrm{H}_{2(\mathrm{~g})}\left(0.0001 \mathrm{~g} / \mathrm{cm}^{3}\right)$ that are an order of magnitude lower than that for $\mathrm{CO}_{2(g)}$. Although detection limits reported in the literature apply only to the specific analytical conditions used to derive them (e.g., laser power, confocal hole diameter, slit size, detector type), they provide a rough estimate for the sensitivity of Raman spectroscopic techniques used in the present study.

For gas extraction measurements, rock samples were cut into $\mathrm{cm}$-sized pieces using a diamond-tipped blade to remove alteration rims, partially crushed using a tungsten-carbide jaw crusher, and then dry sieved to collect the $1-5 \mathrm{~mm}$ size fraction. Since olivine grains were partially to strongly altered in all samples, it was not feasible to fully separate them from secondary mineral products and collect olivine separates. Therefore, whole rock chips were used for all gas analyses.

Hydrocarbon gases were extracted by mechanical crushing, and analyzed for stable isotopic compositions $\left(\delta^{13} \mathrm{C}_{\mathrm{CH}_{4}}, \delta^{13} \mathrm{C}_{\mathrm{C}_{2} \mathrm{H}_{6}}\right)$ and relative abundances by gas chromatographyisotope ratio mass spectroscopy (GC-IRMS). Unlike other extraction techniques, such as thermal decrepitation, crushing liberates gases only from inclusions and does not result in thermal decomposition and chemical re-equilibration that can alter gas compositions (Piperov and Penchev, 1973; Roedder, 1984; Salvi and Williams-Jones, 2003). For instance, thermal decrepitation methods have been shown to generate $\mathrm{CO}_{2}, \mathrm{CO}$, and $\mathrm{CH}_{4}$ by pyrolysis of organic material (e.g., Piperov and Penchev, 1973; Norman and Sawkins, 1987; Norman et al., 1991). However, crushing also has several disadvantages, including lower extraction efficiency due to incomplete crushing, adsorption of gases onto newly-formed mineral surfaces, and production of 
gases by frictional heating (Abell et al., 1970; Roedder, 1972; Andrawes and Gibson, 1979; Andrawes et al., 1984; Welhan, 1988).

A 1-4 g aliquot of each sample was pulverized in a gas-tight, magnetically-operated, stainless steel crushing device under an atmosphere of helium (Figure 4.3). Samples were first loaded into the stainless steel cylinder, which was then sealed with a copper gasket. The crushing device was heated to $70^{\circ} \mathrm{C}$ during all steps of the analysis to reduce adsorption of gases onto mineral surfaces and facilitate their release into the carrier gas. Temperature was monitored using a thermocouple, and was well below temperatures required for pyrolysis of organic matter. The volume of the crushing device was initially purged 20 times with helium to remove atmospheric gases. The crushing device was then isolated from the helium flow path via a 4-port valve. A stainless steel ball inside the crushing device was manually raised and lowered 800 times using a magnet to pulverize the sample. Finally, the volume of the crushing device was sparged 10 times, and the released volatiles were focused onto a cryogenic trap immersed in liquid $\mathrm{N}_{2}$. The cryogenic trap was interfaced directly to an Agilent 6890 gas chromatograph (GC) coupled to a Thermo-Finnigan Delta Plus XL mass spectrometer (MS). A Poraplot-Q capillary column was used to separate hydrocarbon compounds in the $\mathrm{GC}$ prior to combustion at $1080^{\circ} \mathrm{C}$ and isotope ratio monitoring mass spectrometry. Stable carbon isotope values are reported in standard $\delta$-notation relative to the Vienna Pee Dee Belemnite as follows:

$\delta^{13} \mathrm{C}(\% o)=\left[\frac{R_{s p l}-R_{s t d}}{R_{s t d}}\right] \times 1000$,

where $\mathrm{R}_{\mathrm{spl}}$ and $\mathrm{R}_{\mathrm{std}}$ are the carbon isotope ratios $\left({ }^{13} \mathrm{C} /{ }^{12} \mathrm{C}\right)$ of the sample and standard, respectively. Samples ALV 620-5-1 and 620-5-1 were too $\mathrm{C}_{2} \mathrm{H}_{6}$-rich to allow for an analysis after 800 crushes. Therefore, each sample aliquot was crushed in 3-4 steps to achieve 800 total crushes, and an analysis was performed after each crushing step. Average $\delta^{13} \mathrm{C}_{\mathrm{C}_{2} \mathrm{H}_{6}}$ values for each aliquot were obtained by calculating a weighted mean of the individual analyses.

Average hydrocarbon abundances and carbon isotopic compositions for each sample were obtained from analyses of 2-5 aliquots of the bulk sample material. Prior to analyzing a new aliquot of the same sample, the previously crushed aliquot was removed from the bottom of the crushing device through mechanical agitation. However, no attempts were made to remove 
sample material that had adhered to the stainless steel ball or to the inside walls of the crushing device. This was done to minimize hydrocarbon contamination from the crushing device by reducing steel-to-steel contact during the crushing process. In between analyses of different samples, the crushing device was cleaned by scrubbing with a plastic brush to remove all rock powder, followed by sonication in water for 10 minutes. The crushing device was then triply rinsed in deionized water and dried in air atmosphere at $60^{\circ} \mathrm{C}$.

Helium abundances and isotopic compositions were analyzed by crushing in vacuum at the Isotope Geochemistry Facility at Woods Hole Oceanographic Institution. Whole rock chips were dry sieved to collect the $1-2 \mathrm{~mm}$ size fraction. The chips were then sonicated in distilled water followed by acetone, and dried in a laminar flow hood under air atmosphere. Approximately $0.3 \mathrm{~g}$ of sample was loaded into an ultra-high vacuum crusher (Kurz et al., 1987), and crushed 20 times using a magnetic stainless steel piston operated by three electromagnets. All helium measurements were performed using a branch tube magnetic sector mass spectrometer, details of which can be found in Kurz et al. (2004). Measured ${ }^{3} \mathrm{He} /{ }^{4} \mathrm{He}$ ratios are normalized to the atmospheric ${ }^{3} \mathrm{He} /{ }^{4} \mathrm{He}$ ratio, $\mathrm{R}_{\mathrm{a}}\left(1.4 \times 10^{-6}\right)$.

\subsection{Blank production of hydrocarbons}

Crushing rocks in steel crushers is known to generate gases, including $\mathrm{H}_{2}, \mathrm{CO}, \mathrm{CH}_{4}$, and $\mathrm{C}_{2+}$ hydrocarbons, from frictional heating that occurs during steel-steel contact (Abell et al., 970; Roedder, 1972; Andrawes and Gibson, 1979; Andrawes et al., 1984; Welhan, 1988). However, blank levels may be reduced by the presence of sample material which can cushion contact between metal surfaces (Welhan, 1988). Blank experiments performed in this study revealed that shaking the stainless steel ball inside an empty crushing device generated measureable quantities of $\mathrm{CH}_{4}$ and $\mathrm{C}_{2} \mathrm{H}_{6}$ that increased with the duration of shaking. This hydrocarbon contamination was minimized by using a large sample size (1-4 g) to reduce contact between the stainless steel ball and inner walls of the crushing chamber. To quantify the blank fraction in the gas analyses, blank measurements were performed using two different materials: (1) three previously pulverized samples (ALV 621-3-1, 623-3-2, 624-3-3) that were combusted at $1000^{\circ} \mathrm{C}$ in air atmosphere for $24 \mathrm{hr}$, and (2) $3 \mathrm{~mm}$-diameter combusted Pyrex beads. A $2 \mathrm{~g}$ fraction of each blank material was crushed and analyzed using the same procedure as described for the samples. Crushing of combusted samples generated $\leq 1 \%$ of $\mathrm{CH}_{4}$ and $\mathrm{C}_{2} \mathrm{H}_{6}$ produced from their respective 
uncombusted samples (Table 4.1). Crushing of combusted Pyrex beads yielded $\mathrm{CH}_{4}$ and $\mathrm{C}_{2} \mathrm{H}_{6}$ quantities of no more than $0.10 \mathrm{nmol} / \mathrm{g}$ and $0.0017 \mathrm{nmol} / \mathrm{g}$, respectively. This $\mathrm{CH}_{4}$ background represents $<0.1 \%$ of the $\mathrm{CH}_{4}$ yield from the most hydrocarbon-rich sample, ALV 620-3C, and $<6 \%$ of the $\mathrm{CH}_{4}$ yield from the least hydrocarbon-rich sample, ZMCR-03. The $\mathrm{C}_{2} \mathrm{H}_{6}$ background represents $<0.2 \%$ of the yield from the most $\mathrm{C}_{2} \mathrm{H}_{6}$-rich sample, ALV $620-3 \mathrm{C}$, and $<4 \%$ of the yield from the least $\mathrm{C}_{2} \mathrm{H}_{6}$-rich sample for which $\delta^{13} \mathrm{C}_{\mathrm{C}_{2} \mathrm{H}_{6}}$ values were obtained (ALV 623-3-2).

Hydrocarbon abundances and carbon isotopic compositions for each sample represent average values obtained from 2-5 replicate analyses. $\delta^{13} \mathrm{C}$ compositions of $\mathrm{CH}_{4}$ were identical within analytical error $\left( \pm 0.5 \%\right.$ ) among replicate analyses of the same sample. However, $\mathrm{C}_{2} \mathrm{H}_{6}$ was distinctly more ${ }^{13} \mathrm{C}$-depleted in the first aliquot analyzed for all samples, except for the most $\mathrm{C}_{2} \mathrm{H}_{6}$-rich sample, ALV 620-3C, which showed consistent $\delta^{13} \mathrm{C}_{\mathrm{C}_{2} \mathrm{H}_{6}}$ values among all replicate analyses. The remaining samples showed a trend toward more ${ }^{13} \mathrm{C}$-enriched $\delta^{13} \mathrm{C}_{\mathrm{C}_{2} \mathrm{H}_{6}}$ with analysis of successive aliquots of sample material (Figure 4.4). Shaking the stainless steel ball inside an empty crushing device yielded carbon isotopic compositions for $\mathrm{CH}_{4}\left(-36 \%\right.$ ) and $\mathrm{C}_{2} \mathrm{H}_{6}$ $(-29 \%)$ that were significantly more ${ }^{13} \mathrm{C}$-depleted than sample measurements, suggesting that the lighter $\mathrm{C}_{2} \mathrm{H}_{6}$ isotopic values obtained from the first sample aliquots reflect contamination from the crushing device. While analysis of the first sample aliquot was conducted in a clean crushing device free of any rock powder, analyses of subsequent aliquots were performed in the crushing device lined with previously powdered sample material. The presence of rock powder likely cushioned contact between the stainless steel ball and walls of the crushing chamber, thereby minimizing frictional heating during crushing. In conclusion, it appears that the observed trend in $\mathrm{C}_{2} \mathrm{H}_{6}$ isotopic composition with successive analysis of new sample material can be attributed to the production of isotopically light $\mathrm{C}_{2} \mathrm{H}_{6}$ from the crushing device. A similar trend in $\mathrm{CH}_{4}$ isotopic composition was not observed, likely because the amount of $\mathrm{CH}_{4}$ in the samples far exceeded blank levels.

$\delta^{13} \mathrm{C}_{\mathrm{C}_{2} \mathrm{H}_{6}}$ values for most samples from the Mid-Cayman Rise and Zambales ophiolite appeared to level off after analysis of the second or third aliquot of sample material (Figure 4.4). Average $\mathrm{C}_{2} \mathrm{H}_{6}$ isotope compositions of these samples were obtained from 2-4 successive analyses, whose $\delta^{13} \mathrm{C}_{\mathrm{C}_{2} \mathrm{H}_{6}}$ values are identical within analytical error $( \pm 0.5 \%)$. However, $\mathrm{C}_{2} \mathrm{H}_{6}$ isotopic compositions of two samples (ALV 624-5-1 and ALV 623-3-2) did not appear to clearly level off. Visual inspection revealed that these samples did not stick effectively to the stainless 
steel surfaces of the crushing device upon pulverization. Coating of walls with rock powder is expected to cushion steel-steel contact and reduce frictional heating during crushing (Welhan, 1988). Therefore, $\mathrm{C}_{2} \mathrm{H}_{6}$ isotope compositions of samples ALV 624-5-1 and ALV 623-3-2 appear to be more affected by hydrocarbon contamination from the crushing device, and measured $\delta^{13} \mathrm{C}_{\mathrm{C}_{2} \mathrm{H}_{6}}$ values likely reflect minima. ALV 624-5-1 and ALV 623-3-2 are relatively fresh and have a lower degree of alteration relative to the other samples. We speculate that the presence of abundant hydrous alteration minerals, including serpentine, talc, and tremolite, in the remaining samples produces a "stickier" rock powder that can adhere more effectively to the stainless steel walls of the crushing device, helping to minimize the production of hydrocarbons from frictional heating.

\section{RESULTS}

\subsection{Distribution of secondary fluid inclusions}

Secondary fluid inclusions occur as trails of inclusions along healed microfractures in a mineral (Figure 4.5). Inclusion trails are also observed to cross grain boundaries and span two different mineral hosts. Olivine contains the highest density of secondary fluid inclusions in all rock types analyzed. Olivine-hosted secondary inclusions are particularly abundant in metagabbro, olivine gabbro, and troctolite, with significantly fewer observed in serpentinized peridotite and dunite. They range in size from $<1$ to $25 \mu \mathrm{m}$, with most inclusions being $1-15 \mu \mathrm{m}$ in diameter. Plagioclase-hosted secondary inclusions are typically smaller in size, usually 1-10 $\mu \mathrm{m}$ but ranging up to $25 \mu \mathrm{m}$ in diameter, and are much less abundant than those in olivine. Inclusion trails within plagioclase are common in gabbro and troctolite, except for the gneissic metagabbro (ALV 620-3C), which has undergone extensive metamorphism. In contrast, this sample contains abundant secondary inclusions in hornblende. Few fluid inclusions are observed in clinopyroxene within any lithology.

\subsection{Composition of secondary fluid inclusions}

\subsubsection{Cayman}

A summary of the composition of secondary fluid inclusions is presented in Table 4.2. In situ Raman analyses of Cayman samples demonstrate that $\mathrm{CH}_{4}$-bearing inclusions occur as 
vapor-rich secondary inclusions in olivine, plagioclase, clinopyroxene, and hornblende. No $\mathrm{CO}_{2(g)}$, was detected by Raman spectroscopy in any secondary inclusion.

Olivine-hosted secondary fluid inclusions in all samples are dominated by $\mathrm{CH}_{4(g)}$, with minor $\mathrm{H}_{2(g)}$ (Figure 4.6). Preliminary data from sample ALV 624-3-3 yield estimated $\mathrm{CH}_{4(g)}$ vapor densities of 0.16-0.29 $\mathrm{g} / \mathrm{cm}^{3}$ (Zhang et al., 2016) and pressures of 20-54 MPa (Lu et al., 2007).as determined by measured Raman shifts of the $\mathrm{CH}_{4(g)}$ band position. Alteration minerals are commonly detected by Raman spectroscopy, and typically occur as spatially discrete phases lining the inside walls of fluid inclusions as shown by two-dimensional Raman mapping (Figure 4.7). Brucite and serpentine minerals, including chrysotile, lizardite, and antigorite, are observed in olivine-hosted inclusions within all Cayman samples. Magnetite and carbonate minerals, including calcite, high-Mg calcite, dolomite, and magnesite, additionally occur in olivine-hosted inclusions in most samples. No magnetite was detected in samples ALV 620-3C and 624-6-2, and no carbonates were detected in samples ALV 620-3C, 624-3-3, and 624-6-2. Free $\mathrm{H}_{2} \mathrm{O}$ was not observed, either as a liquid or vapor phase, in any olivine-hosted secondary inclusion by Raman spectroscopy.

Secondary fluid inclusions in plagioclase grains are vapor- and liquid-rich, hosting gaseous $\mathrm{CH}_{4}$ with variable amounts of liquid $\mathrm{H}_{2} \mathrm{O}$ (Figures 4.7 and 4.8). Secondary inclusions in samples ALV 620-5-1, 621-3-1, and 623-3-3 additionally contain minor $\mathrm{H}_{2(g)}$. Calcite and paragonite are common minerals in plagioclase-hosted secondary inclusions. Shortite $\left[\mathrm{Na}_{2} \mathrm{Ca}_{2}\left(\mathrm{CO}_{3}\right)_{3}\right]$, a sodium-calcium carbonate, was identified by Raman spectroscopy in one plagioclase-hosted secondary inclusion in sample ALV 620-5-1.

Raman measurements reveal that secondary fluid inclusions in clinopyroxene are vapordominated, with $\mathrm{CH}_{4}$ as the sole volatile component (Figure 4.9). High-Mg calcite was identified in the gneissic metagabbro sample ALV 620-3C. Tremolite-actinolite was detected in all samples, except ALV 624-5-1, on the basis of Raman band positions at $3677 \mathrm{~cm}^{-1}$ and $3662 \mathrm{~cm}^{-1}$ (Figure 4.9), with additional bands at lower wavenumbers $\left(3645 \mathrm{~cm}^{-1}, 3626 \mathrm{~cm}^{-1}\right)$ occurring in some samples.

\subsubsection{Zambales}

Olivine-hosted secondary fluid inclusions in ultramafic rocks from the Zambales ophiolite contain variable amounts of gaseous $\mathrm{CH}_{4}$ and $\mathrm{H}_{2}$ (Table 4.2). Raman measurements 
reveal that $\mathrm{H}_{2(g)}$ is the dominant volatile component within olivine-hosted secondary inclusions in samples ZMCR-02 and ZMCR-03. Minor $\mathrm{CH}_{4(g)}$ was additionally detected in ZMCR-02, but was not detected in ZMCR-03. Samples NSS-2 and NSS-04, in contrast, host more abundant $\mathrm{CH}_{4(g)}$ with minor $\mathrm{H}_{2(g)}$. Preliminary Raman data from olivine-hosted inclusions in NSS-04 yield estimated $\mathrm{CH}_{4(g)}$ vapor densities of $\leq 0.09 \mathrm{~g} / \mathrm{cm}^{3}$ (Zhang et al., 2016) and pressures of $\leq 11 \mathrm{MPa}$ (Lu et al., 2007). Olivine in all Zambales samples hosts brucite and serpentine minerals, including chrysotile, lizardite, and antigorite. Dolomite was also detected in some olivine-hosted secondary inclusions in sample NSS-04.

\subsection{Hydrocarbon abundances and isotopes}

A summary of the hydrocarbon gas data is presented in Table 4.3. All hydrocarbon abundances and isotopic compositions were obtained from whole rock samples crushed 800 times each. No correlations were observed between carbon isotopic compositions and hydrocarbon abundances or $\mathrm{CH}_{4} / \mathrm{C}_{2} \mathrm{H}_{6}$ ratios. Note that hydrocarbon abundances represent minimum values since it is impossible to break open all inclusions through crushing.

\subsubsection{Cayman}

Olivine-rich mafic and ultramafic rocks from the Mid-Cayman Rise show a wide range in hydrocarbon abundances and isotopic compositions (Table 4.3). Sample ALV 620-3C has the greatest absolute abundance of hydrocarbons, with average $\mathrm{CH}_{4}$ and $\mathrm{C}_{2} \mathrm{H}_{6}$ contents of 313 $\mathrm{nmol} / \mathrm{g}$ and $0.99 \mathrm{nmol} / \mathrm{g}$, respectively, while sample ALV 624-3-3 has the lowest quantity of hydrocarbons, with average $\mathrm{CH}_{4}$ and $\mathrm{C}_{2} \mathrm{H}_{6}$ contents of $4.3 \mathrm{nmol} / \mathrm{g}$ and $0.015 \mathrm{nmol} / \mathrm{g}$, respectively. $\mathrm{CH}_{4} / \mathrm{C}_{2} \mathrm{H}_{6}$ ratios of most Cayman samples fall between 315 and 924 . However, ALV 623-3-2 exhibits a much higher $\mathrm{CH}_{4} / \mathrm{C}_{2} \mathrm{H}_{6}$ ratio of 1372 relative to the remaining samples. $\delta^{13} \mathrm{C}$ isotopic compositions of $\mathrm{CH}_{4}$ similarly span a wide range of values, from $-4.4 \%$ to $-16.7 \%$. Serpentinized peridotite samples from Cayman contained insufficient $\mathrm{C}_{2} \mathrm{H}_{6}$ for measurement of $\delta^{13} \mathrm{C}_{\mathrm{C}_{2} \mathrm{H}_{6}}$. Most of the remaining Cayman samples exhibit $\delta^{13} \mathrm{C}_{\mathrm{C}_{2} \mathrm{H}_{6}}$ values from - $10.6 \%$ o to 20.3\%o. However, sample ALV 620-5-1 shows extremely ${ }^{13} \mathrm{C}$-enriched $\mathrm{C}_{2} \mathrm{H}_{6}$, with an average carbon isotopic composition of $+0.7 \%$. ALV 620-5-1 was very $\mathrm{C}_{2} \mathrm{H}_{6}$-rich relative to most samples. Thus, each sample aliquot had to be crushed in 3-4 steps, with an analysis performed after each crushing step. ALV 620-5-1 exhibited a trend toward more ${ }^{13} \mathrm{C}$-enriched $\mathrm{C}_{2} \mathrm{H}_{6}$ with 
increasing number of crushes, suggesting that there were distinct populations of fluid inclusions in the sample. However, no clear trend was evident in the $\mathrm{CH}_{4}$ isotopic composition or $\mathrm{CH}_{4} / \mathrm{C}_{2} \mathrm{H}_{6}$ ratio with cumulative number of crushes.

\subsubsection{Zambales}

Serpentinized dunite and peridotite from the Zambales ophiolite show a wide range in hydrocarbon abundances and isotopic compositions (Table 4.3). Samples ZMCR-02 and ZMCR03 have higher average $\mathrm{CH}_{4}$ contents $(23-37 \mathrm{nmol} / \mathrm{g})$ and $\mathrm{C}_{2} \mathrm{H}_{6}$ contents $(0.075-0.082 \mathrm{nmol} / \mathrm{g})$ relative to NSS-02 and NSS-04 (1.7-2.0 nmol/g CH 4 and 0.004-0.013 nmol $\left./ \mathrm{g} \mathrm{C}_{2} \mathrm{H}_{6}\right)$. Yet, all samples exhibit a relatively narrow range in average $\mathrm{CH}_{4} / \mathrm{C}_{2} \mathrm{H}_{6}$ ratios, from 163 to 431 . Samples ZMCR-02 and ZMCR-03 exhibit average $\delta^{13} \mathrm{C}_{\mathrm{CH}_{4}}$ values of $-10.9 \%$ to $-12.4 \%$. They contained insufficient $\mathrm{C}_{2} \mathrm{H}_{6}$ to obtain accurate $\delta^{13} \mathrm{C}$ values for $\mathrm{C}_{2} \mathrm{H}_{6}$. In contrast, samples NSS-02 and NSS04 exhibit more ${ }^{13} \mathrm{C}$-enriched $\mathrm{CH}_{4}$, with $\delta^{13} \mathrm{C}_{\mathrm{CH}_{4}}$ values of $-2.8 \%$ to $-3.0 \%$. The resulting carbon isotopic compositions for $\mathrm{C}_{2} \mathrm{H}_{6}$ are slightly ${ }^{13} \mathrm{C}$-enriched relative to corresponding $\mathrm{CH}_{4}$ isotopic compositions, and show average values of -0.9 to $-1.2 \%$.

\subsection{Helium contents and isotopes}

\subsubsection{Cayman}

A summary of the helium data is presented in Table 4.4. ${ }^{4} \mathrm{He}$ contents of Cayman samples exhibit a wide range from $4.7 \times 10^{-7}$ to $9.0 \times 10^{-11} \mathrm{~cm}^{3} \mathrm{STP} / \mathrm{g}$. Samples of serpentinized peridotite contain the lowest abundance of $\mathrm{He}$, with ${ }^{4} \mathrm{He}$ contents that are 1-2 orders of magnitude lower than those in plutonic rock samples. With the exception of the highest helium abundance in the gneissic metagabbro sample (ALV 620-3C), measured ${ }^{4} \mathrm{He}$ contents are $0.4-5$ orders of magnitude lower than those reported for basaltic glasses from the Mid-Cayman Rise (Kurz and Jenkins, 1981) (Figure 4.10a). Helium isotope compositions of most Cayman rocks fall within a relatively narrow range of 7.02-8.32 $\mathrm{R}_{\mathrm{a}}$, and are consistent with ${ }^{3} \mathrm{He} /{ }^{4} \mathrm{He}$ ratios documented in basaltic glasses from the Mid-Cayman Rise and other ocean ridges (Kurz and Jenkins, 1981; Allègre et al., 1983; Hiyagon et al., 1992) (Figure 4.10a). Average ${ }^{3} \mathrm{He} /{ }^{4} \mathrm{He}$ ratios of 6.58 and 9.91 $R_{a}$ for samples ALV 624-3-3 and 624-6-2, respectively, fall just outside this range, but have larger uncertainties owing to the extremely low He abundances of the samples. 


\subsubsection{Zambales}

Similar to serpentinized peridotite samples from the Mid-Cayman Rise, samples from the Zambales ophiolite have very low He abundances, with ${ }^{4} \mathrm{He}$ contents of $9.1 \times 10^{-11}$ to $1.3 \times 10^{-9}$ $\mathrm{cm}^{3} \mathrm{STP} / \mathrm{g}$ (Table 4.4). Average ${ }^{3} \mathrm{He} /{ }^{4} \mathrm{He}$ ratios range from 3.00 to $5.57 \mathrm{R}_{\mathrm{a}}$ and are lower than ${ }^{3} \mathrm{He} /{ }^{4} \mathrm{He}$ ratios in most Cayman samples, despite the large uncertainties in the measured values.

\section{DISCUSSION}

\subsection{Formation and compositional evolution of carbon-rich fluid inclusions in oceanic rocks}

Secondary fluid inclusions represent entrapped fluids along healed microfractures in a mineral. Fractures form during tectonic cooling of rocks below the brittle-ductile transition temperature of each mineral host $\left(\sim 700^{\circ} \mathrm{C}\right.$ in plagioclase, $775^{\circ} \mathrm{C}$ in olivine, and $580^{\circ} \mathrm{C}$ in pyroxene) (Kirby and Kronenberg, 1987; Buck, 1991; Manning et al., 2000). Carbon-bearing aqueous fluids circulating through the lower oceanic crust become trapped within minerals as microfractures heal. We propose that $\mathrm{CO}_{2}$ and $\mathrm{H}_{2} \mathrm{O}$ became trapped in plutonic and mantle rocks close to the ridge axis of the Mid-Cayman Rise. As rocks were exhumed along the detachment fault in the Mount Dent oceanic core complex and temperatures decreased to $<400^{\circ} \mathrm{C}, \mathrm{CO}_{2}$ and $\mathrm{H}_{2} \mathrm{O}$ reacted with their host minerals and underwent chemical re-equilibration. A decrease in temperature below $\sim 400^{\circ} \mathrm{C}$ increased the thermodynamic drive for $\mathrm{CO}_{2}$ reduction to $\mathrm{CH}_{4}$ (Shock, 1990), resulting in the formation of $\mathrm{CH}_{4}$-rich and $\mathrm{CO}_{2}$-poor secondary inclusions. Trapped volatiles were subsequently released farther from the ridge axis during alteration of the rocks by circulating hydrothermal fluids.

\subsubsection{Source of volatiles in secondary fluid inclusions}

The isotopic compositions of $\mathrm{CH}_{4}$ and helium in whole rock samples, as well as the high density of $\mathrm{CH}_{4}$ and lack of salts in fluid inclusions, may point to entrapment of phase-separated vapor-rich fluids enriched in magmatic $\mathrm{CO}_{2} \cdot{ }^{3} \mathrm{He} /{ }^{4} \mathrm{He}$ ratios of lower crustal plutonic and mantle rocks at Cayman all show MORB-like values (7-9 $\mathrm{R}_{\mathrm{a}}$ ) within analytical error (Figure 4.10), and are consistent with a mantle source for helium. Although ${ }^{4} \mathrm{He}$ abundances in Cayman samples are $\sim 1-5$ orders of magnitude lower than those in MORB from fast-spreading ocean ridges, these low values may reflect the magma-poor source region of the ultraslow-spreading Mid-Cayman Rise, and/or result from loss of $\mathrm{He}$ during alteration of the rock. $\delta^{13} \mathrm{C}_{\mathrm{CH}_{4}}$ values of -4.4 to $-7.9 \%$ 
measured in olivine gabbro and one troctolite sample from the Mid-Cayman Rise are indistinguishable from the isotopic composition of mantle-derived $\mathrm{CO}_{2}$ (Figure 4.11), and are consistent with a mantle source for carbon. Additional carbon may be sourced from deep infiltration of seawater-derived fluids into the lower crust. However, no chloride salts have been detected in any secondary inclusion, which would be present if a seawater-chlorinity fluid were trapped and became concentrated by the uptake of water during mineral hydration reactions (Sanford, 1981). Furthermore, the high density of $\mathrm{CH}_{4}$ trapped in individual fluid inclusions points to concentrations of carbon in circulating fluids that are much higher than those in seawater. If we assume that all $\mathrm{CH}_{4}$ gas now trapped in an inclusion was initially dissolved in an aqueous fluid, then we can use the $\mathrm{CH}_{4}$ vapor density determined by Raman spectroscopy to calculate a $\mathrm{CH}_{4(a q)}$ concentration. $\mathrm{CH}_{4}$ vapor densities of $0.16-0.24 \mathrm{~g} / \mathrm{cm}^{3}$ measured in olivinehosted secondary inclusions in sample ALV 624-3-3 correspond to $\mathrm{CH}_{4(a q)}$ concentrations of 10$15 \mathrm{~mol} / \mathrm{L}$. Assuming all $\mathrm{CH}_{4}$ was generated from reduction of $\Sigma \mathrm{CO}_{2}$, the concentration of $\Sigma \mathrm{CO}_{2}$ initially trapped in the fluid inclusions must have also been $10-15 \mathrm{~mol} / \mathrm{L}$. Not only are these $\Sigma \mathrm{CO}_{2}$ concentrations three orders of magnitude higher than those in bottom seawater, but they far exceed the solubility of $\mathrm{CO}_{2}$ in seawater-chlorinity solutions (Takenouchi and Kennedy, 1965; Duan and Sun, 2003). Alternatively, $\mathrm{CO}_{2}$ may be sourced from volatile-enriched, lowsalinity vapors produced by phase separation of seawater. Since olivine-hosted fluid inclusions must have formed above the lower temperature stability limit of olivine $\left(\sim 400^{\circ} \mathrm{C}\right)$, phase separation is likely to have occurred at supercritical conditions. However, supercritical phase separation of seawater cannot generate highly volatile-enriched vapors; volatile enrichment reaches a maximum of $\sim 2$ at near-critical conditions and decreases with increasing temperature (Seewald et al., 2003). Thus, $\Sigma \mathrm{CO}_{2}$ in seawater-derived fluids is unlikely to have supplied sufficient carbon for $\mathrm{CH}_{4}$ formation. This points to much higher quantities of $\mathrm{CO}_{2}$ in circulating fluids supplied by magmatic degassing in the subsurface.

\subsubsection{Compositional evolution of olivine-hosted secondary inclusions}

As olivine cooled to $<400^{\circ} \mathrm{C}$, it reacted with water trapped within secondary fluid inclusions and underwent closed-system serpentinization, as indicated by the presence of abundant $\mathrm{H}_{2}$, brucite, magnetite, and serpentine minerals (Table 4.2, Figure 4.6), according to the generalized reaction: 
Olivine $+\mathrm{H}_{2} \mathrm{O} \rightarrow$ Serpentine + Brucite + magnetite $+\mathrm{H}_{2}$

We propose that the accumulation of $\mathrm{H}_{2}$ generated by serpentinization drove the reduction of magmatic $\mathrm{CO}_{2}$ to $\mathrm{CH}_{4}$ and lesser quantities of $\mathrm{C}_{2+}$ alkanes via a Fisher-Tropsch-type reaction:

$\mathrm{CO}_{2}+\mathrm{H}_{2} \rightarrow \mathrm{CH}_{4}+\mathrm{C}_{2} \mathrm{H}_{6}+\ldots+\mathrm{H}_{2} \mathrm{O}$

The synthesis of low molecular-weight hydrocarbons was likely catalyzed by magnetite present in the inclusions (Fu et al., 2007). Lack of detectable $\mathrm{CO}_{2}$ in olivine-hosted inclusions suggests that $\mathrm{CO}_{2}$ reduction to hydrocarbons went to completion or near completion. However, the precipitation of carbonate minerals observed in some samples may have limited hydrocarbon production by consuming $\mathrm{CO}_{2}$. Uptake of $\mathrm{Fe}^{2+}$ into the $\mathrm{FeCO}_{3}$ component of carbonate minerals may have also decreased the amount of $\mathrm{H}_{2}$ generated from serpentinization (Jones et al., 2010), thereby further reducing the thermodynamic drive for hydrocarbon production. The occurrence of Ca-bearing carbonates in olivine-hosted fluid inclusions suggests that circulating fluids contained dissolved $\mathrm{Ca}$ that was likely acquired from fluid-rock reactions in surrounding Ca-rich minerals, including plagioclase and pyroxene.

\subsubsection{Compositional evolution of plagioclase- and clinopyroxene-hosted secondary inclusions}

Unlike olivine-hosted inclusions, plagioclase-hosted inclusions have no internal mechanism for generating $\mathrm{H}_{2}$. However, the presence of $\mathrm{H}_{2}$ in plagioclase-hosted inclusions in some Cayman samples suggests that $\mathrm{CH}_{4}$ was formed from the reduction of $\mathrm{CO}_{2}$ by externallyderived $\mathrm{H}_{2}$ according to reaction $2 . \mathrm{H}_{2}$ may be derived from a number of external sources, including early degassing of melts, radiolytic reactions, and serpentinization of surrounding olivine-rich rocks.

While no $\mathrm{H}_{2}$ was detected in any clinopyroxene-hosted secondary inclusion, $\mathrm{H}_{2}$ may be below the detection limit of Raman spectroscopy, or may have been completely consumed by reduction of $\mathrm{CO}_{2} . \mathrm{H}_{2}$, if present, may be derived from an external source as in plagioclase. Some $\mathrm{H}_{2}$ may additionally be generated by oxidation of $\mathrm{Fe}^{2+}$ in clinopyroxene to $\mathrm{Fe}^{3+}$ in tremoliteactinolite. $\mathrm{CH}_{4}$ present in clinopyroxene-hosted inclusions may have, therefore, formed from 
reduction of $\mathrm{CO}_{2}$ according to reaction 2. Alternatively, $\mathrm{CH}_{4}$ occurring in both plagioclase- and clinopyroxene-hosted inclusions may have been externally-derived.

\subsubsection{Carbon isotopic evolution of hydrocarbons}

The carbon isotopic composition of hydrocarbons in fluid inclusions is controlled by a number of factors, including temperature, isotopic composition of the $\mathrm{CO}_{2}$ source, and partitioning of carbon among different species (e.g., $\mathrm{CO}_{2}, \mathrm{CH}_{4}, \mathrm{C}_{2+}$ alkanes, and carbonate minerals). Fisher-Tropsch-type synthesis of organic compounds under hydrothermal conditions generates $\mathrm{CH}_{4}$ and $\mathrm{C}_{2+}$ alkanes that are significantly depleted in ${ }^{13} \mathrm{C}$ relative to the initial $\mathrm{CO}_{2}$ source (Horita and Berndt, 1999; McCollom and Seewald, 2006). For instance, equilibrium ${ }^{13} \mathrm{C} /{ }^{12} \mathrm{C}$ fractionation factors between dissolved $\mathrm{CO}_{2}$ and $\mathrm{CH}_{4}$ have been calculated as $1000 \ln (\alpha)$ $=-30$ and -18 at $200^{\circ} \mathrm{C}$ and $300^{\circ} \mathrm{C}$, respectively (Horita and Berndt, 1999). Generation of $\mathrm{CH}_{4}$ with mantle $\delta^{13} \mathrm{C}$ values (-4 to $-10 \%$ ) from magmatic $\mathrm{CO}_{2}$ would, therefore, require the quantitative reduction of $\mathrm{CO}_{2}$ to $\mathrm{CH}_{4}$ in a closed system. Removal of some $\mathrm{CO}_{2}$ by carbonate precipitation would moderately enrich or deplete the remaining $\mathrm{CO}_{2}$ in ${ }^{13} \mathrm{C}$ at $>200^{\circ} \mathrm{C}$, depending on the temperature and type of carbonate mineral formed (Chacko et al., 2001). Equilibrium carbon isotope fractionation factors between $\mathrm{CO}_{2}$ and carbonate minerals vary between $1000 \ln (\alpha)=-5$ and +5 at temperatures $>200^{\circ} \mathrm{C}$ (Chacko et al., 2001). Carbonate precipitation would be expected to occur prior to $\mathrm{CH}_{4}$ formation due to the slow kinetics associated with Fisher-Tropsch-type reactions under hydrothermal conditions (Chapters 2-3; McCollom and Seewald, 2001; McCollom and Seewald, 2007). This would decrease the amount of $\mathrm{CO}_{2}$ available for hydrocarbon production, so that less $\mathrm{CO}_{2}$ needs to be reduced to form $\mathrm{CH}_{4}$ with magmatic ${ }^{13} \mathrm{C}$ values. $\mathrm{CH}_{4}$ with a carbon isotopic composition that is significantly lighter than $10 \%$ indicates incomplete reduction of magmatic $\mathrm{CO}_{2}$ to $\mathrm{CH}_{4}$ at high temperatures $\left(>200^{\circ} \mathrm{C}\right)$, with or without attendant carbonate precipitation. At temperatures lower than $200^{\circ} \mathrm{C}$, carbonate

minerals become more enriched in ${ }^{13} \mathrm{C}$, particularly $\mathrm{Mg}$ - and Fe-bearing carbonates (Chacko et al., 2001). Thus, carbonate precipitation at $<200^{\circ} \mathrm{C}$ would be expected to deplete co-existing $\mathrm{CO}_{2}$ in ${ }^{13} \mathrm{C}$, and result in the production of isotopically lighter $\mathrm{CH}_{4}$. Carbon isotopic compositions of hydrocarbons and carbonate minerals in secondary inclusions are, therefore, strongly influenced by the cooling path of the host rock. 


\subsection{Comparison of results to previous fluid inclusion studies}

Seminal studies have been conducted on $\mathrm{CH}_{4}$-rich fluid inclusions in gabbroic rocks from the ultraslow-spreading Southwest Indian Ridge (SWIR) and Mid-Cayman Rise (Kelley, 1996; Kelley and Früh-Green, 1999; Kelley and Früh-Green, 2001). Carbon isotopic compositions of $\mathrm{CH}_{4}$ in most SWIR samples range from $-18.0 \%$ o to $-34.2 \%$ (Kelley and Früh-Green, 1999; Kelley and Früh-Green, 2001), with only two samples exhibiting higher $\delta^{13} \mathrm{C}$ values of -9.1\%o and -11.5\%o (Kelley and Früh-Green, 1999). With the exception of the two isotopically heaviest values, $\delta^{13} \mathrm{C}_{\mathrm{CH}_{4}}$ values in SWIR gabbros are significantly lower than those measured in plutonic rocks in this study (-4.4\%o to $-16.7 \%$ ) (Figure 4.11). Isotopic analyses of $\mathrm{CH}_{4}$ in SWIR gabbros were performed by step-heating of the samples to $>900-1000^{\circ} \mathrm{C}$ to decrepitate fluid inclusions and release trapped gases (Kelley and Früh-Green, 1999; Kelley and Früh-Green, 2001). Heating at these temperatures can also generate $\mathrm{CH}_{4}$ by pyrolysis of organic carbon material, which make up a variable but significant portion ( 2 to $>90 \%$ ) of the total carbon content of altered oceanic rocks, including basalt, gabbro, and serpentinized peridotite (Delacour et al., 2008; Shilobreeva et al., 2011; Schwarzenbach et al., 2013). Reduced carbon phases in oceanic rocks consist of long-chain hydrocarbons $\left(\mathrm{C}_{14+}\right)$ with bulk $\delta^{13} \mathrm{C}$ values ranging from $-22 \%$ to $-29 \%$ (Delacour et al., 2008; Schwarzenbach et al., 2013). Thus, it is possible that heating of altered oceanic rocks during analysis may generate isotopically depleted $\mathrm{CH}_{4}$ from pyrolysis of higher weight organic compounds, which may account for the lower $\delta^{13} \mathrm{C}_{\mathrm{CH}_{4}}$ values of SWIR gabbros that do not accurately reflect the isotopic composition of $\mathrm{CH}_{4}$ trapped in fluid inclusions.

Kelley and Früh-Green (2001) also analyzed bulk carbon isotope ratios and carbon contents of gabbros from the Mid-Cayman rise using elemental analysis combined with isotope ratio mass spectroscopy (EA/IRMS), following extraction by step-heating to $1060^{\circ} \mathrm{C}$. They obtained more depleted whole rock $\delta^{13} \mathrm{C}$ values (-23.6\%o to $-26.7 \%$ ) and significantly higher carbon contents $(\sim 2,000-11,000 \mathrm{nmol} / \mathrm{g})$ than those obtained by crushing of olivine gabbros in this study. The difference in carbon abundances and isotope ratios may reflect several factors, including sample variability and differences in methodology. Unlike mechanical crushing, the step-heating method employed by Kelley and Früh-Green (2001) decrepitates all fluid inclusions in a sample, which should yield higher $\mathrm{CH}_{4}$ contents. Indeed, back-scattered electron (BSE) images of crushed samples in the present study reveal a significant portion of mineral grains with diameters greater than $1 \mu \mathrm{m}$, indicating incomplete crushing. However, it appears unlikely that 
the amount of hydrocarbons remaining in the uncrushed portion can account for the significantly higher carbon contents measured by Kelley and Früh-Green (2001), which are $\geq 1$ order of magnitude higher than those analyzed in the present study.

As noted by Kelley and Früh-Green (2001), elemental analysis cannot distinguish between different carbon species, such as $\mathrm{CH}_{4}, \mathrm{CO}_{2}$, and higher weight hydrocarbons. Isotope ratio measurements demonstrate that fluid inclusions in Cayman olivine gabbros are dominated by $\mathrm{CH}_{4}$, with only minor amounts of $\mathrm{C}_{2} \mathrm{H}_{6}$ and potentially other low-molecular weight hydrocarbons. $\mathrm{CO}_{2}$ was not detected in any sample by Raman spectroscopy, and was below blank levels in the isotope ratio measurements. Thus, it appears that the amounts of gases other than $\mathrm{CH}_{4}$ in fluid inclusions are present at insufficient levels to account for the difference between hydrocarbon abundances in the present study and bulk carbon abundances in Kelley and Früh-Green (2001). This suggests that the high carbon contents obtained by elemental analysis in Kelley and Früh-Green (2001) may reflect carbon sources other than fluid inclusions, including carbonate minerals and reduced carbon compounds disseminated in the mineral matrix or lining mineral grain boundaries. These carbon compounds likely have a distinct isotopic composition from $\mathrm{CH}_{4}$ hosted in fluid inclusions, which may explain the lower whole rock $\delta^{13} \mathrm{C}$ values determined by Kelley and Früh-Green (2001) relative to $\mathrm{CH}_{4}$ determined in this study. Indeed, studies of basaltic glass and mantle xenoliths demonstrate the occurrence of condensed carbonaceous material as films and discrete particles along crack surfaces, grain boundaries, and fluid inclusion walls (Mathez and Delaney, 1981; Mathez, 1987; Pineau and Mathez, 1990; Tingle et al., 1990; Tingle et al., 1991; Sugisaki and Mimura, 1994). This carbonaceous material consists of complex mixtures of amorphous carbon material, graphite, and organic compounds, including aliphatic and aromatic hydrocarbons (Mathez and Delaney, 1981; Mathez, 1987; Pineau and Mathez, 1990; Tingle et al., 1990; Tingle et al., 1991; Sugisaki and Mimura, 1994), with bulk carbon isotopic compositions of $-22 \%$ to $-29 \%$ (Pineau and Mathez, 1990; Sugisaki and Mimura, 1994; Deines, 2002). Gabbroic and ultramafic rocks in altered oceanic crust contain variable but significant quantities of organic carbon, up to $7000 \mathrm{ppm}$, with a similar range in $\delta^{13} \mathrm{C}$ compositions (-22\%o to -29\%) (Delacour et al., 2008; Schwarzenbach et al., 2013). Pyrolysis of this reduced carbon material is expected to generate carbon isotopic values that are more ${ }^{13} \mathrm{C}$-depleted than those measured in the present study. Carbonate minerals are also a ubiquitous carbon phase in lower crustal plutonic and mantle rocks in the oceanic lithosphere 
(Bach et al., 2001; Eickmann et al., 2009; Bach et al., 2011; Alt et al., 2013; Schwarzenbach et al., 2013; Klein et al., 2015; Schroeder et al., 2015). However, carbonates are significantly more ${ }^{13} \mathrm{C}$-enriched relative to reduced carbon species. $\delta^{13} \mathrm{C}$ values are typically close to $0 \%$ for carbonates formed from seawater-derived inorganic carbon, but can be as low as $-6 \%$ for a mantle-derived carbon source (Eickmann et al., 2009; Bach et al., 2011; Schroeder et al., 2015). Thus, decomposition of carbonate minerals is expected to produce more ${ }^{13} \mathrm{C}$-enriched isotopic values relative to those measured in this study, and cannot explain the lower whole rock $\delta^{13} \mathrm{C}$ values of Kelley and Früh-Green (2001).

\subsection{Comparison of results to Von Damm hydrothermal fluids}

The Von Damm hydrothermal field situated on the Mid-Cayman spreading center emits intermediate-temperature fluids, up to $226^{\circ} \mathrm{C}$, that are $\mathrm{H}_{2(\mathrm{aq})}$ - and hydrocarbon-rich, metal-poor, and near pH-neutral (McDermott et al., 2015). The highest temperature fluids are particularly enriched in dissolved $\mathrm{H}_{2}(18.2 \mathrm{mmol} / \mathrm{kg}), \mathrm{CH}_{4}(2.81 \mathrm{mmol} / \mathrm{kg})$, and $\mathrm{C}_{2} \mathrm{H}_{6}(639 \mathrm{nmol} / \mathrm{kg})$, and have a $\mathrm{CH}_{4} / \mathrm{C}_{2} \mathrm{H}_{6}$ ratio of 4397 (McDermott et al., 2015). Average $\delta^{13} \mathrm{C}$ compositions of $\mathrm{CH}_{4(a q)}$ and $\mathrm{C}_{2} \mathrm{H}_{6(a q)}$ in Von Damm vent fluids are - $15.4 \%$ and $-12.7 \%$, respectively (McDermott et al., 2015). ${ }^{3} \mathrm{He} /{ }^{4} \mathrm{He}$ ratios of $8.14 \pm 0.13 \mathrm{R}_{\mathrm{a}}$ fall within the range of values measured in MORB glasses, and are consistent with a mantle source for helium at Von Damm (Kurz and Jenkins, 1981; Allègre et al., 1983; Hiyagon et al., 1992; McDermott et al., 2015).

$\delta^{13} \mathrm{C}_{\mathrm{CH}_{4}}$ values measured in mafic and ultramafic rocks from Cayman (-4.4\%o to $-16.7 \%$ ) appear to be consistent with the carbon isotopic composition of $\mathrm{CH}_{4(a q)}$ in Von Damm hydrothermal fluids (-15.4\%) (Figure 4.11). In addition, the $\delta^{13} \mathrm{C}$ compositions of $\mathrm{C}_{2} \mathrm{H}_{6}$ extracted from most Cayman samples (-10.6\% to -20.3\%o), with the exception of ALV 620-5-1, are similar to $\delta^{13} \mathrm{C}_{\mathrm{C}_{2} \mathrm{H}_{6}}$ values in Von Damm fluids (-12.7\%) (Figure 4.12). In contrast, $\mathrm{C}_{2} \mathrm{H}_{6}$ in the olivine gabbro sample, ALV $620-5-1$, is extremely ${ }^{13} \mathrm{C}$-enriched $\left(\delta^{13} \mathrm{C}=+0.7 \%\right.$ o) relative to $\mathrm{C}_{2} \mathrm{H}_{6}$ at Von Damm. While this may suggest that olivine gabbro is compositionally distinct from other rock types, only one robust ethane measurement was obtained for olivine gabbro. Measured ${ }^{3} \mathrm{He} /{ }^{4} \mathrm{He}$ ratios in Cayman rocks all show MORB-like values within analytical error (Table 4.4, Figure 4.10), and are also consistent with the average ${ }^{3} \mathrm{He} /{ }^{4} \mathrm{He}$ ratio $\left(8.14 \pm 0.13 \mathrm{R}_{\mathrm{a}}\right)$ in Von Damm vent fluids (McDermott et al., 2015). The similarity in isotopic compositions between Von Damm fluids and Cayman rocks suggests that hydrocarbon and helium budgets at Von Damm may be 
influenced by interaction of seawater-derived hydrothermal fluids with olivine-rich rocks in the subsurface. While Von Damm hydrothermal fluids may be influenced by more than one type of olivine-rich lithology, including peridotite, troctolite, and gabbroic rocks, more samples would need to be analyzed to better characterize the range in carbon and helium isotopic compositions for a given lithology.

$\mathrm{CH}_{4} / \mathrm{C}_{2} \mathrm{H}_{6}$ ratios of 315-1372 in Cayman rocks are more than three times lower than ratios in Von Damm endmember fluids (4397) (McDermott et al., 2015) (Figure 4.13). Higher $\mathrm{CH}_{4} / \mathrm{C}_{2} \mathrm{H}_{6}$ ratios at Von Damm may reflect several factors, including differential release of hydrocarbons from the source rock or differential oxidation during subsurface fluid flow. Laboratory experiments of $\mathrm{n}$-alkane oxidation under hydrothermal conditions demonstrate enhanced decomposition rates of $\mathrm{C}_{2}$ hydrocarbons relative to $\mathrm{CH}_{4}$ in the presence of Fe-bearing minerals (Seewald, 2001). Experimentally-determined half-lives of $\mathrm{C}_{2} \mathrm{H}_{6}$ by oxidative decomposition at $300-350^{\circ} \mathrm{C}$ are on the order of a few months (Seewald, 2001), and are shorter than residence times of $<3-10$ years estimated for actively convecting fluids in submarine hydrothermal systems (Kadko and Moore, 1988; Kadko and Butterfield, 1998). Thus, degradation of $\mathrm{C}_{2} \mathrm{H}_{6}$ during subsurface fluid flow may contribute to higher dissolved $\mathrm{CH}_{4} / \mathrm{C}_{2} \mathrm{H}_{6}$ ratios at the Von Damm hydrothermal field.

Measured $\mathrm{CH}_{4} /{ }^{3} \mathrm{He}$ ratios in Von Damm vent fluids $\left(2.4 \times 10^{8}\right)$ are just below the average $\Sigma \mathrm{CO}_{2} /{ }^{3} \mathrm{He}$ ratio in N-MORB $\left(\sim 1 \times 10^{9}\right)$ (Marty and Tolstikhin, 1998), indicating that a substantial portion of $\mathrm{CH}_{4}$ at Von Damm ( 24\%) is derived from mantle $\mathrm{CO}_{2}$ (McDermott et al., 2015). However, rocks from the Mid-Cayman Rise, with the exception of sample ALV 620-3C, all exhibit $\mathrm{CH}_{4}{ }^{3} \mathrm{He}$ ratios significantly higher than $1 \times 10^{9}$, indicating either the addition of carbon or loss of helium (Figure 4.10b). Several factors may account for these high values, in particular, the different methodologies used to analyze hydrocarbon and helium contents. Hydrocarbon abundances were measured by crushing whole rock samples 800 times each, whereas helium contents were measured by crushing whole-rock samples only 20 times each, possibly resulting in the extraction of fewer volatiles per unit mass of rock. In addition, vacuum crushing and melting experiments demonstrate that the majority (79-95\%) of helium in oceanic peridotites and mylonites is contained within mineral matrices as opposed to fluid and melt inclusions (Kurz et al., 2009). Thus, vacuum crushing of Cayman peridotites may have released only a small fraction of $\mathrm{He}$ from the rocks, which may explain the high $\mathrm{CH}_{4} /{ }^{3} \mathrm{He}$ ratios obtained for these samples. If 
helium and $\mathrm{CH}_{4}$ primarily reside in distinct domains of a rock or mineral, then they may also be released in different proportions during alteration and fracturing of the rock host associated with subsurface fluid flow. This may account for the discrepancy in $\mathrm{CH}_{4} /{ }^{3} \mathrm{He}$ ratios measured in Cayman rocks and Von Damm vent fluids.

Whole-rock hydrocarbon abundances in Cayman samples were used to estimate waterrock $(\mathrm{W} / \mathrm{R})$ mass ratios needed to account for the concentrations of dissolved $\mathrm{CH}_{4}(2.81$ $\mathrm{mmol} / \mathrm{kg})$ and $\mathrm{C}_{2} \mathrm{H}_{6}(639 \mathrm{nmol} / \mathrm{kg})$ in endmember fluids at the Von Damm hydrothermal field (McDermott et al., 2015). W/R mass ratios were calculated assuming measured $\mathrm{CH}_{4}$ and $\mathrm{C}_{2} \mathrm{H}_{6}$ abundances in Cayman samples represent the maximum amount of hydrocarbons that can be extracted from the rocks. Hydrocarbons were also assumed to be quantitatively leached during hydrothermal alteration and to not undergo secondary reactions. $\mathrm{CH}_{4}$ abundances in Cayman samples yield W/R mass ratios of 0.002 to 0.11 (Table 4.5). Although W/R mass ratios estimated for seafloor hydrothermal systems are typically higher than these calculated values, ratios as low as 0.1-0.5 have been estimated for some seafloor vent sites (Von Damm et al., 1985; Spivack and Edmond, 1987; Mottl et al., 2011; Reeves et al., 2011). W/R mass ratios calculated from $\mathrm{C}_{2} \mathrm{H}_{6}$ contents in Cayman rocks, in contrast, are an order of magnitude higher (0.02-1.6) than those calculated from $\mathrm{CH}_{4}$ contents, and appear more consistent with W/R mass ratios estimated for natural systems. Note that calculated W/R mass ratios represent minimum values as crushing cannot release all hydrocarbons from a rock. In addition, alteration and fracturing of rock during subsurface fluid flow and exhumation may have already extracted a significant portion of hydrocarbons from the samples. Peridotite samples, in particular, are $>80-90 \%$ altered according to visual estimates in thin section, suggesting that only a small fraction of secondary fluid inclusions have remained intact since their formation. Furthermore, W/R mass ratios estimated from trace elements in natural systems always represent maximum values due to incomplete leaching of chemically-bound elements.

\subsection{Comparison of results to Zambales gas seeps}

Gases issuing at ambient temperature from fractures in partially serpentinized ultramafic rock in the Zambales ophiolite are extremely rich in $\mathrm{H}_{2}$ (up to 46 vol.\%) and $\mathrm{CH}_{4}$ (up to 55 vol.\%) (Abrajano et al., 1988). Reduced gases also contain elevated amounts of He (up to 6.9 ppm), $\mathrm{C}_{2} \mathrm{H}_{6}$ (up to 0.15 vol.\%), and other $\mathrm{C}_{2+}$ hydrocarbons, and exhibit $\mathrm{CH}_{4} / \mathrm{C}_{2} \mathrm{H}_{6}$ ratios of 325 - 
457 (Abrajano et al., 1988). $\mathrm{CH}_{4}$ gas emanating from the Zambales ophiolite has an average $\delta^{13} \mathrm{C}$ value of $-7.0 \pm 0.4 \%$ (Abrajano et al., 1988). Measured ${ }^{3} \mathrm{He} /{ }^{4} \mathrm{He}$ ratios of $4.03 \pm 0.05 \mathrm{R}_{\mathrm{a}}$ are below the range typically attributable to a mantle origin $\left(7-9 R_{a}\right)$ and are thought to reflect the addition of radiogenic ${ }^{4} \mathrm{He}$ from the decay of $\mathrm{U}$ and $\mathrm{Th}$ in the ultramafic protolith (Abrajano et al., 1988). Serpentinization temperatures estimated for the Zambales ophiolite range from $30^{\circ} \mathrm{C}$ to $350^{\circ} \mathrm{C}$ (Abrajano, 1984; Sturchio et al., 1989). In addition, constraints from $\mathrm{H}_{2}-\mathrm{H}_{2} \mathrm{O}$ and $\mathrm{H}_{2}$ $\mathrm{CH}_{4} \delta \mathrm{D}$ isotope fractionations in gas seeps indicate equilibration temperatures of $110-157^{\circ} \mathrm{C}$ (Abrajano et al., 1988; Abrajano et al., 1990), further supporting a low-temperature origin for Zambales gases.

$\mathrm{CH}_{4} / \mathrm{C}_{2} \mathrm{H}_{6}$ ratios of 163-431 in serpentinized dunite and peridotite from Zambales are similar to measured ratios in Zambales gas seeps (325-457) (Abrajano et al., 1988) (Figure 4.13). In addition, the average $\delta^{13} \mathrm{C}$ composition of $\mathrm{CH}_{4(g)}$ in gas seeps $(-7.0 \pm 0.4 \%$ ) falls within the range of $\delta^{13} \mathrm{C}_{\mathrm{CH}_{4}}$ measured in serpentinized dunite and peridotite from the region (-2.8 to 12.4\%o), suggesting that $\mathrm{CH}_{4}$ in Zambales gas seeps may represent a mixed source (Figure 4.11). To our knowledge, no isotopic analyses have been made of $\mathrm{C}_{2} \mathrm{H}_{6}$ gas from the Zambales ophiolite. Overall, $\mathrm{CH}_{4}$ and $\mathrm{C}_{2} \mathrm{H}_{6}$ extracted from a mixture of serpentinized dunite and peridotite are consistent with the chemical and isotopic composition of reduced gases issuing from the ophiolite. This suggests that fluid inclusions in ultramafic rock may provide a significant source of hydrocarbons to aqueous fluids in the Zambales ophiolite as they alter and fracture the surrounding host rock. Average ${ }^{3} \mathrm{He} /{ }^{4} \mathrm{He}$ ratios of 3.0 to $5.6 \mathrm{R}_{\mathrm{a}}$ in serpentinized dunite and peridotite (Table 4.4) are consistent with measured ${ }^{3} \mathrm{He} /{ }^{4} \mathrm{He}$ ratios of $4.03 \pm 0.05 \mathrm{R}_{\mathrm{a}}$ in Zambales gas seeps (Abrajano et al., 1988). In addition, the average $\mathrm{CH}_{4} /{ }^{3} \mathrm{He}$ ratio in Zambales gas seeps $\left(1.6 \times 10^{10} \pm 0.2 \times 10^{10}\right.$ ) (Abrajano et al., 1988) lies between measured $\mathrm{CH}_{4}{ }^{3} \mathrm{He}$ ratios in serpentinized samples, which lends further support for fluid inclusions as a potential contributor to gas contents in the Zambales ophiolite.

\subsection{Implications for the origin of abiotic hydrocarbons in serpentinization systems}

Unsedimented, ultramafic-influenced hydrothermal sites on the seafloor show remarkably similar compositions of dissolved hydrocarbons in venting fluids, in spite of their widely different subsurface temperatures, circulation histories, and inorganic fluid chemistries. For example, endmember fluids at Rainbow are among the most acidic and metal-rich observed in 
mid-ocean ridge (MOR) hydrothermal systems, and have reached temperatures of $>370^{\circ} \mathrm{C}$ (Charlou et al., 2002; Seyfried et al., 2011). In contrast, fluids venting from the Lost City hydrothermal field are strongly alkaline and metal-poor, and have likely experienced maximum temperatures of only $110-250^{\circ} \mathrm{C}$ (Kelley et al., 2001; Allen and Seyfried, 2004; Kelley et al., 2005; Proskurowski et al., 2006; Foustoukos et al., 2008; Seyfried et al., 2015). Yet, the abundances and isotopic compositions of dissolved $\mathrm{CH}_{4}$ and $\mathrm{C}_{2+}$ hydrocarbons are remarkably similar in these diverse vent sites. Among all ultramafic-influenced mid-ocean ridge systems, dissolved $\mathrm{CH}_{4}$ exhibits a relatively narrow range in concentration from $0.5 \mathrm{mM}$ to $3.5 \mathrm{mM}$, while dissolved $\mathrm{C}_{2} \mathrm{H}_{6}$ exhibits concentrations of $0.1-5.7 \mu \mathrm{M}$, with the majority of values falling between $0.6 \mu \mathrm{M}$ and $1 \mu \mathrm{M}$ (Charlou et al., 2002; Kelley et al., 2005; Schmidt et al., 2007; Proskurowski et al., 2008; Charlou et al., 2010; McDermott et al., 2015). $\delta^{13} \mathrm{C}$ values vary from 6.1\%o to $-17.8 \%$ in $\mathrm{CH}_{4}$, and from $-2.0 \%$ o to $-15.2 \%$ in $\mathrm{C}_{2} \mathrm{H}_{6}$ (Charlou et al., 2002; Kelley et al., 2005; Proskurowski et al., 2008; Charlou et al., 2010; McDermott et al., 2015). In addition, recent analyses of clumped methane isotopologues reveal similar apparent equilibrium temperatures of $310_{-42}^{+53}{ }^{\circ} \mathrm{C}$ for a variety of ultramafic- and basalt-influenced seafloor hydrothermal systems (Wang et al., 2017). The similarity in hydrocarbon composition among chemically-distinct vent sites suggests that hydrocarbons may be generated by a common process that is separate from active fluid circulation in the subsurface.

Comparison of $\mathrm{CH}_{4}$ and $\mathrm{C}_{2} \mathrm{H}_{6}$ isotopic compositions in olivine-rich rocks at the MidCayman Rise with fluids venting at the Von Damm hydrothermal field suggests that a significant portion of abiotic hydrocarbons may be derived from the leaching of carbon-rich fluid inclusions at this site. There is also considerable overlap among $\delta^{13} \mathrm{C}_{\mathrm{CH}_{4}}$ and $\delta^{13} \mathrm{C}_{\mathrm{C}_{2} \mathrm{H}_{6}}$ values from Cayman rocks and from fluids venting at both ultramafic- and basalt-influenced mid-ocean ridge systems (Figures 4.11 and 4.12). For instance, $\mathrm{CH}_{4}$ isotopic compositions in Cayman samples span nearly the entire range of $\delta^{13} \mathrm{C}_{\mathrm{CH}_{4}}$ values from ultramafic-influenced vent fluids, and further coincide with the more ${ }^{13} \mathrm{C}$-enriched portion of $\delta^{13} \mathrm{C}_{\mathrm{CH}_{4}}$ values from basalt-influenced vent fluids (Figure 4.11). The observed similarity in $\mathrm{CH}_{4}$ and $\mathrm{C}_{2} \mathrm{H}_{6}$ isotopic compositions suggests that leaching of fluid inclusions in olivine-rich rocks may contribute hydrocarbons to seafloor vent fluids hosted in a variety of geologic settings, and not just sites with known exposures of mantle rock. Since approximately half of all high-temperature hydrothermal systems on slow-spreading ridges are hosted in tectonically-controlled settings, where lower-crustal plutonic and mantle rocks are 
uplifted to shallow levels (German et al., 2016), this suggests that a substantial portion of basalthosted systems may interact with olivine-rich rocks in the subsurface.

Although $\mathrm{CH}_{4} / \mathrm{C}_{2} \mathrm{H}_{6}$ ratios of 315-1372 in Cayman rocks are more than three times lower than values in Von Damm endmember fluids (4397) (McDermott et al., 2015), they are similar to $\mathrm{CH}_{4} / \mathrm{C}_{2} \mathrm{H}_{6}$ ratios of 957-1269 measured in fluids venting from the Lost City hydrothermal field (Proskurowski et al., 2008). Relatively low reaction zone temperatures of $110-250^{\circ} \mathrm{C}$ are estimated for Lost City (Allen and Seyfried, 2004; Kelley et al., 2005; Proskurowski et al., 2006; Foustoukos et al., 2008), which may kinetically inhibit oxidative decomposition of $\mathrm{C}_{2+}$ alkanes once they are extracted from host rocks in the subsurface. The low temperatures of gas seeps in the Zambales ophiolite may similarly inhibit oxidation of ethane gas and preserve $\mathrm{CH}_{4} / \mathrm{C}_{2} \mathrm{H}_{6}$ ratios from the host rocks. Thus, it appears that the lower temperatures of circulating fluids at both Lost City and the Zambales ophiolite may preserve original $\mathrm{CH}_{4} / \mathrm{C}_{2} \mathrm{H}_{6}$ ratios sourced from fluid inclusions.

While it is possible that $\mathrm{CH}_{4}$ may be formed from dissolved $\mathrm{CO}_{2}$ during active convection of seawater-derived fluids in the crust, strong kinetic barriers to $\mathrm{CH}_{4}$ production on the timescale of hydrothermal circulation argue against such a model (Chapters 2-3; McCollom and Seewald, 2001; McCollom and Seewald, 2003; Seewald et al., 2006; McCollom et al., 2016). Crustal residence times of $<3-10$ years have been estimated for high-temperature $\left(>200^{\circ} \mathrm{C}\right)$ fluids in mid-ocean ridge hydrothermal systems (Kadko and Moore, 1988; Kadko and Butterfield, 1998), suggesting there is insufficient time for significant quantities of $\mathrm{CH}_{4}$ to form during active fluid convection. Longer reaction times can be achieved by trapping magmatic volatiles within fluid inclusions in lower crustal plutonic and mantle rocks. Constraints from thermochronology indicate that rocks exhumed along oceanic detachment faults take 0.3-0.7 Ma to cool from $\sim 850^{\circ} \mathrm{C}$ to $200^{\circ} \mathrm{C}$ (John et al., 2004; Grimes et al., 2008; Baines et al., 2009; Schwartz et al., 2009; Grimes et al., 2011). This suggests that carbon-rich fluid inclusions may persist in the subsurface for up to hundreds of thousands of years before extraction by circulating seawater-derived fluids, which may allow sufficient time for the reduction of dissolved $\mathrm{CO}_{2}$ to $\mathrm{CH}_{4}$ and other low-molecular weight hydrocarbons.

Abiotic $\mathrm{CH}_{4}$ and other hydrocarbons have been documented in several low-temperature $\left(<150^{\circ} \mathrm{C}\right)$ serpentinization systems on land, including the Zambales ophiolite in the Philippines (Abrajano et al., 1988), Semail ophiolite in Oman (Sano et al., 1993; Miller et al., 2016), and 
Tekirova ophiolite in Turkey (Hosgormez et al., 2008; Etiope et al., 2011). $\mathrm{H}_{2}$ produced by present-day serpentinization of ultramafic rocks has been generally assumed to react with dissolved $\Sigma \mathrm{CO}_{2}$ in meteoric fluids and generate $\mathrm{CH}_{4}$ and other hydrocarbons through FischerTropsch-type reactions (Abrajano et al., 1988; Sano et al., 1993; Hosgormez et al., 2008; Etiope et al., 2011; Boschetti et al., 2013; Etiope et al., 2013; Miller et al., 2016). However, aqueous reduction of $\Sigma \mathrm{CO}_{2}$ to $\mathrm{CH}_{4}$ is expected to be kinetically inhibited at the low temperatures of these serpentinization systems (e.g., Chapter 3; Seewald et al., 2006; McCollom, 2016). Results from this study suggest that $\mathrm{CH}_{4}$ and $\mathrm{C}_{2} \mathrm{H}_{6}$ issuing from seeps in the Zambales ophiolite may, instead, be sourced form fluid inclusions in the ultramafic protolith. Hydrocarbons trapped in mineralhosted fluid inclusions may be extracted during hydrothermal alteration or fracturing of the rock, and released into meteoric fluids as they circulate in the subsurface. Fluid inclusions may similarly contribute hydrocarbons to other continental serpentinization systems, suggesting that active $\mathrm{CO}_{2}$ reduction may not be occurring.

\section{CONCLUSIONS}

Lower crustal plutonic and mantle rocks at the Mid-Cayman Rise and the Zambales ophiolite contain appreciable quantities of $\mathrm{CH}_{4}$ and $\mathrm{C}_{2} \mathrm{H}_{6}$ hosted in secondary fluid inclusions. Whole rock $\mathrm{CH}_{4}$ and $\mathrm{C}_{2} \mathrm{H}_{6}$ isotopic compositions at the Mid-Cayman Rise are similar to the range in carbon isotopic compositions in fluids venting not only at Von Damm, but at other ultramafic-influenced hydrothermal sites on the seafloor. These findings suggest that leaching of fluid inclusions, by alteration or fracturing of the rock during subsurface fluid flow, may provide a significant contribution of hydrocarbons to hydrothermal fluids at Von Damm and potentially other ultramafic-influenced vent sites. A model for hydrocarbon formation in fluid inclusions appears to reconcile inconsistencies between the current paradigm for $\mathrm{CH}_{4}$ formation during active fluid circulation and field data suggesting that $\mathrm{CH}_{4}$ is not sourced from $\Sigma \mathrm{CO}_{2}$ in convecting fluids. While circulating seawater-derived fluids transport dissolved hydrocarbons to the seafloor, current evidence does not support their direct involvement in hydrocarbon production. Instead, $\mathrm{CH}_{4}$ and $\mathrm{C}_{2+}$ alkanes appear to be formed in $\mathrm{H}_{2}$-rich fluid inclusions hosted in plutonic and mantle rocks over geologic time scales, which are subsequently extracted by convecting hydrothermal fluids. These findings have profound implications for the flux of 
carbon between the lithosphere and oceans, directly impacting microbial vent communities in seafloor and subseafloor environments that utilize reduced carbon species for their sustenance.

\section{ACKNOWLEDGEMENTS}

I would like to thank Sean Sylva for his analytical expertise and assistance with the GCIRMS system. Thank you to Mark Kurz and Joshua Curtice for performing the helium isotopic measurements. I am indebted to Karmina Aquino and Emmanuel Codillo for collecting and performing Raman analyses on the Zambales ophiolite samples. 
Table 4.1

Hydrocarbon abundances from blank measurements.

\begin{tabular}{|c|c|c|c|c|c|c|}
\hline \multirow[b]{2}{*}{ Blank material } & \multicolumn{2}{|l|}{$\mathrm{CH}_{4}$} & \multicolumn{2}{|l|}{$\mathrm{C}_{2} \mathrm{H}_{6}$} & \multicolumn{2}{|c|}{$\mathrm{CH}_{4} / \mathrm{C}_{2} \mathrm{H}_{6}$} \\
\hline & $\mathrm{nmol} / \mathrm{g}$ & $2 \sigma$ & $\mathrm{nmol} / \mathrm{g}$ & $2 \sigma$ & Avg & $2 \sigma$ \\
\hline Combusted Pyrex beads & 0.07 & 0.03 & 0.0017 & - & 58 & - \\
\hline Combusted ALV 621-3-1 & 0.45 & 0.18 & 0.0007 & 0.0002 & 656 & 109 \\
\hline Combusted ALV 623-3-2 & 0.09 & 0.08 & $b d l$ & & & \\
\hline Combusted ALV 624-3-3 & 0.04 & 0.05 & $b d l$ & & & \\
\hline
\end{tabular}

bdl - below detection limit 


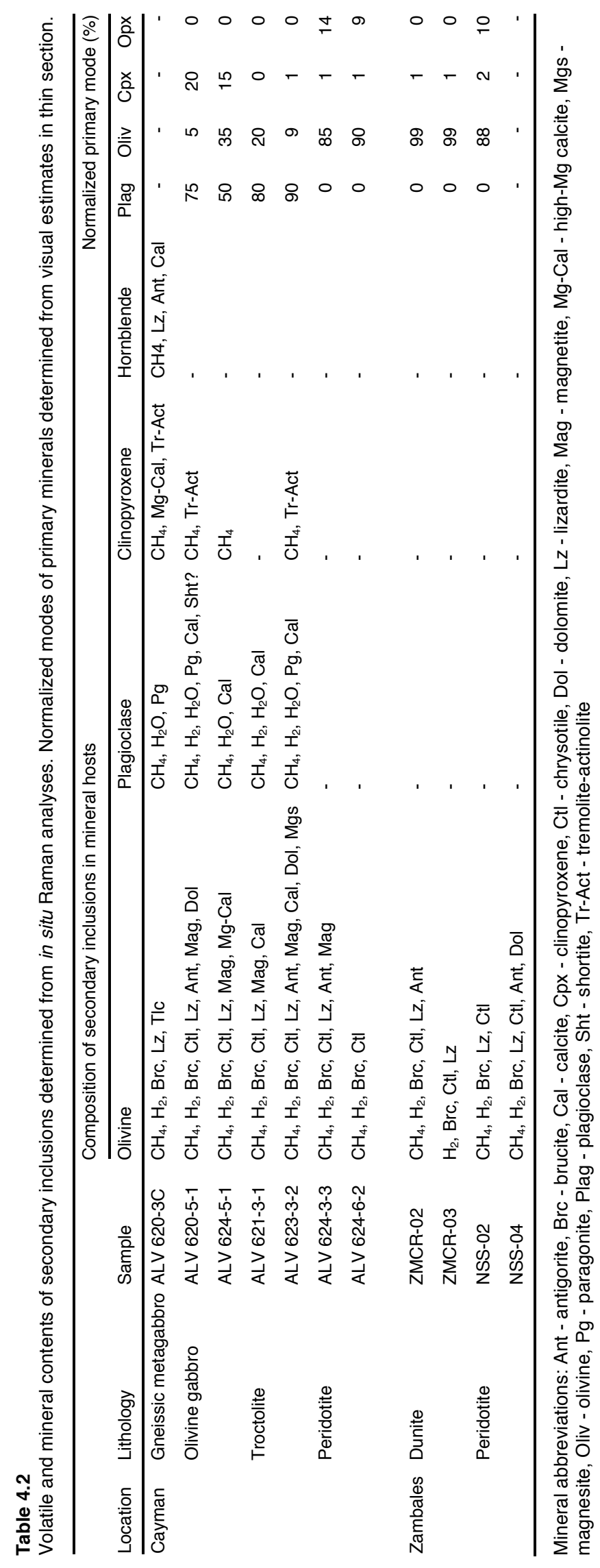




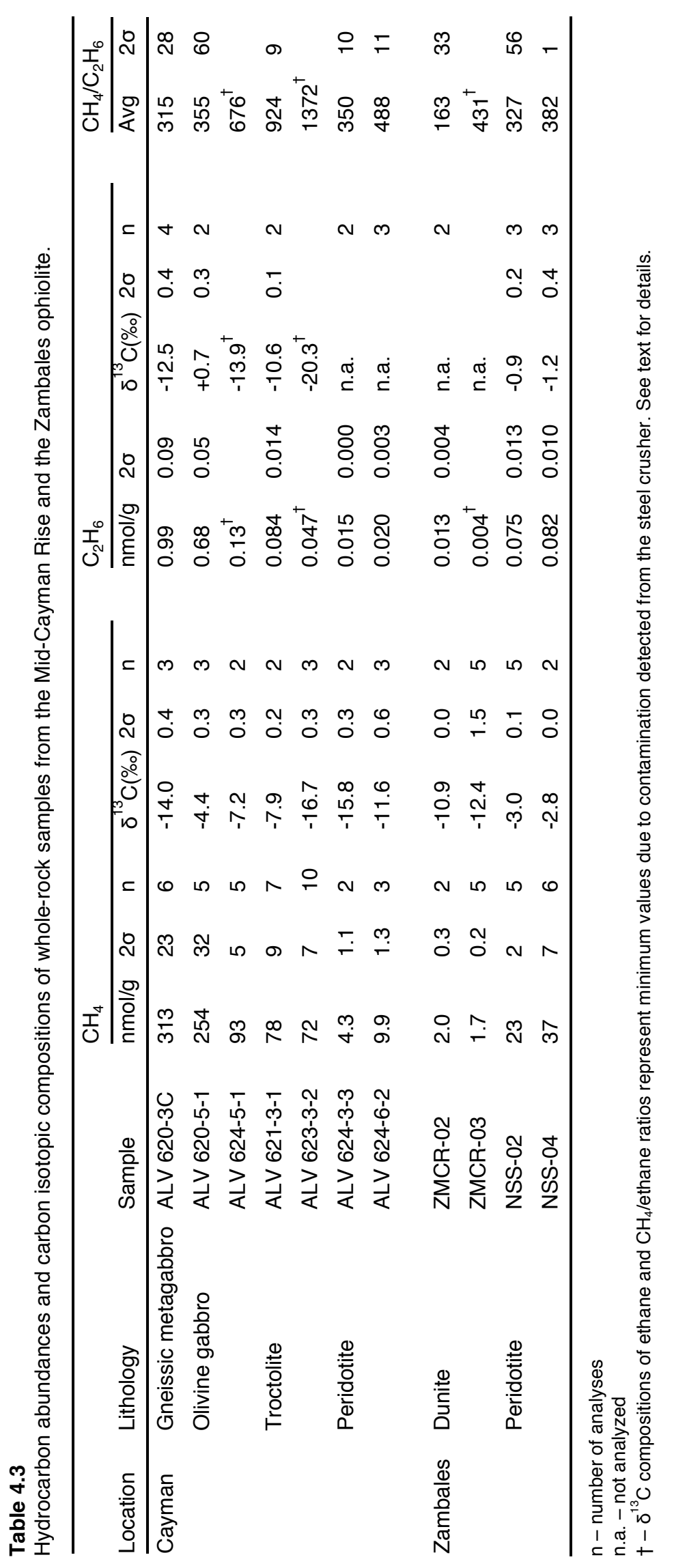


Table 4.4

Helium in whole-rock samples from the Mid-Cayman Rise and the Zambales ophiolite. All measurements were performed by crushing in vacuum.

\begin{tabular}{lllllll}
\hline \multirow{2}{*}{ Location } & Lithology & Sample & $\begin{array}{l}\text { Crush }{ }^{4} \mathrm{He} \\
\text { (cc STP/g) }\end{array}$ & $\begin{array}{l}{ }^{3} \mathrm{He} /{ }^{4} \mathrm{He} \\
(\mathrm{Re} / \mathrm{Ra})\end{array}$ & $2 \sigma$ & $\mathrm{CH}_{4}{ }^{3} \mathrm{He}$ \\
\hline Cayman & Gneissic metagabbro & ALV 620-3C & $4.68 \mathrm{E}-07$ & 8.32 & 0.16 & $1.28 \mathrm{E}+09$ \\
& Olivine gabbro & ALV 620-5-1 & $2.26 \mathrm{E}-09$ & 7.02 & 0.24 & $2.56 \mathrm{E}+11$ \\
& \multirow{6}{*}{ Troctolite } & ALV 624-5-1 & $7.70 \mathrm{E}-09$ & 7.25 & 0.17 & $2.67 \mathrm{E}+10$ \\
& & ALV 621-3-1 & $6.46 \mathrm{E}-09$ & 7.53 & 0.19 & $2.57 \mathrm{E}+10$ \\
& \multirow{2}{*}{ Peridotite } & ALV 623-3-2 & $3.53 \mathrm{E}-08$ & 7.66 & 0.15 & $4.27 \mathrm{E}+09$ \\
& & ALV 624-3-3 & $8.97 \mathrm{E}-11$ & 9.91 & 1.23 & $7.70 \mathrm{E}+10$ \\
& & ALV 624-6-2 & $2.47 \mathrm{E}-10$ & 6.58 & 0.59 & $9.76 \mathrm{E}+10$ \\
\multirow{5}{*}{ Zambales } & Dunite & ZMCR-02 & $1.33 \mathrm{E}-09$ & 3.00 & 0.16 & $8.06 \mathrm{E}+09$ \\
& Peridotite & NSS-02 & $9.12 \mathrm{E}-11$ & 5.57 & 0.92 & $7.23 \mathrm{E}+11$ \\
& & NSS-04 & $1.15 \mathrm{E}-10$ & 4.00 & 1.01 & $1.30 \mathrm{E}+12$ \\
\hline
\end{tabular}


Table 4.5

Calculated water-rock (W/R) mass ratios needed to account for the concentrations of dissolved $\mathrm{CH}_{4}$ and ethane in Von Damm hydrothermal fluids.

\begin{tabular}{llrr}
\hline & & \multicolumn{2}{c}{ W/R } \\
Rock type & Sample & $\mathrm{CH}_{4}$ & Ethane \\
\hline Gneissic metagabbro & ALV 620 3C & 0.11 & 1.56 \\
Olivine gabbro & ALV 620 5-1 & 0.09 & 1.07 \\
& ALV 624 5-1 & 0.03 & 0.21 \\
Troctolite & ALV 621 3-1 & 0.03 & 0.13 \\
& ALV 623 3-2 & 0.03 & 0.07 \\
Peridotite & ALV 624 3-3 & 0.002 & 0.02 \\
& ALV 624 6-2 & 0.004 & 0.03 \\
\hline
\end{tabular}




\section{Figure 4.1}

Bathymetric map of the eastern flank of the Mount Dent oceanic core complex on the MidCayman Rise showing the locations of dive tracks and stations from the Cayman Trough Project. The distribution of rock types is shown for each numbered station. Samples used in this study are highlighted in red circles. The approximate location of the Von Damm hydrothermal field (yellow star) is shown for comparison. Figure modified from Stroup and Fox (1981). 


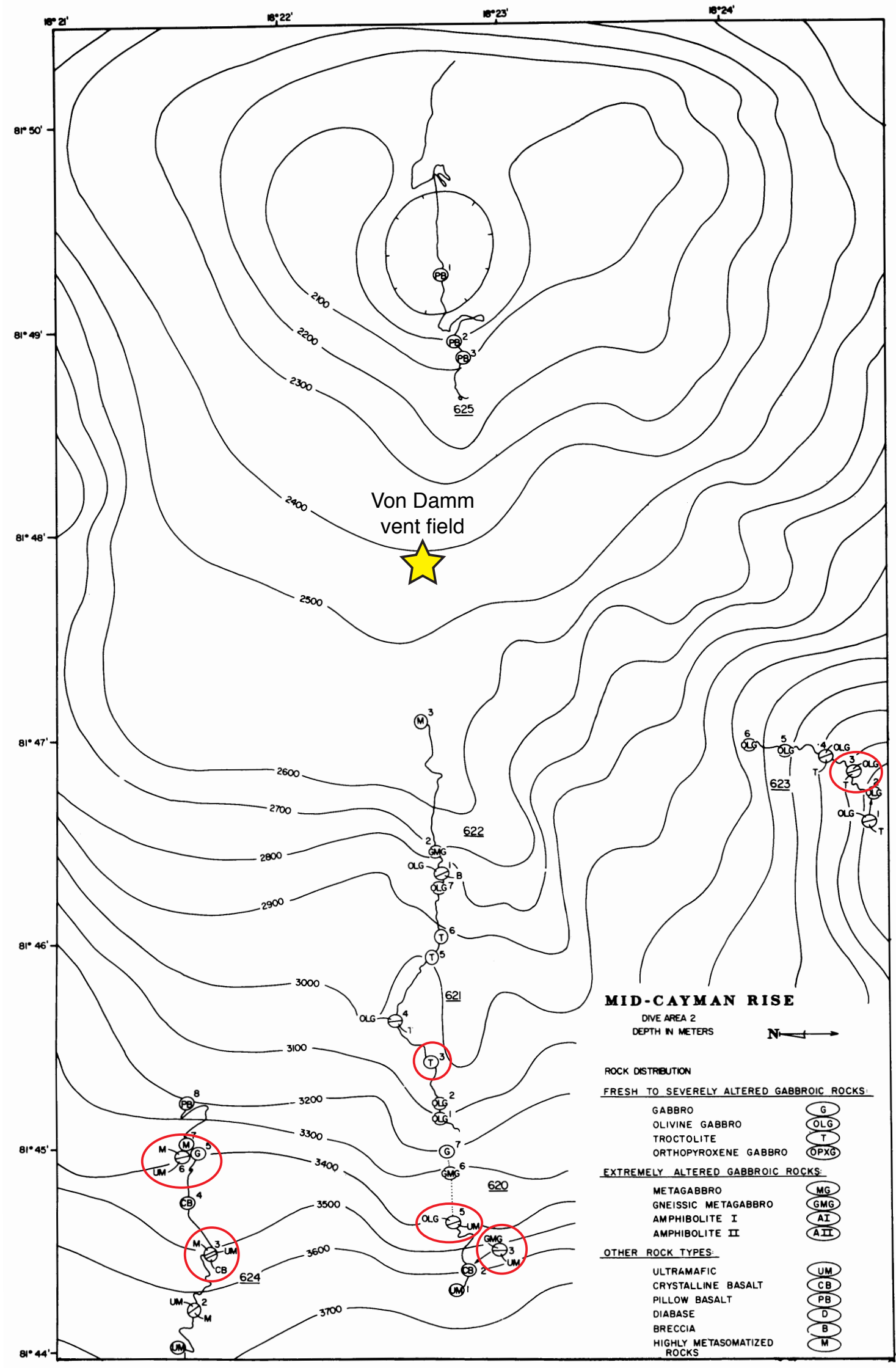




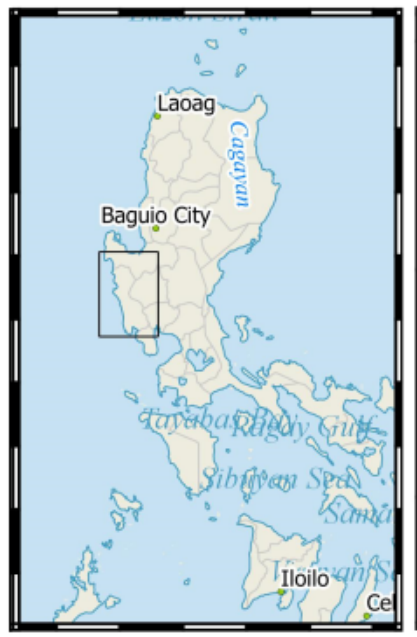

Zambales Ophiolite Complex Acoje Block Coto Block $]$ Masinloc Massif

Cabangan Massif San Antonio Massif

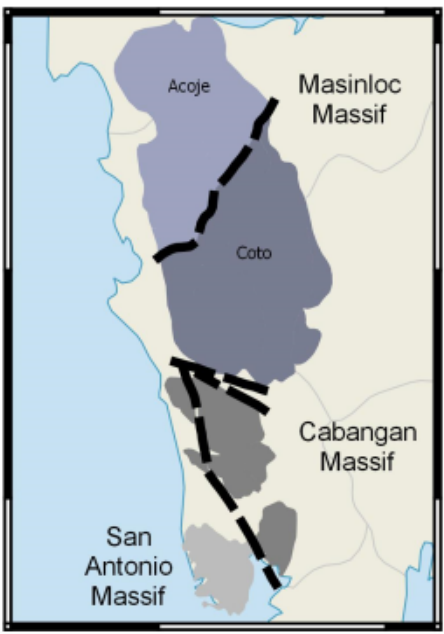

\section{Lithology}

- Fault

Basalt-Diabase

Cummulate rocks Harburgite-Lherzolite

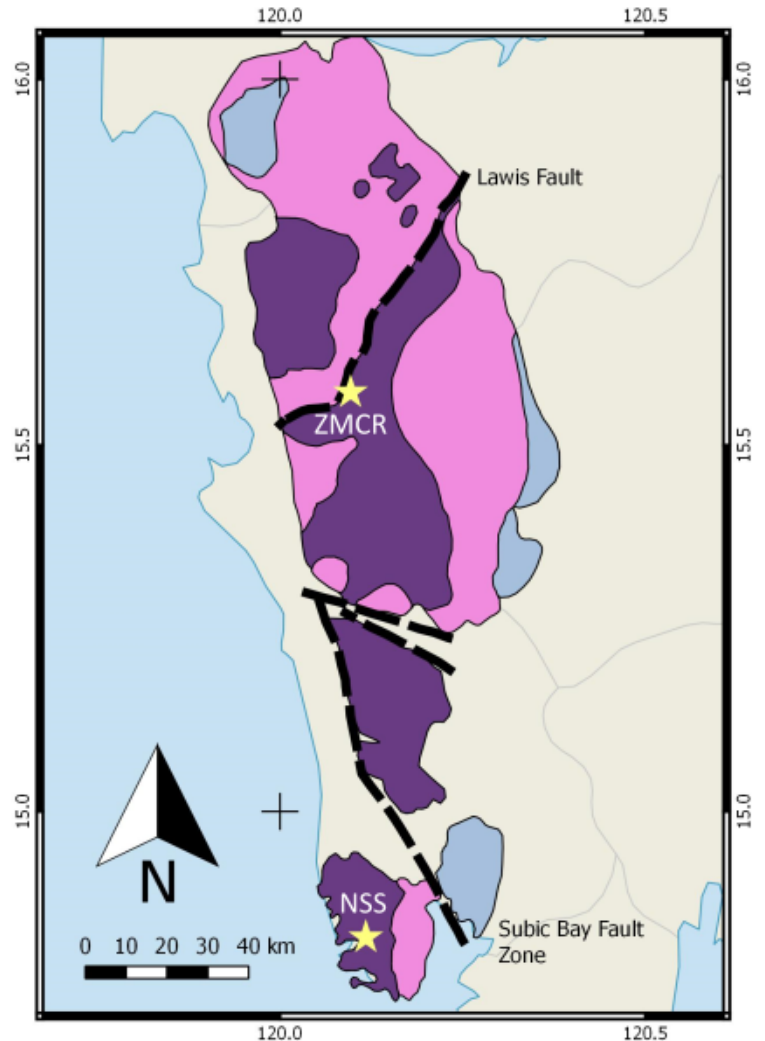

Figure 4.2

Map of the Zambales Ophiolite Complex in the Philippines displaying sampling locations. Figure modified from Dimalanta et al. (2015). 


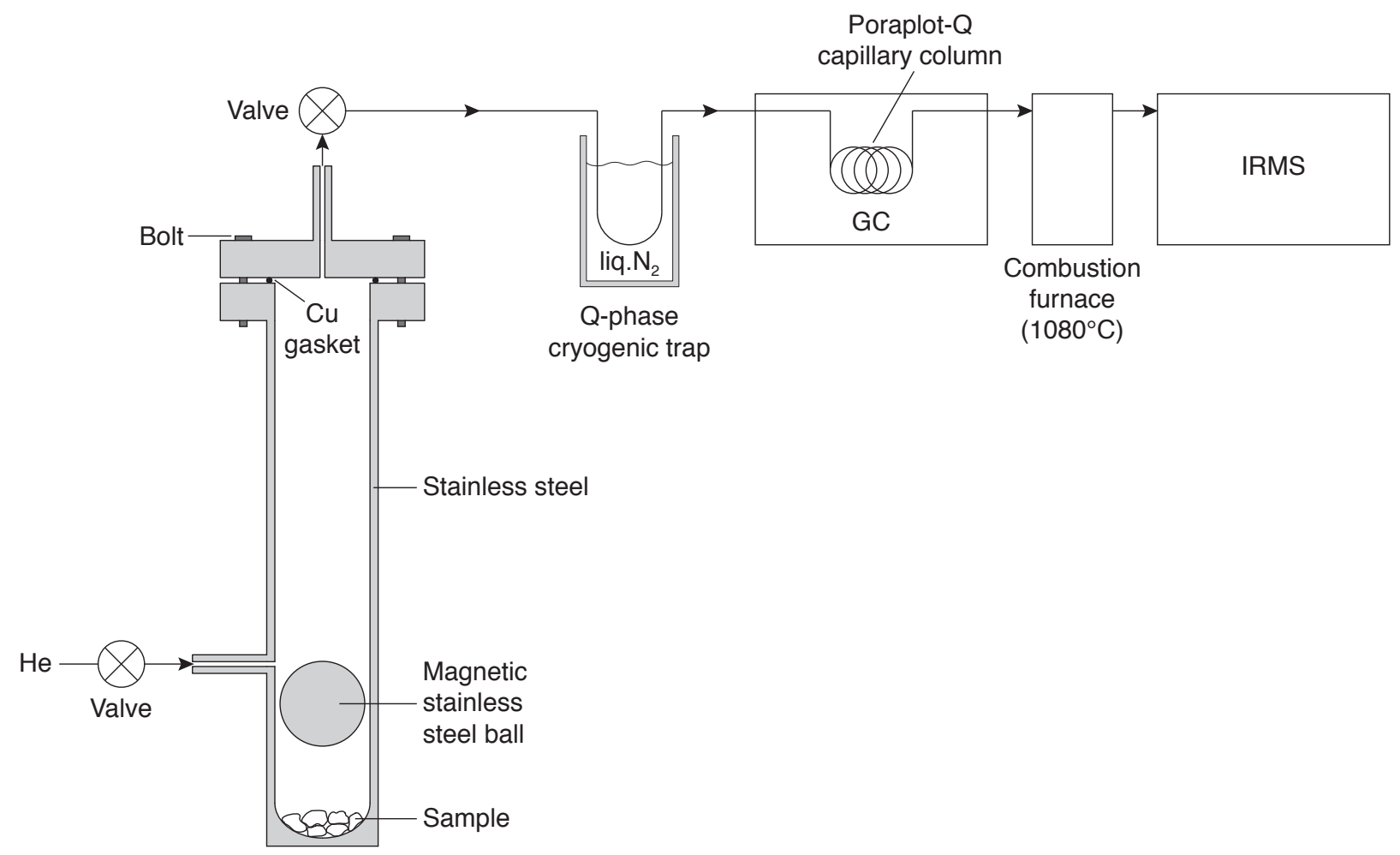

Figure 4.3

Schematic diagram of the stainless steel crushing device in line with a gas chromatographyisotope ratio mass spectroscopy (GC-IRMS) system. 

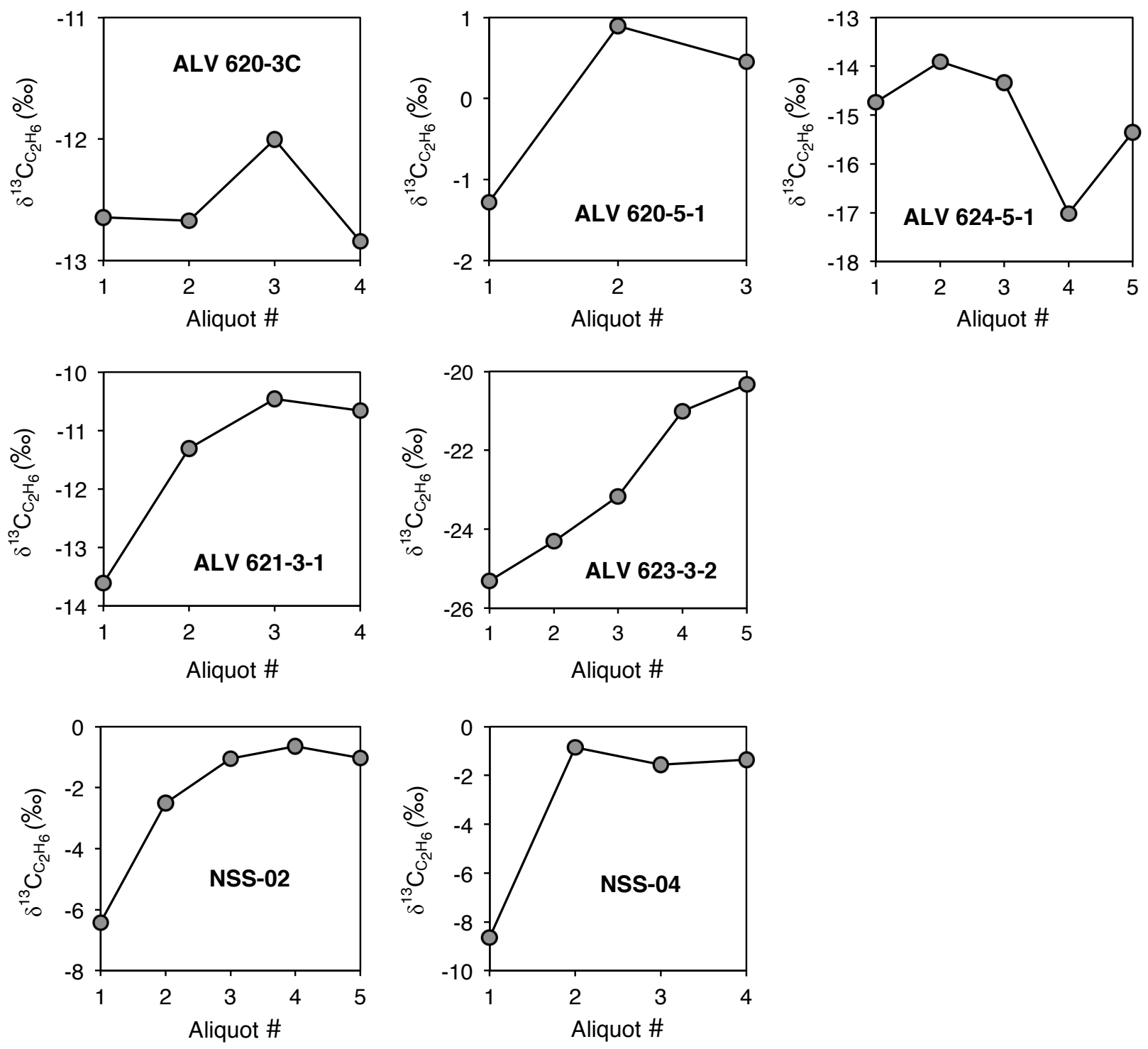

Figure 4.4

Plots showing the changes in $\delta^{13} \mathrm{C}_{\mathrm{C}_{2} \mathrm{H}_{6}}$ values with analysis of successive aliquots of sample material. Most samples from the Mid-Cayman Rise and Zambales ophiolite exhibit more ${ }^{13} \mathrm{C}$ depleted $\mathrm{C}_{2} \mathrm{H}_{6}$ in the first few sample aliquots, which may be attributed to the production of isotopically light $\mathrm{C}_{2} \mathrm{H}_{6}$ from the crushing device. 


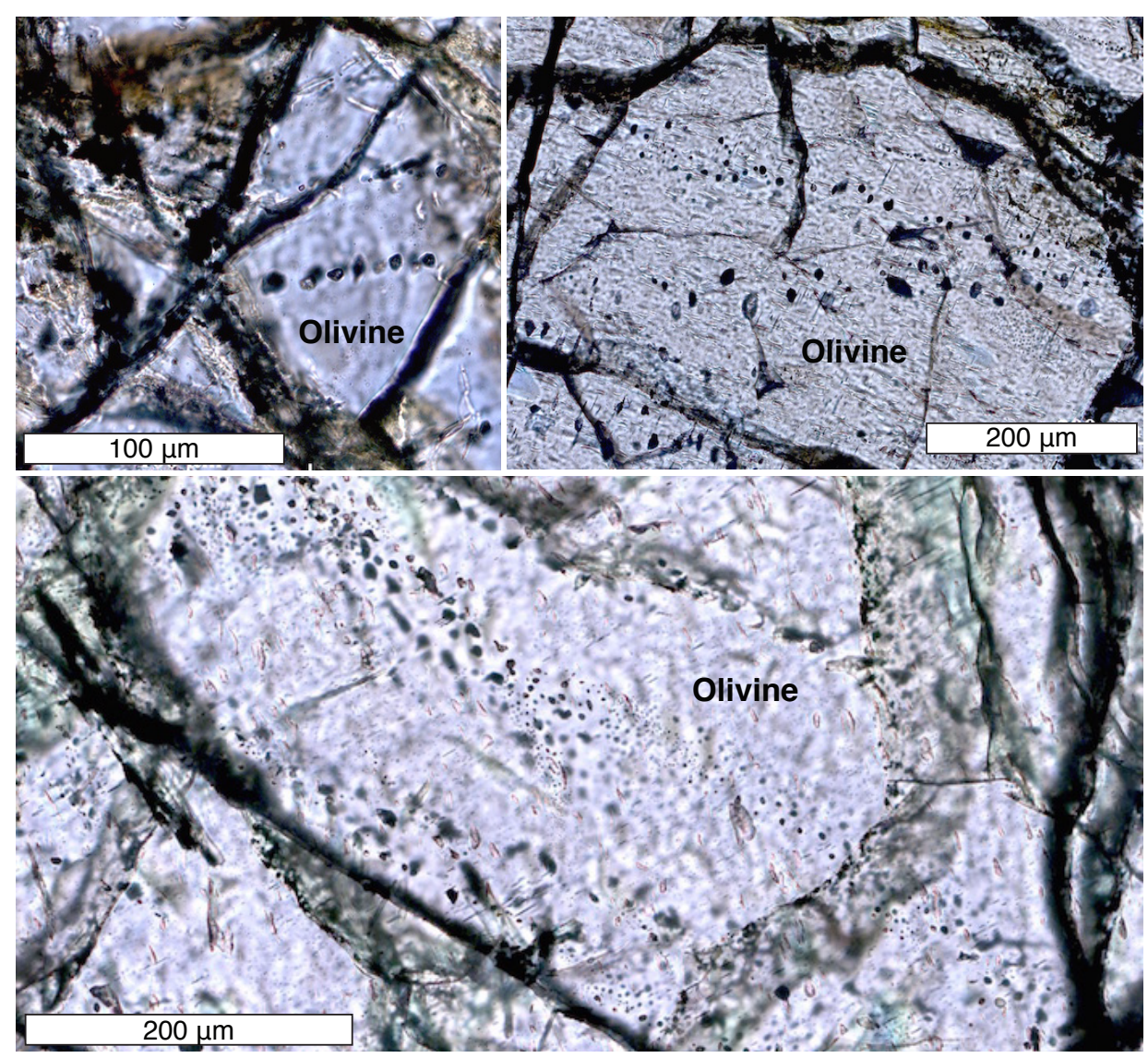

\section{Figure 4.5}

Thin section photomicrographs showing trails of $\mathrm{CH}_{4}$-rich secondary inclusions cross-cutting olivine in troctolite from the Mid-Cayman Rise (Sample ALV 623-3-2; plane-polarized light). 
Figure 4.6

Representative Raman spectra of olivine-hosted secondary inclusions in samples from the MidCayman Rise. Raman band positions for olivine are removed for clarity. Mineral abbreviations: Ant - antigorite, Brc - brucite, Ctl - chrysotile, Lz - lizardite, Mag - magnetite, Mgs - magnesite, Ol - olivine, Srp - serpentine 


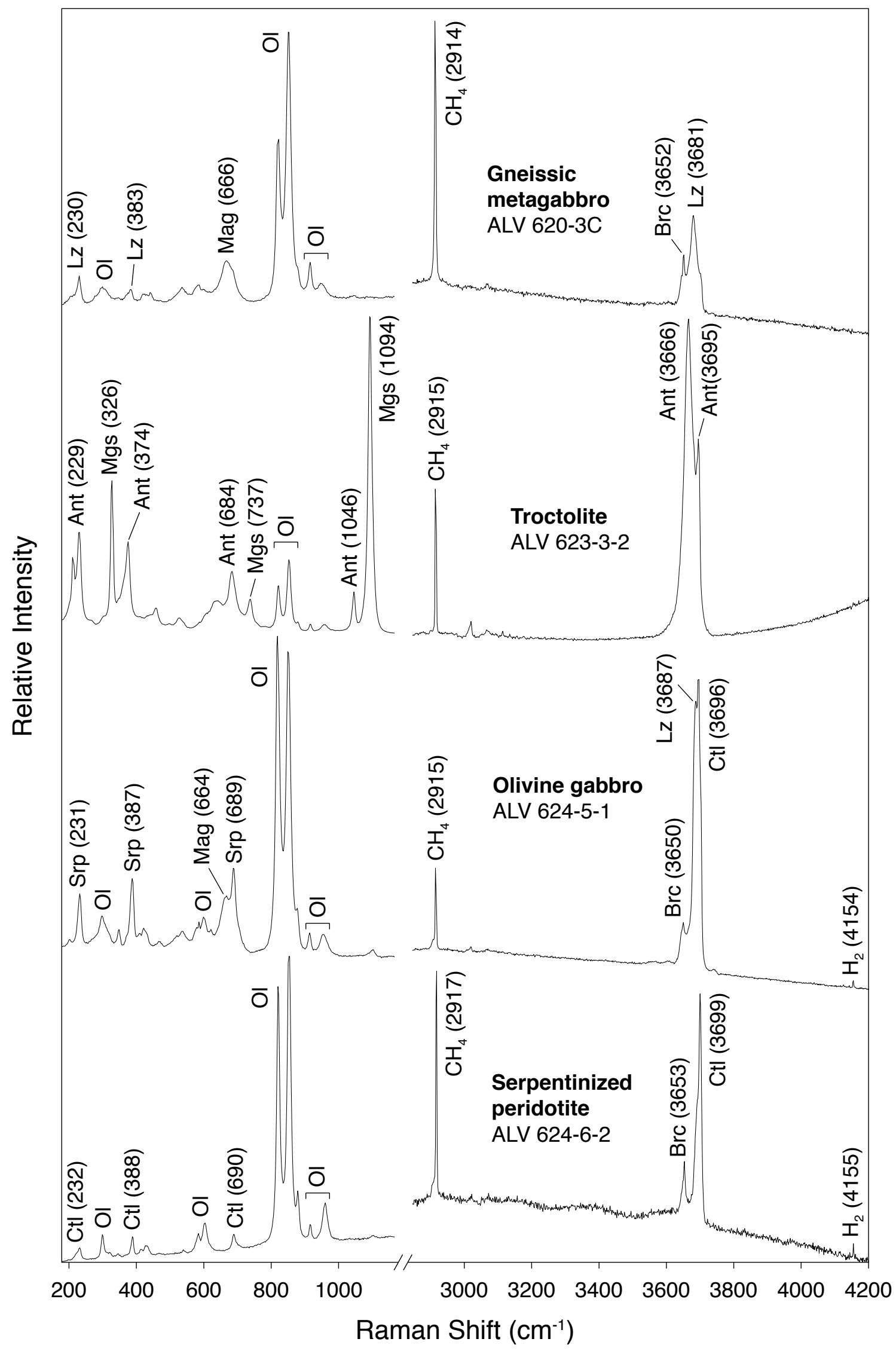



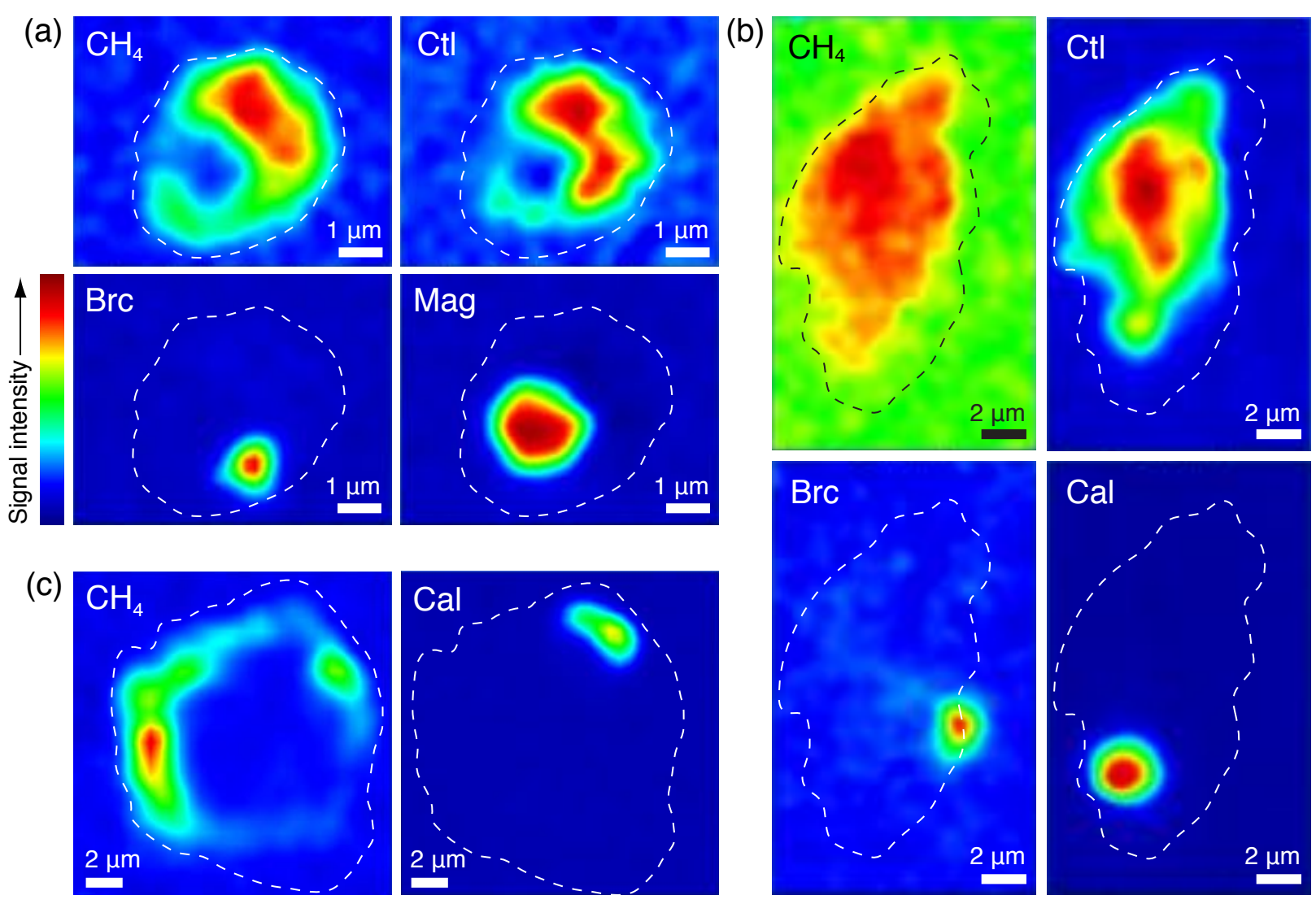

(c)
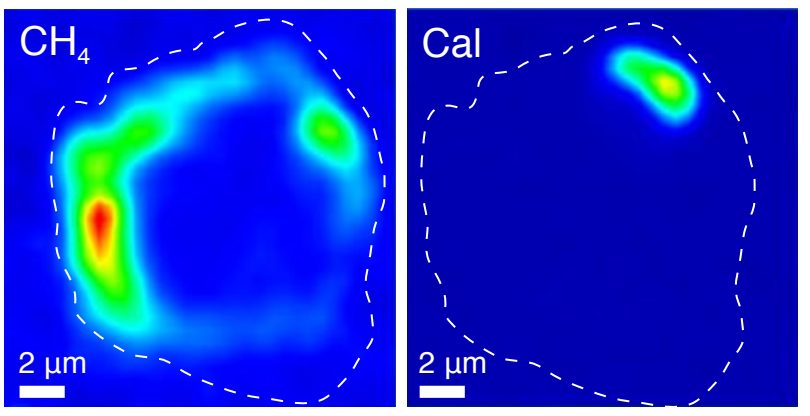

\section{Figure 4.7}

False-color Raman maps showing the locations of mineral and gaseous species in secondary inclusions hosted in olivine (a-b) and plagioclase (c). Colors represent intensities of the characteristic Raman band for a particular phase, with warmer colors indicating higher signal intensities. 


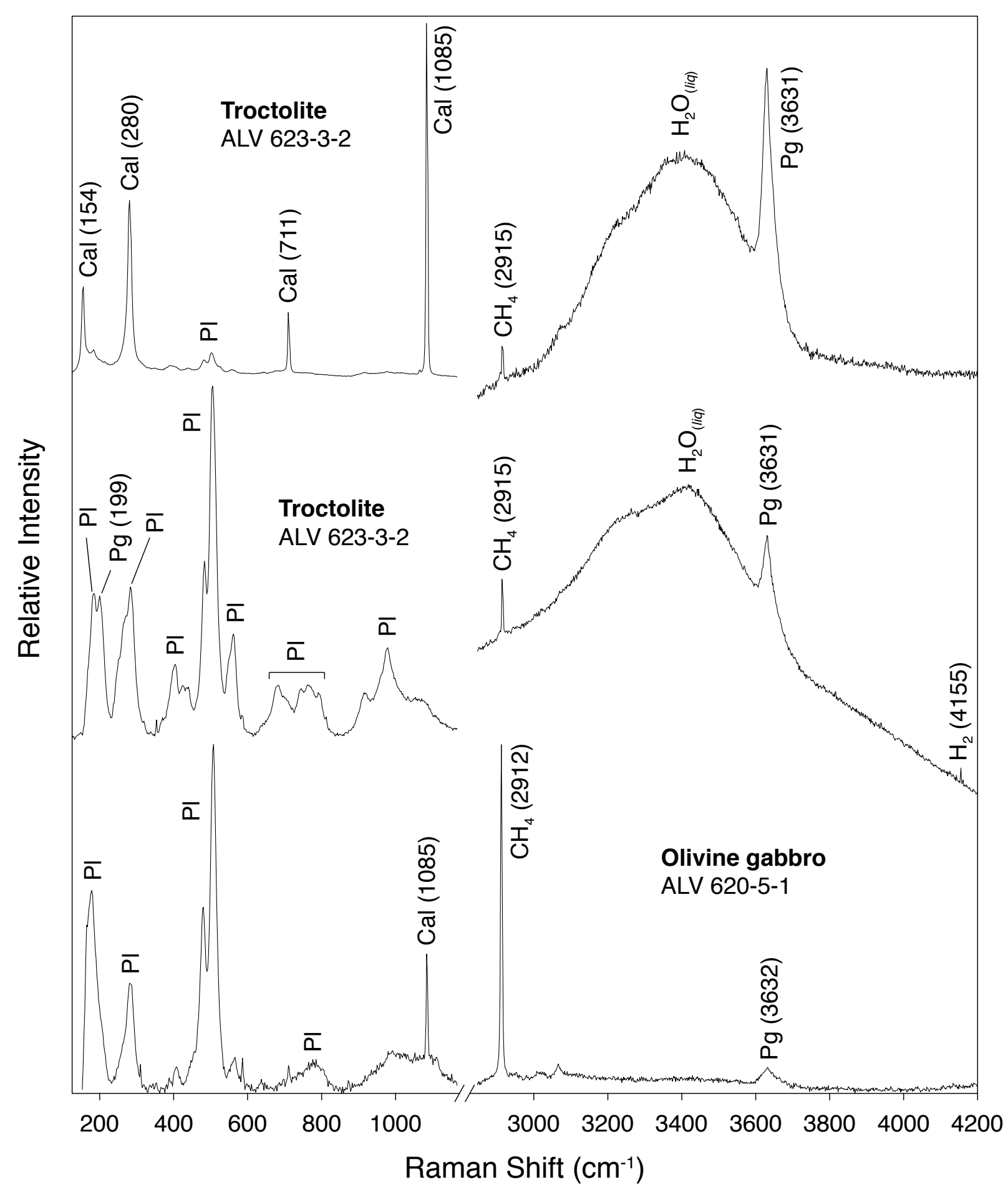

\section{Figure 4.8}

Representative Raman spectra of plagioclase-hosted secondary inclusions in samples from the Mid-Cayman Rise. Raman band positions for plagioclase are removed for clarity. Mineral abbreviations: Cal - calcite, $\mathrm{Pg}$ - paragonite, $\mathrm{Pl}$ - plagioclase 


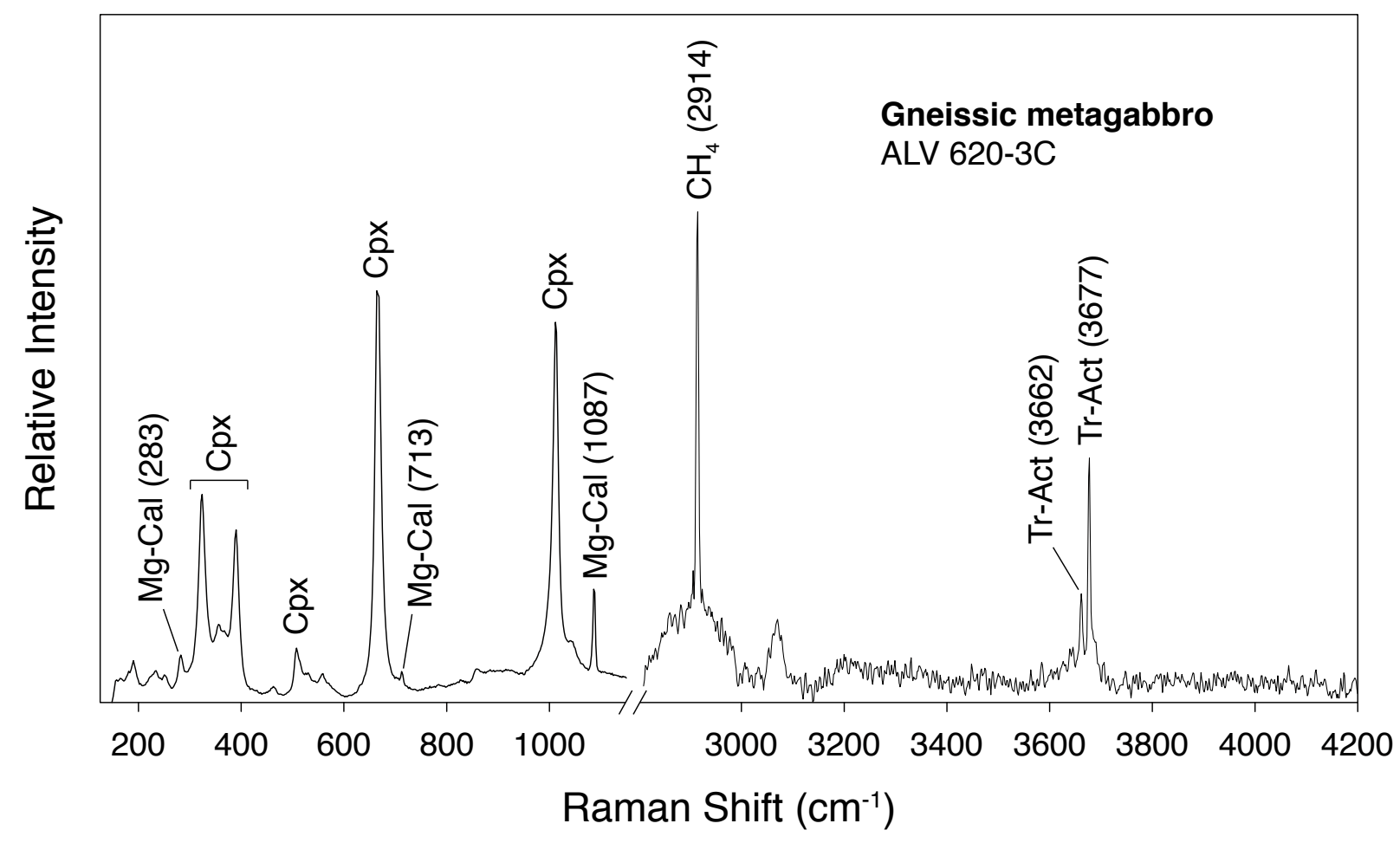

\section{Figure 4.9}

Representative Raman spectrum of a clinopyroxene-hosted secondary inclusion in the gneissic metagabbro sample ALV 620-3C from the Mid-Cayman Rise. Raman band positions for clinopyroxene are removed for clarity. Mineral abbreviations: $\mathrm{Cpx}$ - clinopyroxene, $\mathrm{Mg}-\mathrm{Cal}$ Mg-calcite, Tr-Act - tremolite-actinolite 

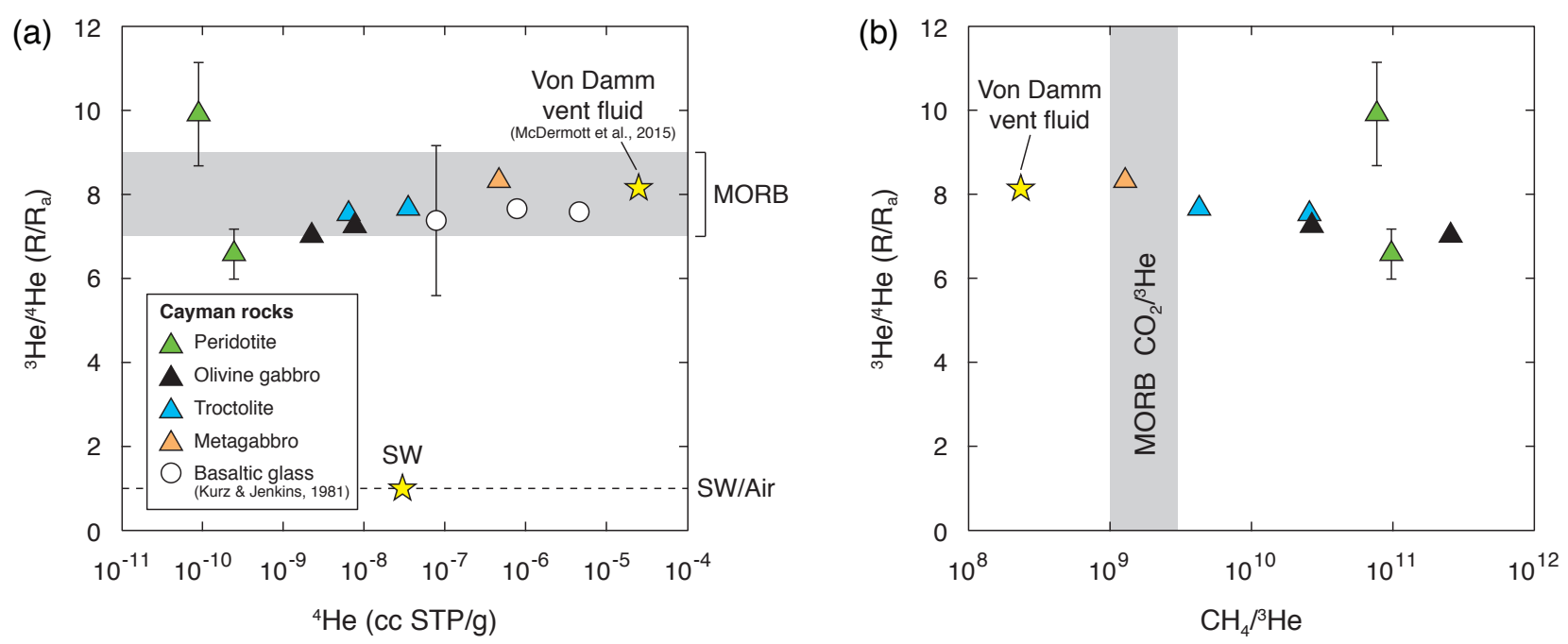

\section{Figure 4.10}

(a) Plot of ${ }^{3} \mathrm{He} /{ }^{4} \mathrm{He}\left(\mathrm{R} / \mathrm{R}_{\mathrm{a}}\right)$ vs. ${ }^{4} \mathrm{He}(\mathrm{cc} \mathrm{STP} / \mathrm{g})$ for whole rock samples from the Mid-Cayman Rise. Plotted for comparison are helium data from Von Damm vent fluid and basaltic glass at Cayman. ${ }^{3} \mathrm{He} /{ }^{4} \mathrm{He}$ ratios in Cayman rocks all show MORB-like values within analytical error, and are consistent with the average ${ }^{3} \mathrm{He} /{ }^{4} \mathrm{He}$ ratio $\left(8.14 \pm 0.13 \mathrm{R}_{\mathrm{a}}\right)$ in Von Damm vent fluids. (b) Plot of ${ }^{3} \mathrm{He} /{ }^{4} \mathrm{He}\left(\mathrm{R} / \mathrm{R}_{\mathrm{a}}\right)$ vs. $\mathrm{CH}_{4} /{ }^{3} \mathrm{He}$. Whole rock samples from Cayman, with the exception of the gneissic metagabbro, all exhibit $\mathrm{CH}_{4} /{ }^{3} \mathrm{He}$ ratios that are significantly higher than the average $\Sigma \mathrm{CO}_{2} /{ }^{3} \mathrm{He}$ ratio for MORB. High $\mathrm{CH}_{4} /{ }^{3} \mathrm{He}$ ratios may reflect inefficient helium extraction by crushing during the helium analyses. 


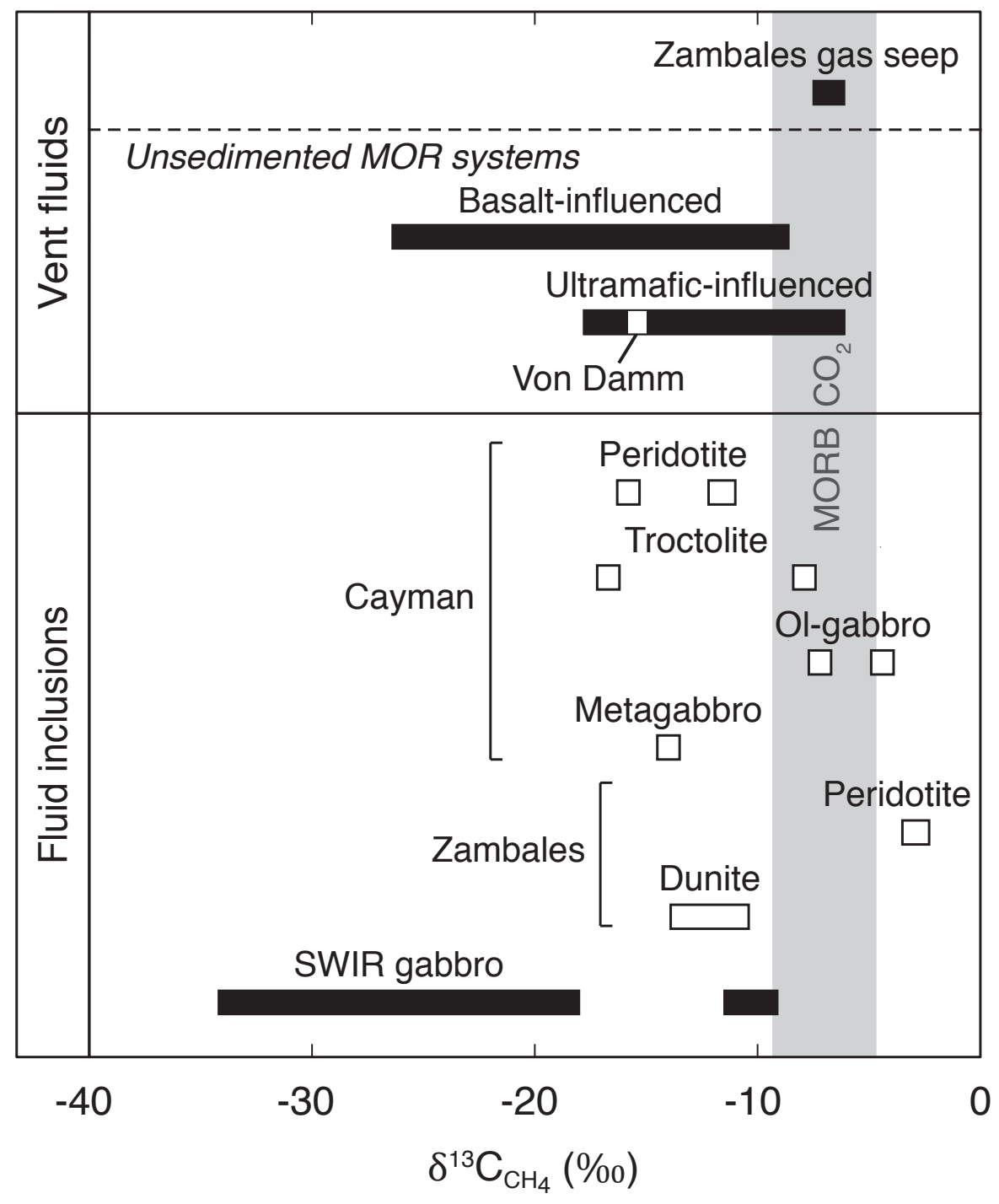

\section{Figure 4.11}

Range in carbon isotopic compositions of $\mathrm{CH}_{4}$ from whole rock samples in this study, Zambales gas seeps, mid-ocean ridge (MOR) vent fluids, and Southwest Indian Ridge (SWIR) gabbros. $\delta^{13} \mathrm{C}_{\mathrm{CH}_{4}}$ values in mafic and ultramafic rocks from Cayman are consistent with the carbon isotopic composition of dissolved $\mathrm{CH}_{4}$ in Von Damm fluids (-15.4\%o), suggesting that $\mathrm{CH}_{4}$ budgets at Von Damm may be influenced by interaction with olivine-rich rocks in the subsurface. The carbon isotopic composition of $\mathrm{CH}_{4}$ in Zambales gas seeps $(-7.0 \pm 0.4 \%$ ) lies in between the ranges of $\delta^{13} \mathrm{C}_{\mathrm{CH}_{4}}$ measured in serpentinized dunite and peridotite from the ophiolite, suggesting that $\mathrm{CH}_{4}$ gas in Zambales may represent a mixed source. Data are from: Welhan and Craig (1983), Des Marais and Moore (1984), Sakai et al. (1984), Merlivat et al. (1987), Abrajano et al. (1988), Evans et al. (1988), Blank et al. (1993), Charlou et al. (1996), Kelley and FrühGreen (1999), Charlou et al. (2000), Gamo et al. (2001), Kelley and Früh-Green (2001), Charlou et al. (2002), Takai et al. (2004), Kelley et al. (2005), Proskurowski et al. (2008), Charlou et al. (2010), and McDermott et al. (2015). 


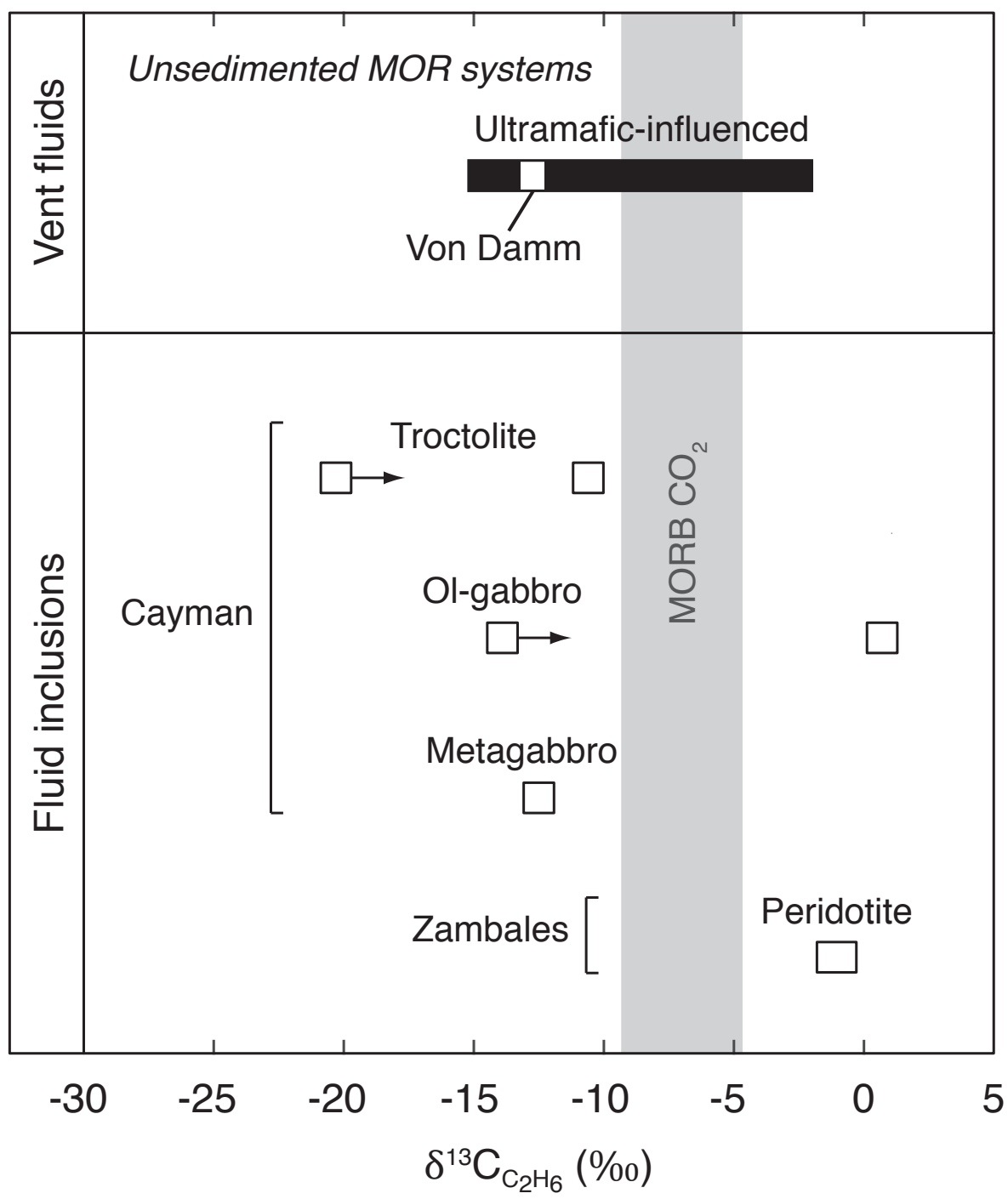

\section{Figure 4.12}

Range in carbon isotopic compositions of $\mathrm{C}_{2} \mathrm{H}_{6}$ from whole rock samples in this study and ultramafic-influenced MOR vent fluids. Symbols with arrows denote minimum values due to $\mathrm{C}_{2} \mathrm{H}_{6}$ contamination detected from the crushing device (see text for details). The carbon isotopic composition of $\mathrm{C}_{2} \mathrm{H}_{6}$ in Von Damm fluids (-12.7\%o) is similar to $\delta^{13} \mathrm{C}_{\mathrm{C}_{2} \mathrm{H}_{6}}$ values for most Cayman samples, with the exception of ALV 620-5-1. Data are from: Des Marais and Moore (1984), Sakai et al. (1984), Blank et al. (1993), Proskurowski et al. (2008), Charlou et al. (2010), and McDermott et al. (2015). 


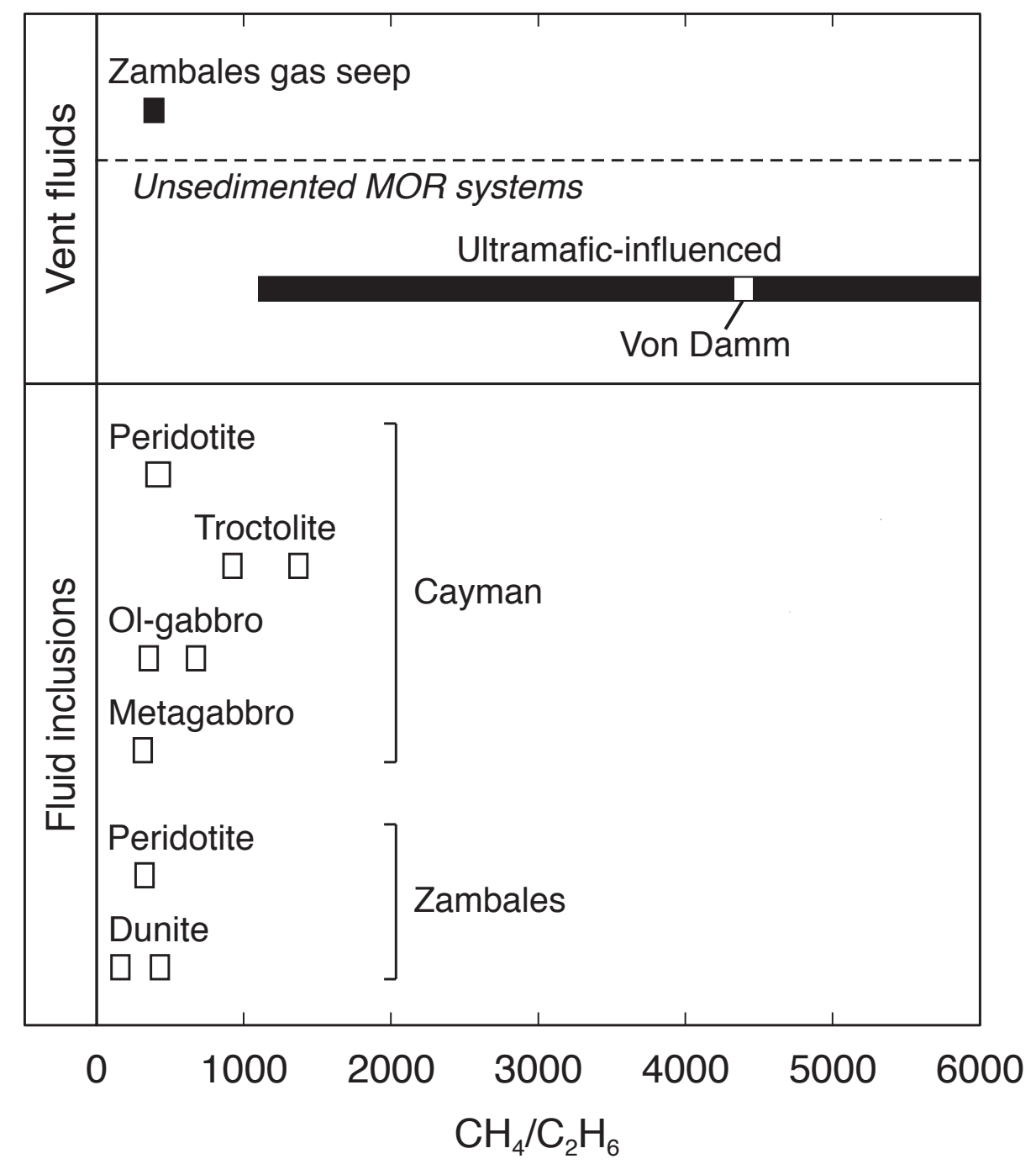

Figure 4.13

Range in $\mathrm{CH}_{4} / \mathrm{C}_{2} \mathrm{H}_{6}$ ratios from whole rock samples in this study, Zambales gas seeps, and ultramafic-influenced MOR vent fluids. $\mathrm{CH}_{4} / \mathrm{C}_{2} \mathrm{H}_{6}$ ratios in Zambales gas seeps match well with measured ratios in serpentinized dunite and peridotite from the ophiolite. In contrast, $\mathrm{CH}_{4} / \mathrm{C}_{2} \mathrm{H}_{6}$ ratios in Von Damm vent fluids are more than three times higher than those in Cayman rocks. Data are from: Abrajano et al. (1988), Charlou et al. (2002), Proskurowski et al. (2008), Charlou et al. (2010), and McDermott et al. (2015). 


\section{REFERENCES}

Abell P. I., Draffan C. H., Eglinton G., Hayes J. M., Maxwell J. R. and Pillinger C. T. (1970) Organic analysis of the returned Apollo 11 lunar sample. Proc. Apollo 11 Lunar Sci. Conf. 2, 1757-1773.

Abrajano T. A. (1984) Igneous petrology and low temperature geochemistry of the Acoje massif, Zambales Ophiolite, Philippines: Mineralogical, isotopic, and mixed-volatile equilibria. Ph.D. thesis, Washington University in St. Louis.

Abrajano T. A., Sturchio N. C., Bohlke J. K., Lyon G. L., Poreda R. J. and Stevens C. M. (1988) Methane-hydrogen gas seeps, Zambales Ophiolite, Philippines: Deep or shallow origin? Chem. Geol. 71, 211-222.

Abrajano T. A., Sturchio N. C., Kennedy B. M., Lyon G. L., Muehlenbachs K. and Bohlke J. K. (1990) Geochemistry of reduced gas related to serpentinization of the Zambales ophiolite, Philippines. Appl. Geochemistry 5, 625-630.

Allègre C. J., Staudacher T., Sarda P. and Kurz M. D. (1983) Constraints on evolution of Earth's mantle from rare gas systematics. Nature 303, 762-766.

Allen D. E. and Seyfried W. E. J. (2004) Serpentinization and heat generation: Constraints from Lost City and Rainbow hydrothermal systems. Geochim. Cosmochim. Acta 68, 1347-1354.

Alt J. C., Schwarzenbach E. M., Früh-Green G. L., Shanks W. C., Bernasconi S. M., Garrido C. J., Crispini L., Gaggero L., Padrón-Navarta J. A. and Marchesi C. (2013) The role of serpentinites in cycling of carbon and sulfur: Seafloor serpentinization and subduction metamorphism. Lithos 178, 40-54.

Andrawes F. F. and Gibson E. K. J. (1979) Release and analysis of gases from geological samples. Am. Mineral. 64, 453-463.

Andrawes F., Holzer G., Roedder E., Gibson E. K. J. and Oro J. (1984) Gas chromatographic analysis of volatiles in fluid and gas inclusions. J. Chromatogr. 302, 181-193.

Bach W., Alt J. C., Niu Y., Humphris S. E., Erzinger J. and Dick H. J. B. (2001) The geochemical consequences of late-stage low-grade alteration of lower ocean crust at the SW Indian Ridge: Results from ODP Hole 735B (Leg 176). Geochim. Cosmochim. Acta 65 , 3267-3287.

Bach W., Rosner M., Jöns N., Rausch S., Robinson L. F., Paulick H. and Erzinger J. (2011) Carbonate veins trace seawater circulation during exhumation and uplift of mantle rock: Results from ODP Leg 209. Earth Planet. Sci. Lett. 311, 242-252.

Baines A. G., Cheadle M. J., John B. E., Grimes C. B., Schwartz J. J. and Wooden J. L. (2009) $\mathrm{SHRIMP} \mathrm{Pb} / \mathrm{U}$ zircon ages constrain gabbroic crustal accretion at Atlantis Bank on the ultraslow-spreading Southwest Indian Ridge. Earth Planet. Sci. Lett. 287, 540-550.

Ballard R., Bryan W., Dick H., Emery K. O., Thompson G., Uchupi E., Davis K. E., de Boer J., DeLong S. E., Fox P. J., Malcolm F. L., Spydell R., Stroup J., Melson W. G. and Wright R. (1979) Geological and geophysical investigation of the Midcayman Rise spreading center: Initial results and observations. In Deep Drilling Results in the Atlantic Ocean: Ocean Crust (eds. M. Talwani, C. G. Harrison, and D. E. Hayes). American Geophysical Union, Washington, D. C. pp. 66-93.

Blank J. G., Delaney J. R. and Des Marais D. J. (1993) The concentration and isotopic composition of carbon in basaltic glasses from the Juan de Fuca Ridge, Pacific Ocean. Geochim. Cosmochim. Acta 57, 875-887.

Boschetti T., Etiope G. and Toscani L. (2013) Abiotic methane in the hyperalkaline springs of 
Genova, Italy. Procedia Earth Planet. Sci. 7, 248-251.

Buck W. R. (1991) Modes of continental lithospheric extension. J. Geophys. Res. 96, 20,16120,178 .

Chacko T., Cole D. R. and Horita J. (2001) Equilibrium oxygen, hydrogen and carbon isotope fractionation factors applicable to geologic systems. Rev. Mineral. Geochemistry 43, 1-81.

Charlou J. L., Fouquet Y., Donval J. P., Auzende J. M., Jean-Baptiste P., Stievenard M. and Michel S. (1996) Mineral and gas chemistry of hydrothermal fluids on an ultrafast spreading ridge: East Pacific Rise, $17^{\circ}$ to $19^{\circ} \mathrm{S}$ (Naudur cruise, 1993) phase separation processes controlled by volcanic and tectonic activity. J. Geophys. Res. 101, 15,899-15,919.

Charlou J. L., Donval J. P., Douville E., Jean-Baptiste P., Radford-Knoery J., Fouquet Y., Dapoigny A. and Stievenard M. (2000) Compared geochemical signatures and the evolution of Menez Gwen $\left(35^{\circ} 50^{\prime} \mathrm{N}\right)$ and Lucky Strike $\left(37^{\circ} 17^{\prime} \mathrm{N}\right)$ hydrothermal fluids, south of the Azores Triple Junction on the Mid-Atlantic Ridge. Chem. Geol. 171, 49-75.

Charlou J. L., Donval J. P., Fouquet Y., Jean-Baptiste P. and Holm N. (2002) Geochemistry of high $\mathrm{H}_{2}$ and $\mathrm{CH}_{4}$ vent fluids issuing from ultramafic rocks at the Rainbow hydrothermal field (36 14 'N, MAR). Chem. Geol. 191, 345-359.

Charlou J. L., Donval J. P., Konn C., Ondréas H., Fouquet Y., Jean-Baptiste P. and Fourré E. (2010) High production and fluxes of $\mathrm{H}_{2}$ and $\mathrm{CH}_{4}$ and evidence of abiotic hydrocarbon synthesis by serpentinization in ultramafic-hosted hydrothermal systems on the MidAtlantic Ridge. In Diversity Of Hydrothermal Systems On Slow Spreading Ocean Ridges (eds. P. A. Rona, C. W. Devey, J. Dyment, and B. J. Murton). American Geophysical Union, Washington, D. C. pp. 265-296.

Deines P. (2002) The carbon isotope geochemistry of mantle xenoliths. Earth Sci. Rev. 58, $247-$ 278.

Delacour A., Früh-Green G. L., Bernasconi S. M., Schaeffer P. and Kelley D. S. (2008) Carbon geochemistry of serpentinites in the Lost City Hydrothermal System $\left(30^{\circ} \mathrm{N}, \mathrm{MAR}\right)$. Geochim. Cosmochim. Acta 72, 3681-3702.

Des Marais D. J. and Moore J. G. (1984) Carbon and its isotopes in mid-oceanic basaltic glasses. Earth Planet. Sci. Lett. 69, 43-57.

Dimalanta C. B., Salapare R. C., Faustino-Eslava D. V., Ramos N. T., Queaño K. L., Yumul G. P. and Yang T. F. (2015) Post-emplacement history of the Zambales Ophiolite Complex: Insights from petrography, geochronology and geochemistry of Neogene clastic rocks. $J$. Asian Earth Sci. 104, 215-227.

Duan Z. and Sun R. (2003) An improved model calculating $\mathrm{CO}_{2}$ solubility in pure water and aqueous $\mathrm{NaCl}$ solutions from 273 to $533 \mathrm{~K}$ and from 0 to 2000 bar. Chem. Geol. 193, 257271.

Eickmann B., Bach W. and Peckmann J. (2009) Authigenesis of carbonate minerals in modern and Devonian ocean-floor hard rocks. J. Geol. 117, 307-323.

Elthon D. (1987) Petrology of gabbroic rocks from the Mid-Cayman rise spreading center. $J$. Geophys. Res. 92, 658-682.

Etiope G., Schoell M. and Hosgörmez H. (2011) Abiotic methane flux from the Chimaera seep and Tekirova ophiolites (Turkey): Understanding gas exhalation from low temperature serpentinization and implications for Mars. Earth Planet. Sci. Lett. 310, 96-104.

Etiope G., Tsikouras B., Kordella S., Ifandi E., Christodoulou D. and Papatheodorou G. (2013) Methane flux and origin in the Othrys ophiolite hyperalkaline springs, Greece. Chem. Geol. 347, 161-174. 
Evans W. C., White L. D. and Rapp J. B. (1988) Geochemistry of some gases in hydrothermal fluids from the southern Juan de Fuca Ridge. J. Geophys. Res. 93, 15,305-15,313.

Foustoukos D. I. and Seyfried W. E. J. (2004) Hydrocarbons in hydrothermal vent fluids: The role of chromium-bearing catalysts. Science 304, 1002-1005.

Foustoukos D. I., Savov I. P. and Janecky D. R. (2008) Chemical and isotopic constraints on water/rock interactions at the Lost City hydrothermal field, $30^{\circ} \mathrm{N}$ Mid-Atlantic Ridge. Geochim. Cosmochim. Acta 72, 5457-5474.

Fu Q., Sherwood Lollar B., Horita J., Lacrampe-Couloume G. and Seyfried W. E. J. (2007) Abiotic formation of hydrocarbons under hydrothermal conditions: Constraints from chemical and isotope data. Geochim. Cosmochim. Acta 71, 1982-1998.

Gamo T., Chiba H., Yamanaka T., Okudaira T., Hashimoto J., Tsuchida S., Ishibashi J., Kataoka S., Tsunogai U., Okamura K., Sano Y. and Shinjo R. (2001) Chemical characteristics of newly discovered black smoker fluids and associated hydrothermal plumes at the Rodriguez Triple Junction, Central Indian Ridge. Earth Planet. Sci. Lett. 193, 371-379.

German C. R., Petersen S. and Hannington M. D. (2016) Hydrothermal exploration of mid-ocean ridges: Where might the largest sulfide deposits be forming? Chem. Geol. 420, 114-126.

Grimes C. B., John B. E., Cheadle M. J. and Wooden J. L. (2008) Protracted construction of gabbroic crust at a slow spreading ridge: Constraints from ${ }^{206} \mathrm{~Pb} /{ }^{238} \mathrm{U}$ zircon ages from Atlantis Massif and IODP Hole U1309D (30N, MAR). Geochemistry, Geophys. Geosystems 9, Q08012, doi:10.1029/2008GC002063.

Grimes C. B., Cheadle M. J., John B. E., Reiners P. W. and Wooden J. L. (2011) Cooling rates and the depth of detachment faulting at oceanic core complexes: Evidence from zircon $\mathrm{Pb} / \mathrm{U}$ and (U-Th)/He ages. Geochemistry, Geophys. Geosystems 12, Q0AG01, doi:10.1029/2010GC003391.

Hiyagon H., Ozima M., Marty B., Zashu S. and Sakai H. (1992) Noble gases in submarine glasses from mid-oceanic ridges and Loihi seamount: Constraints on the early history of the Earth. Geochim. Cosmochim. Acta 56, 1301-1316.

Horita J. and Berndt M. E. (1999) Abiogenic methane formation and isotopic fractionation under hydrothermal conditions. Science 2, 1055-1057.

Hosgormez H., Etiope G. and Yalçin M. N. (2008) New evidence for a mixed inorganic and organic origin of the Olympic Chimaera fire (Turkey): A large onshore seepage of abiogenic gas. Geofluids 8, 263-273.

John B. E., Foster D. A., Murphy J. M., Cheadle M. J., Baines A. G., Fanning C. M. and Copeland P. (2004) Determining the cooling history of in situ lower oceanic crust-Atlantis Bank, SW Indian Ridge. Earth Planet. Sci. Lett. 222, 145-160.

Jones L. C., Rosenbauer R., Goldsmith J. I. and Oze C. (2010) Carbonate control of $\mathrm{H}_{2}$ and $\mathrm{CH}_{4}$ production in serpentinization systems at elevated P-Ts. Geophys. Res. Lett. 37, L14306, doi:10.1029/2010GL043769.

Kadko D. and Butterfield D. A. (1998) The relationship of hydrothermal fluid composition and crustal residence time to maturity of vent fields on the Juan de Fuca Ridge. Geochim. Cosmochim. Acta 62, 1521-1533.

Kadko D. and Moore W. (1988) Radiochemical constraints on the crustal residence time of submarine hydrothermal fluids: Endeavor Ridge. Geochim. Cosmochim. Acta 52, 659-668.

Kelley D. S. (1996) Methane-rich fluids in the oceanic crust. J. Geophys. Res. Earth 101, 29432962.

Kelley D. S. and Früh-Green G. L. (1999) Abiogenic methane in deep-seated mid-ocean ridge 
environments: Insights from stable isotope analyses. $J$. Geophys. Res. 104, 10,439-10,460.

Kelley D. S. and Früh-Green G. L. (2001) Volatile lines of descent in submarine plutonic environments: Insights from stable isotope and fluid inclusion analyses. Geochim. Cosmochim. Acta 65, 3325-3346.

Kelley D. S., Karson J. A., Blackman D. K., Früh-Green G. L., Butterfield D. A., Lilley M. D., Olson E. J., Schrenk M. O., Roe K. K., Lebon G. T., Rivizzigno P. and AT3-60 Shipboard Party. (2001) An off-axis hydrothermal vent field near the Mid-Atlantic Ridge at $30^{\circ} \mathrm{N}$. Nature 412, 145-149.

Kelley D. S., Karson J. A., Früh-Green G. L., Yoerger D. R., Shank T. M., Butterfield D. A., Hayes J. M., Schrenk M. O., Olson E. J., Proskurowski G., Jakuba M., Bradley A., Larson B., Ludwig K., Glickson D., Buckman K., Bradley A. S., Brazelton W. J., Roe K., Bernasconi S. M., Elend M. J., Lilley M. D., Baross J. A., Summons R. E. and Sylva S. P. (2005) A serpentinite-hosted ecosystem: The Lost City hydrothermal field. Science 307, $1428-1434$.

Kirby S. H. and Kronenberg A. K. (1987) Rheology of the lithosphere: Selelcted topics. Rev. Geophys. 25, 1219-1244.

Klein F., Humphris S. E., Guo W., Schubotz F., Schwarzenbach E. M. and Orsi W. D. (2015) Fluid mixing and the deep biosphere of a fossil Lost City-type hydrothermal system at the Iberia Margin. Proc. Natl. Acad. Sci. 112, 12,036-12,041.

Kurz M. D. and Jenkins W. J. (1981) The distribution of helium in oceanic basalt glasses. Earth Planet. Sci. Lett. 53, 41-54.

Kurz M. D., Gurney J. J., Jenkins W. J. and Lott D. E. (1987) Helium isotopic variability within single diamonds from the Orapa kimberlite pipe. Earth Planet. Sci. Lett. 86, 57-68.

Kurz M. D., Curtice J., Lott D. E. and Solow A. (2004) Rapid helium isotopic variability in Mauna Kea shield lavas from the Hawaiian Scientific Drilling Project. Geochemistry, Geophys. Geosystems 5, Q04G14, doi:10.1029/2002GC000439.

Kurz M. D., Warren J. M. and Curtice J. (2009) Mantle deformation and noble gases: Helium and neon in oceanic mylonites. Chem. Geol. 266, 10-18.

Lamadrid H. M. (2016) Geochemistry of fluid-rock processes. Ph.D thesis, Virginia Polytechnic Institute and State University.

Lang S. Q., Butterfield D. A., Schulte M., Kelley D. S. and Lilley M. D. (2010) Elevated concentrations of formate, acetate and dissolved organic carbon found at the Lost City hydrothermal field. Geochim. Cosmochim. Acta 74, 941-952.

Lu W., Chou I. M., Burruss R. C. and Song Y. (2007) A unified equation for calculating methane vapor pressures in the $\mathrm{CH}_{4}-\mathrm{H}_{2} \mathrm{O}$ system with measured Raman shifts. Geochim. Cosmochim. Acta 71, 3969-3978.

Malcolm F. L. (1979) Petrography, mineral chemistry and microstructures of gabbros from the Mid-Cayman Rise spreading center. M.S. thesis, State University of New York at Albany.

Manning C. E., MacLeod C. J. and Weston P. E. (2000) Lower-crustal cracking front at fastspreading ridges: Evidence from the East Pacific Rise and the Oman ophiolite. In Ophiolites and oceanic crust: New insights from field studies and the Ocean Drilling Program (eds. Y. Dilek, E. M. Moores, D. Elthon, and A. Nicolas). Geological Society of America Special Paper 349, Boulder, CO. pp. 261-272.

Marty B. and Tolstikhin I. N. (1998) $\mathrm{CO}_{2}$ fluxes from mid-ocean ridges, arcs and plumes. Chem. Geol. 145, 233-248.

Mathez E. A. (1987) Carbonaceous matter in mantle xenoliths: Composition and relevance to the 
isotopes. Geochim. Cosmochim. Acta 51, 2339-2347.

Mathez E. A. and Delaney J. R. (1981) The nature and distribution of carbon in submarine basalts and peridotite nodules. Earth Planet. Sci. Lett. 56, 217-232.

McCollom T. M. (2008) Observational, experimental, and theoretical constraints on carbon cycling in mid-ocean ridge hydrothermal systems. In Magma to Microbe: Modeling Hydrothermal Processes at Ocean Spreading Centers (eds. R. P. Lowell, J. S. Seewald, A. Metaxas, and M. R. Perfit). American Geophysical Union, Washington, D. C. pp. 193-213. McCollom T. M. (2016) Abiotic methane formation during experimental serpentinization of olivine. Proc. Natl. Acad. Sci. 113, 13,965-13,970.

McCollom T. M. and Seewald J. S. (2001) A reassessment of the potential for reduction of dissolved $\mathrm{CO}_{2}$ to hydrocarbons during serpentinization of olivine. Geochim. Cosmochim. Acta 65, 3769-3778.

McCollom T. M. and Seewald J. S. (2003) Experimental constraints on the hydrothermal reactivity of organic acids and acid anions: I. Formic acid and formate. Geochim. Cosmochim. Acta 67, 3625-3644.

McCollom T. M. and Seewald J. S. (2006) Carbon isotope composition of organic compounds produced by abiotic synthesis under hydrothermal conditions. Earth Planet. Sci. Lett. 243, $74-84$.

McCollom T. M. and Seewald J. S. (2007) Abiotic synthesis of organic compounds in deep-sea hydrothermal environments. Chem. Rev. 107, 382-401.

McCollom T. M. and Shock E. L. (1997) Geochemical constraints on chemolithoautotrophic metabolism by microorganisms in seafloor hydrothermal systems. Geochim. Cosmochim. Acta 61, 4375-4391.

McCollom T. M., Klein F., Robbins M., Moskowitz B., Berquó T. S., Jöns N., Bach W. and Templeton A. (2016) Temperature trends for reaction rates, hydrogen generation, and partitioning of iron during experimental serpentinization of olivine. Geochim. Cosmochim. Acta 181, 175-200.

McDermott J. M., Seewald J. S., German C. R. and Sylva S. P. (2015) Pathways for abiotic organic synthesis at submarine hydrothermal fields. Proc. Natl. Acad. Sci. 112, 7668-7672.

Merlivat L., Pineau F. and Javoy M. (1987) Hydrothermal vent waters at $13^{\circ} \mathrm{N}$ on the East Pacific Rise: Isotopic compostion and gas concentration. Earth Planet. Sci. Lett. 84, 100108.

Miller H. M., Matter J. M., Kelemen P., Ellison E. T., Conrad M. E., Fierer N., Ruchala T., Tominaga M. and Templeton A. S. (2016) Modern water/rock reactions in Oman hyperalkaline peridotite aquifers and implications for microbial habitability. Geochim. Cosmochim. Acta 179, 217-241.

Mottl M. J., Seewald J. S., Wheat C. G., Tivey M. K., Michael P. J., Proskurowski G., Mccollom T. M., Reeves E., Sharkey J., You C.-F., Chan L.-H. and Pichler T. (2011) Chemistry of hot springs along the Eastern Lau Spreading Center. Geochim. Cosmochim. Acta 75, 10131038.

Norman D. I. and Sawkins F. J. (1987) Analysis of volatiles in fluid inclusions by mass spectrometry. Chem. Geol. 61, 1-10.

Norman D. I., Harrison R. W. and Andres C. B. (1991) Geology and geochemical analysis of mineralizing fluids at the St. Cloud and U.S. Treasury Mines, Chloride Mining District, New Mexico. J. Geochemical Explor. 42, 61-89.

Pineau F. and Mathez E. A. (1990) Carbon isotopes in xenoliths from the Hualalai Volcano, 
Hawaii, and the generation of isotopic variability. Geochim. Cosmochim. Acta 54, 217-227.

Piperov N. B. and Penchev N. P. (1973) A study on gas inclusions in minerals. Analysis of the gases from micro-inclusions in allanite. Geochim. Cosmochim. Acta 37, 2075-2097.

Proskurowski G., Lilley M. D., Kelley D. S. and Olson E. J. (2006) Low temperature volatile production at the Lost City Hydrothermal Field, evidence from a hydrogen stable isotope geothermometer. Chem. Geol. 229, 331-343.

Proskurowski G., Lilley M. D., Seewald J. S., Früh-Green G. L., Olson E. J., Lupton J. E., Sylva S. P. and Kelley D. S. (2008) Abiogenic hydrocarbon production at Lost City Hydrothermal Field. Science 319, 604-607.

Reeves E. P., Seewald J. S., Saccocia P., Bach W., Craddock P. R., Shanks W. C., Sylva S. P., Walsh E., Pichler T. and Rosner M. (2011) Geochemistry of hydrothermal fluids from the PACMANUS, Northeast Pual and Vienna Woods hydrothermal fields, Manus Basin, Papua New Guinea. Geochim. Cosmochim. Acta 75, 1088-1123.

Roedder E. (1972) Composition of fluid inclusions. U.S. Geol. Surv. Prof. Pap. 440 JJ, 164 pp.

Roedder E. (1984) Fluid Inclusions. Reviews in Mineralogy, Vol. 12. Mineralogical Society of America, Washington, D. C. 644 pp.

Rosso K. M. and Bodnar R. J. (1995) Microthermometric and Raman spectroscopic detection limits of $\mathrm{CO}_{2}$ in fluid inclusions and the Raman spectroscopic characterization of $\mathrm{CO}_{2}$. Geochim. Cosmochim. Acta 59, 3961-3975.

Sakai H., Des Marais D. J., Ueda A. and Moore J. G. (1984) Concentrations and isotope ratios of carbon, nitrogen and sulfur in ocean-floor basalts. Geochim. Cosmochim. Acta 48, 24332441.

Salvi S. and Williams-Jones A. E. (2003) Bulk analysis of volatiles in fluid inclusions. Mineralogical Association of Canada, Short Course Series 32, 247-278.

Sanford R. F. (1981) Mineralogical and chemical effects of hydration reactions and applications to serpentinization. Am. Mineral. 66, 290-297.

Sano Y., Urabe A., Wakita H. and Wushiki H. (1993) Origin of hydrogen-nitrogen gas seeps, Oman. Appl. Geochemistry 8, 1-8.

Schmidt K., Koschinsky A., Garbe-Schönberg D., de Carvalho L. M. and Seifert R. (2007) Geochemistry of hydrothermal fluids from the ultramafic-hosted Logatchev hydrothermal field, $15^{\circ} \mathrm{N}$ on the Mid-Atlantic Ridge: Temporal and spatial investigation. Chem. Geol. 242, 1-21.

Schroeder T., Bach W., Jöns N., Jöns S., Monien P. and Klügel A. (2015) Fluid circulation and carbonate vein precipitation in the footwall of an oceanic core complex, Ocean Drilling Program Site 175, Mid-Atlantic Ridge. Geochemistry, Geophys. Geosystems 16, 37163732.

Schwartz J. J., John B. E., Cheadle M. J., Reiners P. W. and Baines A. G. (2009) Cooling history of Atlantis Bank oceanic core complex: Evidence for hydrothermal activity 2.6 Ma off axis. Geochemistry, Geophys. Geosystems 10, Q08020, doi:10.1029/2009GC002466.

Schwarzenbach E. M., Früh-Green G. L., Bernasconi S. M., Alt J. C. and Plas A. (2013) Serpentinization and carbon sequestration: A study of two ancient peridotite-hosted hydrothermal systems. Chem. Geol. 351, 115-133.

Seewald J. S. (2001) Aqueous geochemistry of low molecular weight hydrocarbons at elevated temperatures and pressures: Constraints from mineral buffered laboratory experiments. Geochim. Cosmochim. Acta 65, 1641-1664.

Seewald J. S., Cruse A. M. and Saccocia P. (2003) Aqueous volatiles in hydrothermal fluids 
from the Main Endeavour Field, northern Juan de Fuca Ridge: Temporal variability following earthquake activity. Earth Planet. Sci. Lett. 216, 575-590.

Seewald J. S., Zolotov M. Y. and McCollom T. (2006) Experimental investigation of single carbon compounds under hydrothermal conditions. Geochim. Cosmochim. Acta 70, 446460.

Seyfried W. E., Pester N. J., Ding K. and Rough M. (2011) Vent fluid chemistry of the Rainbow hydrothermal system $\left(36^{\circ} \mathrm{N}, \mathrm{MAR}\right)$ : Phase equilibria and in situ $\mathrm{pH}$ controls on subseafloor alteration processes. Geochim. Cosmochim. Acta 75, 1574-1593.

Seyfried W. E., Pester N. J., Tutolo B. M. and Ding K. (2015) The Lost City hydrothermal system: Constraints imposed by vent fluid chemistry and reaction path models on subseafloor heat and mass transfer processes. Geochim. Cosmochim. Acta 163, 59-79.

Shilobreeva S., Martinez I., Busigny V., Agrinier P. and Laverne C. (2011) Insights into C and H storage in the altered oceanic crust: Results from ODP/IODP Hole 1256D. Geochim. Cosmochim. Acta 75, 2237-2255.

Shock E. L. (1990) Geochemical constraints on the origin of organic compounds in hydrothermal systems. Orig. Life Evol. Biosph. 20,331-367.

Spivack A. J. and Edmond J. M. (1987) Boron isotope exchange between seawater and the oceanic crust. Geochim. Cosmochim. Acta 51, 1033-1043.

Stroup J. B. and Fox P. J. (1981) Geologic investigations in the Cayman Trough: Evidence for thin oceanic crust along the Mid-Cayman Rise. J. Geol. 89, 395-420.

Sturchio N. C., Abrajano T. A., Murowchick J. B. and Muehlenbachs K. (1989) Serpentinization of the Acoje massif, Zambales ophiolite, Philippines: Hydrogen and oxygen isotope geochemistry. Tectonophysics 168, 101-107.

Sugisaki R. and Mimura K. (1994) Mantle hydrocarbons: Abiotic or biotic? Geochim. Cosmochim. Acta 58, 2527-2542.

Takai K., Gamo T., Tsunogai U., Nakayama N., Hirayama H., Nealson K. H. and Horikoshi K. (2004) Geochemical and microbiological evidence for a hydrogen-based, hyperthermophilic subsurface lithoautotrophic microbial ecosystem (HyperSLiME) beneath an active deep-sea hydrothermal field. Extremophiles 8, 269-282.

Takenouchi S. and Kennedy G. C. (1965) The solubility of carbon dioxide in $\mathrm{NaCl}$ solutions at high temperatures and pressures. Am. J. Sci. 263, 445-454.

Tingle T. N., Hochella M. F., Becker C. H. and Malhotra R. (1990) Organic compounds on crack surfaces in olivine from San Carlos, Arizona and Hualalai Volcano, Hawaii. Geochim. Cosmochim. Acta 54, 477-485.

Tingle T. N., Mathez E. A. and Hochella Jr. M. F. (1991) Carbonaceous matter in peridotites and basalts studied by XPS, SALI, and LEED. Geochim. Cosmochim. Acta 55, 1345-1352.

Von Damm K. L., Edmond J. M., Grant B., Measures C. I., Walden B. and Weiss R. F. (1985) Chemistry of submarine hydrothermal solutions at $21^{\circ} \mathrm{N}$, East Pacific Rise. Geochim. Cosmochim. Acta 49, 2197-2220.

Wang D. T., Reeves E. P., McDermott J. M., Seewald J. S. and Ono S. (2017) Clumped isotopologue constraints on the origin of methane at seafloor hot springs. Geochim. Cosmochim. Acta, doi: https://doi.org/10.1016/j.gca.2017.11.030.

Welhan J. A. (1988) Methane and hydrogen in mid-ocean-ridge basalt glasses: Analysis by vacuum crushing. Can. J. Earth Sci. 25, 38-48.

Welhan J. A. and Craig H. (1983) Methane, hydrogen and helium in hydrothermal fluids at $21^{\circ} \mathrm{N}$ on the East Pacific Rise. In Hydrothermal Processes at Seafloor Spreading Centers (eds. P. 
A. Rona, K. Boström, L. Laubier, and K. L. Smith). Springer, Boston, MA. pp. 391-409. Wopenka B. and Pasteris J. D. (1987) Raman intensities and detection limits of geochemically relevant gas mixtures for a laser Raman microprobe. Anal. Chem. 59, 2165-2170.

Zhang J., Qiao S., Lu W., Hu Q., Chen S. and Liu Y. (2016) An equation for determining methane densities in fluid inclusions with Raman shifts. J. Geochemical Explor. 171, 20 28. 


\section{Chapter 5}

\section{Conclusions and future research directions}

This thesis examines carbon and mineral reaction pathways in ultramafic-influenced hydrothermal systems and their role in influencing the speciation and distribution of carbon in the oceanic lithosphere. This chapter briefly summarizes the main conclusions of each chapter and outlines potential future research directions.

CHAPTERS 2 and 3 demonstrate that carbonate formation is favorable even at high $\mathrm{H}_{2 \text { (aq) }}$ concentrations produced during hydrothermal alteration of peridotite at $200-300^{\circ} \mathrm{C}$. Experimental results indicate that carbonation pathways are affected by a number of factors, including temperature, fluid composition (e.g., $\mathrm{Mg} / \mathrm{Ca}$ activity ratio), the relative abundance of primary and secondary minerals, and the composition of the secondary mineral assemblage, suggesting that there are no unique carbonation pathways in serpentinization systems. Although measurable quantities of formate were formed on laboratory time scales, they remained low due to the sequestration of dissolved inorganic carbon in carbonate minerals. Despite the strongly reducing conditions generated by serpentinization reactions, kinetic barriers prevented $\mathrm{CH}_{4(a q)}$ from attaining stable equilibrium with $\mathrm{CO}_{2(a q)}$ on laboratory time scales. These results are consistent with previous experimental and field studies that have documented prohibitively slow rates of $\mathrm{CO}_{2}$ reduction to $\mathrm{CH}_{4}$ under hydrothermal conditions and in the absence of specific catalysts (McCollom and Seewald, 2001; McCollom and Seewald, 2003; Foustoukos and Seyfried, 2004; Seewald et al., 2006; Fu et al., 2007; McDermott et al., 2015; McCollom, 2016). Constraints from radionuclides indicate that crustal residence times of high-temperature $\left(>200^{\circ} \mathrm{C}\right)$ fluids in mid-ocean ridge hydrothermal systems are $\leq 3-10$ years (Kadko and Moore, 1988; Kadko and Butterfield, 1998). Thus, it is unlikely that there is sufficient time for $\mathrm{CO}_{2(a q)}$ to attain equilibrium with $\mathrm{CH}_{4(a q)}$ and generate significant quantities of hydrocarbons in seafloor hydrothermal fluids. Longer reaction times may potentially be achieved in fluid inclusions, which can trap magmatic $\mathrm{CO}_{2}$ in subsurface rocks on geologic time scales, prior to their extraction by circulating fluids (Kelley, 1996; Kelley and Früh-Green, 1999). 
As discussed in CHAPTER 3, fundamental questions remain regarding the relative stabilities of carbon compounds on the long time scales encountered in mineral-hosted inclusions. Thermodynamic models are, therefore, necessary to evaluate how temperature, protolith composition, fluid chemistry, and $\mathrm{W} / \mathrm{R}$ ratio regulate carbon speciation during peridotite- $\mathrm{CO}_{2}$ interactions. In particular, future models should expand on those of Hentscher (2012) to assess how dissolved $\mathrm{CO}_{2}$ concentrations affect the thermodynamic stabilities of $\mathrm{CH}_{4}$ and carbonate minerals at redox conditions predicted for serpentinization of peridotite.

CHAPTER 4 demonstrates that olivine-rich rocks from the Mid-Cayman Rise and the Zambales ophiolite contain significant quantities of $\mathrm{CH}_{4}$ and $\mathrm{C}_{2} \mathrm{H}_{6}$ hosted in fluid inclusions. $\delta^{13} \mathrm{C}$ compositions of hydrocarbons in whole rock samples are similar to the range in carbon isotopic compositions not only in associated vent fluids, but also other ultramafic-influenced hydrothermal fluids. This suggests that leaching of fluid inclusions may provide a significant contribution of abiotic hydrocarbons to both seafloor and continental serpentinization systems. However, more samples need to be analyzed to better characterize the range in hydrocarbon compositions for a particular rock type, including peridotite, dunite, troctolite, and olivine-rich gabbroic rocks.

The findings of CHAPTER 4 can be further expanded by analyzing fluid inclusions in other ultramafic-influenced vent sites, including the Lost City and Logatchev hydrothermal fields. Olivine-rich rocks from other ultramafic exposures, including Hess Deep, the Mid-Atlantic Ridge $15^{\circ} 20$ fracture zone, and Mid-Atlantic Ridge south of the Kane Fracture Zone (MARK area), can also be examined to assess the range in hydrocarbon isotope signatures in a variety of seafloor environments. Comparisons of hydrocarbon abundances and isotopic compositions from different oceanic settings may potentially reveal systematic trends with inferred subsurface conditions (e.g., temperature, pressure). Hydrocarbon concentrations measured at ambient conditions, however, do not necessarily reflect their equilibrium distributions at elevated temperatures and pressures encountered since entrapment. Since carbon compounds respeciate as temperatures and pressures decrease during crustal exhumation, thermodynamic modeling is necessary to reconstruct relative hydrocarbon abundances under conditions prevailing in hydrothermal reaction zones. For instance, equilibrium $\mathrm{CH}_{4} / \mathrm{C}_{2} \mathrm{H}_{6}$ ratios can be modeled during heating of the host rock and compared with measured ratios in Von Damm vent fluids to estimate the temperature at which hydrocarbon gases last equilibrated. In addition to chemical 
respeciation occurring within the fluid phase, reactions have also likely taken place between entrapped volatiles and their mineral host, as indicated by the presence of secondary minerals lining the walls of fluid inclusions. Thermodynamic models can also be conducted to assess the range in initial fluid compositions and $\mathrm{W} / \mathrm{R}$ mass ratios needed to produce the observed volatile and mineral contents of secondary inclusions. 


\section{REFERENCES}

Foustoukos D. I. and Seyfried W. E. J. (2004) Hydrocarbons in hydrothermal vent fluids: The role of chromium-bearing catalysts. Science 304, 1002-1005.

Fu Q., Sherwood Lollar B., Horita J., Lacrampe-Couloume G. and Seyfried W. E. J. (2007) Abiotic formation of hydrocarbons under hydrothermal conditions: Constraints from chemical and isotope data. Geochim. Cosmochim. Acta 71, 1982-1998.

Hentscher M. (2012) Thermodynamic investigations of microbial metabolism and abiotic organic synthesis in seafloor hydrothermal systems. Ph.D. thesis, University of Bremen.

Kadko D. and Butterfield D. A. (1998) The relationship of hydrothermal fluid composition and crustal residence time to maturity of vent fields on the Juan de Fuca Ridge. Geochim. Cosmochim. Acta 62, 1521-1533.

Kadko D. and Moore W. (1988) Radiochemical constraints on the crustal residence time of submarine hydrothermal fluids: Endeavor Ridge. Geochim. Cosmochim. Acta 52, 659-668.

Kelley D. S. (1996) Methane-rich fluids in the oceanic crust. J. Geophys. Res. Earth 101, 29432962.

Kelley D. S. and Früh-Green G. L. (1999) Abiogenic methane in deep-seated mid-ocean ridge environments: Insights from stable isotope analyses. J. Geophys. Res. 104, 10,439-10,460.

McCollom T. M. (2016) Abiotic methane formation during experimental serpentinization of olivine. Proc. Natl. Acad. Sci. 113, 13,965-13,970.

McCollom T. M. and Seewald J. S. (2001) A reassessment of the potential for reduction of dissolved $\mathrm{CO}_{2}$ to hydrocarbons during serpentinization of olivine. Geochim. Cosmochim. Acta 65, 3769-3778.

McCollom T. M. and Seewald J. S. (2003) Experimental constraints on the hydrothermal reactivity of organic acids and acid anions: I. Formic acid and formate. Geochim. Cosmochim. Acta 67, 3625-3644.

McDermott J. M., Seewald J. S., German C. R. and Sylva S. P. (2015) Pathways for abiotic organic synthesis at submarine hydrothermal fields. Proc. Natl. Acad. Sci. 112, 7668-7672.

Seewald J. S., Zolotov M. Y. and McCollom T. (2006) Experimental investigation of single carbon compounds under hydrothermal conditions. Geochim. Cosmochim. Acta 70, 446460 . 